IMPACT OF GEOTHERMAL TECHNOLOGY IMPROVEMENTS ON ROYALTY COLLECTIONS ON FEDERAL LAND

\title{
VOLUME II - APPENDICES
}

October 1988

SAN FRANCISCO OPERATIONS OFFICE U.S. DEPARTMENT OF ENERGY

\section{DO NOT MICROFILM COVER}



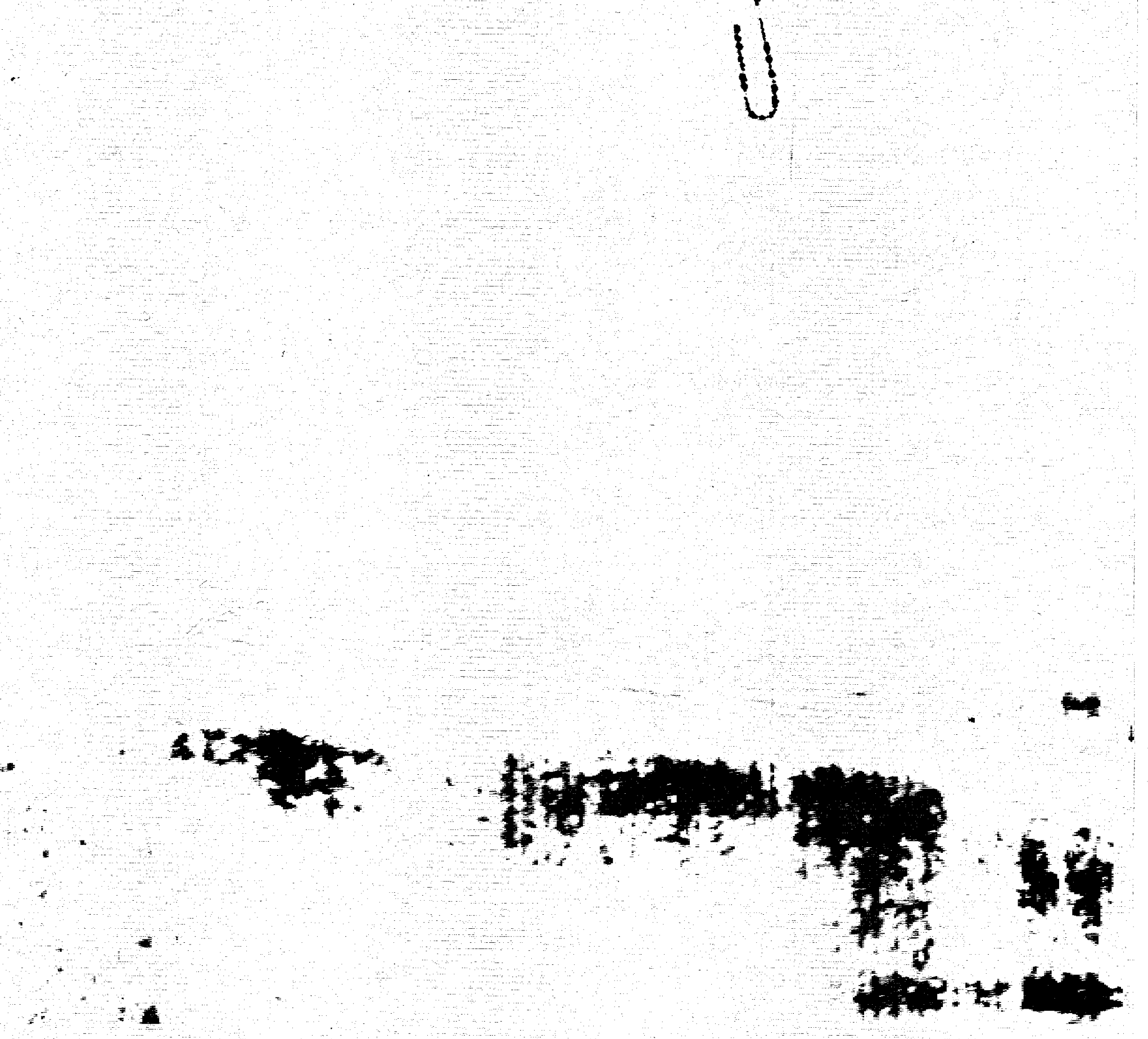


\section{DISCLAIMER}

This report was prepared as an account of work sponsored by an agency of the United States Government. Neither the United States Government nor any agency Thereof, nor any of their employees, makes any warranty, express or implied, or assumes any legal liability or responsibility for the accuracy, completeness, or usefulness of any information, apparatus, product, or process disclosed, or represents that its use would not infringe privately owned rights. Reference herein to any specific commercial product, process, or service by trade name, trademark, manufacturer, or otherwise does not necessarily constitute or imply its endorsement, recommendation, or favoring by the United States Government or any agency thereof. The views and opinions of authors expressed herein do not necessarily state or reflect those of the United States Government or any agency thereof. 


\section{DISCLAIMER}

Portions of this document may be illegible in electronic image products. Images are produced from the best available original document. 


$$
\text { DOE/SF//6299- T10 }
$$

\section{IMPACT OF GEOTHERMAL TECHNOLOGY IMPROVEMENTS ON ROYALTY COLLECTIONS ON FEDERAL LANDS}

VOLUME II - APPENDICES DOE/SF/16299--T10

DE89 004416

Prepared for the

San Francisco Operations Office: U.S. Department of Energy Contract No.DE-AC03-86SF-16299

Meridian CORPORATION ALEXANDRIA, VIRGINIA

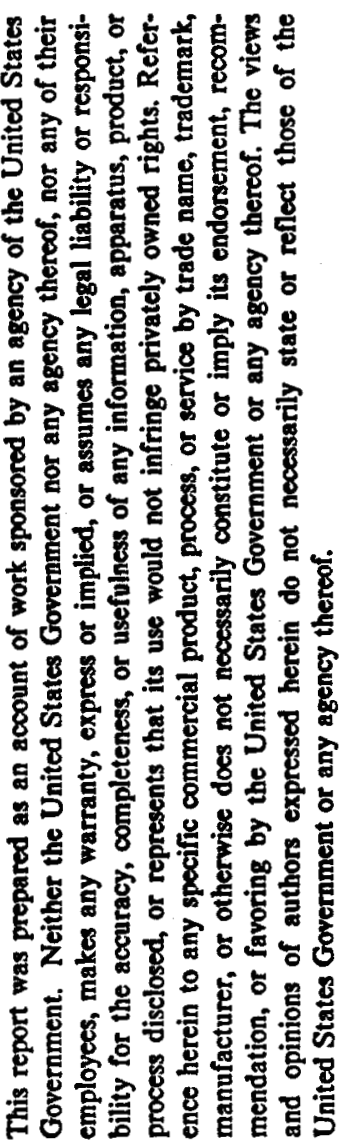

OCtOBER 1988

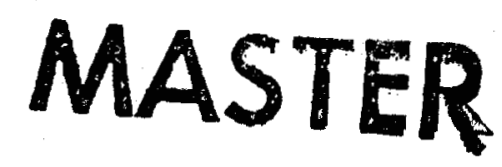




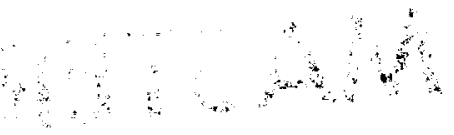




\section{PREFACE}

This volume contains the appendices for the "Impact of Geothermal Technology Improvements on Royalty Collections on Federal Lands - Final Report Volume I." The material in this volume supports the conclusions presented in Volume I and details each Known Geothermal Resource Area's (KGRA's) royalty estimation.

Appendix A details the physical characteristics of each KGRA considered in Volume I. Appendix B supplies summary narratives on each state which has a KGRA.

The information presented in Appendix $C$ shows the geothermal power plant area proxies chosen for each KGRA considered within the report. It also provides data ranges which fit into the IMGEO model for electric energy cost estimates.

Appendix $D$ provides detalled cost information from the IMGEO model if a.) no Geothermal Program R\&D goals were completed beyond 1987, and b.) if all the R\&D goals were completed by the year 2000. This appendix gives an overall electric cost and major system costs, which add up to the overall electric cost.

Appendix E supplies information for avoided cost projections for each state involved in the study that were used in the IMGEO model run to determine at what cost/kWh a 50 MWe plant could come on line.

Appendix $F$ supplies the code used in the determination of royalty income, as well as, tabled results of the royalty runs (detailed in Appendix $G$ ). The tabled results show royalty incomes, assuming a $10 \%$ discount rate, with and without R\&D and with and without a $\$ 0.01 / \mathrm{kWh}$ transmission cost. Individual data sheets for each KGRA royalty income run are presented in Appendix G. 
APPENDIX A

SUIYARY OF KGRA PROFILES

$$
A-1 / A-2
$$



BLM - Bureau of Land Management

BLM VRM - BLM Visual Resource Management Class

Class I: This class provides primarily for natural ecological changes only. It is applied to primitive areas, some natural areas, and other similar situations where management activities are to be restricted.

Class II: Changes in any of the basic elements (form, line, color or texture) caused by a management of activity should not be evident in the characteristic landscape.

Class III: Changes in the basic elements (form, line, color, or texture caused by a management activity may be evident in the characteristic landscape. However, the changes should remain subordinate to the visual strength of the existing character.

Class IV: Changes may subordinate the original composition and character but must reflect what could be a natural occurrence within the characteristic landscape.

Class V: Change is needed. This class applies to areas where the naturalistic character has been disturbed to a point where rehabilitation is needed to bring it back into character with the surrounding countryside. This class would apply to areas identified in the scenery evaluation where the quality class has been reduced because of unacceptable intrusions. It should be considered an interim short term classification until one of the other objectives can be reached through rehabilitation or enhancement. The desired visual quality objective should be identified.

A proposed surface disturbing project can then be analyzed for its usual impacts on the landscape in terms of form, line, color and texture and determine whether or not it will be an "eyesore."

C - Competitive lease(s)

CI - Competitive interest; this means that the KGRA was designated only because the acreage applied for in two or more noncompetitive lease applications overlapped by at least 50 percent.

DOGAMI - Oregon Department of Geology and Mineral Industries

GC - Geologic criteria; this means that the KGRA was designated on the basis that USGS feels that there are geologic indications of commercial resource

NC - Noncompetitive lease(s)

Rel. - Relinquished

Term. - Terminated

WSA - Wilderness Study Area 


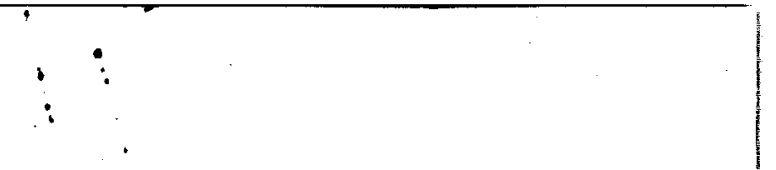




\section{Arremolx A}

SIIWARY OF KGRA PROFILES

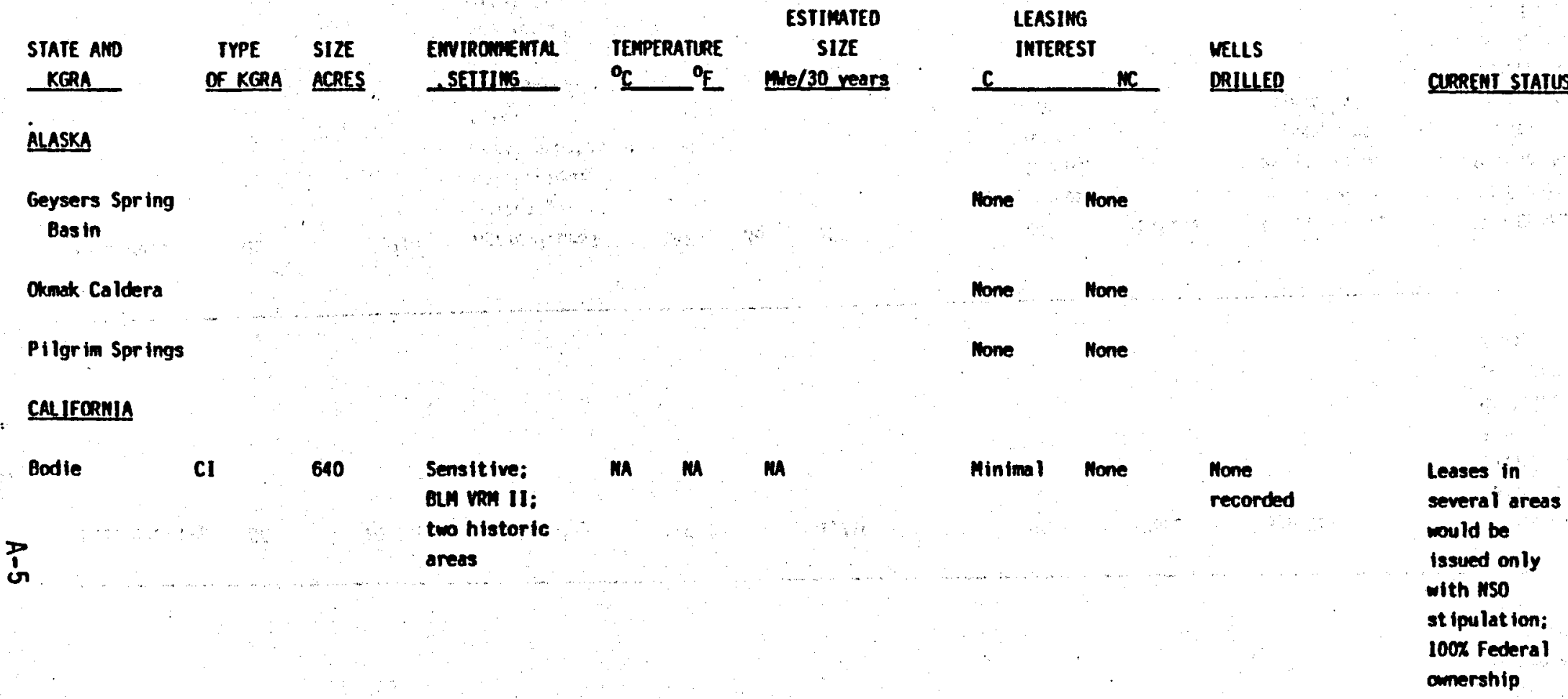

\begin{tabular}{|c|c|c|c|c|c|c|c|c|c|c|}
\hline Brauley & GC & 28,885 & $\begin{array}{l}\text { No scenlc } \\
\text { quality; some } \\
\text { areas unsultable } \\
\text { for faming }\end{array}$ & 250 & 487 & 1710 & See "Current & $\begin{array}{c}\text { Status" } \\
:\end{array}$ & Full deve lopm=nt & $\begin{array}{l}\text { 100k private } \\
\text { land; } 10 \text { mike } \\
\text { plant } \\
\text { dismant led }\end{array}$ \\
\hline
\end{tabular}

Calistoga Cl $\quad 9.055 \quad$ SEE THE GEYSERS

\begin{tabular}{|c|c|c|c|c|c|c|c|c|c|c|c|}
\hline Coso HS & $C 1 / 6 C$ & 106.752 & $\begin{array}{l}\text { High desert } \\
\text { environment; air } \\
\text { quality typical } \\
\text { of nonindustrial } \\
\text { Upper Majove } \\
\text { Desert }\end{array}$ & 230 & 446 & 650 & $20^{+}$ & $\begin{array}{l}\text { Little; } \\
\text { leases } \\
\text { issued } \\
\text { still } \\
\text { act ive }\end{array}$ & Full deve lopment & $\begin{array}{l}30 \text { me } \\
\text { California } \\
\text { Energy Co. } \\
\text { plant on line: } \\
2 \text { addit ional } \\
67.5 \text { mite } \\
\text { plants }\end{array}$ & $\begin{array}{l}\text { planned: Los } \\
\text { Angeles Dept. } \\
\text { of Water and } \\
\text { Power plans } 10 \\
\text { We plant for } \\
1990 \text {. }\end{array}$ \\
\hline
\end{tabular}




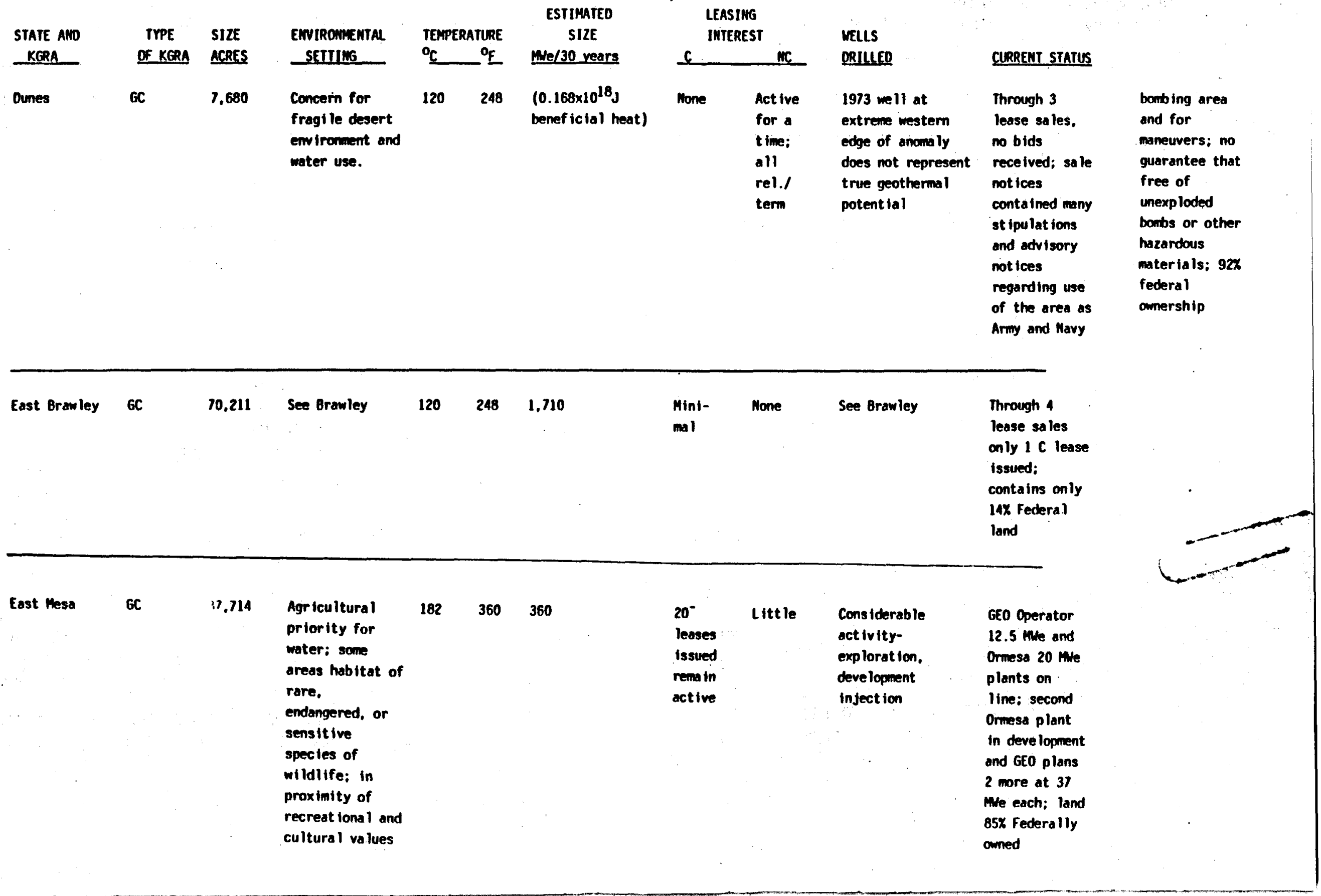




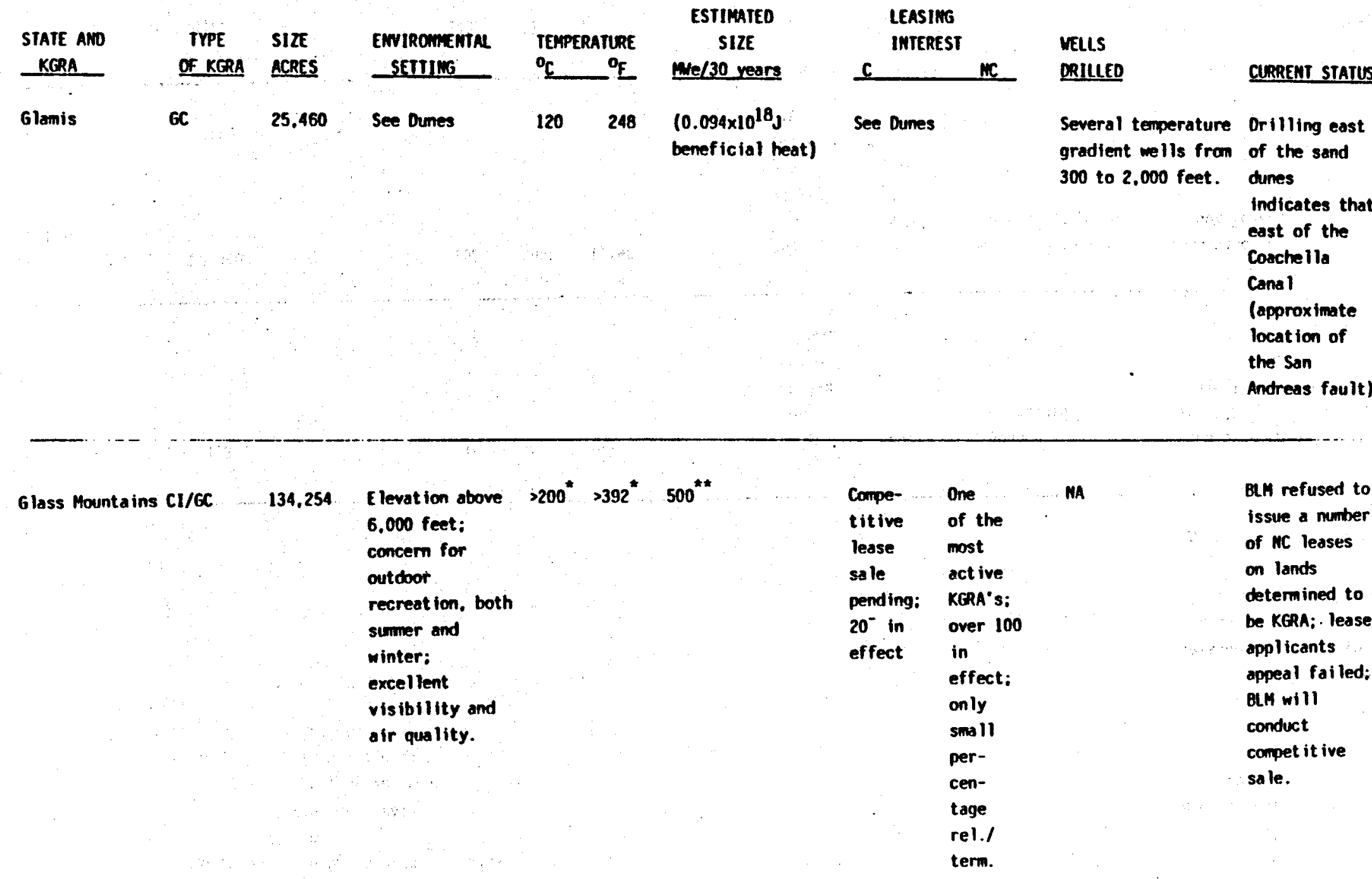

- Mitre

** Est imate from Forest Service Environmental Assessment 


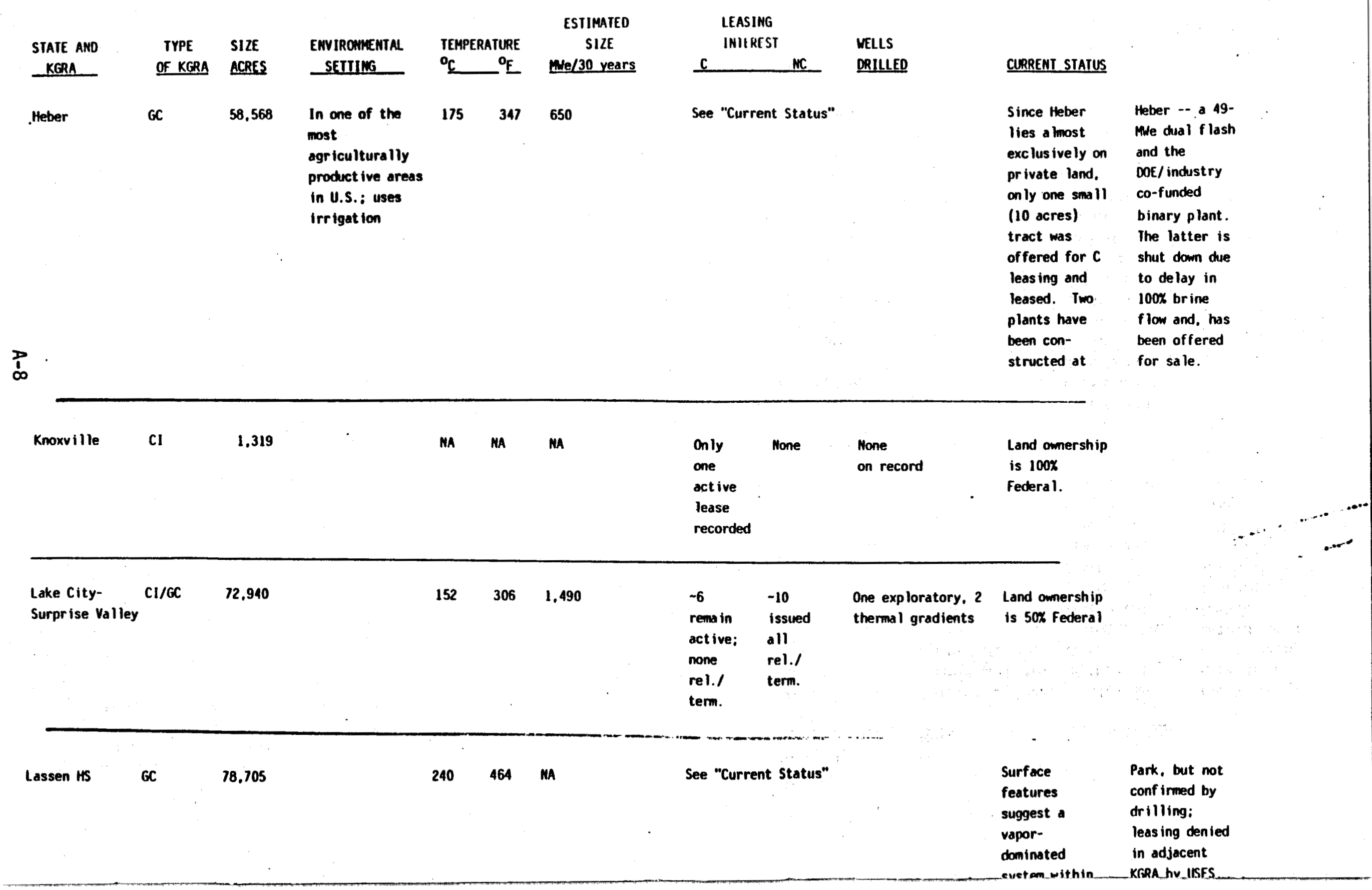




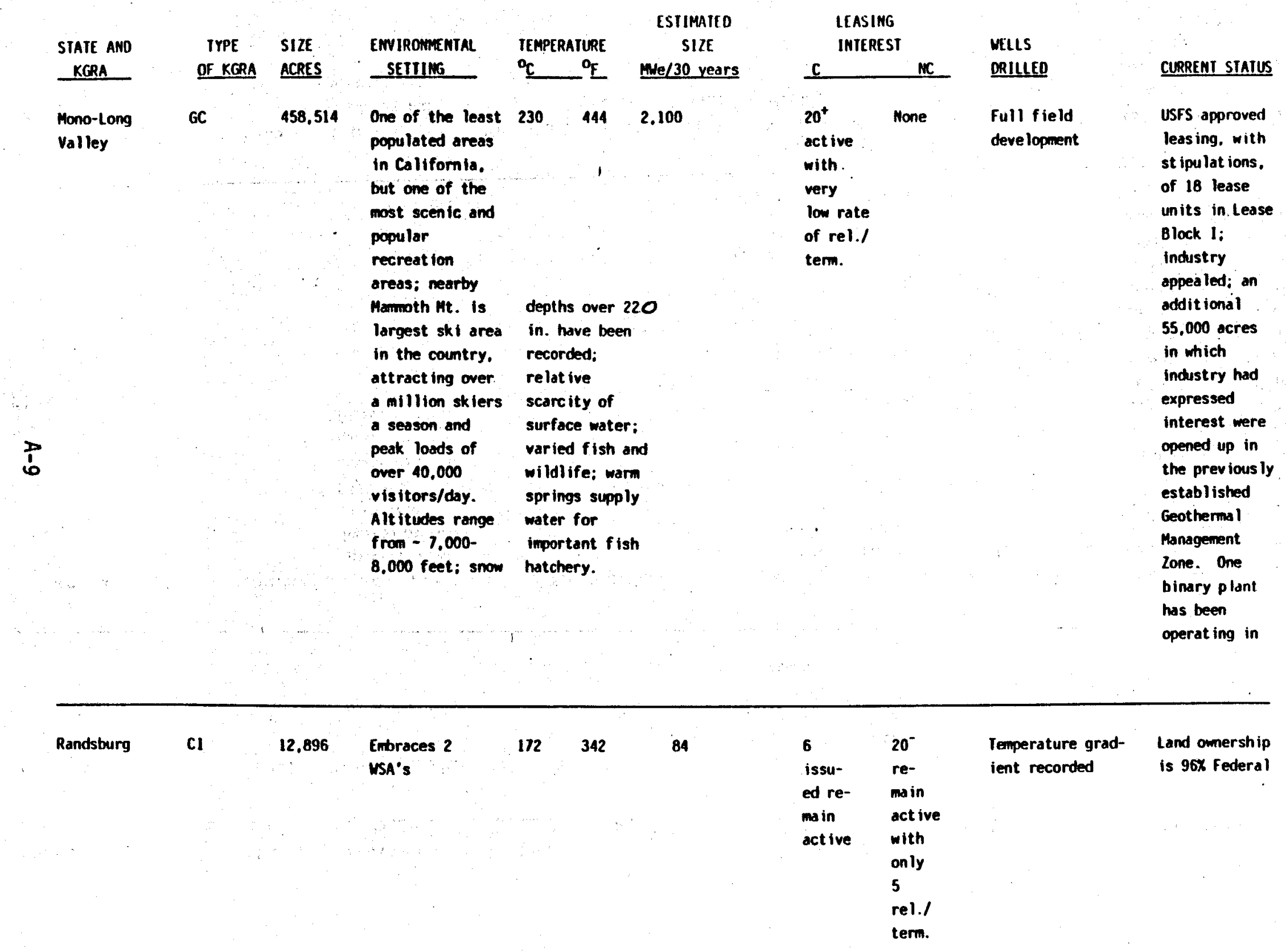




\begin{tabular}{|c|c|c|c|c|c|c|c|c|c|c|c|}
\hline \multirow{2}{*}{$\begin{array}{l}\text { STATE ANO } \\
\text { KGRA } \\
\text { Saline Valley }\end{array}$} & \multirow{3}{*}{$\begin{array}{l}\text { IYPE } \\
\text { OF } * \text { RA } \\
\text { CI }\end{array}$} & \multirow{3}{*}{$\begin{array}{l}\text { S1ZE } \\
\text { ACRES } \\
3,199\end{array}$} & \multirow{3}{*}{$\begin{array}{l}\text { ENVIROMMEMTAL } \\
\text { SEIIIMG } \\
\text { Embraces one USA }\end{array}$} & \multirow{2}{*}{\multicolumn{2}{|c|}{$\begin{array}{l}\text { TEMPERATURE } \\
{ }^{\circ} \mathrm{C} \quad{ }^{\circ} \mathrm{F}\end{array}$}} & \multirow{3}{*}{ 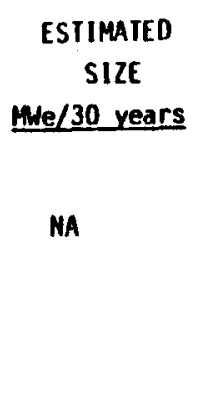 } & \multicolumn{2}{|c|}{$\begin{array}{l}\text { LEASING } \\
\text { IMIEREST }\end{array}$} & \multirow{3}{*}{$\begin{array}{l}\text { MELLS } \\
\text { DRILLED }\end{array}$} & \multirow[b]{2}{*}{ CURRENI STATUS } & \\
\hline & & & & & & & c & $M C$ & & & \\
\hline Saline Valley & & & & 57 & 133 & & $\begin{array}{l}\text { Mo } \\
\text { record } \\
\text { of } \\
\text { leas ing } \\
\text { found }\end{array}$ & $\begin{array}{l}\text { Mo } \\
\text { record } \\
\text { found }\end{array}$ & & $\begin{array}{l}\text { Land omnership } \\
\text { is } 100 \% \\
\text { Federal }\end{array}$ & \\
\hline Salton Sea & GC & 102,887 & $\begin{array}{l}5 \text { endangered } \\
\text { spieces; KGRA } \\
\text { located directly } \\
\text { on Pacif ic } \\
\text { Flyway; } \\
\text { extensive marsh } \\
\text { cover and mud } \\
\text { flats. }\end{array}$ & 330 & $\begin{array}{r}626 \\
.\end{array}$ & 3.100 & $\begin{array}{l}4 \\
\text { remain } \\
\text { act ive }\end{array}$ & $\begin{array}{l}5 \\
\text { remain } \\
\text { act ive }\end{array}$ & $\begin{array}{l}\text { Long history of } \\
\text { drilling }\end{array}$ & $\begin{array}{l}\text { Since the } \\
\text { deve lopment at } \\
\text { the Salton Sea } \\
\text { centers on } \\
\text { nonfederal } \\
\text { land around } \\
\text { its southern } \\
\text { tip, no } \\
\text { Federal } \\
\text { royalty is } \\
\text { foreseen unt } 11 \text {. } \\
\text { pattern } \\
\text { changes. One } \\
\text { lo mue } \\
\text { demonstrat iol. } \\
\text { plant, on line: }\end{array}$ & $\begin{array}{l}\text { since 1982. is } \\
\text { to be en larged } \\
\text { to } 30 \text { mie; a } \\
34 \text { me come } \\
\text { on-line in } \\
\text { 1985; another } \\
\text { is under } \\
\text { construct ion } \\
\text { to be followed } \\
\text { by two others. } \\
\text { all to cone } \\
\text { on-line in } \\
1988 / 89 \text {. A } \\
47.5 \text { mue plant } \\
\text { is a lso under } \\
\text { ronstruction. }\end{array}$ \\
\hline
\end{tabular}

$\begin{array}{lllllll}\text { Sespe HS } \quad \text { GC } \quad 7.035 \quad \begin{array}{l}\text { Extrenely } \\ \text { isolated and } \\ \text { undeveloped }\end{array} & 280 & 562 \quad \begin{array}{l}\left(0.062 \times 10^{18} \mathrm{~J}\right. \\ \text { beneficial heat })\end{array} & \begin{array}{l}\text { ho record of } \\ \text { leas ing. }\end{array}\end{array}$

A




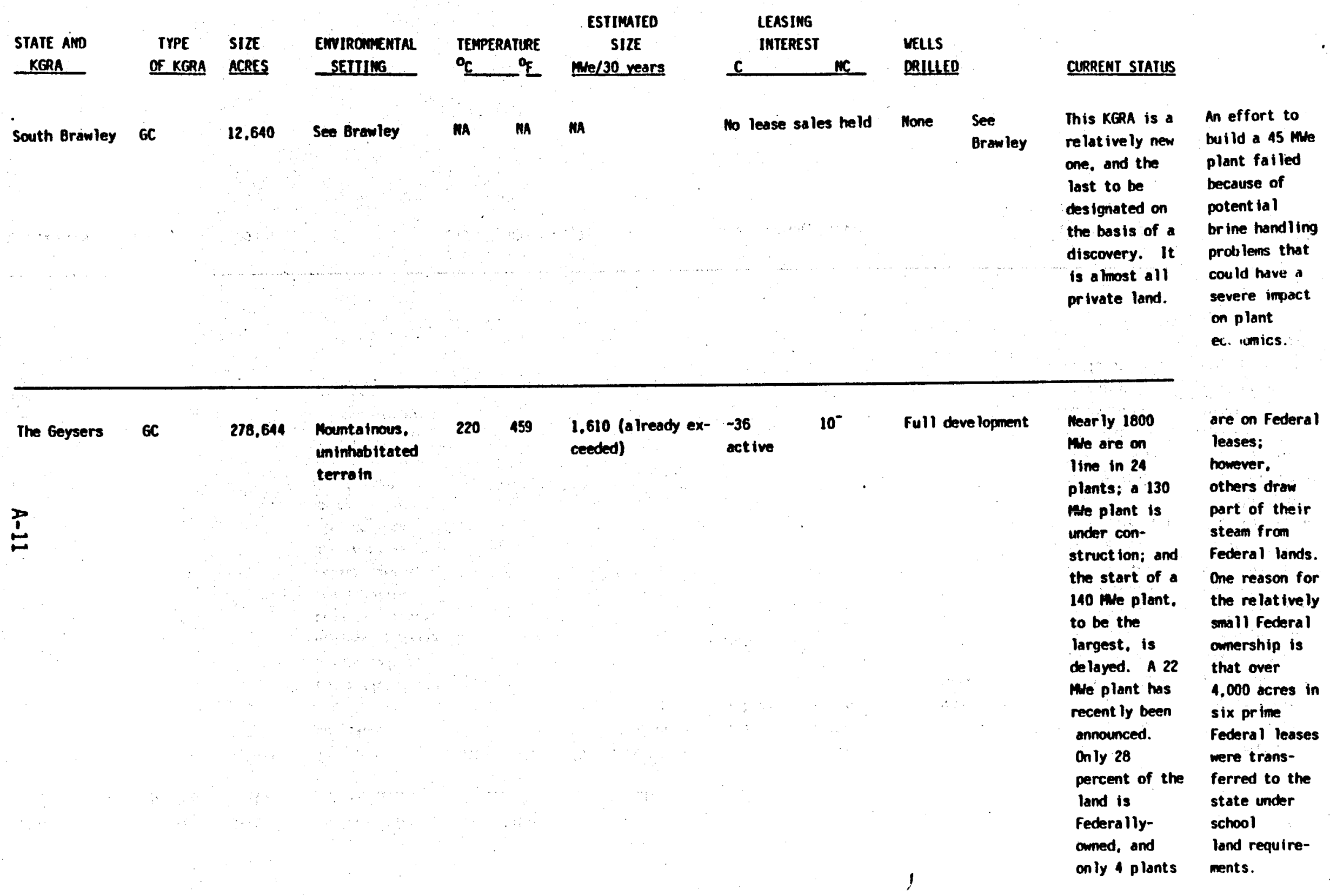




\begin{tabular}{|c|c|c|c|c|c|c|c|c|c|c|c|}
\hline $\begin{array}{l}\text { STAIE AND } \\
\text { KGRA }\end{array}$ & $\begin{array}{c}\text { TYPE } \\
\text { OF KGRA }\end{array}$ & $\begin{array}{l}\text { SIZE } \\
\text { ACRES }\end{array}$ & $\begin{array}{l}\text { ENVIRONHEHTAL } \\
\text { SETIIIG }\end{array}$ & $\begin{array}{l}\text { TEMP } \\
{ }^{\circ} \mathrm{C}\end{array}$ & $\begin{array}{l}\text { ITURE } \\
{ }^{O_{F}}\end{array}$ & $\begin{array}{c}\text { ESIIMATED } \\
\text { SIZE } \\
\text { Me/30 years }\end{array}$ & $\begin{array}{l}\text { LEASIM } \\
\text { INTERE } \\
\end{array}$ & & $\begin{array}{l}\text { WELLS } \\
\text { DRILLED }\end{array}$ & CURREMT STATUS & \\
\hline Wende I-Amedee & GC & 18.431 & $\begin{array}{l}\text { The area } \\
\text { containa } \\
\text { significant } \\
\text { recreat ional and } \\
\text { scenic values. } \\
\text { archeeo logically } \\
\text { sensit ive areas. } \\
\text { and wild ife } \\
\text { habitat areas. } \\
\text { but there is } \\
\text { a lso acreage } \\
\text { where } \\
\text { development } \\
\text { would not create } \\
\text { significant } \\
\text { residusi atverse } \\
\text { inpacts. }\end{array}$ & 128 & 262 & $\begin{array}{l}\left(0.190 \times 10^{18} \mathrm{~J}\right. \\
\text { beneficial heat) }\end{array}$ & $\begin{array}{l}1 \text { issued } \\
\text { and st } 111 \\
\text { active }\end{array}$ & $\begin{array}{l}2 \text { issued, } \\
1 \text { still } \\
\text { act ive }\end{array}$ & $\begin{array}{l}3 \text { prior to } 1982 \text { : } \\
3 \text { since, plus an } \\
\text { exp loratory well } \\
\text { for direct use }\end{array}$ & $\begin{array}{l}\text { In 1978, USGS } \\
\text { stated that } \\
\text { "Based on } \\
\text { avai lable data } \\
\text { and demon- } \\
\text { strated } \\
\text { technology. } \\
\text { the resource } \\
\text { at Wende I- } \\
\text { Amedee is } \\
\text { inadequate for } \\
\text { power } \\
\text { generat ion. } \\
\text { The tempera- } \\
\text { ture data } \\
\text { obta ined more } \\
\text { recent ly from } \\
\text { wells drilled }\end{array}$ & $\begin{array}{l}\text { to serve a } \\
\text { DOE-assisted } \\
\text { hybrid binary } \\
\text { plant at Honey } \\
\text { Lake tend to } \\
\text { validate this } \\
\text { assessment. } \\
\text { However, a } \\
\text { very sma } 11 \\
\text { binary unit. } \\
600 \text { kHe. is in } \\
\text { operat ion in } \\
\text { the area which } \\
\text { was economic } \\
\text { under site- } \\
\text { specif ic } \\
\text { condit ions; } \\
51 \% \text { of the } \\
\text { land Federal- } \\
\text { ly-omned. }\end{array}$ \\
\hline
\end{tabular}

$\begin{array}{rllllll}\text { Westmorland HA } & 3.200 & 215 & 418 & 1.710 & \text { See "Current Status" } & \text { Land is } 100 x \\ \text { nonfederal: }\end{array}$




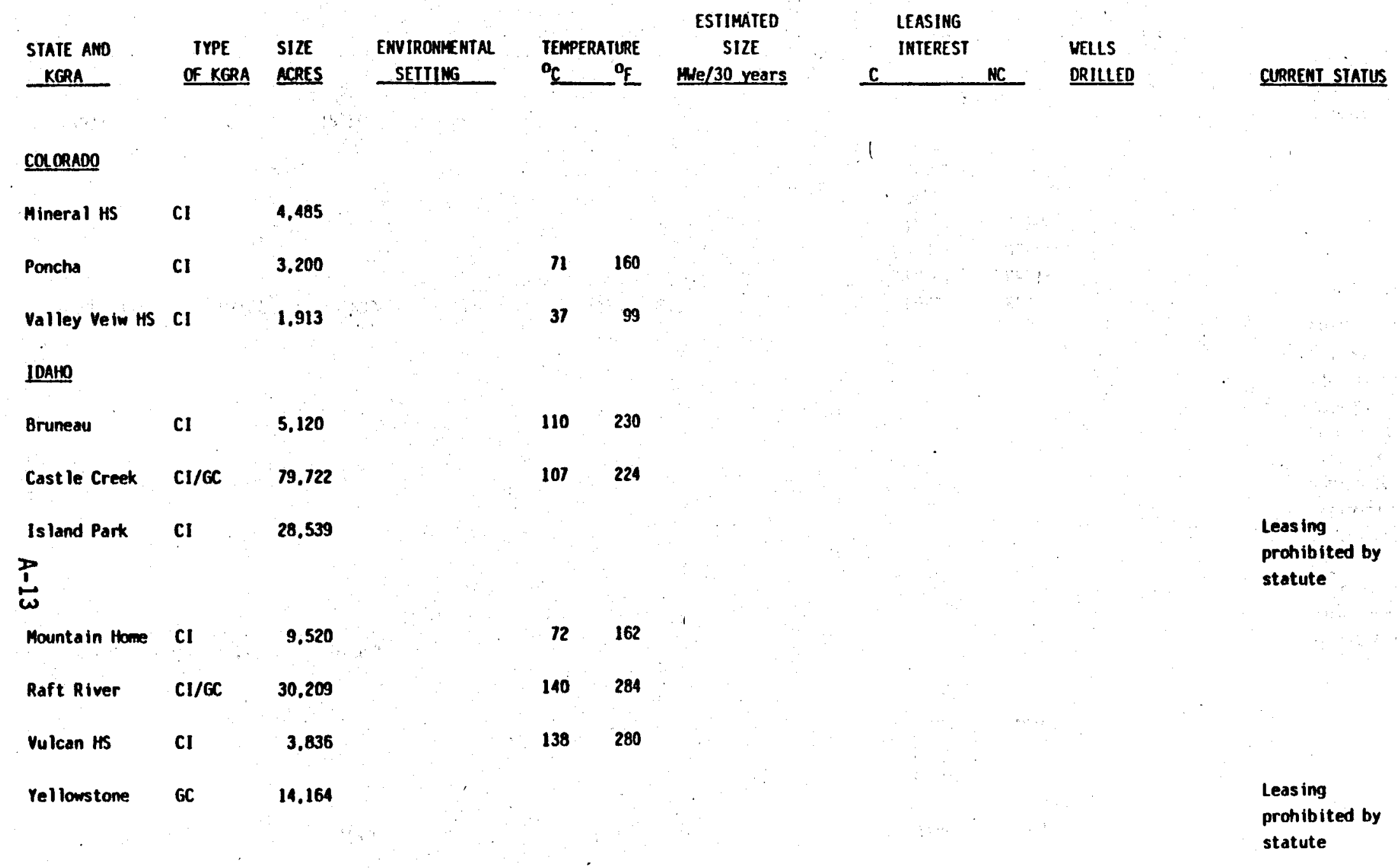




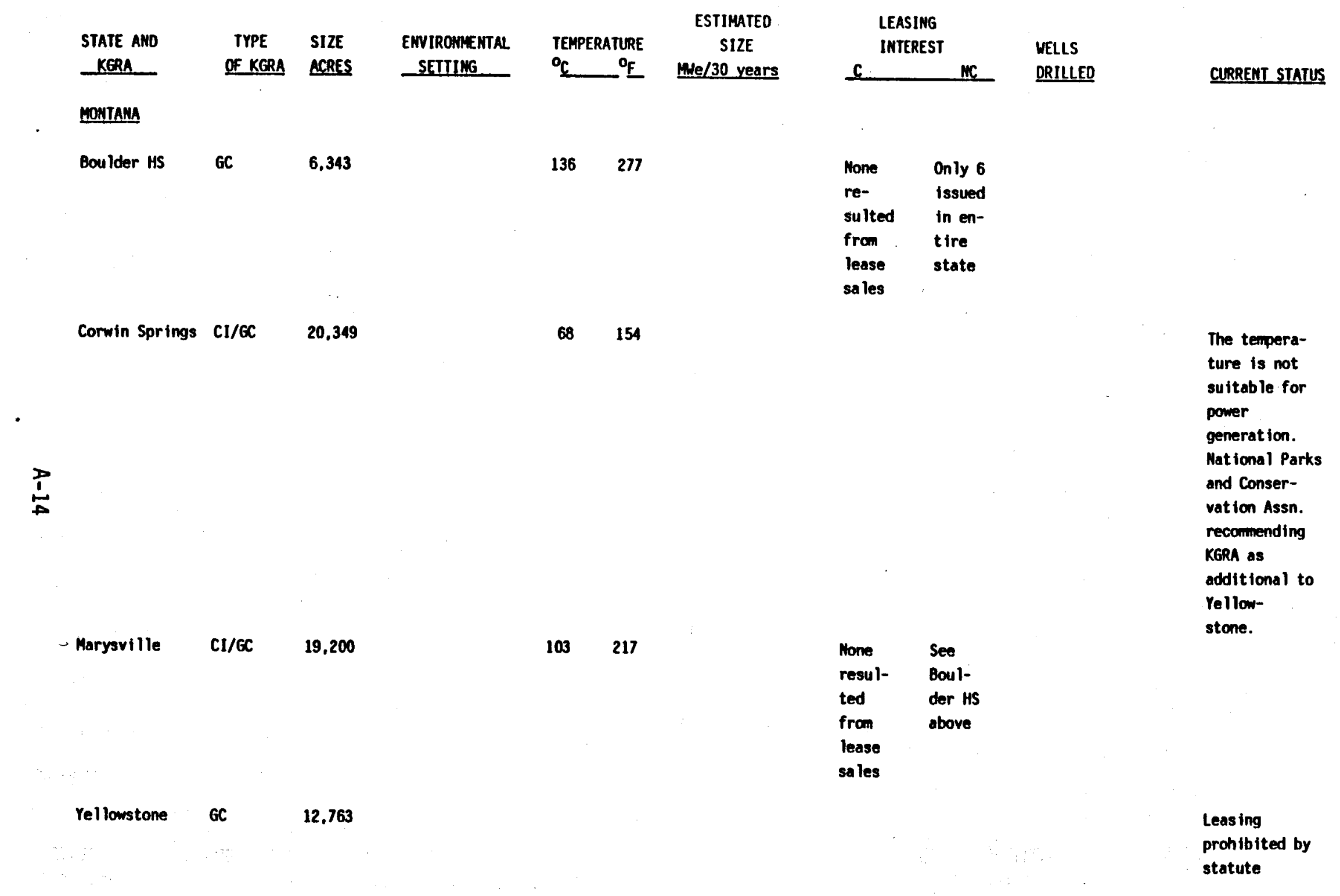




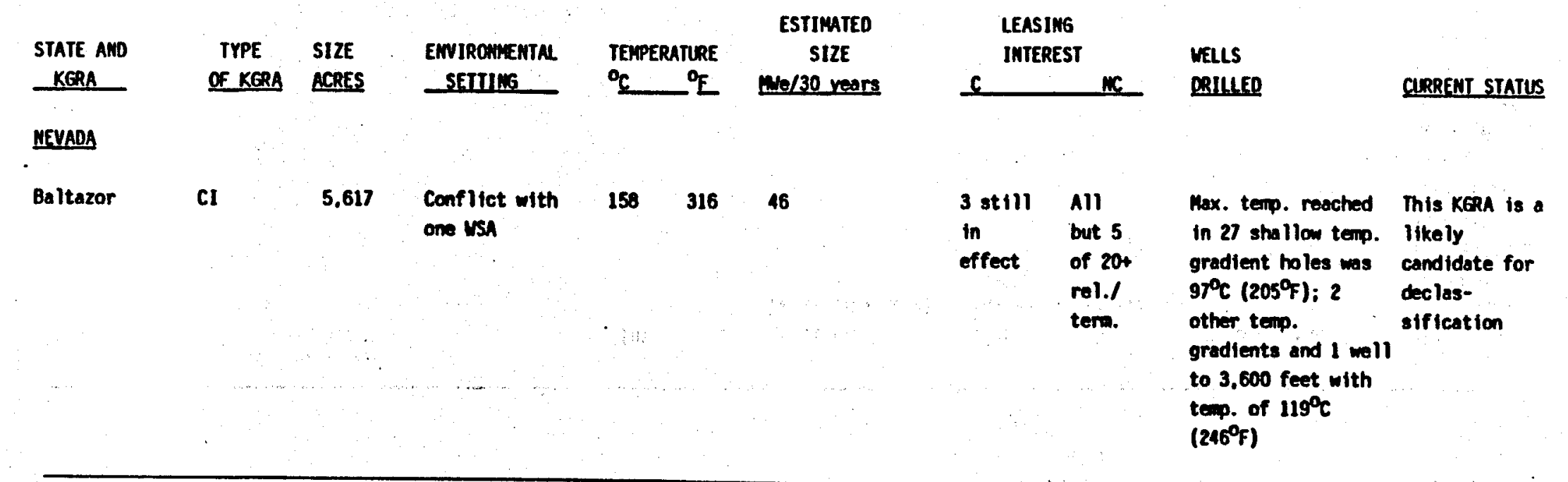

\begin{tabular}{|c|c|c|c|c|c|}
\hline$\underset{⿱ ㇒}{\stackrel{D}{\prime}}$ & $\mathrm{CI} / \mathrm{GC}$ & 26,180 & $\begin{array}{l}\text { Character ized by } \\
\text { a large sinter } \\
\text { deposit (approx. } \\
3 / 4 \mathrm{ml} \text {. lang and } \\
1 / 4 \mathrm{mi} \text {. wide). } \\
\text { hot springs. } \\
\text { pools. mud pots. } \\
\text { funaroles. and } \\
\text { an internittent. } \\
\text { geyser. }\end{array}$ & 226 & 444 \\
\hline
\end{tabular}

Current developer interest centered only on area under developnent.

10+ is- of over sued; all 20+, only except 2 sur-

those in vive; one Chevron's in the

init in- producing active unit itself
Magme Power drilled One 16.6 me 11 shallow wells (gross) plant from 1959-1965:

Chevron's extensive on Iine; if exploration program proves

substantial and future economics for geothermal

power are good, expansion is planned. Hell test ing has verified that the system is very large. with no production boundaries seen to date. and very prolific with all wells showing extremely high permeability. 


\begin{tabular}{|c|c|c|c|c|c|c|c|c|c|c|}
\hline STATE AND & TYPE & SIZE & ENVIRONEENTAL & TEMPERT & ATURE & $\begin{array}{l}\text { ESTIMATED } \\
\text { SIZE }\end{array}$ & $\begin{array}{l}\text { LEASIN } \\
\text { IMTERE }\end{array}$ & & MELLS & \\
\hline KGRA & OF KGRA & ACRES & SEITIMG & ${ }^{\circ} \mathrm{C}$ & $-{ }^{{ }^{E}} \mathbf{E}$ & Me/30 years & $c$ & $M$ & DRILLED & CURREMT STATUS \\
\hline Brady-Hazen & $\mathrm{Cl} / \mathrm{GC}$ & 98,508 & $\begin{array}{l}\text { Power plant site } \\
\text { at Desert Poak } \\
\text { is in a desolate } \\
\text { range of hills } \\
\text { with no scentc } \\
\text { or unique } \\
\text { features; } \\
\text { current land } \\
\text { uses ituited to } \\
\text { geothernal } \\
\text { exploration. } \\
\text { cattle grazing. } \\
\text { and food } \\
\text { processing } \\
\text { ut ilizing } \\
\text { geothermal } \\
\text { fluids. }\end{array}$ & $\begin{array}{l}225 \\
\text { (Des- } \\
\text { ert } \\
\text { Peak) } \\
155 \\
\text { (Brady } \\
\text { HS) }\end{array}$ & $\begin{array}{l}436 \\
\text { (Des- } \\
\text { ert } \\
\text { Peak) } \\
310 \\
\text { (Brady } \\
\text { HS) }\end{array}$ & 157 (Desert Peak) & $\begin{array}{l}\text { Mixed } \\
\text { record: } \\
\text { through } \\
5 \text { lease } \\
\text { sa les } \\
\text { many } \\
\text { tracts } \\
\text { offored } \\
2 \text { and } 3 \\
\text { times } \\
\text { received } \\
\text { no bids; } \\
\text { yet about } \\
15 \text { leases } \\
\text { mere tssie } \\
\text { All but } \\
\text { those at } \\
\text { Desert Pea } \\
\text { are now re } \\
\text { term. }\end{array}$ & Min inal & $\begin{array}{l}\text { Full field } \\
\text { deve lopment }\end{array}$ & $\begin{array}{l}9 \text { me plant on } \\
\text { line at Desert } \\
\text { Peak; no } \\
\text { further } \\
\text { deve lopment } \\
\text { announced. } \\
\text { According to } \\
\text { Enviromental } \\
\text { Assessment. } \\
\text { the Brady Hot } \\
\text { Springs } \\
\text { reservoir is } \\
\text { centered on a } \\
\text { single fault } \\
\text { and appears to } \\
\text { be too small } \\
\text { for power } \\
\text { generation. }\end{array}$ \\
\hline Colado & CI & 640 & & 101 & 213 & $\begin{array}{l}\left(0.044 \times 10^{18} \mathrm{~J}\right. \\
\text { beneficial heat) }\end{array}$ & $\begin{array}{l}1 \text { re- } \\
\text { ma ins } \\
\text { act ive }\end{array}$ & $\begin{array}{l}-5 \\
\text { act ive }\end{array}$ & Wone recorded & $\begin{array}{l}\text { This very } \\
\text { small KGRA lo- } \\
\text { cated at the } \\
\text { tom of Colado } \\
\text { in north- } \\
\text { western Nevada } \\
\text { is not likely } \\
\text { to see power } \\
\text { deve lopment } \\
\text { with its } \\
\text { temperature. }\end{array}$ \\
\hline
\end{tabular}




\begin{tabular}{|c|c|c|c|c|c|c|c|c|c|}
\hline $\begin{array}{l}\text { STATE AND } \\
\text { KERA } \\
\end{array}$ & $\begin{array}{c}\text { TrPE } \\
\text { Of KGRA }\end{array}$ & $\begin{array}{l}\text { SIIEE } \\
\text { ACRES }\end{array}$ & $\begin{array}{l}\text { ENVIRONEEMTAL } \\
\text { SEIIIMG } \\
\end{array}$ & $\begin{array}{l}\text { TEMPERATURE } \\
{ }^{\circ} \mathrm{C}\end{array}$ & $\begin{array}{c}\text { ESTIMATED } \\
\text { SIZE } \\
\text { me/30 vears }\end{array}$ & $\begin{array}{r}\text { LEASII } \\
\text { INTERE } \\
\mathrm{C} \\
\end{array}$ & ST & $\begin{array}{l}\text { VELLS } \\
\text { PRILLED }\end{array}$ & CURREAT STATUS \\
\hline Darrough H.S. & . & $\begin{array}{l}8.363 \\
\vdots \\
\vdots\end{array}$ & $\begin{array}{l}\text { In some areas. } \\
\text { hillstdes are } \\
\text { scarred with } \\
\text { mining activity. } \\
\text { and mumerous } \\
\text { thermal springs } \\
\text { are scattered } \\
\text { throughout the } \\
\text { area. Although } \\
\text { protect ion of } \\
\text { wild horses and } \\
\text { burros is. } \\
\text { required. there }\end{array}$ & $\begin{array}{l}132 \quad 270 \\
\text { are no } \\
\text { threatened or } \\
\text { endangered } \\
\text { species. Fores } \\
\text { Service Researc } \\
\text { Matural Areas } \\
\text { and candidates } \\
\text { for wilderness } \\
\text { and primitive } \\
\text { designation wil } \\
\text { have to be } \\
\text { avoided. }\end{array}$ & $\begin{array}{l}\left(28 \times 10^{18} \mathrm{~J}\right. \\
\text { beneficial heat }) \\
\text { ch } \\
11\end{array}$ & $\begin{array}{c}\text { Little } \\
\qquad\end{array}$ & $\begin{array}{l}\text { Very } \\
\text { act ive- } \\
-40 \\
\text { leases } \\
\text { stil1 } \\
\text { oct ive }\end{array}$ & $\begin{array}{l}\text { A 248-ft. well } \\
\text { reached } 129^{\circ} \mathrm{C} \\
\text { permitt ing is } \\
\text { underway for } \\
\text { development } \\
\text { drilling. }\end{array}$ & $\begin{array}{l}\text { Planning and } \\
\text { permitting } \\
\text { underway to } \\
\text { produce power. } \\
\text { Capacity not } \\
\text { yet anmounced. }\end{array}$ \\
\hline Dixle Valley & $\mathrm{Cl} / \mathrm{GC}$ & 129.361 & $\begin{array}{l}\text { Very low } \\
\text { sensitivity. } \\
\text { BLM VRH Class } \\
\text { IV. }\end{array}$ & 145 & $>150^{*}$ & $\begin{array}{l}-20 \\
\text { issued; } \\
13 \\
\text { existing }\end{array}$ & $\begin{array}{l}120^{+} \\
\text {issued; } \\
44 \\
\text { existing }\end{array}$ & $\begin{array}{l}\text { A number of } \\
\text { explorat ion wells } \\
\text { drilled by several } \\
\text { developers. } 11 \\
\text { product ion wells } \\
\text { are being used for } \\
\text { power plant. }\end{array}$ & $\begin{array}{l}\text { BLA strongly } \\
\text { supports } \\
\text { development in } \\
\text { this area. } \\
\text { oxbow, which } \\
\text { acquired the } \\
\text { leases from } \\
\text { Sun and Trans- } \\
\text { Pacific. is } \\
\text { building a } 50 \\
\text { me plant and } \\
220 \text { mi. trans- } \\
\text { mission line. }\end{array}$ \\
\hline
\end{tabular}

* Est imate from BLM Envirommental Assessment on power plant construction. 


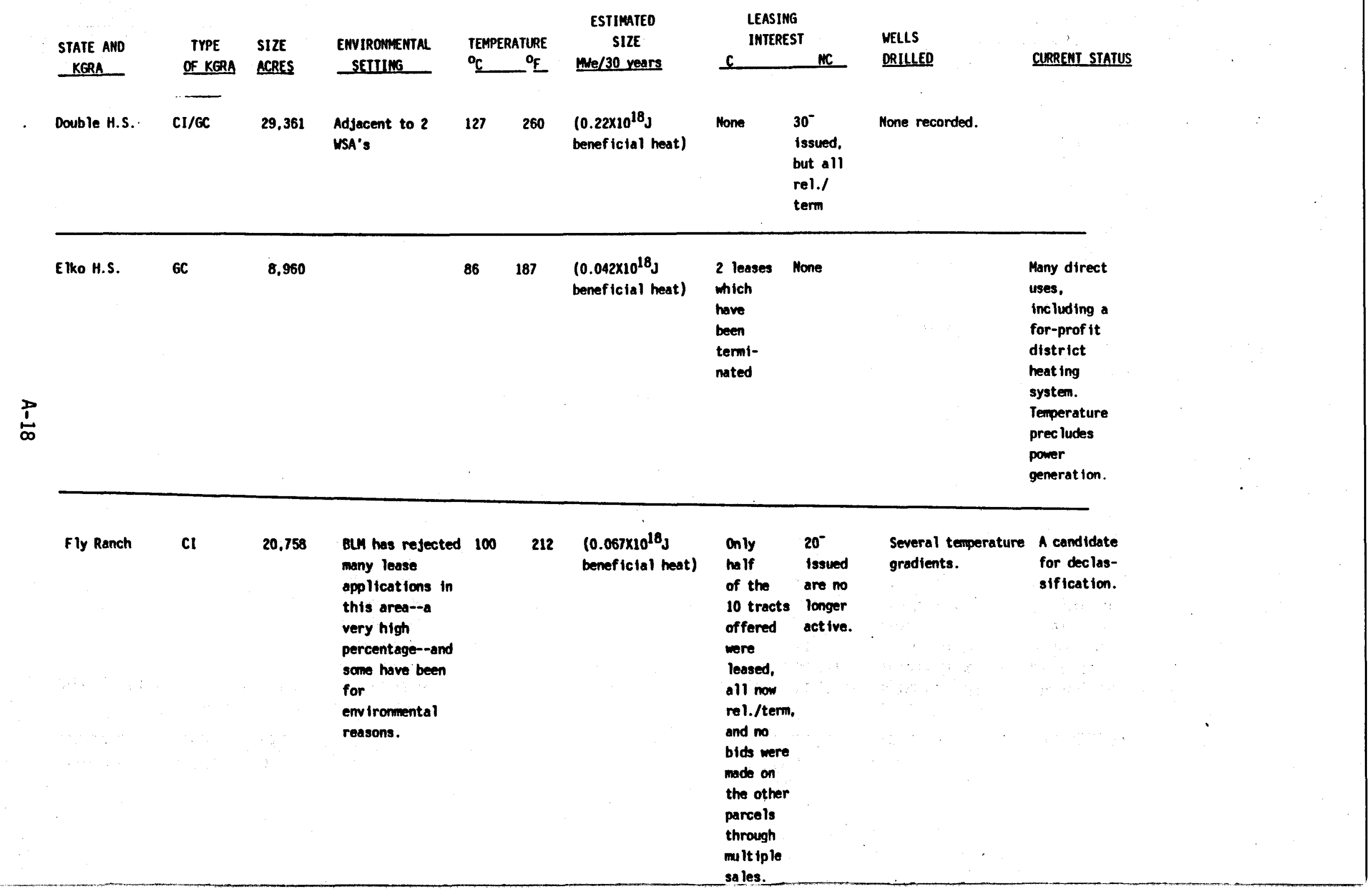




\begin{tabular}{|c|c|c|c|c|c|c|c|c|c|c|}
\hline STATE AND & TYPE & SIZE & EWIROMERTAL & & ATURE & $\begin{array}{l}\text { ESTIMATEO } \\
\text { SIZE }\end{array}$ & $\begin{array}{l}\text { LEASIM } \\
\text { IMTERE }\end{array}$ & & WELLS & DOELT CTATHE \\
\hline Ger lach & CI/EC & $\begin{array}{r}26,326 \\
-\end{array}$ & $\begin{array}{l}\text { Slight over lap } \\
\text { with USA }\end{array}$ & 170 & 338 & 32 & $\begin{array}{l}\text { Very } \\
\text { simi- } \\
\text { lar re- } \\
\text { cord to } \\
\text { to Fly } \\
\text { Ranch }\end{array}$ & $\begin{array}{l}\text { Group } \\
\text { of leases } \\
\text { unitized. } \\
\text { but unit } \\
\text { dissolved } \\
\text { and the } \\
\text { leases } \\
\text { termi- } \\
\text { nated. }\end{array}$ & $\begin{array}{l}1 \text { exploratory and } 2 \\
\text { temperature } \\
\text { gradients }\end{array}$ & $\begin{array}{l}\text { A } 2.4 \text { me } \\
\text { binary unit } \\
\text { has recent ly } \\
\text { been } \\
\text { announced. } \\
\vdots \\
\vdots\end{array}$ \\
\hline $\begin{array}{l}\text { Hot Springs } \\
\text { Point }\end{array}$ & CI & 8,549 & & 87 & 189 & $\begin{array}{l}\left(0.042 \times 10^{18} \mathrm{~J}\right. \\
\text { beneficial heat })\end{array}$ & $\begin{array}{l}\text { Very } \\
\text { lit- } \\
\text { tle }\end{array}$ & $\begin{array}{l}\text { Very } \\
\text { lit- } \\
\text { tle }\end{array}$ & $\begin{array}{l}2 \text { temperature } \\
\text { gradients }\end{array}$ & \\
\hline Kyle H.S. & $G C$ & 2.560 & & 161 & 322 & 97 & $\begin{array}{l}\text { Very } \\
\text { lit- } \\
\text { tle }\end{array}$ & $\begin{array}{l}\text { Very } \\
\text { lit- } \\
\text { tle }\end{array}$ & $\therefore$ & \\
\hline Leach H.S. & $\begin{array}{c}\mathbf{C I} / \mathbf{G C} \\
\vdots \\
\end{array}$ & $\begin{array}{c}12.846 \\
\end{array}$ & $\therefore$ & 160 & 320 & $n$ & $\begin{array}{l}5 \\
\text { issued, } \\
\text { unit ized, } \\
\text { but unit } \\
\text { was dis- } \\
\text { solved } \\
\text { and the } \\
\text { leases } \\
\text { termin- } \\
\text { ated. }\end{array}$ & $\begin{array}{l}\text { Very } \\
\text { act ive } \\
\text { for a } \\
\text { t ime, } \\
\text { but no } \\
\text { leases } \\
\text { rema in } \\
\text { act ive. }\end{array}$ & 1 exp loratory & \\
\hline Moana Springs & GC & & . & 96 & 205 & $\begin{array}{l}\left(0.143 \times 10^{18} \mathrm{~J}\right. \\
\text { beneficial heat })\end{array}$ & $\begin{array}{l}\text { No com- } \\
\text { pet it ive } \\
\text { sales }\end{array}$ & $\begin{array}{l}\text { Very } \\
\text { little }\end{array}$ & & . \\
\hline
\end{tabular}




\begin{tabular}{|c|c|c|c|c|c|c|c|c|c|c|}
\hline $\begin{array}{l}\text { STATE ANO } \\
\text { KGRA }\end{array}$ & $\begin{array}{c}\text { TYPE } \\
\text { OF KGRA }\end{array}$ & $\begin{array}{l}\text { SIZE } \\
\text { ACRES }\end{array}$ & $\begin{array}{l}\text { EWVIROWMENTAL } \\
\text { SETIIIKG }\end{array}$ & & $\begin{array}{l}\text { ATURE } \\
\text { OF }\end{array}$ & $\begin{array}{c}\text { ESTIMATED } \\
\text { S1ZE }\end{array}$ & LEAS & IG & MELLS & \\
\hline Pinto H.S. & $\mathrm{CI} / \mathrm{GC}$ & 8,015 & Enbraces 1 WSA & 176 & 349 & 90 & $\begin{array}{l}\text { Very } \\
\text { lit- } \\
\text { tle }\end{array}$ & $\begin{array}{l}\text { Very } \\
\text { lit- } \\
\text { tle }\end{array}$ & & \\
\hline Ruby Valley & CI/GC & 5.743 & & 96 & 205 & & $\begin{array}{l}\text { Very } \\
\text { lit- } \\
\text { tle }\end{array}$ & $\begin{array}{l}\text { Very } \\
\text { lit- } \\
\text { tle }\end{array}$ & None recorded. & \\
\hline Rye Patch & CI & 801 & & 218 & 423 & & $\begin{array}{l}\text { One } \\
\text { cont } \\
\text { pany } \\
\text { has a } \\
\text { lease } \\
\text { for the } \\
\text { entire } \\
\text { KGRA }\end{array}$ & $\begin{array}{l}20^{-} \\
\text {issued, } \\
\text { and very } \\
\text { low } \\
\text { inci- } \\
\text { dence } \\
\text { of rel./ } \\
\text { term. } \\
\end{array}$ & $\begin{array}{l}\text { Two deve lopers have } \\
\text { drilled } 2 \\
\text { exploratory and } 1 \\
\text { temperature } \\
\text { gradient. }\end{array}$ & $\begin{array}{l}\text { Whlle no power } \\
\text { development } \\
\text { plans have } \\
\text { been amnounc- } \\
\text { ed, this KGRA } \\
\text { mas placed on } \\
\text { the priority } \\
\text { list because } \\
\text { of its } \\
\text { tenperature. } \\
\text { and high } \\
\text { deve loper } \\
\text { interest. }\end{array}$ \\
\hline
\end{tabular}

\begin{tabular}{|c|c|c|c|c|c|c|c|}
\hline $\begin{array}{l}\text { San Emidio } \\
\text { Desert }\end{array}$ & Cl/GC & 7.678 & 166 & 331 & $\begin{array}{l}\text { Little } \\
\text { no ac- } \\
\text { tive } \\
\text { leases }\end{array}$ & $\begin{array}{l}\text { Little- } \\
\text { no ac- } \\
\text { tive } \\
\text { leases }\end{array}$ & $\begin{array}{l}2 \text { exploratory wells } \\
\text { found disappo int ing } \\
\text { tenperatures for } \\
\text { power generat ion }\end{array}$ \\
\hline
\end{tabular}




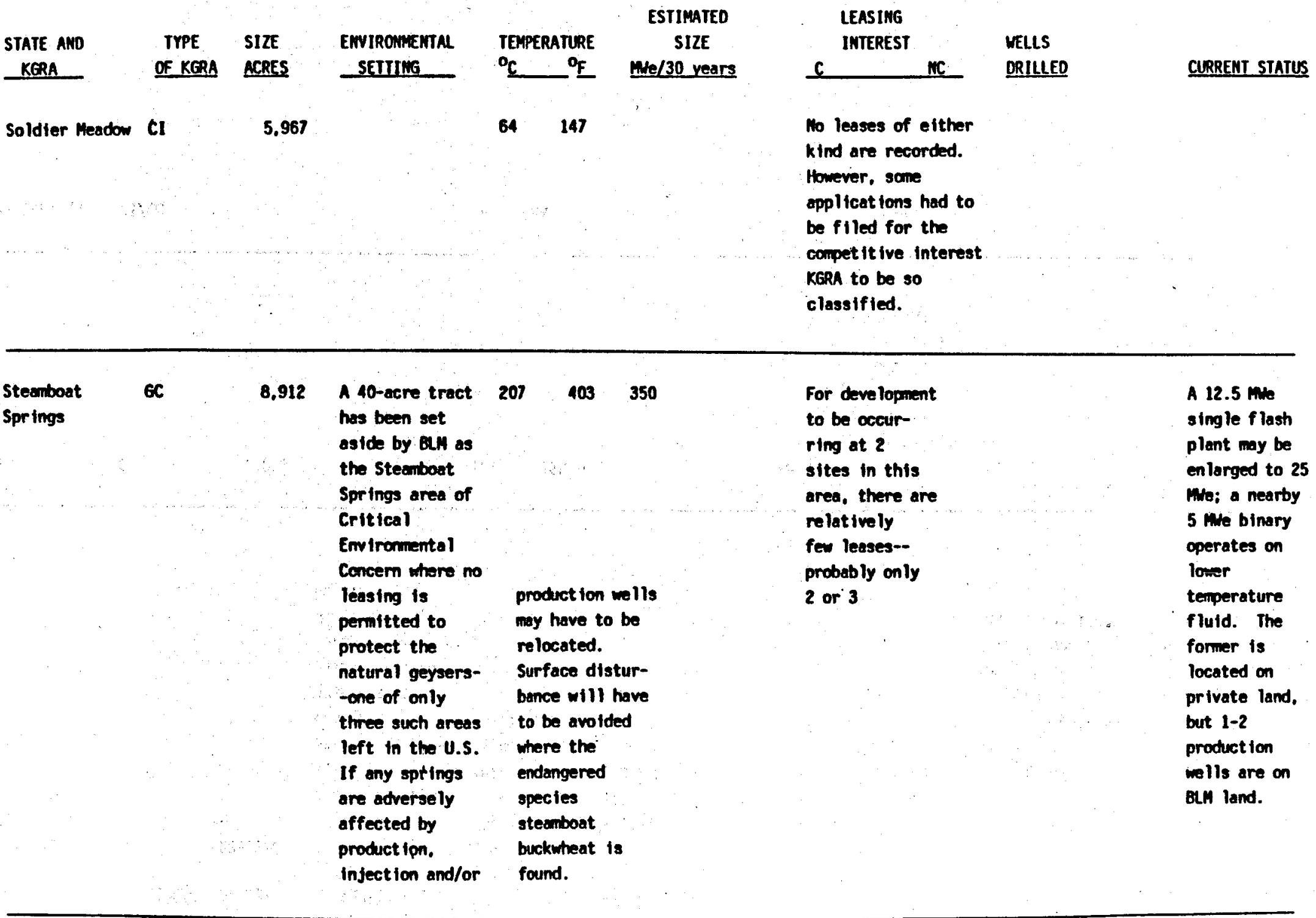




\begin{tabular}{|c|c|c|c|c|c|c|c|c|c|c|}
\hline \multirow{2}{*}{$\begin{array}{l}\text { STATE AND } \\
\text { KGRA } \\
\end{array}$} & \multirow{2}{*}{$\begin{array}{c}\text { TYPE } \\
\text { OF KGRA }\end{array}$} & \multirow{2}{*}{$\begin{array}{l}\text { SIIEE } \\
\text { ACRES }\end{array}$} & \multirow{2}{*}{$\begin{array}{l}\text { EWVIRONFENTAL } \\
\text { SETIIMG } \\
\end{array}$} & \multicolumn{2}{|c|}{ TEMPERATURE } & \multirow{2}{*}{$\begin{array}{c}\text { ESTIMATED } \\
\text { SIZE } \\
\text { Me/30 years }\end{array}$} & \multicolumn{2}{|c|}{$\begin{array}{l}\text { LEAS ING } \\
\text { INTEREST }\end{array}$} & \multicolumn{2}{|l|}{ MELLS } \\
\hline & & & & ${ }^{\circ} \mathrm{C}$ & $\mathbf{O}^{\mathbf{O}} \mathbf{E}$ & & $c$ & MC & DRILLED & CURRENT STATUS \\
\hline $\begin{array}{l}\text { Stilliwater- } \\
\text { Soda Lake }\end{array}$ & GC & 225.260 & $\begin{array}{l}\text { Sensitivity is } \\
\text { very low; } \\
\text { assigned a BLA } \\
\text { VRH IV; there } \\
\text { are no residen- } \\
\text { ces on or } \\
\text { adjacent to } \\
\text { plant site; no } \\
\text { rare or en- } \\
\text { dangered } \\
\text { species. }\end{array}$ & $\begin{array}{l}159 \\
\text { (St ill } \\
\text { water) } \\
161 \\
\text { (Soda } \\
\text { Lake) }\end{array}$ & $\begin{array}{l}318 \\
\text { I-St (III) } \\
\text { water) } \\
146 \\
\text { (Soda } \\
\text { Lake) }\end{array}$ & $\begin{array}{l}450 \\
\text { (St I111water) } \\
146 \\
\text { (Soda Lake) }\end{array}$ & $\begin{array}{l}5 \text { re- } \\
\text { ma in } \\
\text { ac- } \\
\text { tive }\end{array}$ & $\begin{array}{l}\text { Mini- } \\
\text { mal -- } \\
3 \text { remain } \\
\text { act ive }\end{array}$ & $\begin{array}{l}10 \text { exploratory } \\
\text { wells and } 2 \\
\text { shallow tempera- } \\
\text { ture gradient } \\
\text { wells drilled } \\
\text { prior to } 1982 \text { by } \\
\text { several develop- } \\
\text { ers. Highest } \\
\text { temperature re- } \\
\text { corded was } 178^{\circ} \mathrm{C} \text {. }\end{array}$ & $\begin{array}{l}\text { Chevron plans } \\
\text { to construct a } \\
2.4 \text { Mie plant } \\
\text { to use wells } \\
\text { previously } \\
\text { drilled by } \\
\text { Phillips, from } \\
\text { thon Chevron } \\
\text { purchased the } \\
\text { property. }\end{array}$ \\
\hline
\end{tabular}

\begin{tabular}{|c|c|c|c|c|c|c|}
\hline Irego & . & 7,013 & 124 & 255 & None & $\begin{array}{l}\text { Minimal } \\
\text {-- only } 2 \\
\text { renain } \\
\text { act ive } \\
\text { out of } \\
\text { about } 15 \\
\text { issued }\end{array}$ \\
\hline
\end{tabular}

Warm Springs CI/GC

MA MA

Hone Hone 


\begin{tabular}{|c|c|c|c|c|c|c|c|c|c|c|}
\hline \multirow{2}{*}{$\begin{array}{l}\text { STATE ANO } \\
\text { KERA } \\
\text { MEU MEXICO }\end{array}$} & \multirow[t]{2}{*}{$\begin{array}{c}\text { TYPE } \\
\text { Of } \mathrm{KGRA}\end{array}$} & $\begin{array}{l}\text { SIZE } \\
\text { ACRES }\end{array}$ & $\begin{array}{l}\text { ENIRONEETRR } \\
\text { SETIILG }\end{array}$ & \multicolumn{2}{|c|}{$\begin{array}{l}\text { TEUPERATURE } \\
{ }^{\circ} \text { C }\end{array}$} & $\begin{array}{l}\text { ESTIMATED } \\
\text { SIZE } \\
\text { me/30 vears }\end{array}$ & \multicolumn{2}{|c|}{$\begin{array}{l}\text { LEASING } \\
\text { INTEREST }\end{array}$} & $\begin{array}{l}\text { MELLS } \\
\text { DRILLED }\end{array}$ & CURRENT STATUS \\
\hline & & & & & & & & & & \\
\hline $\begin{array}{l}\text { Baca Location } \\
\text { No. } 1\end{array}$ & $6 C$ & 164,696 & $\begin{array}{l}\text { Area en- } \\
\text { conposes } \\
\text { historical. } \\
\text { archeologite. } \\
\text { scenic, and } \\
\text { Indian religtous } \\
\text { sites; habitats } \\
\text { for endangered } \\
\text { species, } \\
\text { considerable } \\
\text { acreage } \\
\text { potent lal } \\
\text { wilderness }\end{array}$ & 278 & 531 & $\begin{array}{l}2,700 \text { est imated } \\
\text { by Circular } 790 ; \\
\text { insuffictent fluid } \\
\text { found to support } \\
50 \text { me plant }\end{array}$ & $\begin{array}{l}8 \text { re- } \\
\text { main } \\
\text { act ive } \\
\text { although } \\
\text { equal } 1 \text { - } \\
\text { no. rel./ } \\
\text { term }\end{array}$ & $\begin{array}{c}\text { Hone } \\
\vdots \\
\vdots \\
\vdots\end{array}$ & $\begin{array}{l}\text { Mearly } 20 \text { wells } \\
\text { ranging from } 671 \text { - } \\
5,502 \text { feet }\end{array}$ & $\begin{array}{l}\text { Unocal retains } \\
\text { its properties } \\
\text { in the area; } \\
\text { no amounced } \\
\text { plans for } \\
\text { snaller } \\
\text { capacity } \\
\text { development. }\end{array}$ \\
\hline Gila H.S. & CI & 3,202 & $\begin{array}{l}\text { Geothermal } \\
\text { development } \\
\text { compat ible with } \\
\text { purposes for } \\
\text { which } 6 \text { ila } \\
\text { Nat tonal for- } \\
\text { est was cre- } \\
\text { ated, provided } \\
\text { that the iden- } \\
\text { tif ied areas of } \\
\text { greatest } \\
\text { enviromental } \\
\text { sensit ivity are } \\
\text { protected; abuts } \\
\text { Gila Wilderness } \\
\text { area. }\end{array}$ & $n$ & 171 & & $\begin{array}{l}\text { to record } \\
\text { of leasin } \\
\text { area. }\end{array}$ & $\begin{array}{l}\text { in this } \\
\text { in found }\end{array}$ & Mone recorded & $\begin{array}{l}\text { One small } \\
\text { binary unit } \\
\text { operated } \\
\text { brief ly on } 63 \\
-68^{\circ} \mathrm{C} \text { (145- } \\
155^{\circ} \mathrm{F} \text { ) feed- } \\
\text { water. Oper- } \\
\text { at ion was not } \\
\text { successful. }\end{array}$ \\
\hline
\end{tabular}




\begin{tabular}{|c|c|c|c|c|c|c|c|c|c|c|}
\hline \multirow{2}{*}{$\begin{array}{l}\text { STATE AND } \\
\text { KGRA } \\
\end{array}$} & \multirow{2}{*}{$\begin{array}{c}\text { TYPE } \\
\text { OF KCRA }\end{array}$} & \multirow{2}{*}{$\begin{array}{l}\text { SIZE } \\
\text { ACRES }\end{array}$} & \multirow{2}{*}{$\begin{array}{l}\text { ENVIROHMENTAL } \\
\text { SETIIING } \\
\end{array}$} & \multicolumn{2}{|c|}{ TEMPERATURE } & $\begin{array}{c}\text { ESTIMATED } \\
\text { SIZE }\end{array}$ & \multicolumn{2}{|c|}{$\begin{array}{l}\text { LEASING } \\
\text { INTEREST }\end{array}$} & \multicolumn{2}{|l|}{ WELLS } \\
\hline & & & & ${ }^{0} \mathrm{c}$ & $-\underline{D_{F}}$ & me/30 years & $c$ & MC & DRILLED & CLRRENT STATUS \\
\hline $\begin{array}{l}\text { Lightning } \\
\text { Dock }\end{array}$ & cl & 21,667 & & 158 & 316 & $\begin{array}{l}\left(0.070 \times 10^{18} \mathrm{~J}\right. \\
\text { beneficial heat) }\end{array}$ & $\begin{array}{l}10 \text { remain } \\
\text { active, } \\
\text { one pro- } \\
\text { ducing } \\
\text { although } \\
\text { several } \\
\text { have been } \\
\text { rel./term. }\end{array}$ & $\begin{array}{l}\text { Of nearly } \\
30 \text { is- } \\
\text { sued. } \\
\text { only } \\
3 \text { remain } \\
\text { act ive. }\end{array}$ & $\begin{array}{l}2 \text { completed before } \\
\text { 1982; a } 7,000 \text { foot } \\
\text { development well } \\
\text { completed and } \\
\text { abandoned in } 1982 \text {. }\end{array}$ & $\begin{array}{l}\text { One small } \\
\text { (<1mue) is } \\
\text { operated in } \\
\text { this area to } \\
\text { supply power } \\
\text { for a } \\
\text { greenhouse. }\end{array}$ \\
\hline
\end{tabular}

$\begin{array}{lllll}\text { Lower Frisco } & \text { Cl } & 5.760 & 99 \quad 210 & \text { No record of leases } \\ \text { H.S. } & & & \begin{array}{l}\text { in this area was } \\ \text { found. }\end{array}\end{array}$

Radium Springs CI $6.96: ? \quad 96 \quad 205$

$\begin{array}{lll}5 \text { remain } & \text { Most } & \text { In 1981, } 2 \text { wells } \\ \text { in-force; act ive } & \text { completed to } 8,000 \\ 2 \text { termi- } & \text { area in and 9,000 feet; } \\ \text { nated } & \text { N.H. with latter was } \\ \text { nearly } & \text { abandoned. } \\ & 30 \\ \text { active; } \\ \text { very low } \\ \text { percen- } \\ \text { tage of } \\ \text { rel.l } \\ \text { term. }\end{array}$

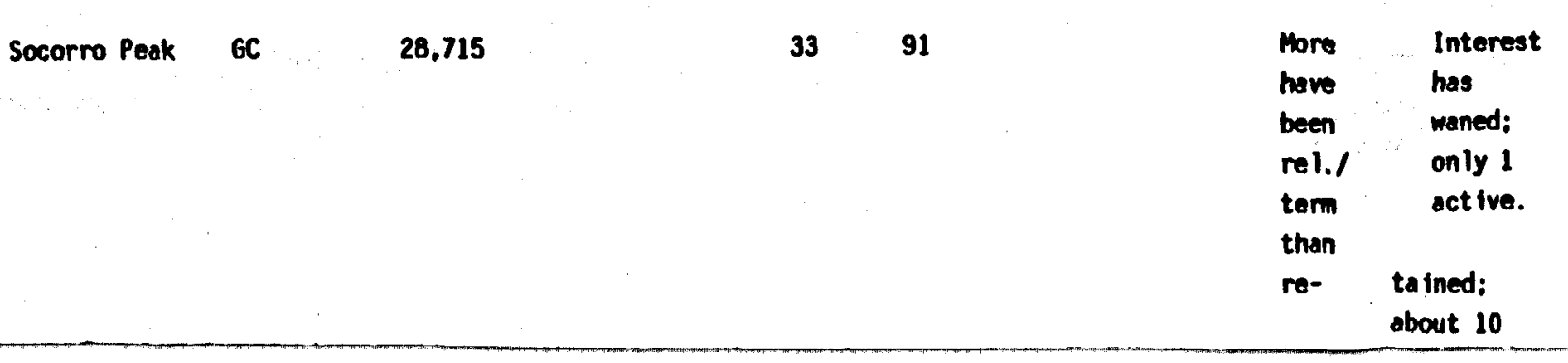




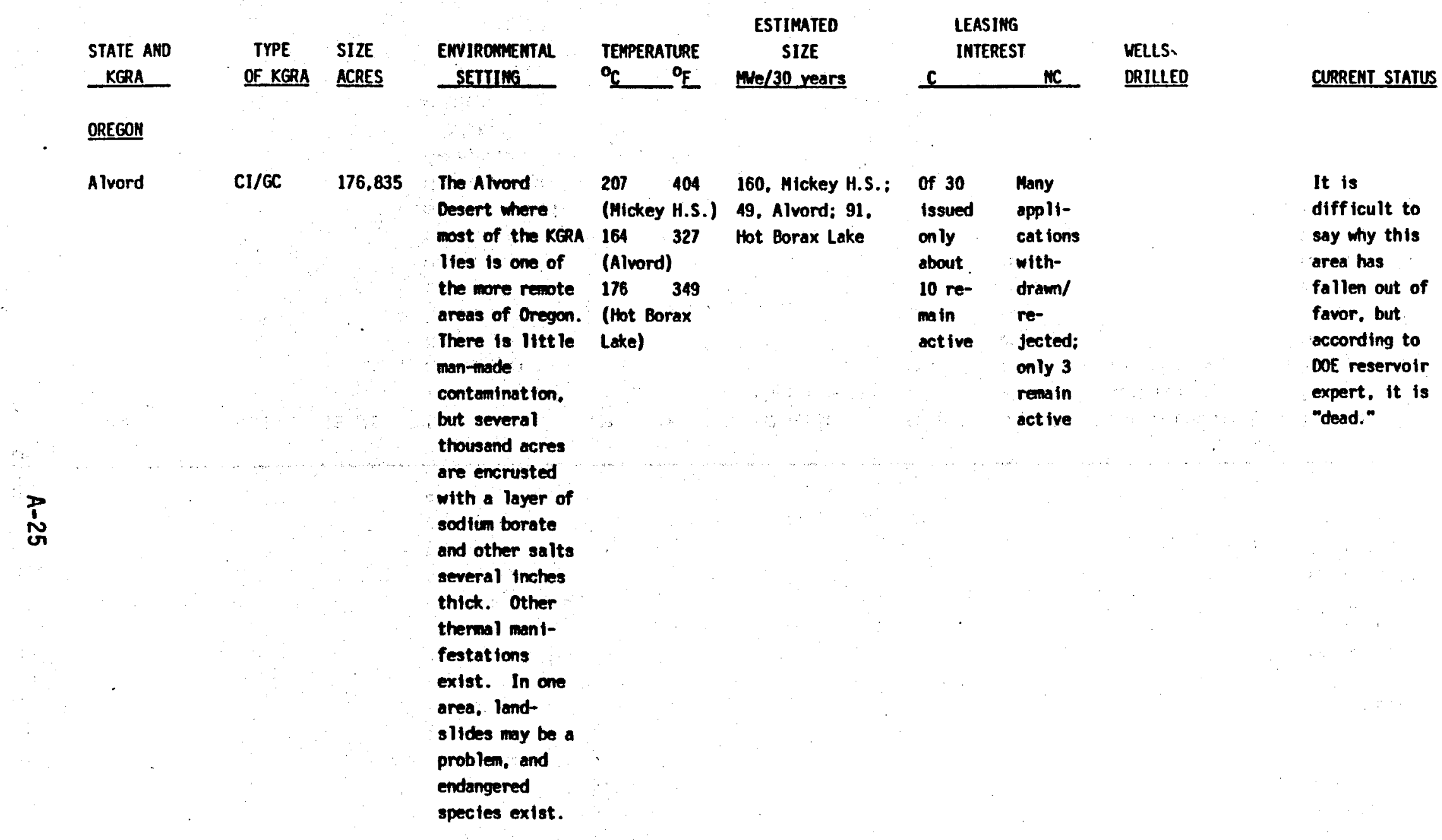




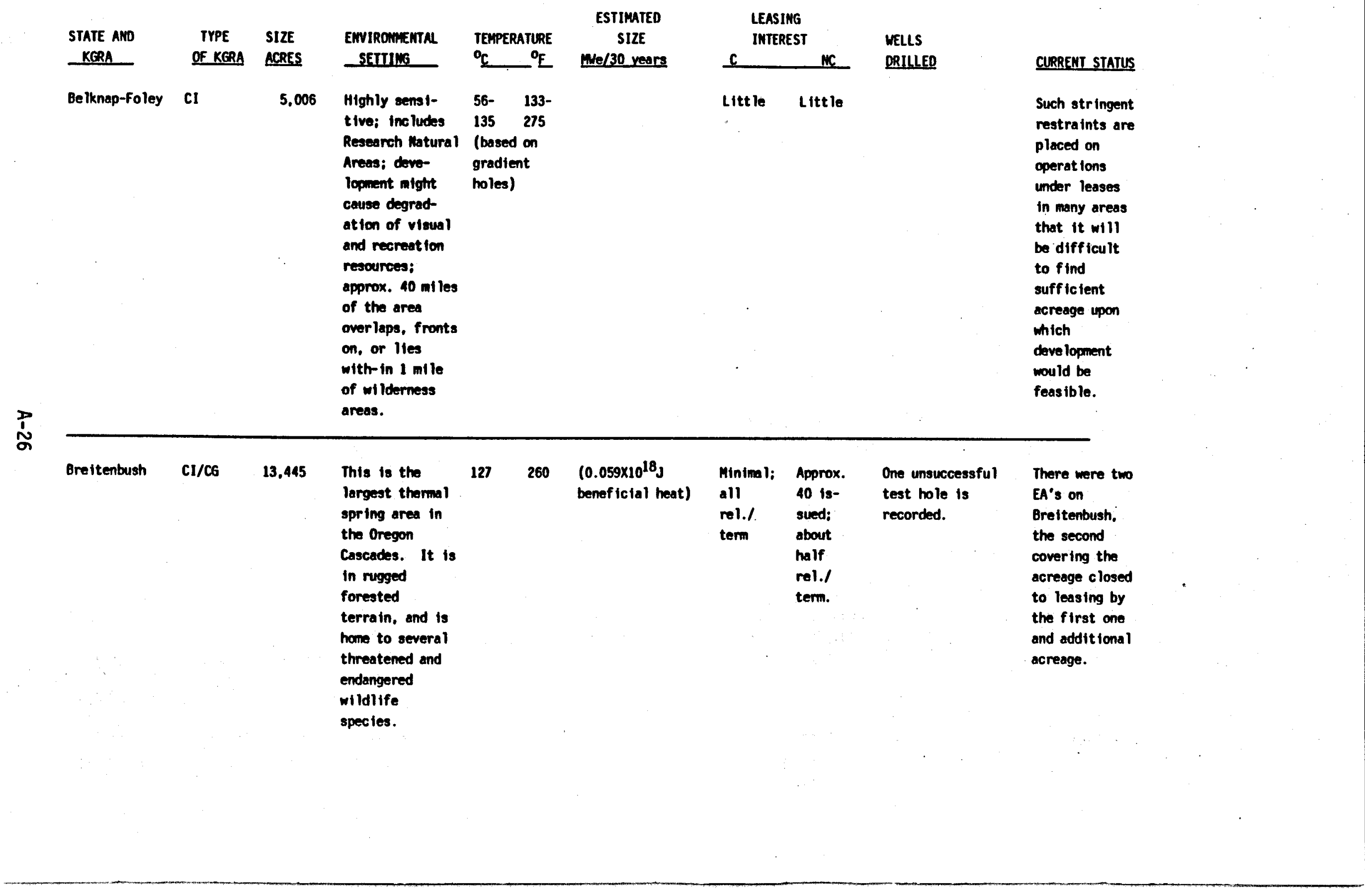




\begin{tabular}{|c|c|c|c|c|c|c|c|c|c|}
\hline $\begin{array}{l}\text { STATE AND } \\
\text { KGRA } \\
\end{array}$ & $\begin{array}{c}\text { TYPE } \\
\text { OF KGRA }\end{array}$ & $\begin{array}{l}\text { SILE } \\
\text { ACRES }\end{array}$ & $\begin{array}{l}\text { ENWIRONMENTAL } \\
\text { SETIIMG } \\
\end{array}$ & $\begin{array}{l}\text { TEMPERATURE } \\
{ }^{\circ} \mathrm{C}\end{array}$ & $\begin{array}{c}\text { ESTIMATEO } \\
\text { SIZE } \\
\text { He/30 vears }\end{array}$ & $\begin{array}{r}\text { LEA } \\
\text { INTI } \\
\mathrm{C}^{\text {IN }} \\
\end{array}$ & $\begin{array}{l}16 \\
\text { ST } \\
\quad M C\end{array}$ & $\begin{array}{l}\text { WELLS } \\
\text { DRILLED }\end{array}$ & CURRENT STATUS \\
\hline Carey H.S. & $6 C$ & 7,579 & & $98 \quad 208$ & $\begin{array}{l}\left(0.048 \times 10^{18} \mathrm{~J}\right. \\
\text { benefictal heat) }\end{array}$ & & & & \\
\hline Crump Geyser & CI/GC & 85,663 & $\begin{array}{l}\text { Abuts the Hart } \\
\text { Mountain } \\
\text { antelope refuge }\end{array}$ & 173 & 61 & $\begin{array}{l}10^{+} \text {is- } \\
\text { sued; } \\
\text { none } \\
\text { rema in } \\
\text { active. }\end{array}$ & $\begin{array}{l}40^{+} \text {is- } \\
\text { sued: } \\
\text { all } \\
\text { but } \\
1 \text { rel. } 1 \\
\text { term. }\end{array}$ & $\begin{array}{l}\text { One at } 1,684 \text { feet } \\
\text { spouted boiling } \\
\text { water for several } \\
\text { months at } 1,500- \\
2,3001 / \text { min; max. } \\
\text { temp. } 121 \text { C }\left(250^{\circ} \mathrm{F}\right)\end{array}$ & \\
\hline Klamath Falls & $\mathrm{CI} / \mathrm{GC}$ & 29.869 & . & $\begin{array}{l}104 \quad 219 \\
\text { Circular 790; } \\
150-\quad 300- \\
190 \quad 374 \\
\text { LBL Hodel }\end{array}$ & $\begin{array}{l}\left(1.79 \times 10^{18} \mathrm{~J}\right. \\
\text { beneficial heat) }\end{array}$ & & & . & $\begin{array}{l}\text { Oue to the } \\
\text { fact that LBL } \\
\text { est imated a } \\
\text { much higher } \\
\text { tem- perature } \\
\text { than USGS } \\
\text { after recent } \\
\text { wrik in the } \\
\text { area, Klamath } \\
\text { Falls was } \\
\text { placed on the } \\
\text { list for } \\
\text { roya ity } \\
\text { projection. }\end{array}$ \\
\hline
\end{tabular}




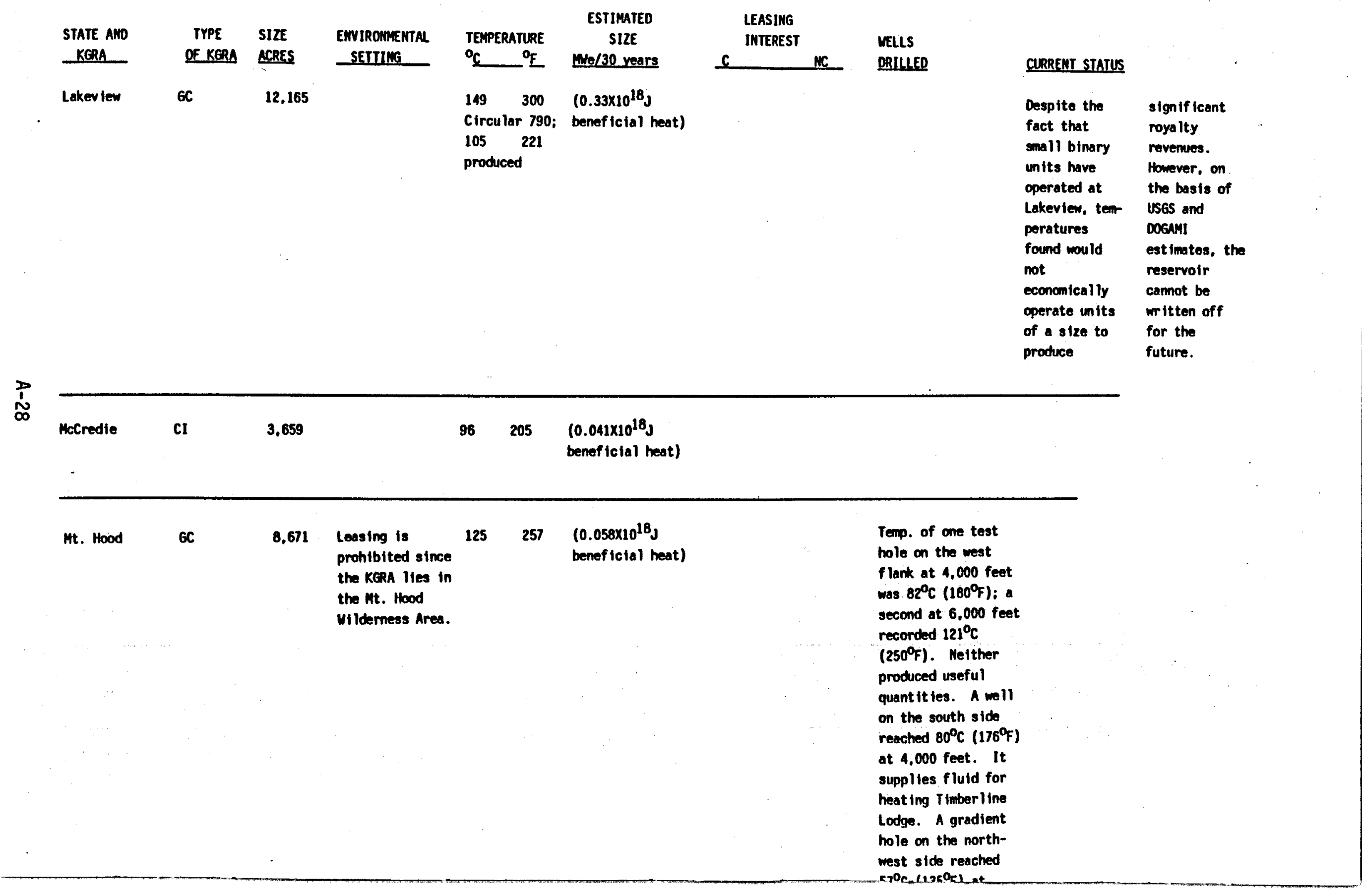




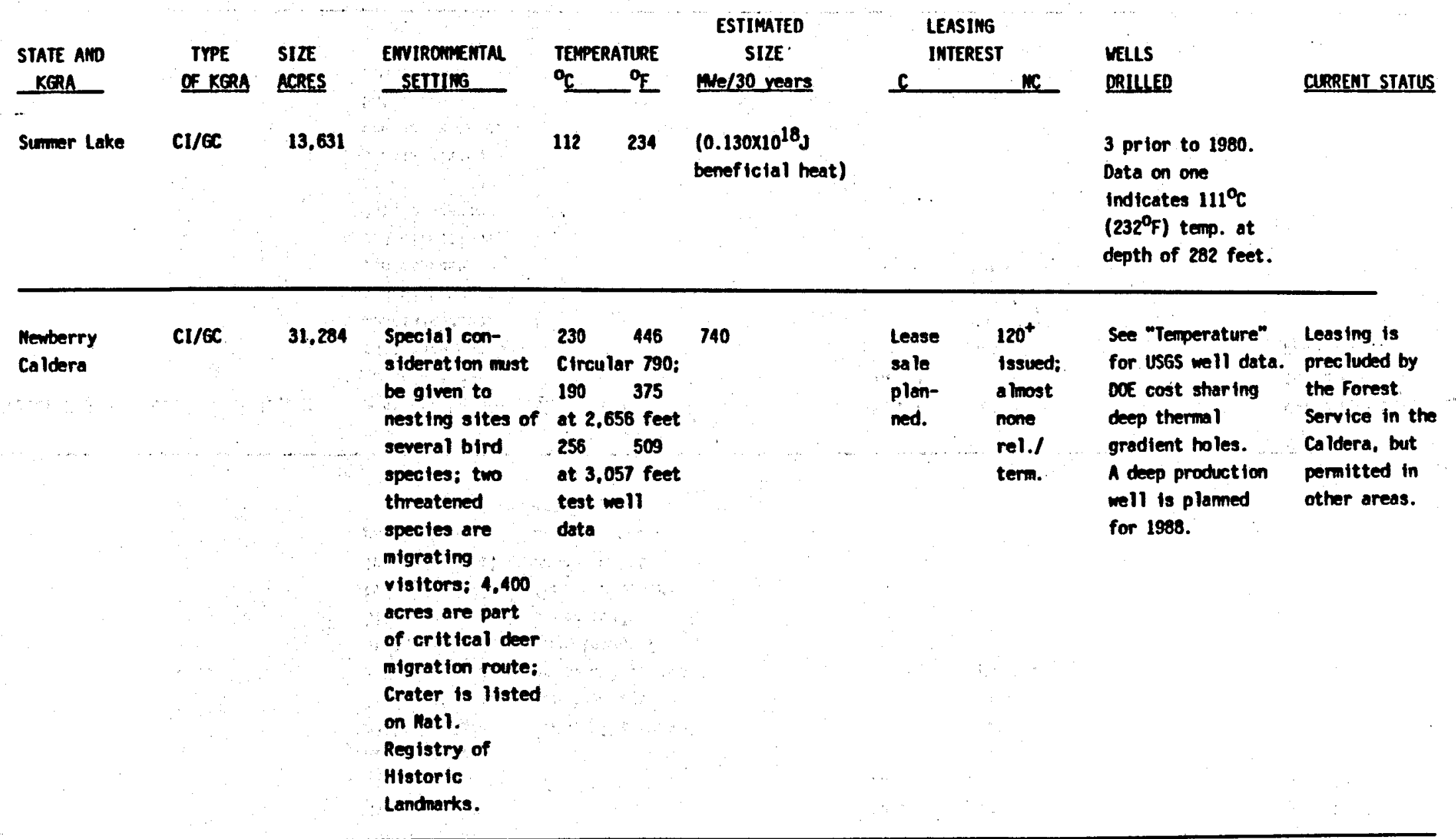

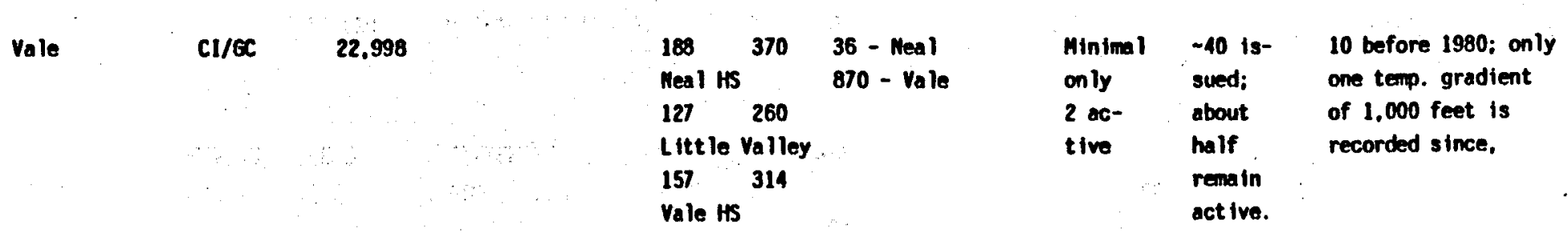




\begin{tabular}{|c|c|c|c|c|c|c|c|c|c|}
\hline STATE AMD & $\begin{array}{l}\text { TYPE } \\
\text { OF KGRA }\end{array}$ & SIZE. & $\begin{array}{l}\text { EWVIRONMENTAL } \\
\text { SETIMG }\end{array}$ & $\begin{array}{l}\text { TEMPERATURE } \\
\text { OC }\end{array}$ & $\begin{array}{l}\text { ESTIMATED } \\
\text { SIZE }\end{array}$ & $\begin{array}{l}\text { LEA } \\
\text { INT }\end{array}$ & $\begin{array}{l}\text { NG } \\
\text { EST }\end{array}$ & MELLS & CIPPEYT STATUS \\
\hline UTAH & & & & & & & & & \\
\hline $\begin{array}{l}\text { Cove Fort- } \\
\text { Sulphurda le }\end{array}$ & CI & 24,074 & $\begin{array}{l}\text { The eastern and } \\
\text { northern por- } \\
\text { t lons of the } \\
\text { area are } \\
\text { mountainous } \\
\text { a lthough cove } \\
\text { Ft., listed as } \\
\text { a Nat lonal and } \\
\text { State Historic } \\
\text { site, is loca- } \\
\text { ted in a valley } \\
\text { in the central } \\
\text { part of the }\end{array}$ & $\begin{array}{l}265509 \\
\text { KGAA. The area } \\
\text { has been active } \\
\text { setsmically, and } \\
\text { the mining of } \\
\text { water could } \\
\text { increase occur- } \\
\text { rence and se- } \\
\text { erity of the } \\
\text { activity. }\end{array}$ & d & $\begin{array}{l}10 \text { ac- } \\
\text { tive: } \\
\text { some } \\
\text { rel./ } \\
\text { term. }\end{array}$ & $\begin{array}{l}\text { Less } \\
\text { than } \\
10 \text { re- } \\
\text { ma in } \\
\text { act ive } \\
\text { out of } \\
70^{+} \\
\text {issued. }\end{array}$ & $\begin{array}{l}\text { Full field } \\
\text { development. }\end{array}$ & $\begin{array}{l}6.5 \text { me binary } \\
\text { copacity is } \\
\text { operat ing on } \\
\text { dry steam. }\end{array}$ \\
\hline Crater H.S. & $G C$ & 17.321 & $\begin{array}{l}\text { Most of the area } \\
\text { is relatively } \\
\text { f lat although } \\
\text { mountain rages } \\
\text { and high peaks } \\
\text { can be seen in } \\
\text { all directions: } \\
\text { little scenic } \\
\text { appeal and no } \\
\text { people living in } \\
\text { the lease area. } \\
\text { but nearby } \\
\text { communities. }\end{array}$ & 97 & & $\begin{array}{l}\text { Only, } 1 \\
\text { active }\end{array}$ & $\begin{array}{l}\text { Act ive } \\
\text { early. } \\
\text { but all } \\
\text { have been } \\
\text { rel./ } \\
\text { term. }\end{array}$ & & $\begin{array}{l}\text { Water appears } \\
\text { to be a } \\
\text { problem. }\end{array}$ \\
\hline
\end{tabular}




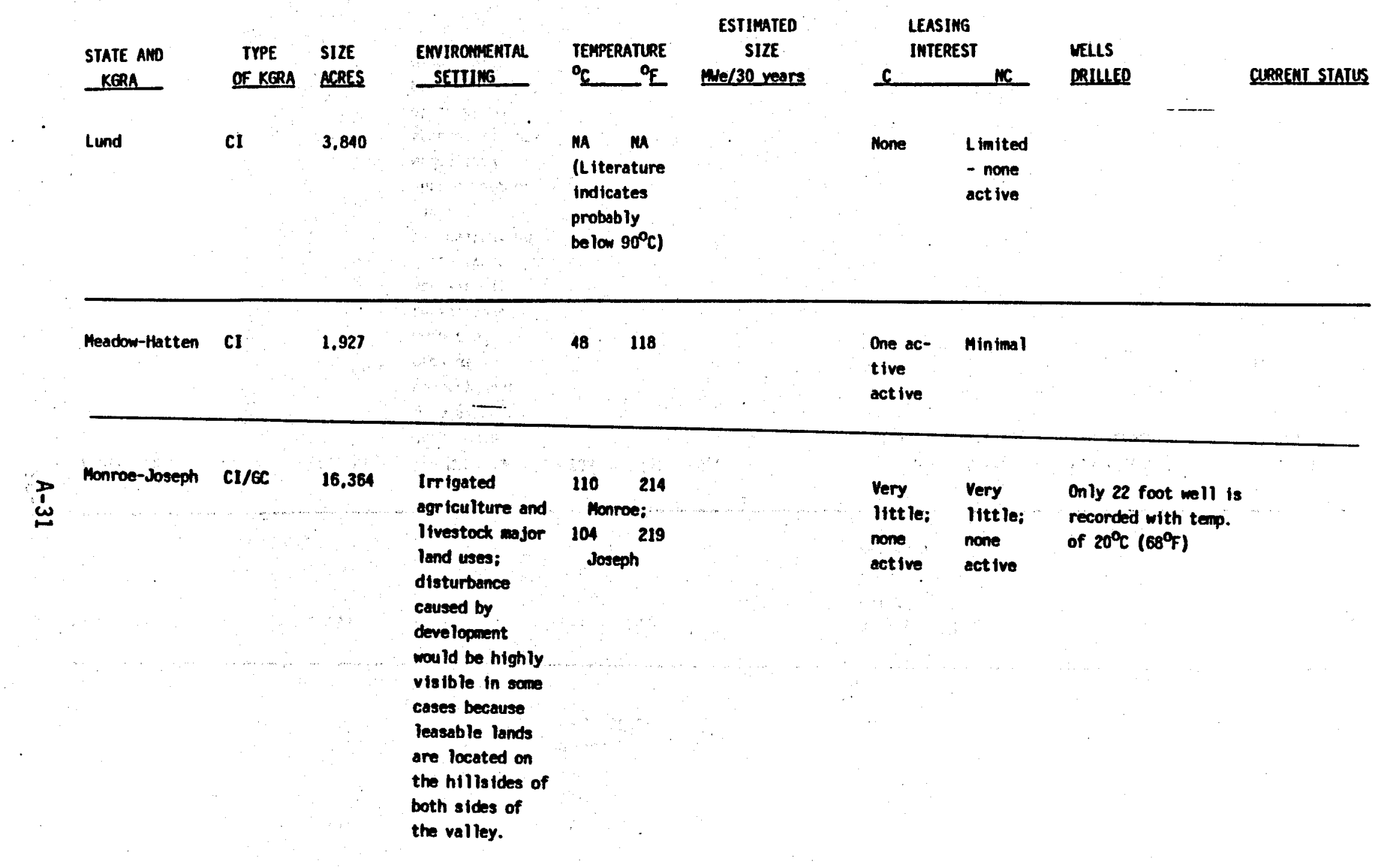




\begin{tabular}{|c|c|c|c|c|c|c|c|c|c|c|}
\hline STATE AMD & TYPE & SIZE & EWIROWHENTAL & TEMPEI & ATURE & $\begin{array}{l}\text { ESTIMATED } \\
\text { SIZE }\end{array}$ & $\begin{array}{l}\text { LEAS } \\
\text { INTEI }\end{array}$ & & MELLS & \\
\hline KERA & Of KGRA & ACRES & SETIING & ${ }^{\circ} \mathrm{C}$ & & me/30 years & $c$ & $M$ & DRILLED & CURREMT STATUS \\
\hline Mavajo Lake & CI & 2.522 & & $\begin{array}{l}\text { MA } \\
\text { (Liter } \\
\text { Indice } \\
\text { probat } \\
\text { below }\end{array}$ & $\begin{array}{l}\text { MA } \\
\text { ture } \\
\text { tes } \\
\text { iy } \\
0^{\circ} \mathrm{C} \text { ) }\end{array}$ & & $\begin{array}{l}\text { No recorc } \\
\text { in this }\end{array}$ & of leases & & \\
\hline Newcast le & CI & 2.636 & & 130 & 200 & & $\begin{array}{l}\text { Only } 1 \\
\text { rel.l } \\
\text { term } \\
\text { recorded }\end{array}$ & None & & \\
\hline Rooseve lt HS & $\cdots$ & 29.791 & $\begin{array}{l}\text { The KGRA is } \\
\text { located in } \\
\text { Utah's "Color } \\
\text { Country" and } \\
\text { provides a } \\
\text { number of } \\
\text { recreat ional } \\
\text { act ivit ies; } \\
\text { Class IV on BLM } \\
\text { VRM system; no } \\
\text { rare, } \\
\text { threatened, or } \\
\text { endangered } \\
\text { species in area } \\
\text { of exist ing } \\
\text { power } \\
\text { development. }\end{array}$ & 265 & 509 & 970 & $\begin{array}{l}-12 \text { ac- } \\
\text { tive }\end{array}$ & $\begin{array}{l}\text { A few } \\
\text { act ive }\end{array}$ & $\begin{array}{l}\text { Full field } \\
\text { deve lopment. }\end{array}$ & $\begin{array}{l}20 \text { and } 14 \text { me } \\
\text { plants on- } \\
\text { line; no new } \\
\text { announced } \\
\text { plans. }\end{array}$ \\
\hline
\end{tabular}




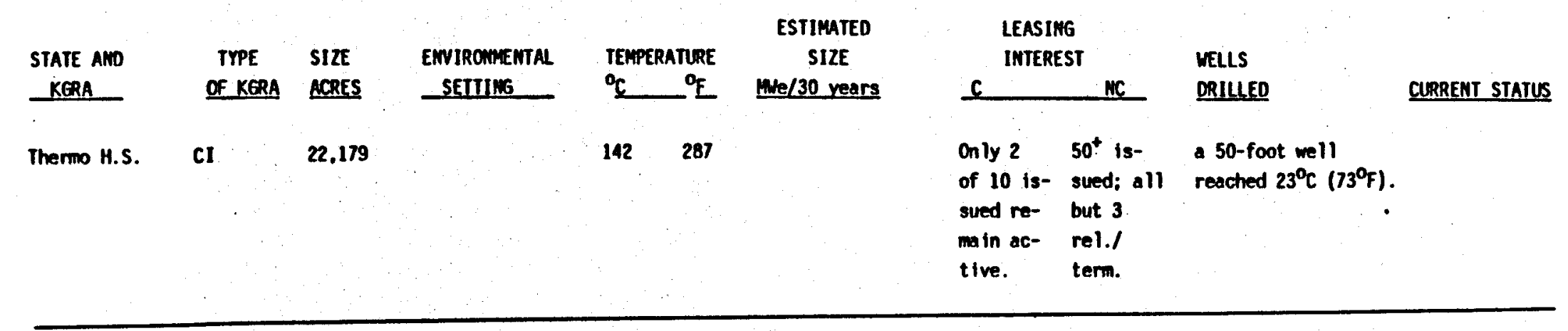

WASHIMGTON

Kennedy HS

Closed to development

since it is

within the

Glac ler Peak

Mi lderness

area.

Mt. St. Helens

Leasing is not permitted in

the Mational

Momment area;

Forest Service

likely to

apply No

Surface

Occupancy

st ipu lat ions

in other

areas. 
APPEADIX B

STATE SUMMARIES

$$
B-1 / \beta-2
$$





\section{APPERDIX B}

\section{STATE SUMMARIES}

\section{ARIZONA}

Clifton and Gillard Hot Springs competitive interest KGRA's, the only ones ever designated in Arizona, have been declassified. Only one competitive lease was issued at clifton and that to a company which is known to be involved in direct use only. It has since been terminated.

Just over 200 noncompetitive applications have been filed for acreage in the state, over a third of which were withdrawn and nearly a third of which were rejected. Many, although not all, were on acreage in National Forests. Twenty-five noncompetitive leases have been relinquished/terminated, and a great many were still pending action when the BLM data base. was concluded.

Five noncompetitive leases near Kaiser and Cofer Hot Springs remain active, and two each near the Hassayampa Plain and northwest of Verde Hot Springs. Pumped wells in the Hassayampa Plain area drilled in connection with direct use feasibility investigations have produced fluids of $35-56^{\circ} \mathrm{C}$ (95$133^{\circ} \mathrm{F}$ ) in temperature at depths between 1,000 and 2,000 feet. In the Kaiser/Cofer area, fluid temperatures of $37^{\circ} \mathrm{C}\left(99^{\circ} \mathrm{F}\right)$ have been found. These temperatures will not support economic power generation with current technology or with R\&D developments envisioned in the foreseeable future.

Thus, in light of combined negative factors, it can be concluded that hydrothermal power generation of any significance cannot be expected in Arizona prior to 2010.

\section{CALIFORNIA}

California embraces 22 active KGRA's, ranging in size from the Mono-Long Valley KGRA with nearly 460,000 acres to Bodie which encompasses only 640 
acres. The latter is a good example of a KGRA formed only because of acreage overlap in noncompetitive lease applications, while Mono-Long Valley was designated early on the basis of geologic indications of a commercial resource.

The major factor that will influence the lease royalty revenue to be derived from this state is land ownership in critical areas. While 57 percent of the total acreage in all California KGRA's is in federal ownership, the percentage varies widely from one area to another. For example, the acreage in the Brawley, Heber, and Westmorland KGRA's in Imperial Valley is virtually all nonfedera1, while the nearby Glamis KGRA is 92 percent federally-owned. It cannot be concluded, however, that Glamis will be a great source of royalty revenue, because, as shown in Exhibit 10, for a number of reasons, significant development in that area is not expected for the foreseeable future. In fact, on the basis of available information, East Mesa, which is 85 percent federally owned, will be the only major source of royalty revenue in the Imperial Valley as long as the current development pattern prevails.

To the contrary, some of the more favorable prospects may return substantial revenues if development proceeds in those areas on a large scale. For example, Coso, where development is occurring, is 94 percent Federallyowned, and Mono-Long Valley is 78 percent Federal. While the small plant operating in the latter area is not using federal resources, several other plants are planned.

This leaves The Geysers KGRA where only 28 percent of the 1 and is federally-owned. Currently, all UNOCAL development is on non-federal 1 and, and only four plants in the area are on Federal leases .. the two Northern California Power Agency plants and those of the Sacramento Municipal Utility District and Santa Fe Geothermal. The Central California Power Agency Cold Water Creek plant and the small (22 MWe) plant of Freeport Geothermal Resources 
Co. are being constructed on private 1and. Except for its Unit 21, to which PG\&E is firmly committed, no other new plants have been announced. That utility and the others with facilities in the area currently have more than enough capacity. However, because of the size of the plants at The Geysers compared to hot water plants, existing and planned, this area will probably continue to be the largest royalty producer for the foreseeable future.

Those KGRA's in California that were not considered likely candidates for power development by 2010 include the following:

Bodie

This KGRA encompasses only 640 acres, and was given KGRA status only because of overlap in acreage applied for in noncompetitive applications. It has received no developer interest.

Brawley/East Brawley/South Brawley

This area is almost exclusively private land, and only one small noncompetitive federal lease is listed for its environs.

Dunes

There are no active leases in the area, and no bids have ever been received at competitive sales. Sale notices announce that the area has been used by the Army and Navy as a bombing area, and the government does not guarantee the area to be free of unexploded bombs or other hazardous materials.

Glamis

The above problems at Dunes also exist at Glamis. 
Heber

This area is almost exclusively private 1 and.

Knoxville

While this KGRA is very close to The Geysers, only one lease has ever been issued for its acreage. No current interest is indicated.

Lassen

The U.S. Forest Service has denied leasing in this area.

\section{$\underline{\text { Saline Valley }}$}

The temperature of the resource is this area $\left(57^{\circ} \mathrm{C}\right)$ would preclude power development with state-of-the-art technology or with any R\&D developments currently envisioned. It is also a small area, and there is no record of any leases being issued.

\section{Sespe Hot Springs}

Although the temperature of geothermal fluids in this area is high and flows substantial, it is extremely isolated and undeveloped. Because of the area's pristine condition and abundant wildlife, geothermal development in the area is untikely.

\section{Salton Sea}

All development envisioned in this area is on nonfederal 1 and.

Wende T-Amedee 
While efforts are underway to boost the low temperatures of the geothermal resource with wood combustion in a hybrid binary system, and one very small binary unit is on-line and another planned, significant power generation for this area cannot be foreseen over the next two decades.

Westmorland

All lands privately owned.

\section{COLORADO}

There are three remaining very small KGRA's in Colorado .. Mineral Hot Springs, Poncha, and Valley View Hot Springs -- all lying within a few miles of each other in south central colorado. All were designated on the basis of competitive interest -- not geologic criteria -.- as was a fourth KGRA, Alamoso County, which has now been declassified.

The level of interest in geothermal leasing in Colorado was never very high, and the record is most notable for the number of noncompetitive applications filed and withdrawn within very brief periods, possibly to serve some tax purpose or other interests not associated with serious development of the resource. The level of interest has now declined to the extent that there are only two active noncompetitive leases and no competitive leases in the entire state. One of the leases is for acreage near the Mineral Hot Springs KGRA and the other is in an area to the north called South Canyon Hot Springs. Both are held by individuals. If their purpose in holding the leases goes beyond speculation, it may be for direct use in which interest is growing in Colorado.

In fact, the only well in Colorado listed on the geothermal drilling records was a 155-foot exploration hole for direct use drilled in Garfield 
County in 1981. No temperature gradient holes or exploratory wells are recorded associated with power generation.

The fluid temperature at Poncha, as estimated by USGS, is $71^{\circ} \mathrm{C}\left(160^{\circ} \mathrm{F}\right)$ and $37^{\circ} \mathrm{C}\left(99^{\circ}\right)$ at Valley View Hot Springs, which represents the temperature data available for colorado. These temperatures will not support power generation with current technology or R\&D developments envisioned for the foreseeable future.

Thus, in light of the combination of negative factors, it can be concluded that Colorado is not a likely candidate for significant geothermal power development by the year 2010 .

IDAHO

Idaho embraces seven KGRA's, but which, for all practical purposes, are reduced to five with the elimination of Island Park and Yellowstone from leasing by statutory prohibition. Of the remaining areas, Raft River, site of earlier DOE binary R\&D experimental operations, has the highest estimated temperature at $140^{\circ} \mathrm{C}\left(284^{\circ} \mathrm{F}\right)$. In descending order, the temperatures of the remaining areas are estimated as follows:

$\begin{array}{lcc} & { }^{\circ} \mathrm{C} & { }^{\circ} \\ \text { Vulcan } & 138 & 280 \\ \text { Bruneau } & 110 & 230 \\ \text { Castle Creek } & 107 & 224 \\ \text { Mt. Home } & 72 & 162\end{array}$

The only two areas in Idaho that appear on the USGS list of identified hydrothermal hot water convection systems with temperatures in excess of $150^{\circ} \mathrm{C}$ $\left(300^{\circ} \mathrm{F}\right.$ ) (USGS Circular. 790 ) are the declassified KGRA area of Crane Creek with an estimated temperature of $163^{\circ} \mathrm{C}\left(325^{\circ} \mathrm{F}\right)$ and Big Creek Hot Springs at $157^{\circ} \mathrm{C}$ $\left(314^{\circ} \mathrm{F}\right)$. The Idaho Department of Water Resources estimated the latter as high 
as $175^{\circ} \mathrm{C}\left(346^{\circ} \mathrm{F}\right)$. At T. $23 \mathrm{~N}, \mathrm{R} .18 \mathrm{E}$, this area is far to the northeast of the southern Idaho systems in wide use for a variety of direct applications.

At the end of September 1986, there were only three active competitive and two active noncompetitive geothermal leases for acreage in the entire state.

While this state can by no means be written off for binary development in the future -. and earlier if there were a need for new power capacity -. no significant degree of power generation is foreseen for Idaho prior to 2010.

MONTANA

Although Montana is large and encompasses four KGRA's, leasing activity has been minimal, and there are no active leases today. No competitive leases resulted from sales at Boulder Hot Springs and Marysville, and leasing is not permitted in Yellowstone. The other KGRA, Corwin Springs, abuts Yellowstone Park and is also in close proximity to a large wilderness area. It will almost certainly be impacted by the new significant thermal features legislation, if not Class I PSD as well, and development of any kind is doubtful. Boulder Hot Springs and Yellowstone were designated KGRA's on the basis of geological criteria. The other KGRA's contain both categories of acreage -- competitive interest and geologic criteria.

Just over 120 noncompetitive applications have been filed, with half of them withdrawn and nearly half rejected. Only six noncompetitive leases were issued.

There are numerous direct uses of geothermal energy in Montana, and fluid temperature information gathered by the Montana Bureau of Mines and Geology indicates that such applications will continue to be the only major use of the resources in the state. For example, representative well temperatures obtained are: 


$\begin{array}{lrr}\text { Alhambra Hot Springs } & 56 & 133 \\ \text { Boulder Hot Springs KGRA } & 136 & 277 \\ \text { Corwin Hot Springs KGRA } & 68 & 154 \\ \text { Ennis Hot Springs } & 94 & 201 \\ \text { Marysville KGRA } & 103 & 217\end{array}$

Thus, it is concluded that geothermal power generation in Montana will not likely occur before 2010 .

NEVADA

Nevada embraces 24 KGRA's, seven of which are reported to be already under development along with an area in Fish Lake Valley on noncompetitive leases. This area will be classified as a KGRA, the old Salt Wells Basin KGRA will be reclassified due to a discovery, and several KGRA's, especially the northernmost ones, are to be declassified due to developer disinterest.

The KGRA's under development or in permitting stages include:

Beowawe

Brady-Hazen

9 MWe Cherron

6 MWe Munson Geothermal

5 MWe Munson Geothermal

Darrough Hot Springs NA Great Smokey Valley Geothermal

Dixie Valley 50 MHe Oxbow Geothermal

San Emidio Desert 2.5 MWe Empire Farms

Steamboat Springs 12.5 MWe Yankee-Caithness Joint Venture

5 MWe Geothermal Development Associates/Ormat

Stillwater-Soda Lake 2.4 Mie Cheuron

1-2 Me Trans-Pacific Geothermal (reported to come on-line in 1987 and to be expanded by 8-9 MWe)

In addition, Steam Reserve, a subsidiary of Amax, is planning a 5 MWe unit on noncompetitive acreage in Fish Lake Valley. Also, while Anadarko announced 
a commercial discovery in the Salt Wells Basin area, capable of at least 30 . WWe using binary technology, no construction plans have been found in the literature.

While there has been little competitive interest in the Darrough Hot Springs KGRA itself, its environs are the "hottest" in Nevada today in terms of noncompetitive leases, with at least 40 in force. The Rye Patch area is another center of noncompetitive interest. On the other hand, interest has decreased in some of the better known KGRA's which are currently under development. In Beowawe, for example, the leasing history indicates that developer interest is currently confined to the area under development. Over a dozen competitive leases have been issued in the KGRA portion of the area, but all except those in Chevron's unit have expired or have been terminated or relinquished. Only two of nearly 30 noncompetitive leases in the immediate environs survive, one in the producing unit itself. Similarly, in Brady-Hazen, only the leases in the Desert Peak area, site of the Chevron plant, remain in force.

The KGRA's under consideration for declassification include Baltazor, Colado, Double Hot Springs, Fly Ranch, Gerlach, Pinto Hot Springs, Soldier Meadow, Trego, and perhaps others.

The KGRA's which seem to have the best potential for development or continued development include:

Beowawe

Brady-Hazen

Darrough Hot Springs (Big Smoky Valley)

Dixie Valley
Kyle Hot Springs

Rye Patch

Steamboat Springs

Stillwater-Soda Lake

While the estimated temperature for Darrough is only $132^{\circ} \mathrm{C}$, the leasing record indicates developer interest, planning and permitting is proceeding on a 
power plant, and BLM strongly supports geothermal development for this area. Overall interest has been low at Kyle Hot Springs, but sufficient acreage is under lease to permit development, and the temperature is favorable for binary operations. Rye Patch is a candidate for flash technology if the temperature estimates are reasonably accurate, and, as noted above, interest is high.

\section{NEW. MEXICO}

The best known KGRA in New Mexico is Baca Location No. 1 where Union 0il explored successfully for a number of years leading to selection of the site for construction of the DOE cost-shared 50 MWe flash plant. Even though the resource production was not sufficient for the large plant, Unocal retains the property, and its wells could conceivably be used for a smaller plant at some time in the future. However, there is very little Federal land involved so the impact on royalties would be minimal.

The only other KGRA with a USGS estimated temperature of over $125^{\circ} \mathrm{C}$ is Lightning Dock at $158^{\circ} \mathrm{C}$. However, Circular 790 does not ascribe a power generation capacity to this area, and the only deep development well -- 7,000 feet drilled in 1985 .. has been abandoned. Fluids from this KGRA are used for commercial greenhouse operation, and one small (<1 MWe) binary unit is operated intermittently to supply power to a greenhouse. So far as is known, there are no plans for additional or larger power generation capacity.

The temperatures of the other KGRA's in the state are not suitable for substantial power generation, although it is understood that a very small binary unit of Rox International operated briefly at Gila Hot Springs on 63$68^{\circ} \mathrm{C}\left(145-155^{\circ} \mathrm{F}\right)$ fluid with little success.

OREGON 
The state of Oregon embraces $12 \mathrm{KGRA}$ 's, al though only four of them are on the USGS Circular 790 list of hot water hydrothermal convection systems with temperatures above $150^{\circ} \mathrm{C}\left(300^{\circ} \mathrm{F}\right)$. These include Alvord (it embraces Mickey Hot Springs and Hot (Borax) Lake area), Crump Geyser, Vale (includes Neal Hot Springs), and Newberry Caldera. This list also includes the Trout Creek area in the far southeast corner of the state. The other eight KGRA's appear on the list of hydrothermal systems with temperatures ranging from $90-150^{\circ} \mathrm{C}$ (194$\left.300^{\circ} \mathrm{F}\right)$.

In attempting to develop power generation development scenarios for the geothermal prospects in Oregon for 1988 to 2010, factors such as their potential thermal capability, exploration status, and environmental acceptability are virtually eclipsed by another consideration -.- the surplus of power in the Pacific Northwest. In addition, overcapacity in neighboring states -e.g., California -- has probably removed the viability of regional markets for geothermal power which have been reported to be the panacea for developers working in the Cascades in Oregon. According to a spokesman for the Oregon Department of Energy, if they proceed to development, they will be dependent on an intrastate or an intraregional market.

There are some indications, according to regional spokesmen, that some additional capacity "may" be needed as early as 1995, but most predict that substantial capacity additions will not be needed until the early 2000 range. The Washington State Energy Office estimates that this prediction will require decisions in the 1993-1996 timeframe on the development scenario. Coal plants will require about 10 years to bring on-1 ine and nuclear 10-12 years. Substantial geothermal exploration will have to occur before then for it to be seriously considered in the planning process, and competitive costs will have to be demonstrated. 
For several reasons, the area of the Newberry Caldera KGRA in Oregon thus far appears to be the most viable candidate for consideration. It is described by knowledgeable geologists as the best geothermal candidate in Oregon, and it is the subject of the most extensive and costly exploration program underway in the Pacific Northwest. GEO Operator Inc. is using the results of four temperature gradient holes drilled on the flanks of the caldera, two of which were cost-shared by DOE, to guide its exploration activities, and has committed itself to drilling a deep production well in the summer of 1988 . The long period of Forest Service indecision over the environmentally sensitive areas has ended with the caldera itself excluded from leasing, and GEO Operator has 170,000 acres under lease to work with.

DOE cost-shared deep gradient holes have also been drilled in the Clackamas area close to Breitenbush and east of Crater Springs. Because of this, Breitenbush has been placed on the list of the more promising areas for development, even though other factors are negative. Major development in the Crater Springs area will be put on hold while BLM studies its potential effects on the hot springs at the bottom of the lake which will reportedly take about four years. However, in a recent decision BLM and the Forest Service have agreed to a request to deepen temperature gradient wells on previously disturbed sites. No adverse effect on Crater Lake or the hydrologic system in the immediate vicinity of the Lake Caldera is anticipated.

The Klamath Falls area may be another possibility for power generation. A Lawrence Berkeley Laboratory model ("Conceptual Model of the Klamath Falls, Oregon, Geothermal Area," R.H. Prucha, et al., 1986) indicates that although the maximum source-water temperature has not yet been encountered, temperatures of $150-190^{\circ} \mathrm{C}\left(300-374^{\circ} \mathrm{F}\right)$ exist somewhere in the system. 
Developer interest has waned considerably in nearly all of the KGRA's in Oregon and their environs except Newberry where over 40 percent of the leases in the state are located, encompassing nearly half of the total acreage under lease. A competitive lease sale is also planned. No active leases remain in Summer Lake, Mt. Hood, Klamath Falls, ànd Lakeview while in Alvord, BelknapFoley, Breitenbush, and Carey, a few leases remain active for several thousand acres.

The environmental setting appears to be a major problem in some areas. One of these is Belknap-foley where 21 percent of the Forest Service acreage approved for leasing carries a No Surface Occupancy stipulation; 43 percent is placed under Substantial Developer Constraints; and the remaining 35 percent is subject to such Unspecified/Substantial Development Constraints "as may be necessary." In the Bend and Crescent Ranger Districts of Deschutes National Forest, noncompetitive leasing is permitted on over 500,000 acres. However, of this total, nearly 70,000 acres will carry the NSO stipulation and the remaining acreage will have other protective stipulations. The "optional" stipulations are sufficiently stringent to give a potential developer considerable pause before the expenditure of money in this area. There has also been considerable dispute over Forest Service lease/no lease decisions for Breitenbush in the past, and caution would be advised on developer requirements there. Mt. Hood is, of course, excluded from geothermal leasing since it lies in the Mt. Hood Wilderness Area.

$\underline{\text { UTAH }}$

Utah became the first state outside of California to have commercial-size hot-water geothermal power generation, and small units which came on-1ine somewhat later are operating on dry steam, the first such application in the U.S. outside The Geysers. However, it appears that, for now, geothermal power 
generation in Utah will be limited to these two sites -- Roosevelt Hot Springs and Cove Fort-Sulphurdale.

The first development at Roosevelt KGRA, located 14.5 miles northeast of Milford in southwestern Utah, began in 1974 when Phillips Petroleum Co. obtained a lease and discovered a hydrothermal reservoir at about 2,000 feet. The fluid temperature is $260^{\circ} \mathrm{C}\left(500^{\circ} \mathrm{F}\right)$. Chevron Resources has since replaced Phillips as field operator. The first Utah Power and Light plant came on line in 1984, and, due to the high temperature, encountered some silica scaling problems that have now been overcome. Subsequently, a second plant at 14 MWe has been put in operation at the site, but Utah Power and Light reports that it does not need additional capacity in the near future.

Also located in southwestern Utah, the Cove Fort-Sulphurdale KGRA was first explored by the Department of Energy and Union 011 Co. The Mother Earth Co. acquired the Union leases and penetrated steam at less than 1,200 feet with a temperature of over $204^{\circ} \mathrm{C}\left(399^{\circ} \mathrm{F}\right)$. Beginning with 3.2 MWe capacity in binary units, the plant is being expanded in increments.

Low temperature and lack of industry interest suggest that the other KGRA's in Utah will not be developed in the foreseeable future as follows:

\section{Crater Hot Springs}

With an estimated temperature of $97^{\circ} \mathrm{C}\left(201^{\circ} \mathrm{F}\right)$, the fluids in this KGRA are not suitable for power generation. In addition, even though there were sufficient noncompetitive lease applications for acreage in this area to warrant a BLM study of the environmental impact of development, none of the leases issued as a result remains active today, and there is only one competitive lease. 
Lund

No temperature estimate was found for Lund, and this area has attracted very little noncompetitive interest, and no competitive. No leases remain active.

Meadow - Hatton

At $48^{\circ} \mathrm{C}\left(118^{\circ} \mathrm{F}\right)$, the fluids in this KGRA are not suitable for power generation. The leasing situation is the same as in Lund.

Monroe - Joseph

Same problems.

Navajo Lake

No record of any leases or temperature estimates.

Newcastle

At $130^{\circ} \mathrm{C}\left(266^{\circ} \mathrm{F}\right)$, the fluids in this area have not attracted developer interest. Only one relinquished/terminated lease is recorded.

Thermo Hot Springs

With a marginal temperature for even binary application, $142^{\circ} \mathrm{C}\left(287^{\circ} \mathrm{F}\right)$, developer interest has waned. Over 50 noncompetitive leases were issued, but only three remain active. Only two competitive leases remain.

\section{WASHINGTON}

Only two KGRA's remain in force in Washington .. Mount St. Helens and Kennedy Hot Springs. Since the latter lies within the Glacier Peak Wilderness 
Area, it is closed to development. Just how much development would be permitted in adjacent areas is open to question. At Mount St. Helens, leasing is not permitted in the National Monument area, and Forest Service approval of surface occupancy of sufficient land in the area outside the Monument to make exploration and development feasible there is another potential impediment. The low level of access to the KGRA's in Washington is borne out by the fact that only one tract in the Indian Heaven KGRA, now declassified, has ever been offered for competitive lease in the state.

Mt. Rainier is the largest of the stratovolcanoes in the Cascades Range, but, as a national park, it is withdrawn from geothermal exploration and development. While areas surrounding the park have been subjected to considerable exploration, the entire Park is listed as a Significant Thermal Feature, so that its environs will be impacted by the restrictions of the new legislation.

The only area in Washington on the USGS table of hot-water hydrothermal convection systems with temperatures in excess of $150^{\circ} \mathrm{C}\left(300^{\circ} \mathrm{F}\right)$ (Circular 790) is the Gamma Hot Springs area, which is in or near the Kennedy Hot Springs KGRA, within the Glacier Peak Wilderness area.

Twenty-six of the 27 noncompetitive leases in effect in December 1985 were for acreage immediately adjacent to the Adams Wilderness Area, in the same general area of the state as Mount St. Helens in the Gifford Pinchot National Forest. Although Mt. Adams is the second largest Quaternary stratovolcano in Washington, the geothermal potential is poorly defined due to the 1 and status which restricts accessibility for assessment activities. In addition to the wilderness prohibition in part of this area, development in the other portion is restricted to projects approved by the Yakima Indian Nation. 
Despite all of the foregoing problems, the Washington State Energy Office remains optimistic that geothermal power development will one day come to Washington where innovative direct use applications are already in operation. It is noted that the favorable findings to the north at Meager Creek in Canada and to the south at Newberry Crater in Oregon indicate that good potential may exist for the Washington portion of the Cascades. While only 30 percent of the land in Washington is Federally-owned, most of that lies along the Cascades range.

Since no exploration activity for power development is currently underway, or planned, so far as is known, no significant source of geothermal royalties from power development on Federal land is expected in Washington by 2010.

\section{WYOMING}

Wyoming is considered to be one of the community of geothermal states largely because of the surface manifestations in Yellowstone National Park. However, leasing is not permitted in the Park and will no doubt be precluded in surrounding areas in Wyoming if development would, in the judgment of the Secretary of the Interior, adversely affect the thermal features of the Park. Congress has already prohibited leasing in the Island Park KGRA in Idaho, which lies just to the west of Yellowstone, for this reason.

Most other areas in Wyoming with geothermal potential appear to be useful only for direct applications, but there are some potential long-range exceptions. For example, maximum oil well bottom hole temperatures of $191^{\circ} \mathrm{C}\left(376^{\circ} \mathrm{F}\right)$ have been recorded in the Washokie and Great Divide Basins; $132^{\circ} \mathrm{C}\left(306^{\circ} \mathrm{F}\right)$ in the Overthrust Belt in Hyoming and $210^{\circ} \mathrm{C}\left(410^{\circ} \mathrm{F}\right)$ in Idaho; and $152^{\circ} \mathrm{C}\left(306^{\circ} \mathrm{F}\right)$ in the Green River Basin. Since at least portions of these areas lie outside the 
hịghly protected Park environs, their potential may be investigated at some time in the future.

Other maximum oil well bottom hole temperatures are not as promising for power development. For example:

\begin{tabular}{lll} 
& ${ }^{\circ} \mathrm{C}$ & \multicolumn{1}{c}{${ }^{\circ}$} \\
Midwest (Salt Creek oilfield) & $50-85$ & $122-185$ \\
Shirley Basin & 60 & 140 \\
Powder River Basin & 135 & 275
\end{tabular}

Wyoming has no designated KGRA's, and thus, the minimal leasing activity which has occurred has all been noncompetitive. No leases remain active today.

In light of the above, it is conceivable that Wyoming might see geothermal power generation at some future time when costs, need for additional capacity, and other external influences are more favorable to expenditures for geothermal exploration. Under present conditions, this would not be expected to occur prior to 2010. 
APPENDIX C

KaRA PROXIES AND DATA

$$
c-1 / c-2
$$





\begin{tabular}{|c|c|c|c|c|}
\hline AREA & TEMP ( $\left.{ }^{\circ} \mathrm{F}\right)$ & DEPTH (KF) & VOL (MW/30 YR) & CLASSIFICATION \\
\hline Coso & 640 & $\begin{array}{l}9,000 \\
3,000\end{array}$ & 650 & $Y V-F 1$ \\
\hline East Mesa & 360 & $\begin{array}{l}3,000 \\
9,000\end{array}$ & 360 & IV-BI \\
\hline Glass Mt. & 392 & & 500 & CS-FL \\
\hline Lake City & 306 & $3 K-9 K$ & 1,490 & $B R-B I$ \\
\hline Mono-Long Valley & 536 & $3 K$ & 2,100 & YV-FI \\
\hline Randsburg & 342 & $\cdots$ & 84 & $B R-B I$ \\
\hline Beowawe & 444 & $3 K-9 K$ & 127 & $B R-F L$ \\
\hline Desert Peak & 440 & $1.6 \mathrm{~K}$ & 157 & $B R-F L$ \\
\hline Darrough H.S. & 270 & -- & $\cdots$ & $B R-B I$ \\
\hline Dixie Valley & 290 & -. & 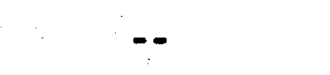 & BR-FL \\
\hline Kyle H.S. & 322 & - & 97 & $B R-B I$ \\
\hline Rye Patch & 423 & -- & $\cdots$ & $B R-F L$ \\
\hline Steamboat Spr. & 403 & $.9 K$ & 350 & YV-F2 \\
\hline Stillwater/SL & 318 & $-\cdot$ & $450+146$ & $B R-B I$ \\
\hline Breitenbush & 260 & -- & -- & $C S-B I$ \\
\hline Klamath Falls & 219 &.- & -- & $C S-B I$ \\
\hline Newberry Caldera & 509 & $3 k$ & 740 & $V V-F 2$ \\
\hline Vale & 370 & $3 K$ & 870 & $B R-B I$ \\
\hline Cove Fort & 509 & $5 K$ & 330 & BR-FL \\
\hline Roosevelt & 509 & $3 K$ & 970 & $B R-F L$ \\
\hline
\end{tabular}

\section{Classification Key}

IV-BI $\rightarrow>$ Imperial Valley Binary $B R-F L \rightarrow>$ Basin and Range Flash $B R-B I \quad->$ Basin and Range Binary CS-FL $\rightarrow$ Cascades Flash CS-BI $-\rightarrow$ Cascades Binary YV-F1 $\rightarrow>$ Young Volcanic Flash 1 YV-F2 $\rightarrow>$ Young Volcanic Flash 2 


\begin{tabular}{|c|c|c|c|c|c|c|c|c|c|}
\hline 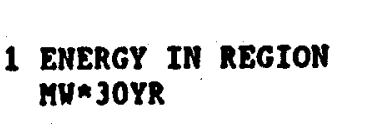 & $\begin{array}{r}\text { EASTMESA } \\
360.0 \\
-14.2\end{array}$ & $\begin{array}{r}\text { BEOUAYE } \\
127.0 \\
-62.3\end{array}$ & $\begin{array}{r}\text { LARECITY } \\
1490.0 \\
-640.7\end{array}$ & $\begin{array}{r}\text { GLASS MT. } \\
500.0 \\
-171.0\end{array}$ & $\begin{array}{r}\text { BREI ' BUSH } \\
300.0 \\
-282.5\end{array}$ & $\begin{array}{r}\text { MONO-LONG } \\
2100.0 \\
-484.5\end{array}$ & $\begin{array}{r}\text { STMBTSPRG } \\
350.0 \\
-80.7\end{array}$ & $\begin{array}{r}\text { DESERTPK } \\
453.5 \\
-222.3\end{array}$ & $\begin{array}{r}\text { RNDSBURG } \\
84.0 \\
-36.1\end{array}$ \\
\hline $\begin{array}{l}2 \text { ENERGY IN SUBAREA } \\
\text { MU*3OYR }\end{array}$ & $\begin{array}{r}86.4 \\
0.0\end{array}$ & $\begin{array}{r}10.4 \\
0.0\end{array}$ & $\begin{array}{r}212.7 \\
0.0\end{array}$ & $\begin{array}{r}54.8 \\
0.0\end{array}$ & $\begin{array}{l}1.5 \\
0.0\end{array}$ & $\begin{array}{r}161.5 \\
0.0\end{array}$ & $\begin{array}{r}26.9 \\
0.0\end{array}$ & $\begin{array}{r}37.0 \\
0.0\end{array}$ & $\begin{array}{r}12.0 \\
0.0\end{array}$ \\
\hline $\begin{array}{l}3 \text { RESERVIOR SATUR. } \\
\text { TEMP. F }\end{array}$ & $\begin{array}{l}360.0 \\
-20.0\end{array}$ & $\begin{array}{l}444.0 \\
-49.3\end{array}$ & $\begin{array}{l}306.0 \\
-20.4\end{array}$ & $\begin{array}{l}392.0 \\
-46.1\end{array}$ & $\begin{array}{r}260.0 \\
-9.3\end{array}$ & $\begin{array}{r}446.0 \\
-18.6\end{array}$ & $\begin{array}{l}403.0 \\
-54.9\end{array}$ & $\begin{array}{l}373.0 \\
-41.4\end{array}$ & $\begin{array}{r}342.0 \\
-22.8\end{array}$ \\
\hline $\begin{array}{l}4 \text { UELLLEEAD } \\
\text { TEMP F }\end{array}$ & $\begin{array}{l}350.0 \\
-20.0\end{array}$ & $\begin{array}{l}394.0 \\
-24.6\end{array}$ & $\begin{array}{l}294.0 \\
-10.2\end{array}$ & $\begin{array}{l}342.0 \\
-59.3\end{array}$ & $\begin{array}{r}250.0 \\
-9.3\end{array}$ & $\begin{array}{r}231.0 \\
-6.0\end{array}$ & $\begin{array}{l}259.0 \\
-19.8\end{array}$ & $\begin{array}{l}323.0 \\
-20.2\end{array}$ & $\begin{array}{r}330.0 \\
-11.5\end{array}$ \\
\hline $\begin{array}{l}5 \text { TOTAL DISSOLVED } \\
\text { SOLIDS, PPK }\end{array}$ & $\begin{array}{l}2.1 \\
0.4\end{array}$ & $\begin{array}{l}1.2 \\
0.8\end{array}$ & $\begin{array}{l}1.5 \\
1.6\end{array}$ & $\begin{array}{l}1.0 \\
1.5\end{array}$ & $\begin{array}{l}0.5 \\
0.5\end{array}$ & $\begin{array}{l}1.5 \\
2.0\end{array}$ & $\begin{array}{l}2.7 \\
1.4\end{array}$ & $\begin{array}{l}2.7 \\
1.7\end{array}$ & $\begin{array}{l}1.2 \\
1.3\end{array}$ \\
\hline $\begin{array}{l}6 \text { UELL DEPTH } \\
1000 \text { FEET }\end{array}$ & $\begin{array}{l}4.2 \\
0.0\end{array}$ & $\begin{array}{l}1.2 \\
0.0\end{array}$ & $\begin{array}{l}4.2 \\
0.0\end{array}$ & $\begin{array}{l}5.0 \\
0.0\end{array}$ & $\begin{array}{l}5.0 \\
0.0\end{array}$ & $\begin{array}{l}4.2 \\
0.0\end{array}$ & $\begin{array}{l}1.9 \\
0.0\end{array}$ & $\begin{array}{l}2.6 \\
0.0\end{array}$ & $\begin{array}{l}5.0 \\
0.0\end{array}$ \\
\hline
\end{tabular}


1 ENERGY IN REGION NW*30YR

2 ETERGY IA SUBAREA MU*JOYR

3 RESERVIOR SATUR. TEMP. $F$

4 VELLHEAD TEHP $F$

\section{TOTAL DISSOLVED} SOLIDS, PPK

6 MELL DEPTH 1000 FEET

\begin{tabular}{rr}
$\begin{array}{r}\text { KLAMRTH } \\
300.0\end{array}$ & \multicolumn{1}{c}{ coso } \\
-282.5 & -150.0 \\
& 5.0 \\
1.5 & 50.0 \\
0.0 & 0.0 \\
338.0 & 543.0 \\
-12.1 & -22.6 \\
328.0 & 328.0 \\
-12.1 & -8.5 \\
0.5 & 2.0 \\
0.5 & 2.7 \\
5.0 & 4.2 \\
0.0 & 0.0 \\
&
\end{tabular}

$$
740.0
$$$$
-170.7
$$

DIXIE yAL.

$$
\begin{array}{r}
300.0 \\
-147.1
\end{array}
$$

5.0
0.0
443.3
-60.4

299.3
-22.9

10.0

5.0

3.6
24.5

459.0

$-19.1$

244.0

$-6.3$

15.0

20.0

4.2

0.0

423.0

$-47.0$

373.0

$-23.3$

1.5

1.0

5.0

0.0
KYLE

97.0

$-41.7$

13.8
322.0 $-21.5$

310.0 $-10.8$

1.2 1.3

5.0

0.0

$\mathfrak{i}$ 


\begin{tabular}{|c|c|c|c|c|}
\hline $\begin{array}{l}1 \text { ENERGY IN REGION } \\
\text { MN*30YR }\end{array}$ & $\begin{array}{r}\text { COVE FORT } \\
330.0 \\
-161.8\end{array}$ & $\begin{array}{r}\text { STILLYATER } \\
298.0 \\
-128.1\end{array}$ & $\begin{array}{r}\text { ROOSEVELT } \\
970.0 \\
-475.5\end{array}$ & $\begin{array}{r}\text { VALE } \\
906.0 \\
-389.6\end{array}$ \\
\hline $\begin{array}{l}2 \text { ENERGY IN SUBAREA } \\
M U * \text { JOYR }\end{array}$ & $\begin{array}{r}27.0 \\
0.0\end{array}$ & $\begin{array}{r}42.5 \\
0.0\end{array}$ & $\begin{array}{r}79.2 \\
0.0\end{array}$ & $\begin{array}{r}129.4 \\
0.0\end{array}$ \\
\hline $\begin{array}{l}3 \text { RESERVIOR SATUR. } \\
\text { TEMP. F }\end{array}$ & $\begin{array}{l}509.0 \\
-56.6\end{array}$ & $\begin{array}{l}320.0 \\
-21.3\end{array}$ & $\begin{array}{l}509.0 \\
-56.6\end{array}$ & $\begin{array}{l}314.7 \\
-21.0\end{array}$ \\
\hline $\begin{array}{l}4 \text { VELLHEAD } \\
\text { TEMP } F\end{array}$ & $\begin{array}{l}459.0 \\
-28.7\end{array}$ & $\begin{array}{l}308.0 \\
-10.7\end{array}$ & $\begin{array}{l}459.0 \\
-28.7\end{array}$ & $\begin{array}{l}302.7 \\
-10.5\end{array}$ \\
\hline $\begin{array}{l}5 \text { TOTAL DISSOLVED } \\
\text { SOLIDS, PPK }\end{array}$ & $\begin{array}{l}1.5 \\
1.0\end{array}$ & $\begin{array}{l}1.2 \\
1.3\end{array}$ & $\begin{array}{l}7.8 \\
5.1\end{array}$ & $\begin{array}{l}1.2 \\
1.3\end{array}$ \\
\hline $\begin{array}{l}6 \text { KELL DEPTH } \\
1000 \text { FEET }\end{array}$ & $\begin{array}{l}5.9 \\
0.0\end{array}$ & $\begin{array}{l}5.0 \\
0.0\end{array}$ & $\begin{array}{l}3.7 \\
0.0\end{array}$ & $\begin{array}{l}4.2 \\
0.0\end{array}$ \\
\hline
\end{tabular}

? 


\section{APPERDIX D}

IMGEO CALCULATED COSTS

(SPECIFIC AND GENERAL) 


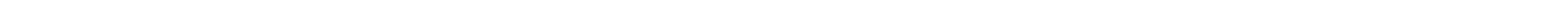


IMGEU ACCUUNTS-DY-DLTE CUST UE RUNEK URIA

EASTKESA BEOUAYE LAKECITY GLASS MT. BREI'BUSH MONO-LONG STMBTSPRG DESERTPK

BASE CASE VALUE, MILLS/KWH

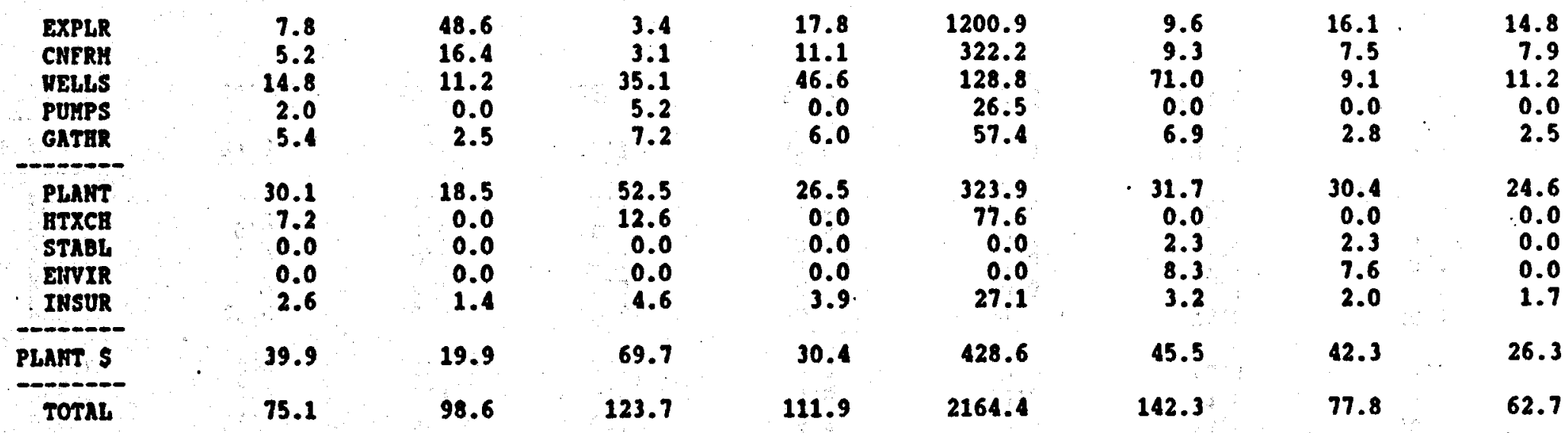

1008 RED VALUE, MILS/KMH

兄

\begin{tabular}{l} 
EXPLR \\
CHFRH \\
UELLS \\
PUIPS \\
GATHR \\
\hline PLANT \\
ETXCR \\
STABL \\
ENVIR \\
INSUR \\
\hline PLANT S \\
\hline TOTAL
\end{tabular}

$\begin{array}{rr}6.4 & 41.3 \\ 4.5 & 14.1 \\ 8.3 & 7.9 \\ 1.4 & 0.0 \\ 3.3 & 2.0 \\ 22.9 & 17.8 \\ 7.0 & 0.0 \\ 0.0 & 0.0 \\ 0.0 & 0.0 \\ 1.8 & 1.1 \\ 31.7 & 18.9 \\ 55.6 & 84.2\end{array}$

2.8
2.7
17.9
3.5
3.9
38.6
11.8
0.0
0.0
3.0
53.4
84.2

14.9
9.4
31.4
0.0
4.7
24.9
0.0
0.0
0.0
2.8
27.7
88.1

482.5

133.2

38.8

14.3
8.1
7.8
40.1
0.0

0.0
3.5

124.8
38.0

0.0

0.0
9.7

31.5

31.5
0.0

2.3

8.3

2.8

172.5

44.9

850.9

104.4

13.6
6.4
6.7
0.0
2.3

12.6

6.8

7.9

0.0

29.9

0.0

2.3

7.6

1.8

24.0

0.0

0.0

0.0
1.4

41.6

25.4

84.2

88.1

70.6

54.7 
IMGEO ACCOUNTS-BY-SITE COST OF POHER DATA

RNDSBURG KLAMATH COSO NEVBERRY DIXIE VAL. DARROUGH GEYSERS RYE PATCH

BASE CASE VALUE, MILLS/KUH

\begin{tabular}{lrrr} 
EXPLR & 32.6 & 196.4 & 20.5 \\
CHFRH & 11.0 & 54.7 & 11.9 \\
UELLS & 21.8 & 11.6 & 71.0 \\
PUMPS & 3.2 & 2.4 & 0.0 \\
GATHR & 4.0 & 2.4 & 6.9 \\
\hline PLANT & 35.5 & 34.2 & 23.0 \\
RTXCH & 8.5 & 8.2 & 0.0 \\
STABL & 0.0 & 0.0 & 2.3 \\
ENVIR & 0.0 & 0.0 & 8.3 \\
IRSUR & 2.9 & 2.5 & 2.8 \\
\hline PLAMT \$ & 46.9 & 44.9 & 36.4 \\
\hline TOTAL & 119.5 & 312.4 & 146.7
\end{tabular}

8.6
5.6
9.1
0.0
2.8

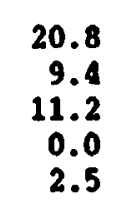

27.0

0.0

2.3

7.6

1.9

38.8

64.9

31.4

0.0

0.0

0.0
2.0

33.4

77.3

.8
.4
.0
.5
.4
.0
.0
.0
.0
.4
.3

21.3

7.9

86.2

12.8

23.5

120.1

28.8

0.0

0.0
11.1

160.0

311.7

17.1

10.1

40.1

0.0

3.5

22.8

0.0
2.3

8.3

2.3

35.7

37.2

88.9

36.4

249.7

106.5

7.2
4.8
6.7
0.0
2.3
26.4
0.0
2.3
7.6
1.7
38.0

17.7

8.1

7.9

0.0
2.0

14.5
5.9

5.9
38.5

7.6

7.6
10.9

31.0

31.0
0.0

0.0

0.0

76.6

76.6
23.3

0.0

0.0

32.8

106.2

68.5

183.6

9.2
8.1
40.1
0.0
3.5
30.4
0.0
2.3
8.3
2.7
43.7

11.0
9.6
71.0
0.0
6.9
30.5
0.0
2.3
8.3
3.2
44.3
142.8

21.6

9.6

11.2
0.0

2.5

20.3

0.0

0.0

0.0
1.5

21.8

66.7

59.0

104.6
18.3

8.3

7.9

2.0

19.7

0.0

0.0
0.0

1.2

20.9

57.4 
IMGEO ACCOUNTS-BY-SITE COST OE PONER DATA

KYLE COVE FORT STILLUATER ROOSEVELT VALE

BASE CASE VALUE, MILLS/KUn

\begin{tabular}{|c|c|c|c|c|c|}
\hline $\begin{array}{l}\text { EXPLR } \\
\text { CRFRM } \\
\text { UELLS } \\
\text { PURPS } \\
\text { GRTAR }\end{array}$ & $\begin{array}{r}33.2 \\
11.1 \\
27.6 \\
4.1 \\
5.3\end{array}$ & $\begin{array}{r}19.3 \\
9.0 \\
11.1 \\
0.0 \\
2.5\end{array}$ & $\begin{array}{r}10.9 \\
5.1 \\
28.2 \\
4.2 \\
5.5\end{array}$ & $\begin{array}{r}8.2 \\
6.2 \\
11.1 \\
0.0 \\
2.5\end{array}$ & $\begin{array}{r}4.6 \\
3.4 \\
30.5 \\
4.5 \\
6.1\end{array}$ \\
\hline $\begin{array}{l}\text { PLANT } \\
\text { BTXCR } \\
\text { STABL } \\
\text { ENVIR } \\
\text { INSOR }\end{array}$ & $\begin{array}{r}43.0 \\
10.3 \\
0.0 \\
0.0 \\
3.6\end{array}$ & $\begin{array}{r}16.5 \\
0.0 \\
0.0 \\
0.0 \\
1.3\end{array}$ & $\begin{array}{r}44.0 \\
10.5 \\
0.0 \\
0.0 \\
3.7\end{array}$ & $\begin{array}{r}16.5 \\
0.0 \\
0.0 \\
0.0 \\
1.3\end{array}$ & $\begin{array}{r}47.3 \\
11.3 \\
0.0 \\
0.0 \\
4.0\end{array}$ \\
\hline PLint \$ & 56.9 & 17.8 & 58.2 & 17.8 & 62.6 \\
\hline TOTAL & 138.2 & 59.7 & 112.1 & 45.8 & 111.7 \\
\hline
\end{tabular}

1008 RED VALUE, MILLS/KUH

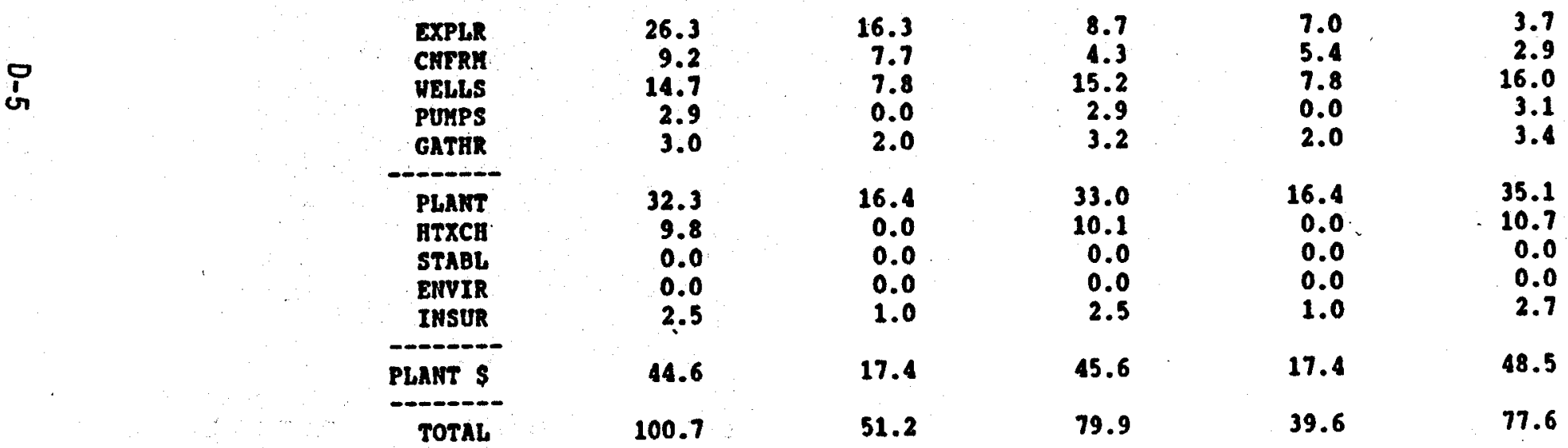




\begin{tabular}{|c|c|c|c|c|c|c|c|c|c|}
\hline $\begin{array}{l}1 \text { BASE CASE COST- } 1987 \\
\text { YEAR ON LINE }\end{array}$ & $\begin{array}{r}\text { EASTHESA } \\
7.53 \\
1998\end{array}$ & $\begin{array}{r}\text { BEOWAYE } \\
9.87 \\
1998\end{array}$ & $\begin{array}{r}\text { LARECITY } \\
12.36 \\
2004\end{array}$ & $\begin{array}{r}\text { GLASS RT. } \\
11.19 \\
2002\end{array}$ & $\begin{array}{r}\text { BREI ' BUSH } \\
216.4 \\
N / A\end{array}$ & $\begin{array}{r}\text { MONO-LONG } \\
14.22 \\
2005\end{array}$ & $\begin{array}{r}\text { STMBTSPRG } \\
7.79 \\
1994\end{array}$ & $\begin{array}{r}\text { DESERTPK } \\
6.28 \\
1990\end{array}$ & $\begin{array}{r}\text { RNDSBURG } \\
11.95 \\
2003\end{array}$ \\
\hline $\begin{array}{l}2 \text { COST OF POHER - } \\
\text { H/100\& RED BY } 2000\end{array}$ & 5.57 & 8.42 & 8.42 & 8.81 & 85.09 & 10.44 & 7.07 & 5.47 & 8.89 \\
\hline $\begin{array}{l}\text { EARLIEST YR OH LINE } \\
\text { H/ OR H/O RED }\end{array}$ & 1997 & 1997 & 2000 & 2000 & $H / A$ & 2002 & 1993 & 1990 & 2000 \\
\hline
\end{tabular}

$\dot{\circ}$ 
1 BASE CASE COST- 1987
YEAR ON LINE

2 COST OF POWER -

W/1008 RED BY 2000

EARLIEST YR ON LINE

W/ OR H/O RED
KLAKATH

31.2

24.97

$\mathrm{N} / \mathrm{A}$

\section{coso}

14.66

2005

10.65

2002

\section{DIXIE VAL. DARROUGH}

7.75

6.49
2003

2003

1994

6.84

1993

2001
GEYSERS

14.27

31.18

18.37

10.46

2002

RYE PATCH

6.67

1991

RYLE

13.83
2005

5.73

10.06

1991

2000 
1 BASE CASE COST- 1987 YEAR OH LINE

2 COST OF POUER -

W/100\% RED BY 2000

EARLIEST YR ON LINE

W/ OR W/O RED

\begin{tabular}{rrrr} 
COVE FORT & \multicolumn{1}{c}{ STILLWATER } & ROOSEVELT & \multicolumn{1}{c}{ VALE } \\
5.96 & 11.21 & 4.58 & 11.17 \\
1998 & 2001 & 1992 & N/A \\
5.13 & 8 & 3.96 & 7.78 \\
& & & \\
1997 & 1997 & 1991 & 2007
\end{tabular}


APPENDIX E

AYOIDED COST INFORMATION

$$
E-1 / E-2
$$





\section{Appendix E}

\section{California}

The state of California, through the California Energy Commission, provided unofficial avoided cost rates from The Economic Impacts of Self Generation: March 1987 - Staff Report for the California Energy Commission (C.E.C.). These figures were forwarded to us from the C.E.C. Economist, Mr. Sandy A. Miller. The figures used evolved from a weighted average of the three utilities for the state. The inflation rate average from these three tables was $5.63 \%$ and the escalation rate from 1990 to 2010 was $9 \%$.

The following pages contain the data used for the avolded cost estimates. 


\section{California}

\section{Weighted Averages}

\section{YEAR}

1987

1988

1989

1990

1991

1992

1993

1994

1995

1996

1997

1998

1999

2000

2001

2002

2003

2004

2005
c/kWh

WEIGHTED AVG.

2.42

2.84

3.74

3.95

4.35

4.75

5.19

5.69

6.06

6.64

7.23

7.89

8.66

9.34

10.18

11.17

12.13

13.49

14.76 


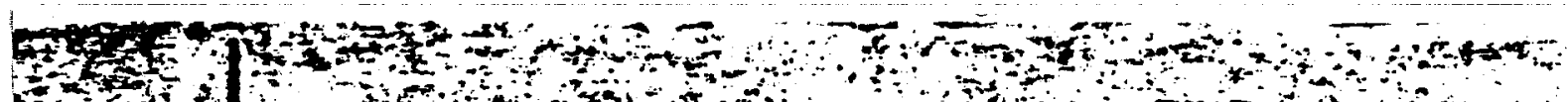

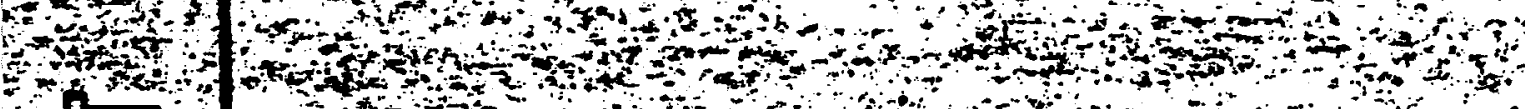

(1)

$3=x^{2}+2$

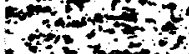

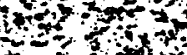

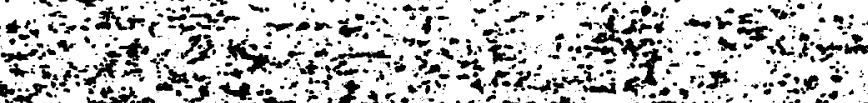

aes

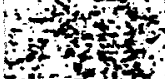

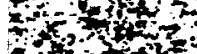

(

$\longrightarrow$

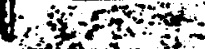

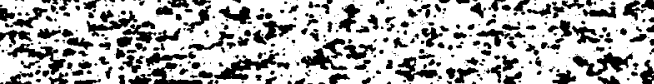

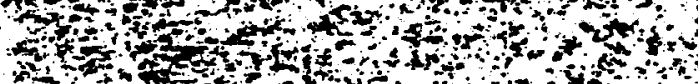

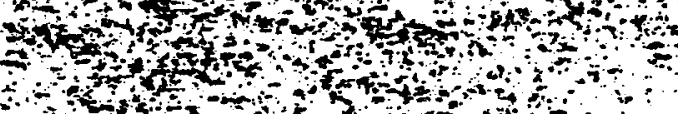

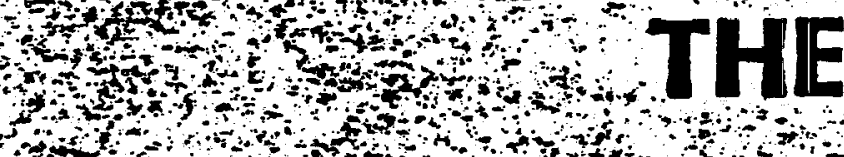

ECONOMIC

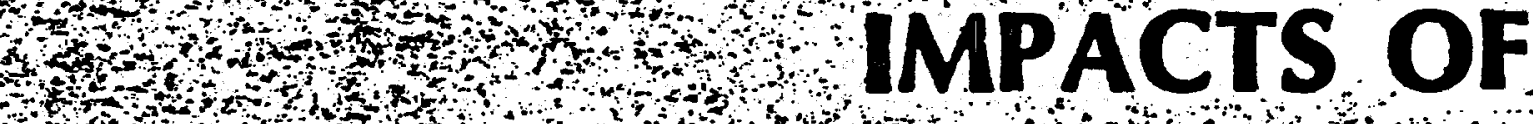

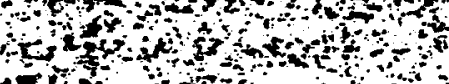

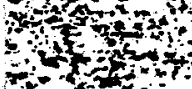

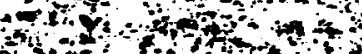

SELF GENERATION

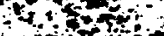

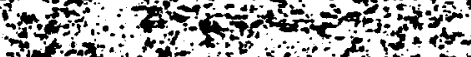

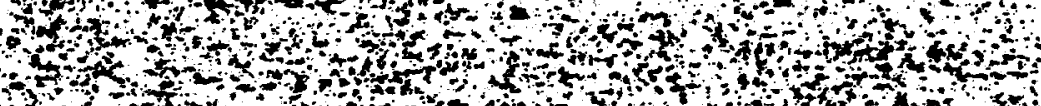

at.

ation

inting

3

[ن

ons

$1+\frac{1}{2}$

ind

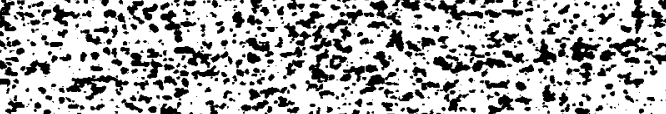

$2+3$

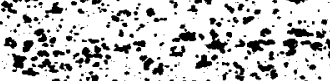

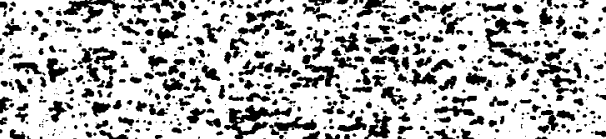

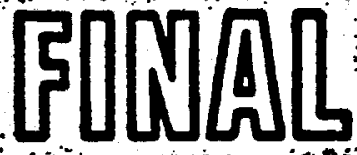

\section{ats

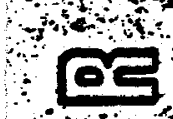

$+7$

ritis

and

intos?

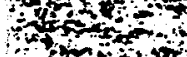

witis

$\mathrm{n}+2$

intons

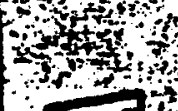

25

$=3 x+400$

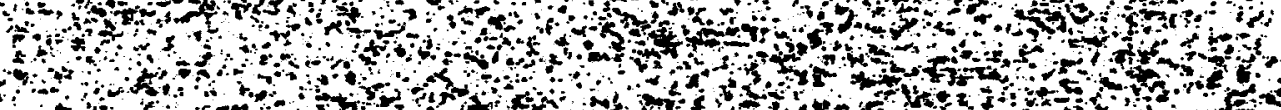

top

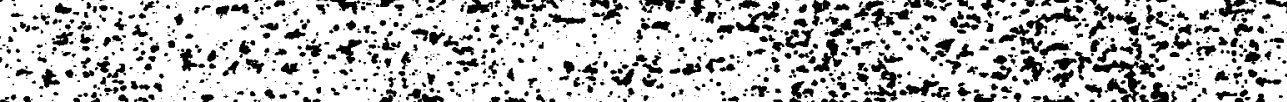

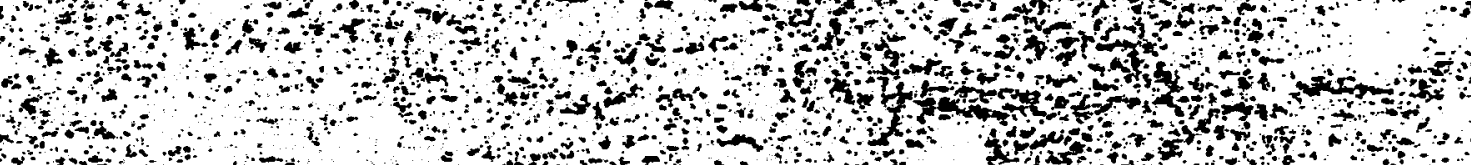

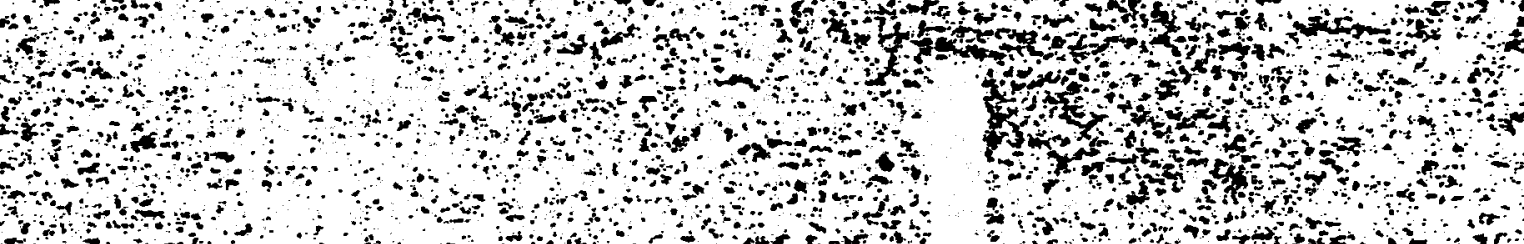

40

$+x+y+3$

tots

Rim

and

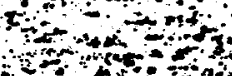

$x^{2}+4=0$

and

$\operatorname{los}_{0}$

ind

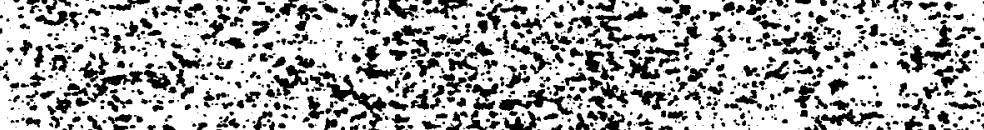

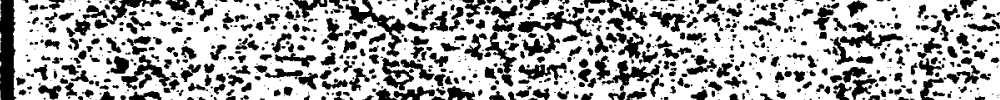

(1)

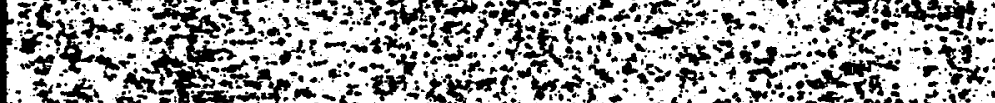

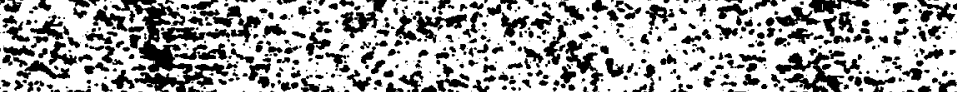

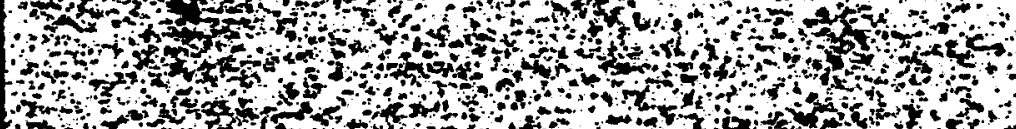

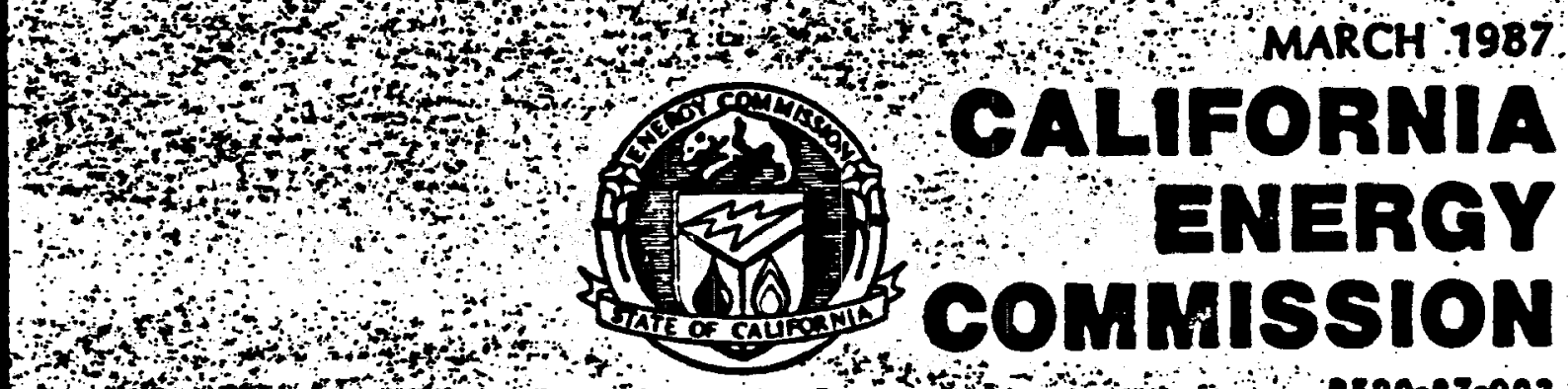

ing

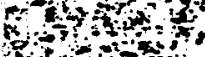

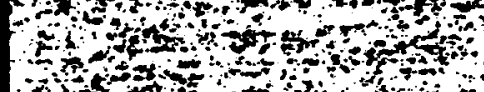

e.

-

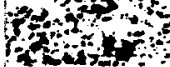

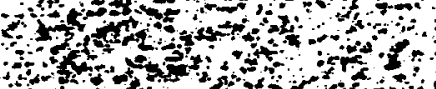

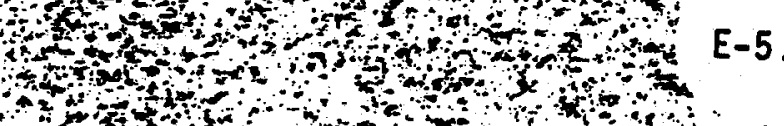

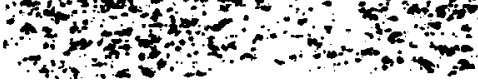

32

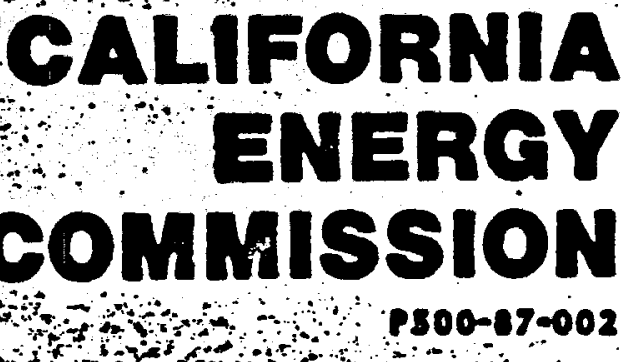


auspended. The CPUC will socn begin coupliance proceedings to implenent the inethodology to calculate long-term avoided costs and to develop another long-term contract offer.

b. Standby Rates

Standby rates are charged OFs or self-generators to be eligible for backo utility eervice. Backp utility service may be very important to self-generators requiring higher reliability. If and when standby utility eervice is provided, nomal tariff charges exply.

Although the Cruc has previously reguired the utilities to provide standby service at nominal zates (\$1/k\%/manth for SCE [ScE, Cal P.U.C. Sheet No. 6042-E, Effective Hay 12, 1982] which may be waived for high capacity factor of cogeneration), Its recent general rate case decision for SDGEE (SDGEE, Cal P.U.C. Sheet No. 5613-19-E, Effective Jamury 1, 1986). apgears to signal a trend towerds higher standoy rates. Stariby charges for SDGSE are now $\$ 5 / \mathrm{s} / \mathrm{month}$, based on the Cruc public taff's proposal using avolded cost principles. There are incentives for rechucing aither the dewand charge or the standby charges. 'If the custcmer maintains at least a 50 percient capacity factor during on paak periods in the previous 12 months, nowmal demand charges are wafved. If an 85 percent an-peak capacity factor is attained orring the billing period, coclusive of maintenance, or If the custamer facing time-of-ise standby avoids using utllity power curring peak periods as specified by the schectule, the standby charge is rechuced to $\$ 2.50 / 35 /$ month.

SDGeE offers interinutible standby cervice with no minimm charge for customers with total load greater than 500ks.

In Its arrent general rate increase application for test year 1987 (PCandE, Cal P.U.C. Ehaet No. 839-E, Effective January 1, 1984), Feards is proposing a standby charge of $\$ 4.25 / \mathrm{KN} /$ manth. Whis compares with an $\$ 0.80 / \mathrm{k} / \mathrm{month}$ standoy zate charged presently.

c. Avolded cost Forecasts

The forecasted energy and capacity portions of avoided costs for PGandE, SCE, and SDGEE vere calculated from preliminary EFW nus using the data input illes developed by the Cxc contractors, Bill Iroxisen of Raiser Engineers and Dd Kahn. These preliminary forecasts (Tables 20-25) were used by staff in 
performing the cashflow analysis for the various selfgeneration facilities. Die to time constraints, it was not possible to undertake an iterative approach, whereby the cashflow analyses would be redane to reflect any later updated forecasts generated by cxc staff. However, the analysis of self-generation facilities was intended to develop a general picture of the selfgenerators and was not intended to provide the definitive answer of what the economics of selfgeneration will be.

Table 20

PGande AWOIDID COST ENERGY SERIISS

(Milis/sin)

\begin{tabular}{ccc} 
Year & (argent S) & 1986 S) \\
\hline 1987 & & 20.89 \\
1988 & 22.1 & 22.87 \\
1989 & 25.6 & 26.68 \\
1990 & 31.6 & 28.65 \\
1991 & 35.9 & 30.13 \\
1992 & 39.9 & 30.86 \\
1993 & 43.2 & 32.40 \\
1994 & 47.9 & 34.53 \\
1995 & 53.9 & 34.06 \\
1996 & 56.1 & 34.82 \\
1997 & 60.5 & 36.15 \\
1998 & 66.2 & 36.58 \\
1999 & 70.6 & 37.98 \\
2000 & 77.2 & 39.34 \\
2001 & 84.2 & 40.91 \\
2002 & 92.1 & 42.26 \\
2003 & 100.1 & 43.87 \\
2004 & 109.2 & 46.52 \\
2005 & 121.7 & 48.27
\end{tabular}


Table 21

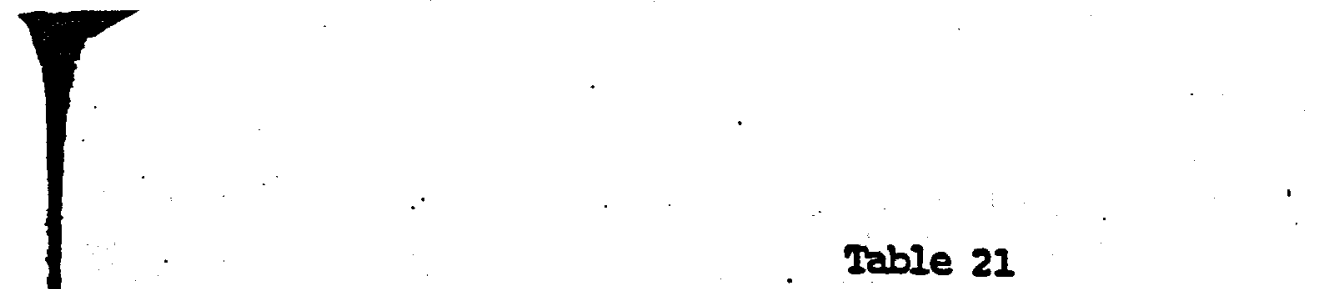

Year

1987

1988

1989

1990

1991

1992

2993

1994

1995

1996

1997

1998

1999

2000

2001

2002

2003

2004

2005

FGande

AWOIDED COST CAPACILY

(\$/ $\mathrm{sm})$

(ament S)

Constant

0

9.28

20.40

32.78

45.63

58.95

82.13

88.63

105.07

210.85

116.83

123.15

129.67

236.55

143.64

151.12

258.82

166.92

175.27

1986 SI

0

8.29

17.23

26.16

34.45

42.11

50.40

56.78

63.80

63.80

63.80

63.80

63.80

63.80

63.80

63.80

63.80

63.80

63.80 
Table 22

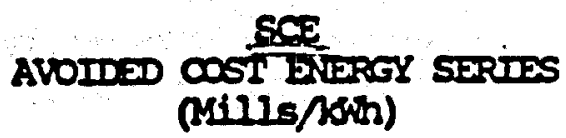

Yar

464 IN

(annent S)

(Canstant

1986 S)

1987

26.3

1988

30.4

36.5

42.3

45.7

50.7

54.7

58.8

64.2

70.5

78.2

86.0

95.2

1999

2000

102.2

211.2

122.9

134.2

148.9

24.86

27.16

30.82

33.76

34.54

36.22

37.00

37.67

38.92

40.58

42.70

44.55

46.84

47.75

49.39

2002

2003

2004

163.6

51.89

53.87

56.91

2005

59.55 
Table 23

\section{Sce \\ AWOIDED COST CAPACTIY \\ (\$/Kw In arrent \$)}

Year

1987

1988

1989

1990

1992

1992

1993

1994

1995

1996

1997

2998

1999

2000

2001

2002

2003

2004

2005 (arrent S)

0

9.95

19.99

31.17

44.71

59.71

77.49

99.86

127.31

254.37

162.71

171.50

180.59

290.16

200.04

210.45

221.18

232.46

244.09 constant

1986 S)

0

8.89

16.88

24.88

33.76

42.65

52.42

63.97

77.30

88.85

88.85

88.85

88.85

88.85

88.85

88.85

88.85

88.85

88.85 


\section{Table 24}

SDGEE

\section{AVOIDED COST ENIXRGY SERTIS \\ (Mi11s/14tin)}

Year

1987

1988

1989

1990

1991

1992

1993

1994

1995

1996

1997

1998

1999

2000

2001

2002

2003

2004

2005 (angent s)

27.4

32.5

37.6

46.3

50.0

53.5

57.8

62.2

67.5

71.6

77.0

83.6

94.2

99.7

105.7

114.5

121.2

129.0

137.8
(Constant

1986 SI

25.90

29.03

31.75

36.95

37.75

38.22

39.20

39.85

10.99

41.21

42.05

43.31

46.35

46.58

46.95

48.34

48.65

49.31

50.16 
Table 25

$$
\begin{aligned}
& \text { SDEEE } \\
& \text { AVOIDED COST CAPACIIYY } \\
& \text { ( } \$ / N N \text { ) }
\end{aligned}
$$

\begin{tabular}{l} 
Year \\
\hline 1987 \\
1988 \\
1989 \\
1990 \\
1991 \\
1992 \\
1993 \\
1994 \\
1995 \\
1996 \\
1997 \\
1998 \\
1999 \\
2000 \\
2001 \\
2002 \\
2003 \\
2004 \\
2005
\end{tabular}

(aranent S)

(Carstant 1986 5)

$$
\begin{array}{r}
18.26 \\
41.27 \\
68.75 \\
98.29 \\
103.90 \\
109.82 \\
115.97 \\
122.46 \\
129.20 \\
136.31 \\
143.67 \\
151.43 \\
159.45 \\
167.91 \\
176.63 \\
185.82 \\
195.29 \\
205.26 \\
215.52
\end{array}
$$

27.26

36.87

58.05

78.45

78.45

78.45

78.45

78.45

78.45

78.45

78.45

78.45

78.45

78.45

78.45

78.45

78.45

78.45

78.45 
Nevada

The Public Utility Commissions' Economist - Ms. Cynthia Mitchell provided the latest avoided cost rate and escalation figure for Northern Nevada. The avoided cost, based on coal, is 5.5 cents/kWh with an escalation figure of $5.557 \%$. The following page 1 ists the prices for each year. 


\section{Nevada \\ Meighted Averages}

YEAR

1987

1988

1989

1990

1991

1992

1993

1994

1995

1996

1997

1998

1999

2000

2001

2002

2003

2004

2005

2006

2007

2008

2009

2010
c/kWh

WEIGHTED AVG.

5.51

5.81

6.13

6.47

6.83

7.21

7.61

8.03

8.48

8.95

9.45

9.97

10.52

11.10

11.70

12.35

13.04

13.76

14.52

15.33

16.18

17.08

18.03

19.03 


\section{Oregon}

The avoided cost information was sent to us by W.A. McNamee, an economist with the Public Utility Commission. The avoided cost rates used for the study are weighted averages from the three utilities within the Oregon service area. The inflation rate used is $4.5 \%$ with the escaltion rate average from 1990 to 2010 at $9.4 \%$. 
Oregon

Weighted Averages

YEAR

1987

1988

1989

1990

1991

1992

1993

1994

1995

1996

1997

1998

1999

2000

2001

2002

2003

2004

2005

2006

2007

2008

2009

2010
t/kWh

WEIGHTED AVG.

1.32

1.44

1.56

1.66

1.76

1.93

2.03

2.26

2.40

3.50

3.76

5.43

5.68

5.89

6.11

6.37

6.63

6.98

7.29

7.56

8.03

8.39

8.74

9.06 
AVOIDED COST INFORMATION

Filed With

Public Utility Commission of Oregon

\section{PORTLAND GENERAL ELECTRIC COMPANY}

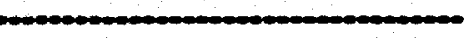

Effective July 1, 1987 


\section{Introduction}

Portland General Electric Company's (PGE) 1987 avoided cost study is presented in two sections which incorporate information required by the rules and regulations of the Oregon Public Utility Commission. Section I - Eleetric Utility System Cost Data is prepared according to OAR 860-29-080(2). The information in this section of the study consists of estimates of resources and resource costs incurred to meet future energy needs on the PGE system. Section II - Avoided Costs and PUC Informational Tables summarizes and expands the information from Section 1 in order $t 0$ deseribe and estimate the power purchase prices based on avoided costs.

Projected electric utility costs are the basic information from which avoided costs are calculated. Avoided costs are "- the incremental costs to an electric utility of electric energy or capacity or both which, but for the purchase from the qualifying facility or qualifying facilities, the utility would generate itself or purchase from another source-, OAR 860-29-010(1). Avoided costs are calculated from estimated future year-by-year utility system costs. These cost estimates are intended to represent overall PGE system power supply costs which can be saved in the future because power is available from substitute resources. Therefore, the avoided costs applieable to any specific substitute resource are dependent on the power production characteristics of that resource compared to the system supply costs. 
Section I

PGE SYSTEM COST DATA

PGE system cost data are summarized in Tables 1 and 2 . Table 1 on Page 5 is an estimate of avoided energy costs by calendar quarter for five years beginning in 3rd quarter, 1987. The average annual avoided energy costs range between 1.6 and 2.2 cents per $\mathbf{k W h}$ expressed in then current year dollars.

Table 2 on Page 6 is a sumary of planned plant additions and potential firm capacity purchases. PGE's forecast of power needs shows that an additional resource is anticipated in $1996 / 97$ to meet projected load requirements under critical water planning criteria. Plant additions are based on matching PGE's expectation of future loads with the contribution of existing and unavoidable future resource additions and avoidable resources. The projections of avoidable resource additions represent the lowest cost alternatives reasonably available to PGE.

The following sections provide additional information and the assumptions used to develop Tables 1 and 2.

\section{Load Forecast}

The avoided energy cost analysis is based on forecast retail loads and existing PGE firm wholesale power commitments. Load levels include estimated, nonfirm sales for resale. System generating resources and purchases of energy are nsed to supply retail loads, firm wholesale loads and any nonfirm loads that can be economically served.

\section{Avoided Costs}

\section{Avoided Energy Costs}

Trble 1 contains estimates of avoidable system energy costs expressed in cents/kWh for each calendar auerter of the five-year period 1987 through 1992 . Avoided energy costs are based on a comparison of two power cost model simulations: a base case simulation and a second simulation with loads 10 average megawatts (mW) lower than the base case. The difference in total costs between the base case and the decremental load case measures the energy costs that are poteatially avoided when qualifying facility power is substituted for other PGE power resources. The power costs incurred to meet both the base and the 10 megawatt load decrement cases are calculated to reflect typical or expected costs. These power cost estimates are based on simulated system operations reflecting 106 years of hydrological dats. The model also evaluates the availability of energy to PGE from other utilities and makes appropriate economy purchases of this energy. Avoided energy costs are derived by calculating the difference in power costs between the base case and the alternative case (which has the $10 \mathrm{mWa}$ load reduction) and then dividing the doller difference by the land change.

Estimated avoided energy costs shown in this filing may deviate from actual avoided costs as actual load and resource conditions deviate from assumptions used in the forecast. At the beginning of each calendar quarter, PGE submits to the PUC, in accordance with OAR 860-29-080(2) supplemental avoided energy cost 
information for the upeoming quarter which reflects the then curreat power supply conditions.

\section{Avoidable Resource Additions}

Table 2 describes planned and potential additions to PGE's energy and capacity resource base necessary to meet load during the time horizon of this filing. The group of qualifying facilities and the Capacity/Energy Exchange are not avoidable resources because PGE has no ability to replace these resources with new qualifying fecility resources.

PGE's next avoidable resource is a facility producing energy and capacity which has an 1996 in-service date. PGE's projected load/resource balance shows a deficiency in energy delivery capability in 1997 and a capacity deficiency in 1996. The load/resource balance projects total system resource capabilities based on adverse hydro supply conditions. Under normal hydro conditions, the PGE system can meet load requirements beyond the 1996/97 dates noted above.

A combustion turbine facility (CT) is used in this filing as a proxy for any resource options and technologies that will be available to PGE as the actual need for resource additions approsches. PGE's actual choice of resources, whether from qualifying facilities, load management and conservation programs, power purchases, industrial cogeneration or power plant additions and improvements is intended to be the least cost source of power required to meet the loads and reliability requirements of PGE's customers. The cost computations in this filing are consisteat with this approach.

The costs of the avoidable resource are based on construction cost estimates of CT facilities prepared by the Northwest Power Planning Council.

Inclusion of the CT resource as the avoidable resource does aot represent a commitment to the installation of such a facility. PGE has no current plans for construction of any particular teehnology. The Company has full flexibility with regard to the plant and does not have to make any construetion decisions for many years. Construction schedules, budgets, and siting considerations are not a part of this study. The CT fuel and $O$ \& $M$ costs are the estimated costs of operating the CT and are estimates of system avoided energy costs.

The addition of a senerating resource to the PGE system in 1996 would provide sufficient reserves if adverse hydro conditions caused the existing PGE system to be nnable to meet projected loads. Under typical or average conditions, however, the resource would not normally be operated, but would be available in the event of the low water conditions. For this filing, the power cost estimates used to develop avoided energy costs include the expected operation of the energy (CT) resource, but only to the extent that it would be operated during periods when other less expensive resources are nnavailable.

The construction or acquisition of the resource is assumed to take up to four years to bring to operating capability. This is based on the expected construction time for a combustion turbine. 


\section{Capacity Retirements}

PGE has no planned retirements of existing plant capacity during the next fifteen years. For planning purposes, certain capacity purchase and exchange contracts with BPA and California utilities will be reduced from a current level of $650 \mathrm{~mW}$ to zero by 1992. 
Table 1

Portland General Electric Company Avoided Energy Costs

OAR 860-29-080(2)(a)

Decremental Energy Costs 1987-1992

YEAR

1987

1988

1989

1990

1991

1992

\section{Calendar Ovarter}

Third

Fourth

First

Second

Third

Fourth

First

Second

Third

Fourth

First

Second

Third

Fourth

First

Second

Third

Fourth

First

Second
Costs

(Cents/kWh)

1.3

1.9

2.0

1.3

1.6

2.3

2.2

1.4

1.8

2.3

\section{4}

1.5

1.8

2.5

2.4

1.6

1.9

2.5

2.5

Note: Costs are based on a $10 \mathrm{mWa}$ load decrement and are expressed in current year dollars. 
Table 2

\section{PORTLAND GENERAL ELECTRIC COMPANY \\ Plans for Capacity Additions \\ OAR 860-29-080(2)(b)(c)}

\begin{tabular}{|c|c|c|c|}
\hline & $\begin{array}{l}\text { Committed } \\
\text { Qualifying } \\
\text { Ereilities }\end{array}$ & $\begin{array}{l}\text { Capacity/ } \\
\text { Energy } \\
\text { Exchange }\end{array}$ & $\begin{array}{l}\text { Capacity/ } \\
\text { Energy } \\
\text { Resource }\end{array}$ \\
\hline In-Service Year & Various & 1990 & 1996 \\
\hline Size (MW)-PGE & 30 & 225 & 105 \\
\hline $\begin{array}{l}\text { In-Service Cost } \\
\text { (S millions) }\end{array}$ & $\mathbf{N} / \mathbf{A}$ & $\mathbf{N} / \mathbf{A}$ & 49.04 \\
\hline $\begin{array}{l}\text { In-Service Cost } \\
(\mathrm{S} / \mathrm{kW})\end{array}$ & $\mathbf{N} / \mathbf{A}$ & $\mathbf{N} / \mathbf{A}$ & 467.00 \\
\hline Life (Years) & $20-30$ & 20 & 20 \\
\hline $\begin{array}{l}\text { Fuel Costs } \\
\text { (Ist Year - } \\
\text { Cents/kWh) }\end{array}$ & $\mathbf{N} / \mathbf{A}$ & $\mathbf{N} / \mathbf{A}$ & 42 \\
\hline $\begin{array}{l}\text { OsM Costs } \\
\text { (1st Year - } \\
\text { Cents/kWh) }\end{array}$ & $\mathbf{N} / \mathbf{A}$ & $\mathbf{N} / \mathbf{A}$ & 0.33 \\
\hline $\begin{array}{l}\text { Purchase Price } \\
\text { (1st Year - } \\
\text { Cents/kWh) }\end{array}$ & $3.6-6.6$ & & \\
\hline
\end{tabular}

$$
E-23 / E-24
$$





\section{SECTION II \\ AVOIDED COST AND PUC INFORMATIONAL TABLES}

\section{Ayoided Cost and Purchase Rate}

The purchase rate for power produced by qualifying facilities is based on the Company's estimated avoided costs for power with the specific delivery characteristics of the qualifying facility. The avoided costs represent the economic value of the power delivered to PGE. The purpose of this section is to deseribe the important elements which are evaluated to determine the appropriate power purchase price for any particular qualifying facility. Section I system cost data is expanded and converted to year-by-year system avoided costs in Attachment 1PUC Informational Trbles and in Attachment 2 which sets out additional, summary, avoided cost information. These tables are based on the assumption that the power from a qualifying facility is a direct substitute for PGE system resources.

PGE's actual avoided costs applicable to a particular qualifying facility may differ significantly from the avoided costs applicable to other facilities and from costs set out in this document. These avoided cost differences and resulting price differences depend on variations in qualifying facility power supply characteristics. OAR 860-29-040(6) summarized below, deseribes many of the power supply differences which result in avoided cost differences and will affect resultant power purchase prices:

(1) The data provided pursuant to OAR 860-29-080(2) and the Commission's evaluation of the data:

(2) The availability of expacity or energy from a qualifying facility during PGE's system daily and seasonal peak periods, including:.

(a) The ability of the utility to dispatch output of the qualifying facility:

(b) The expected or demonstrated reliability of the qualifying facility:

(c) The terms of any contract or other legally enforceable obligation;

(d) The extent to which scheduled outages of the qualifying facility can be usefully coordinated with scheduled outages of the utility's facilities;

(e) The use of energy and/or capacity supplied from a qualifying facility during system emergencies, including its ability to separate its load from its generation;

(f) The Individual and agsregate value of energy and capacity from quallf ying facilities on the electric utility system; and

(B) The smaller capacity inctements and the shorter lead times available, if any, with sdditions of capecity from qualifying facilities.

The list of factors influencing purchase prices for power from QFs establishes the fundamental telationship between PGE avoidable costs and the price PGE can pay QF's for electric energy supplied to PGE.

The avoided cost/purchase price evaluation will separate power deliveries into firm 
and nonfirm categories. Firm power deliveries from QF's may allow PGE to defer or cancel power supply arrangements including new plant construction. The ability to schedule and dispatch the resource also affects the value of a QF to PGE. In order to be considered firm power, PGE requires assurances from the QF that the qualifying facility will meet its stated, firm delivery obligations over the life of the agreement. This is necessary to avoid undue burdens on utility customers as a result of nonperformance by a qualifying facility. The avoided costs for a firm power supply of sufficient length may include the costs of the 1996 avoidable resource. The avoided costs of firm deliveries may be further refined to accommodate specific power delivery characteristies of the qualifying facility which differ from the basic assumptions used in this filing to develop avoided cost/price tables.

Nonfirm power deliveries will senerally be those deliveries made by QF's on an "as available" basis. Avoided costs associated with QF nonfirm power deliveries will be based on variable operating costs the PGE system would incur to acquire nonfirm power as delivered by the QF. Non-firm avoided costs do not include costs associated with plant construetion and long-term power purchase contracts between utilities. Non-firm delivered power purchase prices cannot be contractually set significantly in advance of actual delivery of power. As power supply conditions change in the future, the non-firm. purchase prices may change, potentially ineluding time of delivery (day/night) differentials.

\section{RUC Informational Apoendices}

Attachment I to this filing contains tables which PGE has completed pursuant to the requirements of the Public Utility Commission. The tables provide estimated prices based on the avoided fixed (capital) costs of the future resource that is avoidable and system variable operating costs by year. Qualifying facilities must provide firm power to allow PGE to evoid the capital costs of the avoidable resource in order to qualify for purchase rates which include the fixed costs of the avoidable resource. The primary manner to qualify is by setting a firm power delivery schedule. Actual ourchase prices (determined at the time of delivery or contraetually) depend on the imoortant power suoply considerations previously deseribed and on OF ootions for levelization and purchase price arransements.

The Attachment 1 tables set ont prices calculated with and without levelization for QF firm power contracts of varying start dates and terms (in years). Appendices $A$ and $B$ provide optional levelized fixed costs for firm energy deliveries that would displace the 1996 resource. The levelized cost/price options are computed to begin with deliveries starting in 1992 or in the first year of the purchase contract, whichever is later. This cost levelization starts four years prior to the in-service date for the avoidable resource to eccommodate the lead time required to construct the avoidable resource. As \& result, levelization increases the effective $Q F$ contract purchase price above nonlevelized prices in the four years prior to 1996 , but decreases prices in the post-1996 period.

Appendix $C$ summarizes the avoided energy costs which reflect the svoided costs shown on Table I of Section I. This table is used with Appeadix A end/or B to derive an estimated purchase price for firm QF power deliveries. 
Appendices $D$ and $E$ are similar to Appendices $A$ and $B$, except the cost figures are applicable to QF contracts which do dot request levelized fixed costs prior to 1996. From 1996 through the remainder of a QF contract, the QF's estimated rate would consist of the fixed costs described in Appendix $D$ and $E$ and the avoided energy costs shown in Appeadix C.

\section{Additional Information}

Attachment 2, Table A provides the year-by-year fixed costs of the 1996 CT resource. These costs are first expressed in annual cents per kilowatt-hour in 1996 dollars. The costs are then escalated at the inflation rate to yield year-byyear annual fixed costs in nominal dollars. This teehnique allows for varying contract leagths and is reflected (on a levelized basis) in the Attachment i, Appendix $A$ and $C$.

Table B of Attachment 2 is a summary of the year by year avoided costs of a firm power delivery for the tweaty year period, 1987 through 2006. 


\section{PORTLAND GERERAL ELEETRIC COMPANY}

Levelized fixed cost Capacity payments

(s/nu-Mo.)

\begin{tabular}{|c|c|c|c|c|c|c|c|c|c|c|}
\hline \multirow{2}{*}{$\begin{array}{l}\text { VEARS III } \\
\text { Courtuet }\end{array}$} & \multirow[b]{2}{*}{1987} & \multicolumn{9}{|c|}{ IEAR IV YHICY PELIVERIFS SEGIY } \\
\hline & & 1938 & 1989 & 1990 & 1991 & 19092 & 1093 & 1906 & 1995 & 1996 \\
\hline 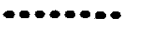 & 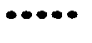 & $\cdots$ & $\cdots$ & $\cdots$ & $\cdots$ & $\cdots$ & $\cdots$ & $\cdots$ & $\cdots$ & $\cdots$ \\
\hline $\mathbf{5}$ & 0.00 & 0.00 & 0.00 & $0 . \infty 0$ & 0.00 & 0.17 & 0.36 & 0.59 & 0.85 & 1.16 \\
\hline 10 & 0.17 & 0.29 & 0.38 & 0.45 & 0.50 & 0.55 & 0.69 & 0.86 & 1.06 & 1.25 \\
\hline 15 & 0.55 & 0.59 & 0.63 & 0.67 & 0.70 & 0.72 & 0.85 & 1.00 & 1.16 & 1.36 \\
\hline 20 & 0.72 & 0.75 & 0.7 & 0.70 & 0.82 & 0.84 & $0 . \%$ & 1.10 & 1.25 & 1.43 \\
\hline 25 & 0.84 & 0.85 & 0.87 & 0.89 & 0.90 & 0.92 & 1.06 & 1.18 & 1.53 & 1.50 \\
\hline 30 & 0.92 & 0.93 & 0.96 & 0.96 & 0.97 & 0.98 & 1.90 & 1.26 & 1.60 & 1.57 \\
\hline 35 & 0.98 & 0.99 & 1.00 & 1.08 & 1.02 & 1.13 & 1.16 & 1.29 & 1.45 & 1.62 \\
\hline
\end{tabular}




\section{PORTLAND FENERAL FLECTRIC COMPANY}

\begin{tabular}{|c|c|c|c|c|c|c|c|c|c|c|}
\hline \multirow{3}{*}{$\begin{array}{l}\text { WhIBER } \\
\text { VECAS II } \\
\text { cowruct }\end{array}$} & \multicolumn{10}{|c|}{$\begin{array}{l}\text { Levelized Fixed Cost Eneroy Payments } \\
\text { (Centa/nuil) }\end{array}$} \\
\hline & & & & EAR II & AICA DE & IVERIFF & EETM & & & \\
\hline & 1967 & 1968 & 1909 & 1990 & 1991 & 1992 & 1993 & 1904 & 1995 & 1996 \\
\hline a.. & $\ldots$ & ..... & ..... & $\cdots$ & $\ldots$ & $\cdots$ & $\cdots \cdots$ & $\cdots \cdots$ & $\cdots$ & $\cdots \cdot$ \\
\hline 5 & 0.00 & 0.00 & $0 . \infty 0$ & $0 . \infty 0$ & 0.00 & 0.12 & 0.25 & 0.60 & 0.58 & 0.78 \\
\hline 10 & 0.12 & 0.20 & 0.26 & 0.31 & 0.35 & 0.38 & 0.68 & 0.59 & 0.71 & 0.86 \\
\hline 13 & 0.38 & 0.41 & 0.43 & 0.46 & 0.48 & 0.50 & 0.39 & 0.69 & 0.80 & 0.92 \\
\hline 20 & 0.50 & 0.51 & 0.53 & 0.55 & 0.56 & 0.57 & 0.66 & 0.76 & 0.86 & 0.90 \\
\hline 25 & 0.57 & 0.59 & 0.60 & 0.61 & 0.62 & 0.63 & 0.72 & 0.81 & 0.92 & 1.03 \\
\hline 30 & 0.63 & 0.64 & 0.65 & 0.66 & 0.67 & 0.67 & 0.76 & 0.85 & 0.96 & 1.00 \\
\hline 35 & 0.67 & 0.68 & 0.69 & 0.70 & 0.70 & 0.71 & 0.70 & 0.89 & 0.99 & 1.11 \\
\hline
\end{tabular}

Prices shoun cbow becese effective and a part of the purchase price no earlfer then 1992 for purchases inleh bugin on or before 1992. 5/27/87 
ATtACAWENT I

APpENDIX 6

\section{contlano general gletere company}

APpEIDIX 6

Estinated Varicble Energy Prices (Cents/anis)

$19 A 8$
1967
1908
1909
1990
1991
1992
1993
1996
1995
1996
1997
1996
1999
2000
2001
2002
2003
2004
2005
2006

Bing finery

vinter giwer amul

$1.9 \quad 1.3 \quad 1.6$

$2.1 \quad 1.5,9.8$

$2.3 \quad 1.6 \quad 1.9$

$2.6 \quad 1.7 \quad 2.1$

$2.5 \quad 1.7 \quad 2.1$

$\begin{array}{lll}2.5 & 1.8 & 2.2\end{array}$

$2.7 \quad 1.9 \quad 2.3$

$2.8 \quad 2.0 \quad 2.4$

$3.0 \quad 2.2 \quad 2.6$

$\begin{array}{lll}3.2 & 2.3 & 2.8\end{array}$

$\begin{array}{lll}3.3 & 2.5 & 2.9\end{array}$

$\begin{array}{lll}3.9 & 2.7 & 3.3\end{array}$

$\begin{array}{lll}6.2 & 2.9 & 3.6\end{array}$

4.43 .13 .7

6.63 .3 " 4.0

$6.8 \quad 3.6 \quad 4.2$

$5.1 \quad 3.7 \quad 4.4$

$5.84 .0 \quad 4.9$

$6.14 .2 \quad 5.2$

$6.34 .5 \quad 5.6$

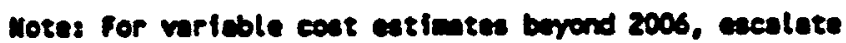
6.63 par yar. 
ATtacunient 1 .

APPENDIX O

\section{gontLAVD GENFRAL ELFETRIE COMPANY}

APPENOIX D

Monlevelized flxed cost cepecity prices

s/ru-Month

Year of cempletion of moldable enerating feclltey by utllty: 1996

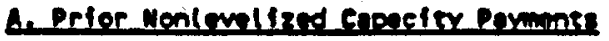

rear

Parment No cepecity Poyments

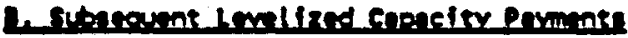

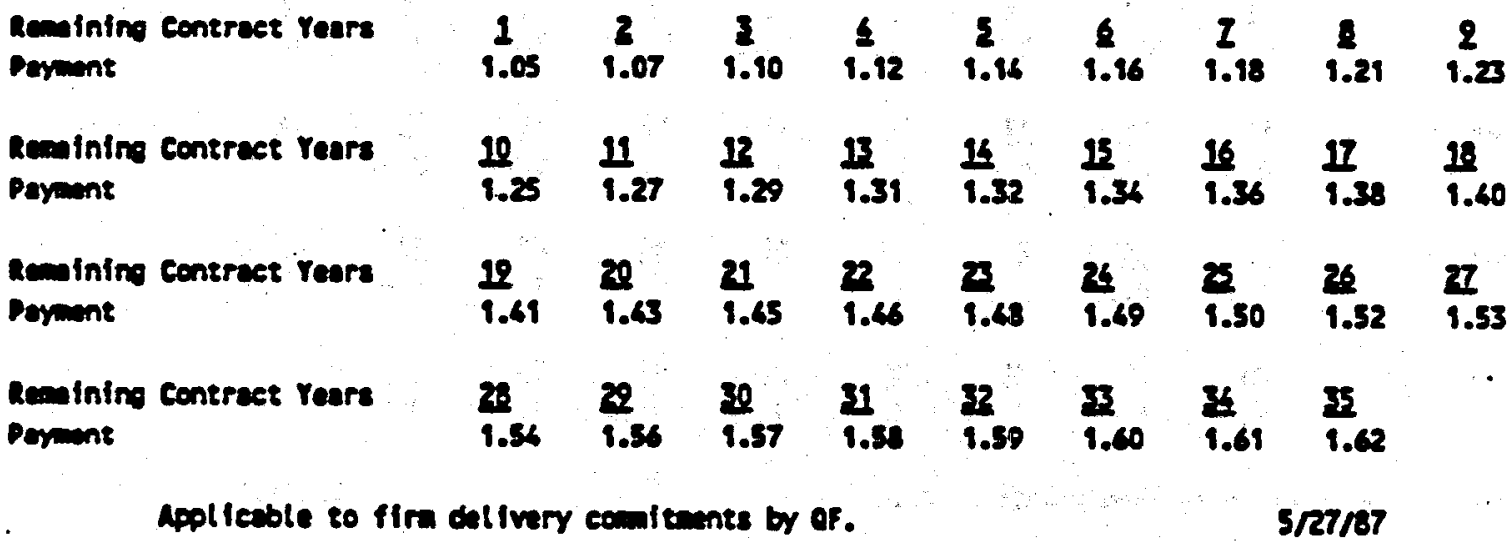




\section{CORTLANO GEMERAL FLETRIC COMPANY}

APpenotx E

Monlevilized fixed cost Enaroy Prices

Cenes/ $\mathrm{rm}$

Year of completion of ovoldable emerating factity by utitity 1996

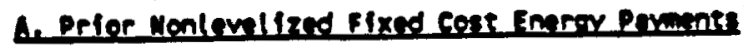

Your

Poyment Mo Fixed cest Encrey Payments 1987-19\%5

\section{T. Eubereunt tevellied fixed Cost Emero povmints}

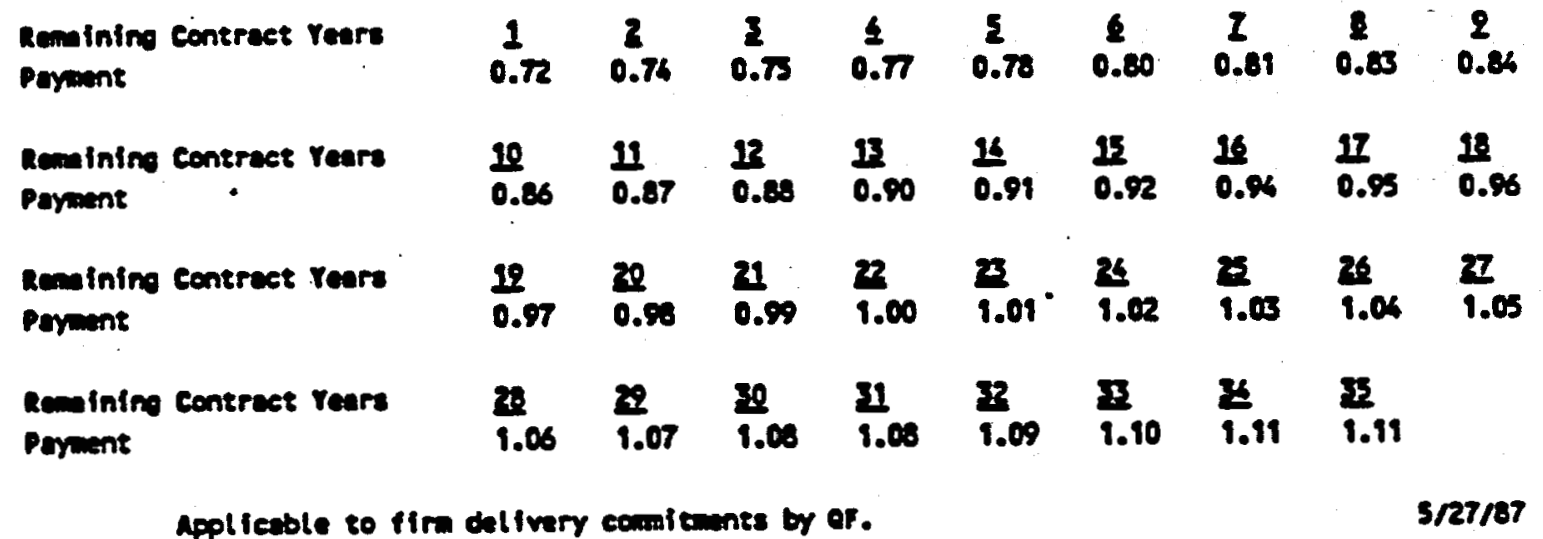


ATtAChMENT 1 APPENDIX F

\section{CORTLAP GEMERAL FLETRIC COAPAMT}

APPENDIX F

(Deseription of Ueflity's mexe canating Focility)

une and Lecation: Eneroy Resource, PEE Eervite Aree

Troe of Mants centustion Turbine

Plemed Completion Date: 1996

Torel eapector (nus) 105

Utilty's thare (m): 105

Estineted rotal plent costs $449,040,000$

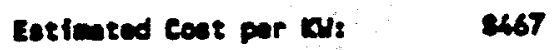

Firat rear estiened fual cost (cents/knh): 4.2

Firse rear Estiunted other varicble osn cost (Cents/nth): 0.33

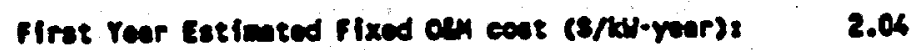




\section{Portland General Electric Company}

Estimated Fixed Costs of the 1996 Energy Resource" Cents/kWh

Year

1996

1997

1998

1999

2000

2001

2002

2003

2004

2005

2006

2007

2008

2009

2010

2011

2012

2013

2014

2015
Annualcoss

0.91

0.96

1.00

1.04

1.09

1.14

1.19

1.25

1.30

1.36

1.42

1.49

1.56

1.63

1.70

1.78

1.86

1.94

2.03

2.12

-Estimated fixed costs of a combustion turbine.

Annual costs constant in real dollars and escalating at an infiation rate of $4.53 \%$ per year. 
Attachment 2

Table B

Portland General Electric Company

Summary - Estimated Year by Year Avoided Costs"

1987 - 2006

Components of Avoided Costs (Cents/kWh)

\begin{tabular}{lrrr} 
& & & \\
Year & Variable & Fixed & $\begin{array}{c}X \\
\text { Toral }\end{array}$ \\
\cline { 4 - 4 } 1987 & & & \\
1988 & 1.60 & & 1.60 \\
1989 & 1.81 & & 1.81 \\
1990 & 1.93 & & 1.93 \\
1991 & 2.05 & & 2.05 \\
1992 & 2.11 & & 2.11 \\
1993 & 2.19 & & 2.19 \\
1994 & 2.33 & & 2.33 \\
1995 & 2.40 & & 2.40 \\
1996 & 2.60 & & 2.60 \\
1997 & 2.75 & & 3.66 \\
1998 & 2.89 & .91 & 3.85 \\
1999 & 3.31 & .96 & 4.31 \\
2000 & 3.55 & 1.00 & 4.59 \\
2001 & 3.73 & 1.04 & 4.82 \\
2002 & 3.95 & 1.09 & 5.09 \\
2003 & 4.23 & 1.14 & 5.42 \\
2004 & 4.40 & 1.19 & 5.65 \\
2005 & 4.91 & 1.25 & 6.21 \\
2006 & 5.16 & 1.30 & 6.52 \\
& 5.39 & 1.36 & 6.81
\end{tabular}

- Assuming firm power deliveries equivaleas to PGE operation and dispateh of the resources. 


\section{、}


PACIFIC POWER \& LIGHT COMPANY

020 S.W.SITH AVENUE · PORTLAND. OREGON $97204 \cdot(5031243 \cdot 122$

Fredric D. Reed

Senior Vice President

May 29, 1987

Dr. Barbara J. Combs, Aduinistrator

Economic Research Division

Public Ut1lity Commission of Oregon

300 Labor \& Industrles Bullding

Salem, OR 97310

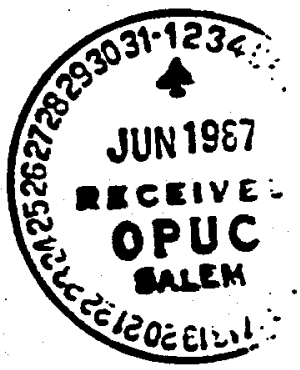

Dear Dr. Combs:

Pacific Power 6 Light Company hereby wihdraws Schedule 5 tariff which was submitted Kay 30, 1986, and hereby subults revised PURPA Section 210 avolded cost Information:

\section{OAR $860-29-040$ (5)}

Standard rates for purchases from qualifylng facllitles with a generating design capacity of $100 \mathrm{kw}$ or 1 ess are set forth in revised Schedule 5. Pacific hereby submite an original and four coples bearing an effective date of JuIy 1, 1987.

\section{OAR 860-29-080 (3) (a)}

Nonfirm Energy: The prices for purchases of nonfirm energy, expressed in cents per kWh on a censonally differentlated basis, and on an average basis, for the calendar year 1987 and next nine years, are set forth in Exhibit 1 , Appendix C.

Firm Energy: The prices for purchases of firm energy. expressed in cents per kWh on a seasonally differentiated basis, and on an average basis, for calendar gear 1987 and next nine yeare, are set forth in Exh1b1t 1 , Append1x C.

\section{OAR 860-29-080 (3) (b)}

Paclfic currently plans on meeting its future load requirements with purchases under the Power Sales Contract with BPA. The planned purchases will be of a quantity necessary to bring Paciflc into losd and resource balance.

Paclfic does not presently plan to retire any existing generating plant during the succeding 15 gears. 


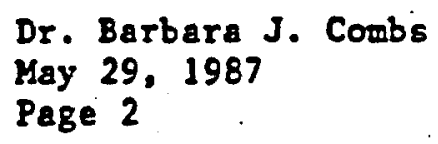

OAR 860-29-080 (3) (c)

Pacific's anticipated costs of future purchases under the Power Sales Contract are listed in Exhibit 1, Appendix F.

OAR 860-29-090

Pacific's prices for purchases from qualifying facilities are set forth in Exhibit 1.

Pacific intends to have this filing supersede all previously filed avoided costs, and Pacific will use these avoided costs beginning July 1, 1987.

If you have any questions regarding this filing, please contact Jerry Rust (503) $243-4942$.

Very truly yours,

Fredric Deed

FDR/JR:tjC

jdrcombx.Itr

$E-38$ 
PACIFIC POWER \& IIGHT COMPANY

SCHEDUTE 5

PARTIAL REQUIREMENTS SERVICE

$100 \mathrm{KW}$ OR IESS

AVAILABLE:

In all territory served by Company in Oregon.

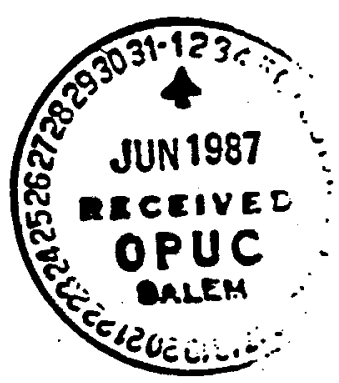

APPLICABLE: 1ess.

To qualifying facilities with a generating design capacity of $100 \mathrm{kw}$ or

MONTHLY BILLING:

The wonthly billing to the qualifying facility shall be the sum of the Basic Charge specified hereunder and the monthly billing for takings frow Company, in accordance with the applicable schedule or schedules for the type of service received.

Basic Charge: $\$ 5.00$

GENERATION CREDIT:

Company, in accordance with the terms of a contract between the qualifying facllity and Company, shall pay, for all separately metered kllowatt-hours of qualifying facility generation, 1.88 cents per kllowat-hour for the period November through Apr 11 , and 1.65 cents per kilowatt-hour for the pertod May through October.

\section{PARALIEL OPERATION:}

Interconnection of a qualifying facility with Company's system will be permitted only under the terms of contract between the qualifying facility and Company. Such contract shall include but not be limited to the following:

(1) The qualifying facility shall Indemify and hold harmless the Company from any and all liability erising from the operation and interconnection of qualifying facility.

(2) Qualifying facility shall provide a lockable disconnect switch to lsolate qualifylng facllity's generation from Company's system. Such switch shall be accessible to Company and Company shall have the right to lock such disconnect switch open whenever necessary to meintain cafe electrical operating conditions, or whenever the qualifying facility adversely affects Company's system.

(3) Qualifying facility shall provide an additional peter base adjacent to the delivery weter to measure the qualifying facllity's total generation independently froo the qualifying faclilty's load. For three-phase generation the qualifying facility will also provide a meter base for a kvar meter.

(Continued)

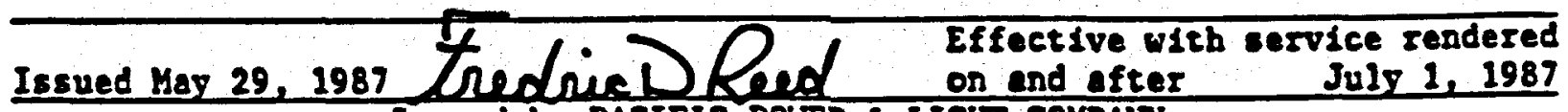
Issued by PACIFIC POWER \& IIGHT COMPANY

Fredric D. Reed, Senior Vice President

TF1 5-1P Public Service Building, Portland, Oregon

$$
E-39 / E-40
$$




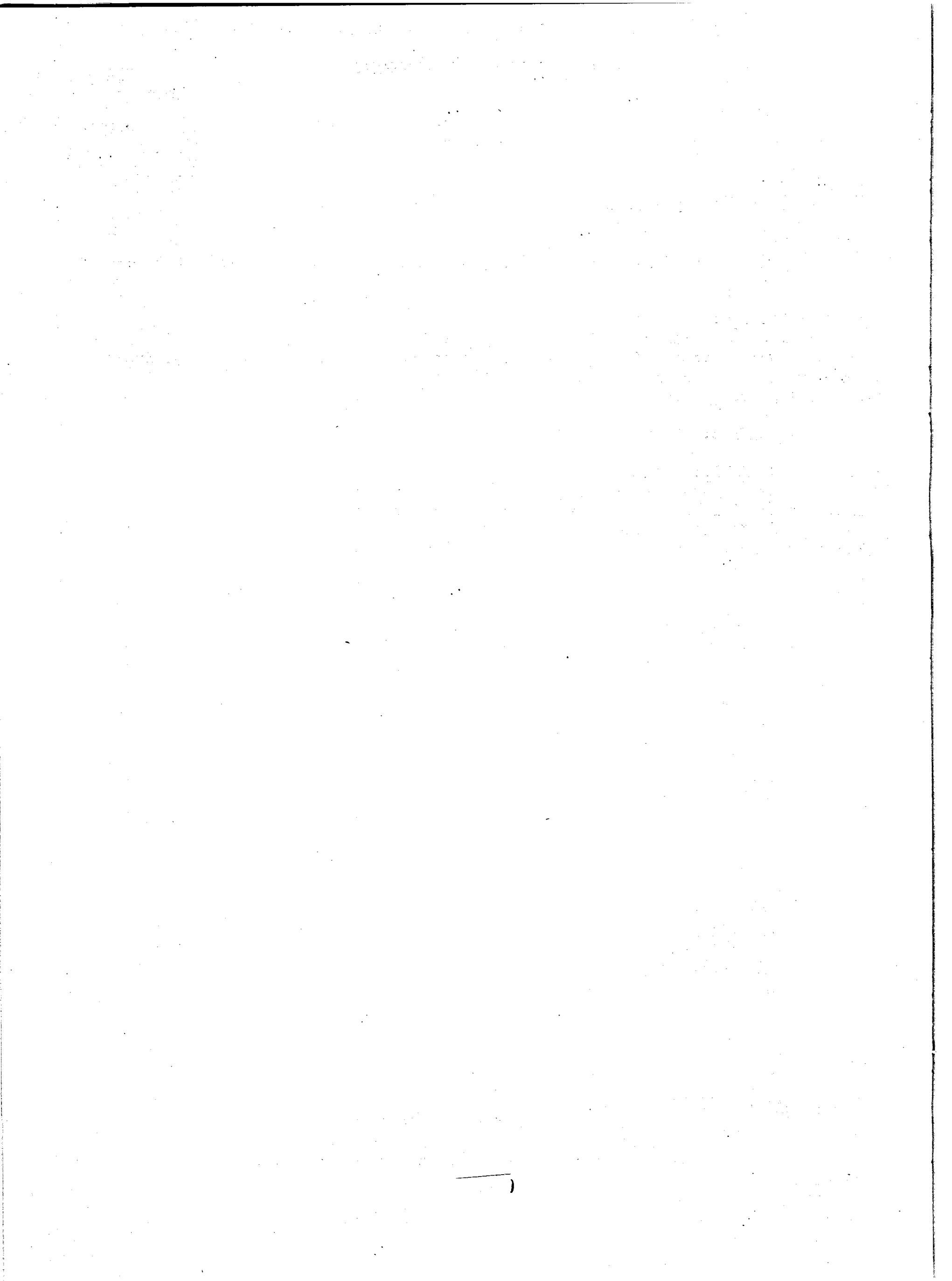


EXHIEIT 1

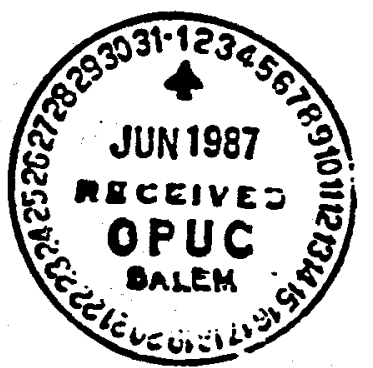

PACIFIC POWER \& LIGHT COMPANY

AVOIDED COST PRICES FOR PURCHASE POWER

EFFECTIVE

JULY 1, 1987 


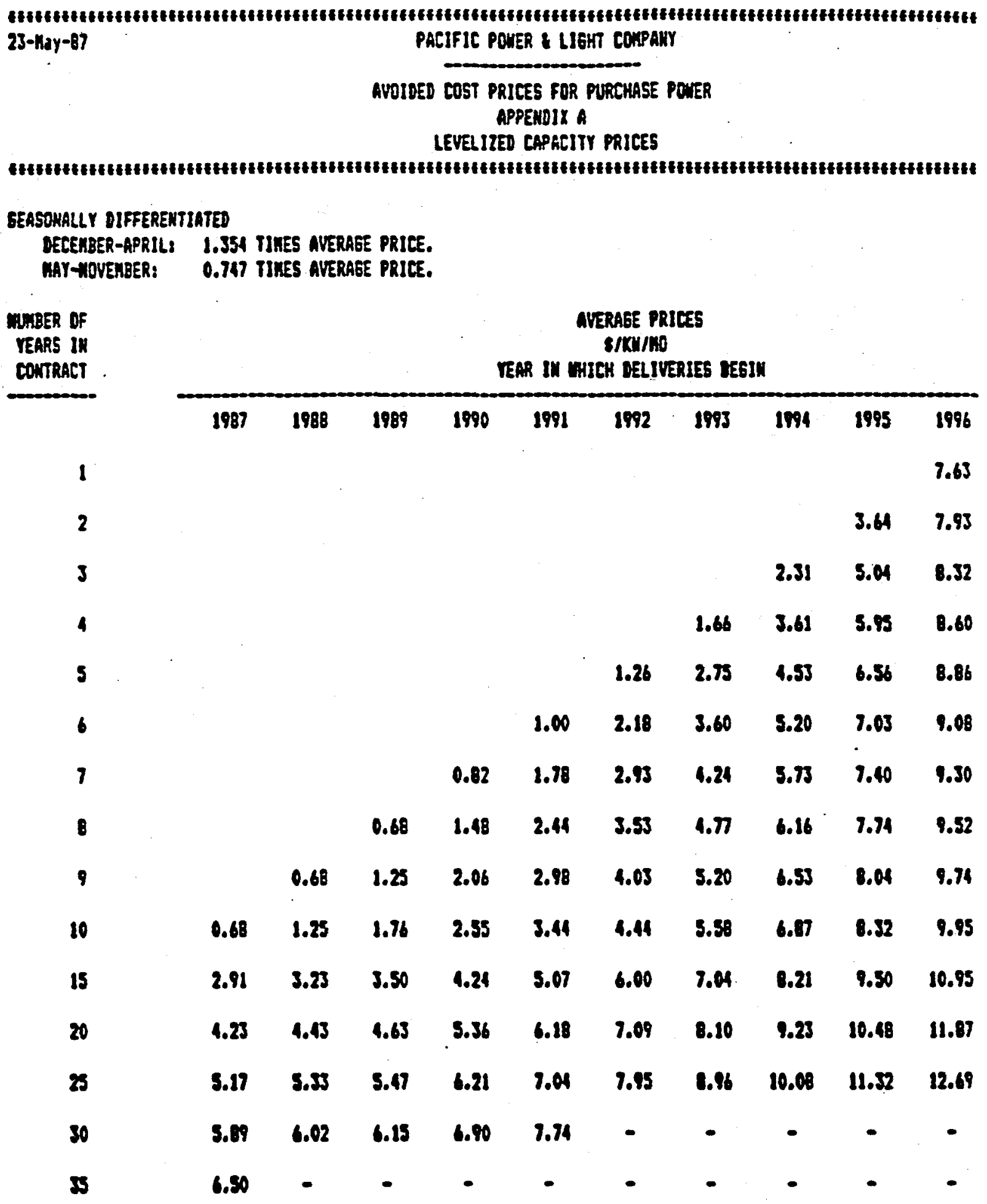

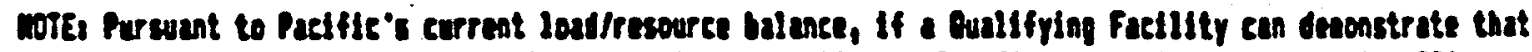

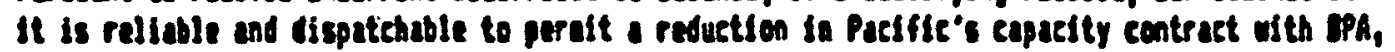
chere will of en additional capeity pupent to be detroined in the cource of contrat aegotiatiens.

The avoided cost prices ay be adjusted to reflect lasses anen 4plicable.

Prices show above becose effeetive and o purt of the purchase price in 1989. Wo levelized prices avilable miar to 1989. 


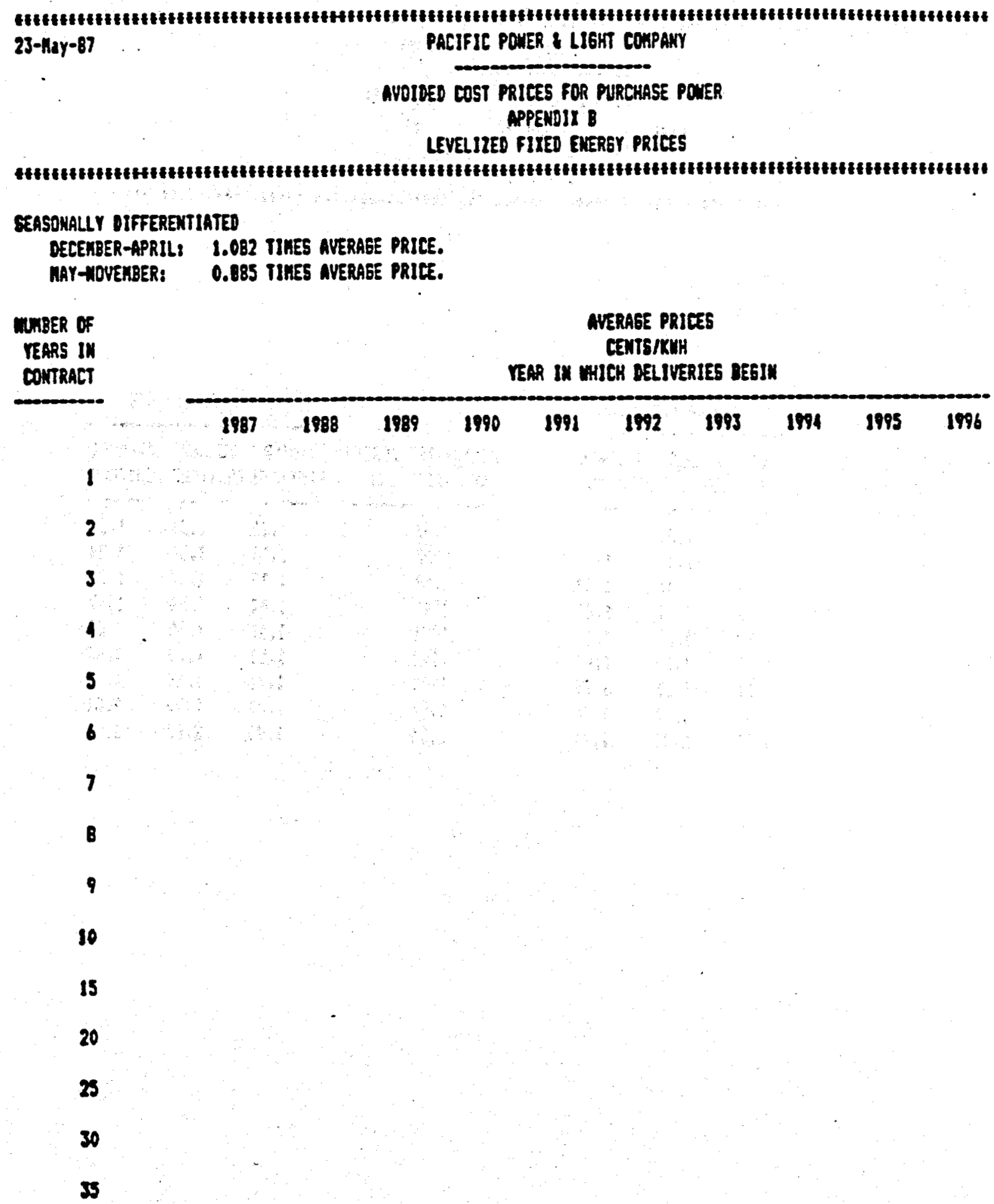




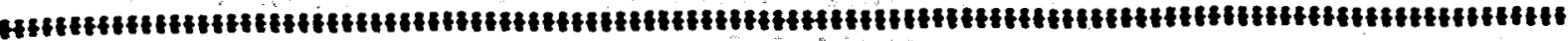

$23-112 y-87$

PAEIFIC POIER \& UIERT COKPANYY

AWIDED COST PRICES FaR PLRQUASE POLER

APPENDIX $\mathrm{C}$

VARIABLE EMERGY PRICES

IENTSRKH

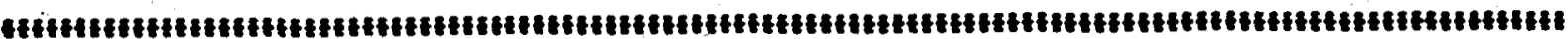

EEASOMaLLY DJFFEREMTIATED

SUMnER WOKTHS ARE HAY - OCTOBER

vinTER WDHTHS MOE NOVEKBER - MPRIL

MON-FIRI EMERGY PRICES

DELIVERIES QURINE MUMTER SWMER AVERAGE COUTRACT YEAR CENT/KMH CEMTIKUH CEMIKMH

\begin{tabular}{|c|c|c|c|}
\hline 1987 & 1.21 & 1.26 & 1.23 \\
\hline 1988 & 1.21 & 1.34 & 1.28 \\
\hline 1989 & 1.35 & 1.43 & 1.38 \\
\hline 1990 & 1.42 & 1.54 & 1.47 \\
\hline 1991 & 1.51 & 1.68 & 1.55 \\
\hline 1992 & 1.59 & 1.70 & 1.63 \\
\hline 1993 & 1.71 & 1.82 & 1.75 \\
\hline 1994 & 1.80 & 1.90 & 1.84 \\
\hline 1995 & 1.90 & 2.02 & 8.84 \\
\hline
\end{tabular}

FIEN ExeAt PRICES

\begin{tabular}{|c|c|c|c|}
\hline $\begin{array}{l}\text { OELIVERIES MaRIVL } \\
\text { CONTRACT YEAR }\end{array}$ & $\begin{array}{l}\text { nImTER } \\
\text { CENT/KUH }\end{array}$ & $\begin{array}{l}\text { EHinEA } \\
\text { CENTKKHY }\end{array}$ & $\begin{array}{l}\text { AVERAGE } \\
\text { CENT/KUH }\end{array}$ \\
\hline 1987 & 1.21 & 1.26 & 1.23 \\
\hline 1988 & 1.24 & 1.34 & 1.28 \\
\hline 1989 & 1.35 & 1.43 & 1.38 \\
\hline 1990 & 1.42 & 1.51 & 1.47 \\
\hline 2991 & 1.51 & 1.68 & 1.55 \\
\hline 1992 & 1.59 & 1.70 & 1.63 \\
\hline 1993 & 1.71 & 1.82 & 1.75 \\
\hline 1894 & 1.80 & 1.90 & 1.84 \\
\hline 1995 & 1.50 & 2.02 & 1.94 \\
\hline
\end{tabular}




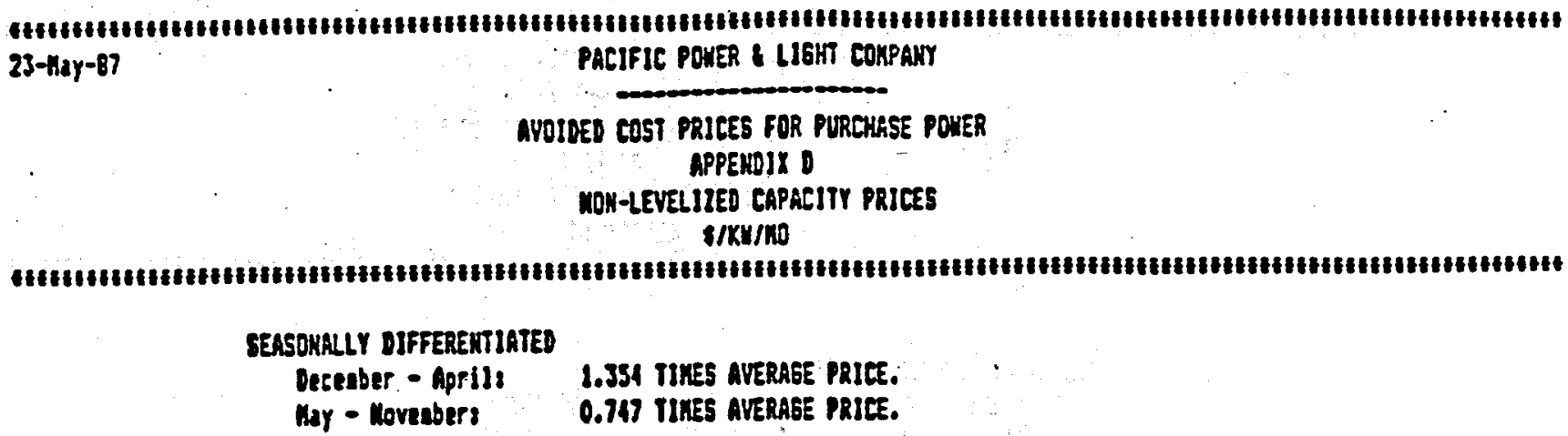

A. MRIOR MOY-LEVELIIED CAPACITY PAYKENTS

VEAR:

$1987 \quad 1988 \quad 1989$

AYERAGE PAYKEMTS:

- no capacitr parnents -

8. WUBSEQUER LEVELIED CAPACITY PAMEMTS

REMIMIMG CONTRAET VEARS:

$$
\begin{aligned}
& \frac{1}{7.63} \quad \frac{2}{7.93} \quad \frac{3}{8.32} \quad \frac{1}{8.60} \quad \frac{5}{8.86} \quad \frac{6}{9.08} \quad \frac{1}{9.30} \quad \frac{8}{9.52}
\end{aligned}
$$

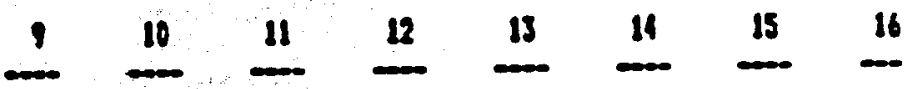

$$
\begin{aligned}
& \begin{array}{llllllll}
9.74 & 9.95 & 10.16 & 10.36 & 10.56 & 10.76 & 10.95 & 11.11
\end{array} \\
& \begin{array}{llllllll}
17 & 18 & 19 & 20 & 21 & 22 & 23 & 21
\end{array} \\
& \begin{array}{llllllll}
11.33 & 11.51 & 11.69 & 11.07 & 12.01 & 12.21 & 12.37 & 12.54
\end{array} \\
& 25 \quad 26 \\
& 12.69 \quad 12.05
\end{aligned}
$$$$
\text { a MeRAGE PAMKEMTS: }
$$$$
\text { PERAIMUMG CONTRACT YEARS: }
$$$$
\text { AYERABE PAYEIEIS: }
$$$$
\text { MEEAIUIKG CONTRACT YEARS: }
$$$$
\text { AVERAGE PAMEEMTSs }
$$$$
\text { cenaIMEms contract years: }
$$$$
\text { GVERAGE PAMEETIS: }
$$

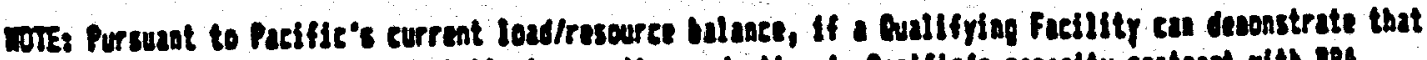

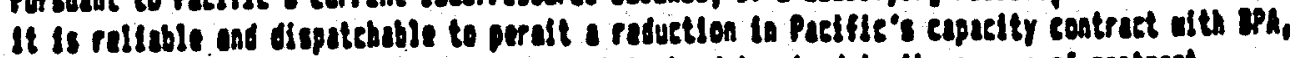
there will be an adoltional capaeity payeent to be ieturalaed to the course of contrast arpotiations. 


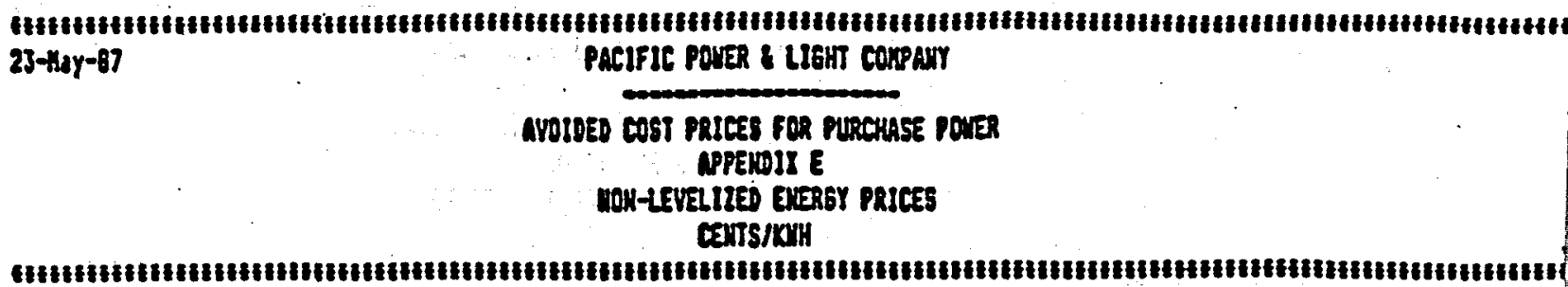

SERSONRLLY DIFFEREMTIATED

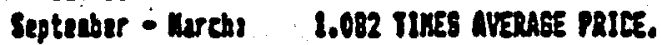

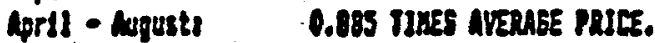

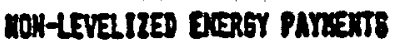

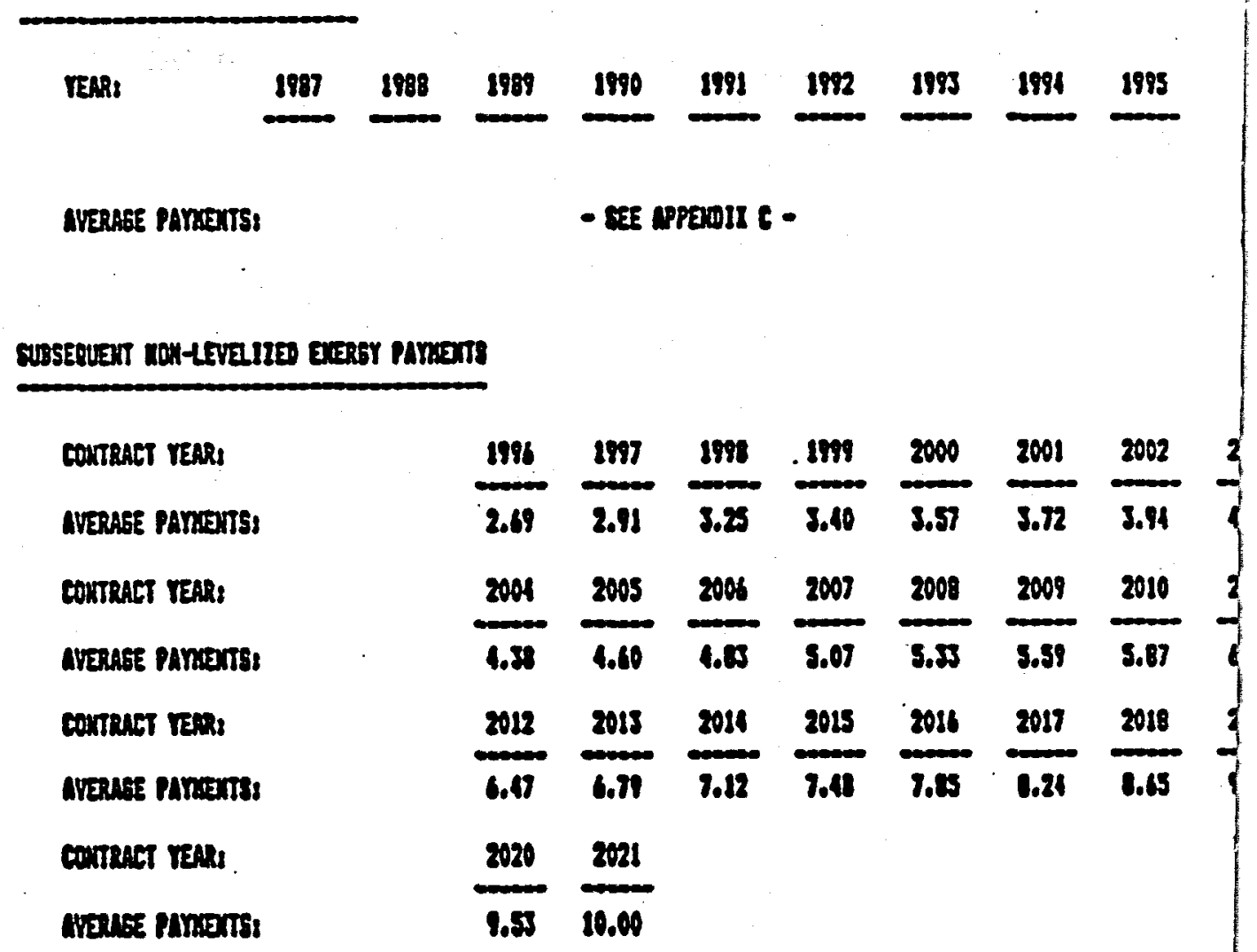




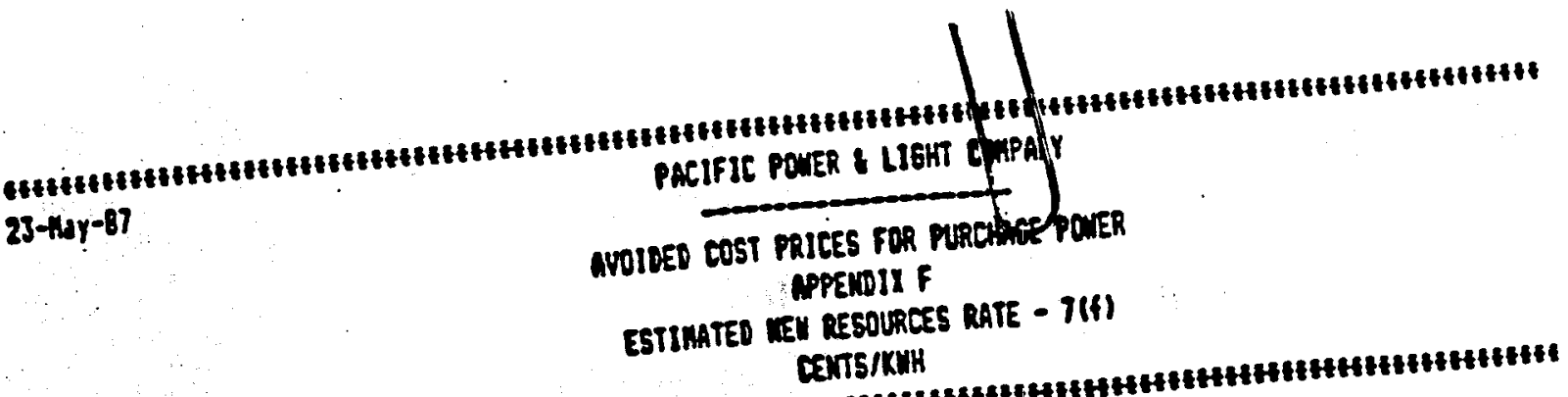

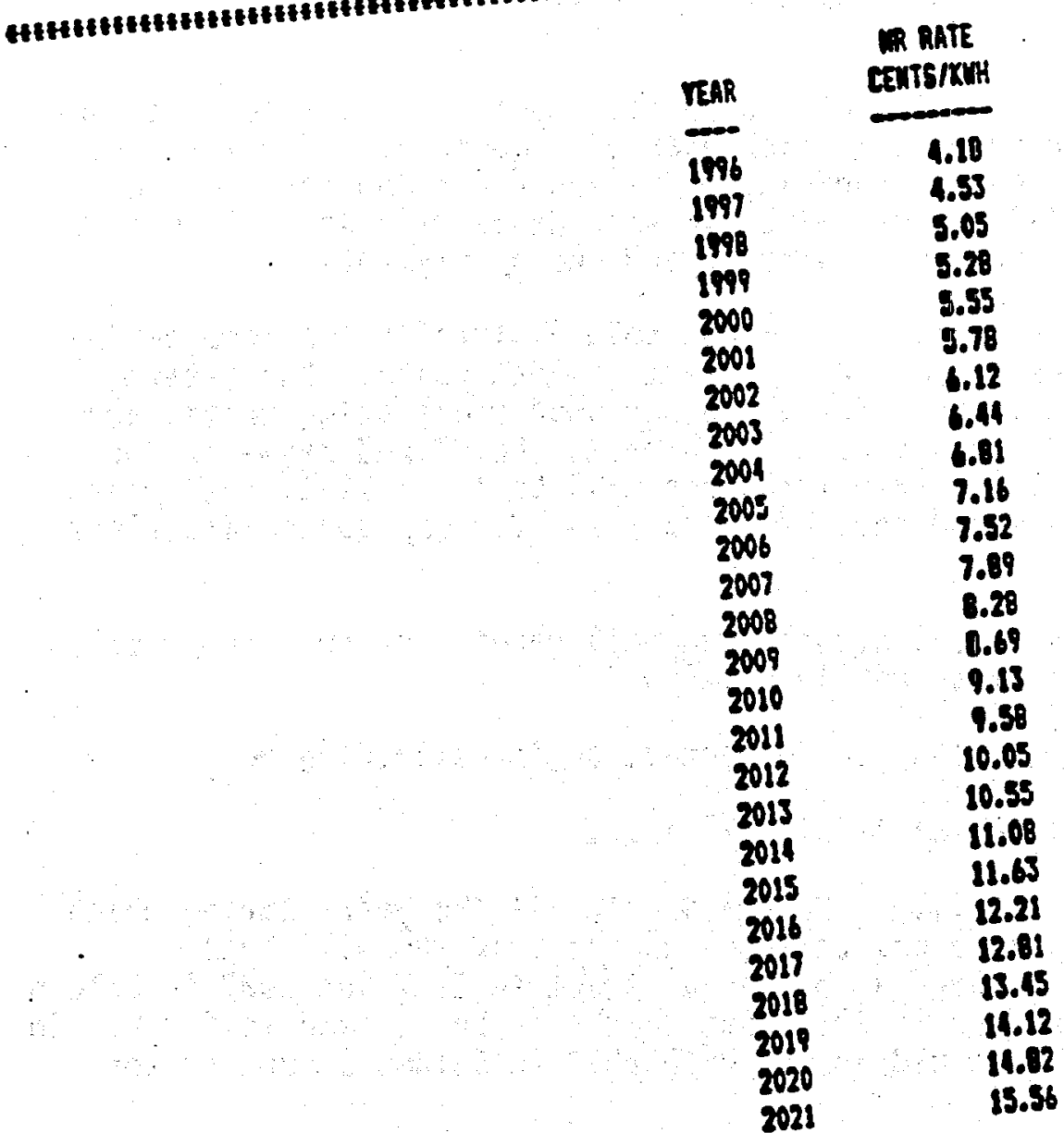

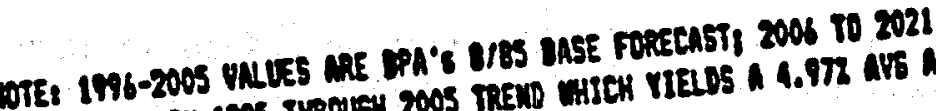

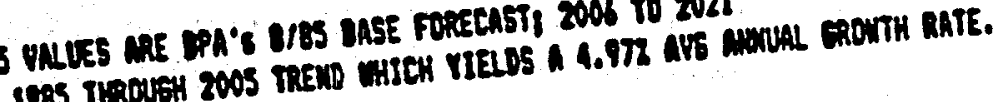


The attached worksheet can be used to compute an estimate of the per kwh payments you can receive in each year of a contract under which you sell power (firm energy and capacity) to Idaho Power Company. Actual contract payments will be determined in accordance with Appendices $A, B$, $C$ and $D$, and may include both capacity and energy payments.

The payments you receive for power sold will reflect a combination of the utility's short-term and long-term avoided costs. Short-term avoided cost payments, which reflect power supply operating costs, are paid throughout the lifetime of the contract. Levelized payments for long-term avoided costs of new resources will begin in 1998, four years in advance of the expected need of Idaho Power for new generating plant capacity.

To estimate the annual amounts you will receive under a power sales contract, follow the steps outlined below.

1. Decide on the year that you expect to begin delivering power.

2. Decide how long the contract will last.

3. On the worksheet, fill in Column B with all the years during which the contract will be effective. Example: if you will begin delivering power under a 35-year contract in 1987 put 1987 in Column $B$ next to the number 1, 1988 next to the number 2 , and so forth. In this example, you would end up with 2021 in Column B next to the number 35 .

4. If you plan on less than 35-year contract, cross out the remaining rows in every column.

5. If your contract will begin in or before 1998, find the levelized capacity from Appendix A which corresponds to the number of contract years remaining after 1997 . Enter that number in all rows of Column $C$ on the worksheet starting in 1998. Enter zero in all rows of Column C for contract years prior to 1998.

6. Calculate the cents per kwh avallable from the capacity payment by multiplying the numbers in Column $C$ by .1826 . Put these results in each row of Column $D$. As in Column $C$, all of the numbers in Column D should be zero prior to 1998 and a levelized amount for 1998 and all subsequent years of the contract.

7. In a manner simflar to your procedure in Step 5, find the levelized seasonal fixed energy payments from Appendix $B$ that correspond to 
the year you plan to begin deliveries and the length of contract you desire. Multiply each seasonal energy rate by the expected generation in that season to estimate seasonal fixed energy payments. Then add together the three seasonal payments and divide the total by the expected annual generation from the project. Put that number under Column $E$ of the worksheet for all years of your contract beginning with the year 1998. As in Step 6, all of the numbers in Column E should be zero for years prior to 1998.

8. The variable energy payments for your contract can be obtained from Appendix C. Annual variable energy prices should be calculated for your project from the seasonal rates using the procedure described in Step 7. To obtain variable energy payments for contract years not given directly by Appendix C, multiply each year's payment by 1.055 to obtain an estimate for the following year's payments. place variable energy payments for each year of the contract in Column F.

If your contract will start in 1998 or earlier, the variable energy payments for all years through 1997 are given on page 1, section (a). Your payments for 1998 are given on page 1, section (b) under the heading corresponding to the number of years remaining in your contract after 1997. Subsequent year's payments may be estimated by escalating the 1998 payment at a rate of 5.5 percent per year.

9. Add Columns D, E, and F. The result is an estimate of the price you could be paid in each year of your contract.

If you do several of these computations, you will notice that you ga in a price advantage both when you increase the length of a contract and when you delay a contract's beginning date to a later time (when power surpluses may be smailier).

$$
E-49 / E-5^{\circ}
$$





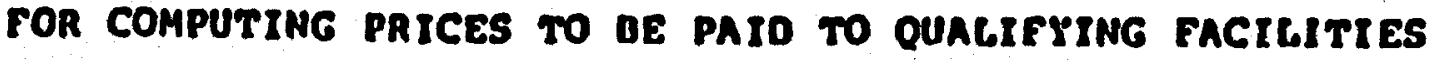

\begin{tabular}{|c|c|c|c|c|c|c|}
\hline A & B & C & D & $E$ & $F$ & 6 \\
\hline $\begin{array}{l}\text { TEAR IN } \\
\text { CONTRACT }\end{array}$ & $\underset{\text { YEAR }}{\text { CALENAR }}$ & $\begin{array}{c}\text { CAPACITY } \\
\text { PRICE } \\
\text { (\$/KW-MONTH) }\end{array}$ & $\begin{array}{l}\text { CONVERTED } \\
\text { CAPACITY } \\
\text { PRICF } \\
\text { (CENTS/KWH) }\end{array}$ & $\begin{array}{c}\text { FIXED } \\
\text { ENERGY } \\
\text { PRICE } \\
\text { (CENTS/KWH) } \\
\end{array}$ & $\begin{array}{l}\text { VARTABLE } \\
\text { ENERGY } \\
\text { PRICE } \\
\text { (CENTS/KWH) }\end{array}$ & $\begin{array}{c}\text { TOTAG } \\
\text { PRICE } \\
\text { (CENTS/KHH) } \\
D+E+F \\
\end{array}$ \\
\hline$\frac{1}{i 2}$ & & & & & & \\
\hline 3 & & & & & & \\
\hline 14 & & & & & & \\
\hline 3 & & & & & & \\
\hline 6 & & & & & & \\
\hline$\frac{7}{8}$ & & & 1 & & & \\
\hline 9 & & & & & & \\
\hline 10 & & & & & & \\
\hline$\frac{11}{12}$ & & & & & & \\
\hline$\frac{12}{13}$ & & & & & & \\
\hline 14 & & & & & & \\
\hline 15 & & & & & & \\
\hline 16 & & & & & & \\
\hline 17 & & & & & & \\
\hline 28 & & & & & & \\
\hline 19 & & & & & & \\
\hline 20 & & & & & & \\
\hline$\frac{21}{22}$ & & & & & & \\
\hline 23 & & & & & & \\
\hline 24 & & & & & & \\
\hline 25 & & & & & & \\
\hline 26 & & & & & & \\
\hline 27. & & & & & & \\
\hline 28 & & & & & & \\
\hline 29 & & & & & & \\
\hline$\frac{J u}{31}$ & & & & & & \\
\hline 32 & & & & & & \\
\hline 33 & & & & & & \\
\hline 34 & & & & & & \\
\hline 35 & & & & & & \\
\hline
\end{tabular}




\section{APpenoIX A}

LEVELIZED CAPAGITY PAMENTS

(\$MW-AONm)

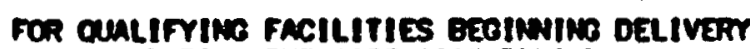

$$
\text { DURING. THE 1987-1990 PERICD }
$$

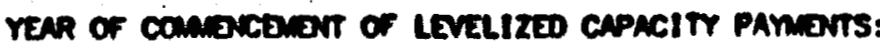

1990

A. PRIOR CAPACIT PAMUNTS

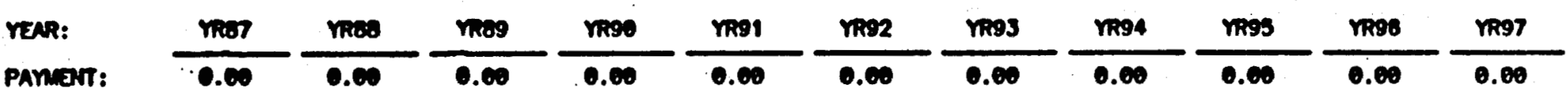

b. suesecurant capcity pamants

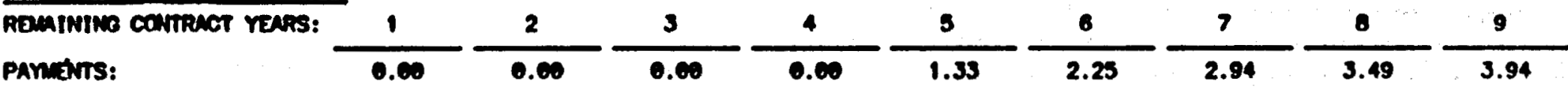

ROMININO Conthect reass:

panavis:

$\frac{10}{4.32} \frac{11}{4.65} \frac{12}{4.94} \frac{13}{5.21} \frac{14}{3.44} \frac{15}{5.66} \frac{16}{5.86} \frac{17}{6.04} \frac{18}{6.22}$

RaninING CONTRACT YEARS:

PAnarrs:

$\frac{10-}{6.30} \frac{20}{6.53} \frac{21}{6.67} \frac{22}{6.81} \frac{23}{6.24} \frac{24}{7.00} \frac{25}{7.17} \frac{26}{7.28} \frac{27}{7.39}$

RDAintNo CONTRACT reass:

Panawrs:

$\frac{20}{7.49} \frac{29}{7.38} \frac{30}{7.67} \frac{31}{7.78} \frac{32}{7.84} \frac{33}{7.91} \frac{34}{7.99} \frac{35}{6.06}$




\section{APpenolx B}

\section{LEVEIIED FIXED ENERT PAMIENTS \\ (CENTS/Mnit)}

POR CUALIFYINO FACILITIES BEOINWING DELIVERY

DURING THE 1987-1998 PERICO

VEiR of conareanant of LEVELIZED CAPACITY PAMUaNTs:

1998

A. PRIOR FIXED ENEROY PAMENTS

\begin{tabular}{|c|c|c|c|c|c|c|c|c|c|c|c|}
\hline YEAR: & reor & TROS & YRos & riso & rest & reg2 & re93 & ra94 & YRes & ra96 & rR97 \\
\hline & $\bullet .60$ & 0.60 & 0.00 & 0.60 & 0.60 & 0.60 & 0.00 & 0.60 & 0.00 & 0.00 & 0.00 \\
\hline
\end{tabular}

b. SUESEOUaN Fixed ENcRer panmants

Renimine conmact reats:

\begin{tabular}{|c|c|c|c|c|c|c|c|c|}
\hline 1 & 2 & 3 & 4 & 5 & 6 & 7 & 6 & 9 \\
\hline & $\because$ & $\begin{array}{l}0.0 \\
0.0\end{array}$ & $\begin{array}{l}0 . \infty \\
0 . \infty \\
0 . \infty\end{array}$ & $\begin{array}{l}0.54 \\
0.34 \\
0.03\end{array}$ & $\begin{array}{r}0.92 \\
0.50 \\
1.07\end{array}$ & $\begin{array}{l}1.20 \\
0.76 \\
1.39\end{array}$ & $\begin{array}{l}1.42 \\
0.90 \\
1.65\end{array}$ & $\begin{array}{l}1.00 \\
1.02 \\
1.87\end{array}$ \\
\hline
\end{tabular}

Intsep

心 . REMintme contract resRs:

cot-ria

Mutsep

\begin{tabular}{|c|c|c|c|c|c|c|c|c|}
\hline 10 & 11 & 12 & 13 & 14 & 15 & 16 & 17 & 18 \\
\hline $\begin{array}{l}1.78 \\
1.12 \\
2.03\end{array}$ & $\begin{array}{l}1.09 \\
1.20 \\
2.20\end{array}$ & $\begin{array}{l}2.01 \\
1.20 \\
2.34\end{array}$ & $\begin{array}{l}2.12 \\
1.34 \\
2.47\end{array}$ & $\begin{array}{l}2.22 \\
1.41 \\
2.50\end{array}$ & $\begin{array}{l}2.30 \\
1.46 \\
2.60\end{array}$ & $\begin{array}{l}2.38 \\
1.51 \\
2.77\end{array}$ & $\begin{array}{l}2.46 \\
1.56 \\
2.86\end{array}$ & $\begin{array}{l}2.53 \\
1.61 \\
2.94\end{array}$ \\
\hline
\end{tabular}

ROAINTNO CONTRACT VEARS:

\begin{tabular}{|c|c|c|c|c|c|c|c|c|}
\hline 19 & 20 & 21 & 22 & 23 & 24 & 23 & 28 & 27 \\
\hline $\begin{array}{l}2.60 \\
1.65 \\
3.02\end{array}$ & $\begin{array}{l}2.66 \\
1.69 \\
3.09\end{array}$ & $\begin{array}{l}2.72 \\
1.72 \\
3.16\end{array}$ & $\begin{array}{l}2.77 \\
1.76 \\
3.23\end{array}$ & $\begin{array}{l}2.82 \\
1.79 \\
3.29\end{array}$ & $\begin{array}{l}2.87 \\
1.82 \\
3.34\end{array}$ & $\begin{array}{l}2.92 \\
1.85 \\
3.40\end{array}$ & $\begin{array}{l}2.98 \\
1.88 \\
3.45\end{array}$ & $\begin{array}{l}3.01 \\
1.91 \\
3.50\end{array}$ \\
\hline
\end{tabular}

OCT-Fer

MRT-Mar

$\begin{array}{llllllll}3.02 & 3.69 & 3.16 & 3.23 & 3.29 & 3.34 & 3.40 & 3.45\end{array}$

REMINIINO COMTRGT YEAPS:

oct-rus

matmar

Mar-sep

\begin{tabular}{|c|c|c|c|c|c|c|c|}
\hline 28 & 29 & 30 & 31 & 32 & 33 & 34 & 35 \\
\hline $\begin{array}{l}3.03 \\
1.93\end{array}$ & $\begin{array}{l}3.09 \\
1.96\end{array}$ & $\begin{array}{l}3.12 \\
1.90\end{array}$ & $\begin{array}{l}3.16 \\
2.0\end{array}$ & $\begin{array}{l}3.19 \\
2.02\end{array}$ & $\begin{array}{l}3.22 \\
2.04\end{array}$ & $\begin{array}{l}3.25 \\
2.00\end{array}$ & $\begin{array}{l}3.26 \\
2.08\end{array}$ \\
\hline
\end{tabular}




\section{appenoix $\mathrm{C}$ \\ VARIABLE BNEROY PAMMEMTS \\ FOR FIPAN POWER PURCAUSE CONTRACTS \\ (Conts/Mnit)}

FoR CUALIFYIMB FACILITIES BEGINAING DELIVERT

DURING THE 1907-1998 PERIDO

A. PRIOR varingLE ENDNOT PAMmants

\begin{tabular}{|c|c|c|c|c|c|c|c|c|c|c|c|}
\hline & reor & rios & rR69 & rR90 & re91 & YR92 & re93 & YR94 & YR93 & YR96 & YA97 \\
\hline $\begin{array}{l}\text { oct-rass } \\
\text { MAR-MAY } 3 \\
\text { NA-SEP A }\end{array}$ & $\begin{array}{l}1.23 \\
0.76 \\
1.43\end{array}$ & $\begin{array}{l}1.32 \\
0.84 \\
1.53\end{array}$ & $\begin{array}{l}1.43 \\
0.80 \\
1.60\end{array}$ & $\begin{array}{l}1.55 \\
0.90 \\
1.80\end{array}$ & $\begin{array}{l}1.07 \\
1.06 \\
1.95\end{array}$ & $\begin{array}{l}1.02 \\
1.15 \\
2.11\end{array}$ & $\begin{array}{l}2.60 \\
1.27 \\
2.35\end{array}$ & $\begin{array}{l}2.25 \\
1.43 \\
2.62\end{array}$ & $\begin{array}{l}2.40 \\
1.53 \\
2.60\end{array}$ & $\begin{array}{l}2.50 \\
1.63 \\
3.00\end{array}$ & $\begin{array}{l}2.70 \\
1.76 \\
3.23\end{array}$ \\
\hline
\end{tabular}

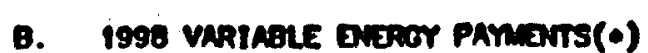

\begin{tabular}{|c|c|c|c|c|c|c|c|c|c|}
\hline REMIMINO CONTRACT VEARS: & 1 & 2 & 3 & 4 & $\mathbf{s}$ & 6 & 7 & 8 & 9 \\
\hline 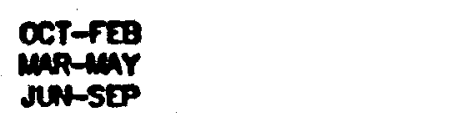 & $\begin{array}{l}3.12 \\
1.98 \\
3.63\end{array}$ & $\begin{array}{l}3.12 \\
1.98 \\
3.63\end{array}$ & $\begin{array}{l}3.15 \\
2.06 \\
3.67\end{array}$ & $\begin{array}{l}3.20 \\
2.03 \\
3.73\end{array}$ & $\begin{array}{l}2.72 \\
1.73 \\
3.17\end{array}$ & $\begin{array}{l}2.10 \\
1.53 \\
2.80\end{array}$ & $\begin{array}{l}2.18 \\
1.30 \\
2.53\end{array}$ & $\begin{array}{l}2.60 \\
1.27 \\
2.33\end{array}$ & $\begin{array}{l}1.87 \\
1.19 \\
2.18\end{array}$ \\
\hline REminino contract Vesps: & 10 & 11 & 12 & 13 & 14 & 15 & 16 & 17 & 18 \\
\hline 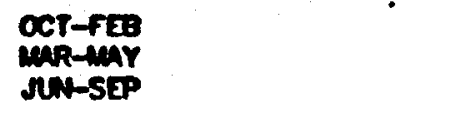 & $\begin{array}{l}1.77 \\
1.12 \\
2.05\end{array}$ & $\begin{array}{l}1.60 \\
1.67 \\
1.95\end{array}$ & $\begin{array}{l}1.61 \\
1.02 \\
1.87\end{array}$ & $\begin{array}{l}1.55 \\
6.90 \\
1.80\end{array}$ & $\begin{array}{l}1.49 \\
0.95 \\
1.74\end{array}$ & $\begin{array}{l}1.45 \\
0.92 \\
1.69\end{array}$ & $\begin{array}{l}1.41 \\
0.89 \\
1.84\end{array}$ & $\begin{array}{l}1.38 \\
0.87 \\
1.60\end{array}$ & $\begin{array}{l}1.34 \\
0.85 \\
1.56\end{array}$ \\
\hline RDMININO CONTRACT VeAFs: & 19 & 20 & 21 & 22 & 23 & 24 & 25 & 26 & 27 \\
\hline $\begin{array}{l}\text { oct-rua } \\
\text { MAR-AMr } \\
\text { ren-SEP }\end{array}$ & $\begin{array}{l}1.32 \\
0.84 \\
1.53\end{array}$ & $\begin{array}{l}1.29 \\
0.82 \\
1.50\end{array}$ & $\begin{array}{l}1.27 \\
0.81 \\
1.40\end{array}$ & $\begin{array}{l}1.25 \\
0.70 \\
1.46\end{array}$ & $\begin{array}{l}1.23 \\
6.70 \\
1.43\end{array}$ & $\begin{array}{l}1.22 \\
0.77 \\
1.41\end{array}$ & $\begin{array}{l}1.20 \\
0.78 \\
1.40\end{array}$ & $\begin{array}{l}1.19 \\
0.75 \\
1.38\end{array}$ & $\begin{array}{l}1.17 \\
6.75 \\
1.37\end{array}$ \\
\hline RвMIMINo contract Yens: & 28 & 29 & 30 & 31 & 32 & $\mathbf{3 3}$ & 34 & 33 & \\
\hline $\begin{array}{c}\text { oct-fes } \\
\text { mar-akr } \\
\text { ret-SEp }\end{array}$ & $\begin{array}{l}1.16 \\
0.74 \\
1.35\end{array}$ & $\begin{array}{l}1.15 \\
0.73 \\
1.34\end{array}$ & $\begin{array}{l}1.14 \\
6.72 \\
1.33\end{array}$ & $\begin{array}{l}1.13 \\
0.72 \\
1.32\end{array}$ & $\begin{array}{l}1.12 \\
6.71 \\
1.31\end{array}$ & $\begin{array}{l}1.12 \\
0.71 \\
1.30\end{array}$ & $\begin{array}{l}1.11 \\
0.70 \\
1.29\end{array}$ & $\begin{array}{l}1.10 \\
0.70 \\
1.20\end{array}$ & \\
\hline
\end{tabular}

(.) VARIABLE ENERAY PANMONTS FOR EACH CONTRACT VEAR AFTER 1990 MAY gE ESTIMATED OY INCREASING THE VALUES

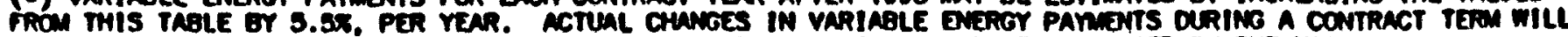

BE DETERAINTED OY THE RATE OF ESCALATION OF VARIAGLE COSTS ACTUALLY DXPERIENCED GY THE UTILITY. 


\section{appenolx 6}

YARIABLE ONERT PAMIIITS

FOR NON-FIFA POWR PURCULSE CONTRACTS

(cents/Mmi)

senson:

OCT-TE

mar-air

rutsep

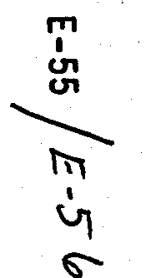

OCT-Feg

MaR-amy

ren-sup
YeNR

\begin{tabular}{|c|c|c|c|c|c|c|}
\hline Mror & rifos & rios & rise & mest & rR92 & YRPS \\
\hline $\begin{array}{l}1.23 \\
1.70 \\
1.43\end{array}$ & $\begin{array}{l}1.32 \\
.04 \\
1.35\end{array}$ & $\begin{array}{l}1.43 \\
8.90 \\
1.60\end{array}$ & $\begin{array}{l}1.55 \\
0.96 \\
1.80\end{array}$ & $\begin{array}{l}1.67 \\
1.08 \\
1.98\end{array}$ & $\begin{array}{l}1.02 \\
1.15 \\
2.11\end{array}$ & $\begin{array}{l}2.60 \\
1.27 \\
2.31\end{array}$ \\
\hline
\end{tabular}

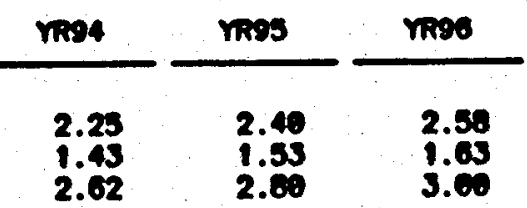


APPENDIX D

IDAEO POWER COMPANY

DEFINITION OF CAPACITY AND CAPACITY PAYMENT FOR

COGENERATION AND SMALI PONER PRODUCTION FACILITIES

\section{Contract Capacity}

The contract capacity of a gualifying facility is (1) the maximum one-hour reliable generating capacity of the facility if the full capacity of the facility is avaliable to and dispatchable by Idaho Power company at all times other than during scheduled maintenance periods and periods of forced outage, or (2) the contract annual firm energy production of the facility divided by the total hours in the year if the delivery of energy to Idaho Power Company is not dispatchable by the Company.

\section{Monthly Capacity Payment}

The monthly capacity payment to the qualifying facility during the contract perlod shail be the product of the contract capacity in kilowatts multiplied by the capacity payment per kilowatt. Capacity payments are based on the contract term and commerclal starting date of power delivery from the qualifying facility.

$$
E-57 / E-58
$$



Utah

The 1987 avoided cost rates used came from Public Service Commission Case \# 80-999-06 which gives an avoided cost of 3.9 cents/kWh. Kevin Higgins, Assistant Director for the Utah Energy Office, provided us with the $4 \%$ escalation rate (same as the inflation rate). The rates used for this state follow on the next page. 


\section{Utah}

\section{Meighted Averages}

\section{YEAR}

1987

1988

1989

1990

1991

1992

1993

1994

1995

1996

1997

1998

1999

2000

2001

2002

2003

2004

- 2005

2006

2007

2008

2009

2010
c/kWh

WEIGHTED AVG.

3.90

4.06

4.22

4.39

4.57

4.75

4.94

5.14

5.34

5.55

5.78

6.01

6.26

6.50

6.76

7.03

7.31

7.60

7.91

8.22

8.55

8.89

9.25

9.62 
- BEFORE THE PUBLIC SERVICE COMMISSION OF UTAR -

In the Matter of the Implementa-1 tion of Rules Governing Cogener-) ation and Small Power Production) in the State of Utah.
CASE NO. 80-999-06

REPORT AND ORDER
Appearances :

Fred W. Finlinson

Sheryl simpson

Lee M. Goodwin

Gregory Probst

Edward Bunter

Michael Ginsberg

Assistant Attorney General

David S. Christensen

Asisstant Attorney General
ISSOED: APri1 3,1987

For Sunnyside Cogeneration

- Otah Council of Independent Power Producers

- Utah Power Light Co.

- Division of Public utilities Department of Business Regulation, State of Utah

- Utah Energy office 
CASE NO. 80-999-06

TAELE OF CONTENTS

Page

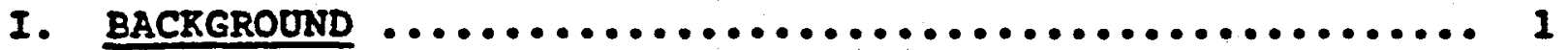

II. COMMISSION PHILOSOPHY $\ldots \ldots \ldots \ldots \ldots \ldots \ldots \ldots \ldots \ldots \ldots$.

III. FINAL POSITIONS OF PARTIES $\ldots \ldots \ldots \ldots \ldots \ldots \ldots \ldots \ldots \ldots$.

A. Final Position of Utah Power \& Light Company ........ 5

1. Inputs/Assumptions--Utah Power .............6 6

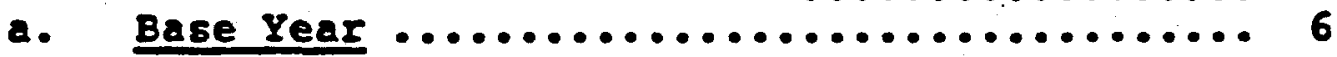

b. Load Forecast $\ldots \ldots \ldots \ldots \ldots \ldots \ldots \ldots \ldots \ldots \ldots 6$

c. Non-deferrable Generation Capacity $\ldots \ldots \ldots .7$

d. Committed QE Capacity ............... 7

e. Plant Life/Replacement/Refurbishment ...... 7

f. Assuned Annual Flow of New OF Capacity ..... 7

g. Exchange Capacity--Limits and Prices ...... 8

h. Deferrable Plant Characteristics and Costs $\ldots \ldots \ldots \ldots \ldots \ldots \ldots \ldots \ldots \ldots \ldots \ldots \ldots$

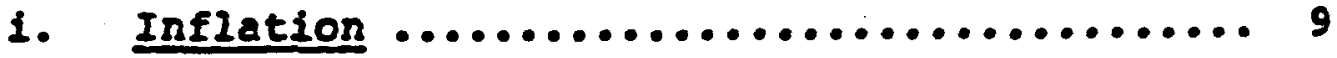

j. Tax and Depreciation Rates/Investment Tax Credit ........................ 9

k. Cost of Capital ...................... g

1. Energy Credit ....................... 9

m. Surplus (Non-Tariff) sales .............. 10

2. QF Capacity and Energy Prices--Utah Power ...... 10

a. Capacity Price .................... 10

b. Energy Price $\ldots \ldots \ldots \ldots \ldots \ldots \ldots \ldots \ldots \ldots \ldots$

3. The Floor and Balancing Account--Utah Power ..... 10

4. Annual Limit--The Cap--Utah Power $\ldots \ldots \ldots \ldots \ldots 10$ 
B. Final Position of the Division of Public otilities ... 11 1. Inputs/Assumptions--The Division ............ 11

a. Load Forecast ..................... 11

b. Plant Life/Replacement/Refurbishment ...... 11

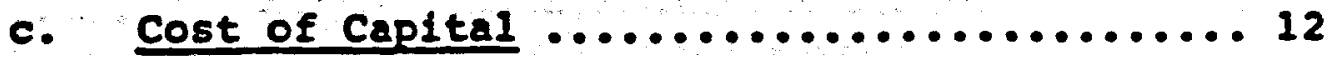

d. Energy Credit ..................... 12

2. QF Capacity and Energy Prices-The Division ..... 12

a. Capacity Price $\ldots \ldots \ldots \ldots \ldots \ldots \ldots \ldots \ldots \ldots 12$

b. Energy Price $\ldots \ldots \ldots \ldots \ldots \ldots \ldots \ldots \ldots \ldots \ldots 12$

3. The Floor and Balancing Account--The Division ... 12

4. Capacity Limitation--The Cap--The Division ...... 13

c. Final Position of the Utah Energy office $\ldots \ldots \ldots \ldots \ldots 13$

1. Inputs/Assumptions-UEO $\ldots \ldots \ldots \ldots \ldots \ldots \ldots \ldots \ldots$

a. Load forecast $\ldots \ldots \ldots \ldots \ldots \ldots \ldots \ldots \ldots \ldots \ldots 13$

b. Plant Life/Replacement/Refurbishment ...... 13

c. Assumed Annual Flow of New QF Capacity ..... 14

d. Deferrable plant orM Cost ............... 14

e. Cost of Capital ...................... 14

f. Energy Credit ..................... 14

2. QF Capacity and Energy Prices-UEO $\ldots \ldots \ldots \ldots \ldots 14$

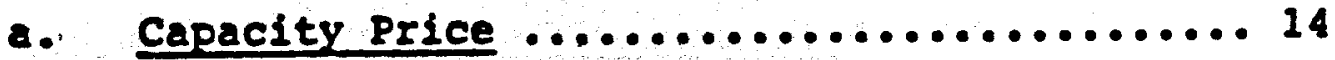

b. Energy Price ..................... 15

3. The Floor and the Balancing Account--UEO ....... 15

4. Annual Limit--The Cap--UEO $\ldots \ldots \ldots \ldots \ldots \ldots \ldots \ldots 15$

5. Diversity-UEO $\ldots \ldots \ldots \ldots \ldots \ldots \ldots \ldots \ldots \ldots \ldots \ldots$

D. Final Position of the Utah Councll of Independent Power Producers $\ldots \ldots \ldots \ldots \ldots \ldots \ldots \ldots \ldots \ldots \ldots \ldots \ldots \ldots$

1. Inputs/Assumptions-UCIPP $\ldots \ldots \ldots \ldots \ldots \ldots \ldots \ldots$

a. Load Forecast $\ldots \ldots \ldots \ldots \ldots \ldots \ldots \ldots \ldots \ldots 16$

b. Plant Life/Replacement/Refurbishment ...... 16

c. Deferrable Plant Costs ............... 16

d. Energy Credit $\ldots \ldots \ldots \ldots \ldots \ldots \ldots \ldots \ldots \ldots \ldots \ldots$

e. Cost of Captal $\ldots \ldots \ldots \ldots \ldots \ldots \ldots \ldots \ldots 17$

f. Working Capital $\ldots \ldots \ldots \ldots \ldots \ldots \ldots \ldots \ldots 17$ 
CASE NO. 80-999-06

Page

2. QF Capacity Price--UCIPP ................. 17

3. Further Discussion ...................... 17

E. Final Position of Sunnyside Cogeneration Associates .. 18

1. Inputs/Assumptions--Sunnyside

a. Committed QF Capacity ................. 18

b. Plant Life/Replacement/Refurblshment ...... 19

2. QF Energy Price-msunnyside .................. 19

3. The Floor and Balancing Account--sunnyside ...... 19

4. Annual Limit--The Cap--Sunnyside ............. 19

IV. DISCUSSION, FINDINGS AND CONCLUSIONS $\ldots \ldots \ldots \ldots \ldots \ldots \ldots \ldots$

A. Capacity Cost Calculation Assumptions ............ 21

1. Consensus assumptions ................... 21

2. Assumptions Subject to Disagreement ........... 22

a. Load Forecast ....................... 22

b. Plant Refurbishment/Retirement/

Replacement ........................ 23

c. Treatment of the Sunnyside Cogeneration

Associates Facility ................. 23

d. Deferrable Plant Construction/Capital

Cost ...........................24

e. Deferrable Plant OSM Cost .............. 24

f. Deferrable plant Energy Credit ............ 24

g. Assumptlons Regarding Cost of Capltal ..... 25

h. Summary of Findinas on Assumptions Subject to Disagreement $\ldots \ldots \ldots \ldots \ldots \ldots \ldots . . \ldots 26$

B. QF Capacity Price $\ldots \ldots \ldots \ldots \ldots \ldots \ldots \ldots \ldots \ldots \ldots \ldots \ldots \ldots \ldots \ldots \ldots$

C. Annual of Capacity Limit--The Cap ............... 28

D. Rloht to Recalculate and Suspend $\ldots \ldots \ldots \ldots \ldots \ldots \ldots$

E. $\quad$ gE Energy Price $\ldots \ldots \ldots \ldots \ldots \ldots \ldots \ldots \ldots \ldots \ldots \ldots \ldots \ldots \ldots \ldots \ldots \ldots$

1. Avoided Energy Cost ..................... 30

2. The Energy Floor and the Balancing Account ..... 31 
F. Contract rerm $\ldots \ldots \ldots \ldots \ldots \ldots \ldots \ldots \ldots \ldots \ldots \ldots \ldots \ldots \ldots \ldots \ldots$

v. ORDER $\ldots \ldots \ldots \ldots \ldots \ldots \ldots \ldots \ldots \ldots \ldots \ldots \ldots \ldots \ldots \ldots \ldots \ldots \ldots \ldots \ldots \ldots \ldots \ldots$

A. QF Capacity Price--20-Year Contract .............. 33

B. $\quad$ gF Capacity Price--30-Year Contract .............. 33

c. $\quad$ gE Energy Price $\ldots \ldots \ldots \ldots \ldots \ldots \ldots \ldots \ldots \ldots \ldots \ldots \ldots \ldots \ldots \ldots$

D. The Floor and the Energy Payments Balancing

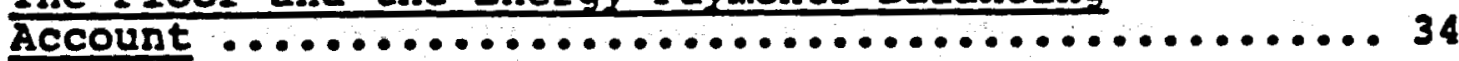

E. Annual Limit-The Cap $\ldots \ldots \ldots \ldots \ldots \ldots \ldots \ldots \ldots \ldots \ldots \ldots \ldots$

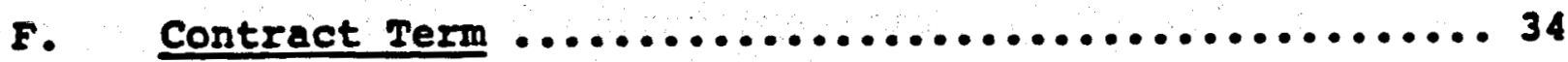

G. Duration of order $\ldots \ldots \ldots \ldots \ldots \ldots \ldots \ldots \ldots \ldots \ldots \ldots \ldots \ldots \ldots$

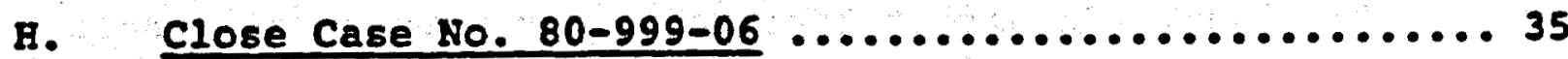

I. Phase II--Redesign of Methodology ............... 35 
By the Comrissior:

\section{BACKGROUND}

This case was instigated by the filing of an application by Otah Power and Light Company (Utah Power, the Company) to reduce the prices offered by the company for the capacity and energy of FERC-certified Qualifying Facility (QF) cogenerators and small power producers (1.e., the "buy back" rates). These prices were established in our Report and order in this case, dated Merch 14, 1985. The application requested that capacity prices be recalculated using relevant current data, estimates, and projections. In direct testimony, the Company requested that the capacity price for 20-year contracts be reduced from $\$ 202$ to \$158 per $\mathrm{kW}-\mathrm{yr}$ based on an assumed $15 \mathrm{~kW}$ per year expected future increase in $Q F$ capacity. The Company further requested that the energy price be reduced from 21 to $13 \mathrm{mills}$ per $\mathrm{kWh}$, and that the energy price floor of 20 mills per kWh be removed entirely.

On July 18, 1986, the Company filed an application for the suspension of availability of new $Q F$ contracts at current capacity and energy prices. The Commission decided to reopen Care No. 80-999-06, to require the Company to file new avoided cost data, and to determine what, if any changes should be made to the existing avolded cost based prices. Notice was given, and a prehearing conference was held on August 6, 1986. on September 30, 1986, the Company submitted the prefiled testimony of several witnesses. Testimory was also fllec by the 
staff improved the operation of this model such that it could be used quickly and easily to compute the avoided capacity cost derived from any set of Input assumptions. This version was made available to all parties and was used by most parties to develop their final positions. The avallability of this model allowed the hearing to focus on the approprlateness of proposed input assumptions. Once these issues were settled, the computation of the resulting capacity prices, as crdered herein, was carried out by Commission stafe.

The hearing also addressed the issue of the determination of the avoided cost based price for $Q F$ energy. Questions dealing with the appropriate values were resolved and the resulting $Q F$ energy price established.

Many issues regarding specific quentitative assumptions were discussed et a Comission-ordered technical conference in which representatives of the parties and the commission's staff participated. This conference lead to the resolution of a number of significant disagreements which existed in the parties prefiled testimony, thereby eliminating the need for extensive argumentation on these points in the hearing. The technical conference also lead to the clarification of points of disagreement, thereby enhancing the efficlency with which the hearing was conaucted. 


\section{CASE NO. 80-999-06 \\ $-5-$}

To implement this philosophy, our policy is to set prices for $Q F$ cepacity and energy which reflect market conditions, including the value of existing generation capacity surpluses or shortages, and to change these prices as market conditions change. Our intention is that the responses of $Q F$ developers to these market signals will serve to keep realized development in Iine with that level of development which serves the Interests of the ratepayers without unduly subsidizing the $Q F$ developers. Specificaily, lower QF capacity prices in periods of excess capacity reflect the limited value to ratepayers of aditional capacity. Such prices are likely to limit the guantity of $Q F$ capacity that will be developed. In periods of capacity shortage, higher capacity prices would reflect the higher value to ratepayers of aditional capacity. Such higher rates would be expected to result in a more rapid development of realized QF capacity. He recognize that our reliance on this surrogate for market forces to promote efficient investment in QF capacity may prove inadequate. In such event, direct intervention may be required to suspend purchase of new of capacity and/or to establish new $Q F$ capacity and energy prices.

\section{FINAL POSITIONS OF PARTIES}

This section summarizes the position arrived at by each party at the end of the hearing. Input assumptions and resulting capacity and energy prices as well as certain operational/policy matters are considered. The Company's final position will be 
forecast was prepared. Since that forecast reflected none of those changes, it was an outdated and inaccurate picture of future Ioad requirements.

c. Non-deferrable Generation Capacity: The Company's current generation capacity is 3161 MW. Additional nondeferrable capacity consists of $60 \mathrm{wW}$ at IPP starting in 1987, $21 \mathrm{NW}$ at Gem State starting in 1989 (summers only), and $15 \mathrm{MW}$ of geothermal sterting in 1992 .

d. Committed OF Capacity: OF capacity to which the Company is already committed will rise from $8 \mathrm{MW}$ in 1986 to $22 \mathrm{MW}$ by the winter of 1987. It will remain at this level until the 45 MW Sunnyside Cogeneration Associates project comes on line in the winter of 1990 .

e. Plant Iife/Replacement Refurbishment: The Company contended that no evidence had been presented which would justify an increase in avolded capacity costs due to retirement or refurbishment of the Company's existing units. The Company stated that it had no plans to retire any units during the 20-year forecast period used to determine avoided capacity costs.

F. Assumed Annual Flow of New OF Capacity: The Company postulates future growth of $Q F$ capacity to be 15 MW per year starting in 1987. reaching a level of $300 \mathrm{~kW}$ in 2006. This capacity should be assumed to operate with a load factor of 75 percent. This new capacity is in addition to committed $Q F$ capacity. It represents the new $Q F$ developments which would be subject to the pricing and policy decisions made in this and 
CASE NO. 80-999-06

$-9-$

capitalized plant cost. The plant would have a book life of 35 years and would operate with a 75 percent capacity factor.

i. Inflation: The Company supports the use of a four percent general inflation rate.

j. Tax and Depreciation Rates/Investment Tax Credit: The Company asserted that tax rates, the modified Accelerated Cost Recovery System (ACRS), and treatment of the Investment Tax Credit (ITC) associated with the new federal tax laws should be used. The composite income tax rate 1s, therefore, 37.2 percent and the ITC rate is zero $(0)$ percent. Reguired changes in the ACRS were incorporated into the revenue reguirement formule component of the avoided capacity cost computation.

k. Cost of Capitel: The Company's position is that its current realized capital structure and rates of return on debt and preferred stock, and authorized rate of return on common equity should be used in computing cost of.capital. The capital structure should be 48.7 percent debt, 5.6 percent preferred, and 45.7 percent common. Rates of return should be 9.75 percent on debt, 8.13 percent on preferred, and 15 percent on common. The resulting cost of capitel is 12.06 percent.

1. Energy Credit: The Company proposed a figure of 7 mil1s per kWh for the energy credit required by the sca method to correct the potential overpayment associated uith paying QF's marginal energy coste even though capacity payments are based on displacing base-load units having lower energy costs. 
capacity assumed in calculating the price; 1.e., to the $15 \mathrm{WW}$ per year recommended in subsection III.A.1.f., above.

B. Final Position of the Division of Public Otilities

The Division's case was presented by Nile . Eatmon. He developed a set of assumptions and calculated and presented the resulting capacity price. Be also presented a $Q F$ energy price and recommended a price floor-balancing account mechanism for dealing with energy payments. Mr. Eatmon's assumptions will be discussed in section 1. Presentation of other aspects of the Division's position will follow.

\section{Inputs/Assumptions--The Division}

As indicated, consensus regarding most SCA inputs/ assumptions was reached in the technical conference. Only those. inputs/assumptions concerning which the Division maintained a different position are discussed here.

a. Load Forecast: The Division recommended using the forecast developed by commission staff in the spring of 1986, as modified by Utah power personnel in the Hunter III sale case, Case No. 85-035-08.

b. Plant Life/Replacenent/Refurbishment: Though the original SCA did not adjust for retirement of generating plants, the Division recognized that utah power can avold paying new plant cost by refurbishing existing plant. The Division therefore recommended that in calculating avolded cost, it should be ascumed that plant is refurbished at the 45 th yeer of its life at a cost equal to one-half of then-current new plant construction costs. 
mills unt1l the accumulated overpayment plus accumulated interest is eliminated. The Division testified that its proposal provides stable revenues for the $Q F$ while preventing any subsidy by ratepayers.

4. Capacity IImitation-The Cap-The Division

The Division agrees with the Company's proposal for a 15 per year cap on the amount of $O F$ capacity accepted. The Commission should establish guidelines on how the 15 MW would be allocated by distinguizhing projects on the basis of price, terms of the contract, type of resource, location, reliability, security, and other factors. According to the Division, projects that provide reliable service at the lowest possible costs should receive priority.

c. Final Position of the Utah Energy Office

tEO witness Revin Higgins proposed a number of assumptions which differed from those of most of the other parties. These assumptions are addressed in section 1. Resulting price proposals and a number of pollcy suggestions follow..

1. Inputs/Assumptions--UEO

a. Load forecast: The average of the Commission staff spring, 1986, forecast and the forecast presented by Utah Power witness Eutchinson should be used.

b. Plant Life/Replacement/Refurbishment:

Existing Dtah Power facilities should be assumed to be retired and replaced at 45 years of age. 
CASE NO. 80-999-06

$$
-15 \text { - }
$$

b. Energy Price: UEO contends that avoided marginal energy cost should be calculated as 125 percent of system average energy cost.

3. The Floor and the Balancing Account--UEO

The UEO's position on the energy floor is that it should be $10 w e r e d$ from 20 mills to 18 mills to account for lower energy costs. UEO argues both ratepayer and OF interests would be best served by setting the price for $Q F$ energy equal to 125 percent of syster average energy cost because the existing method Ylelds results which are volatile, assumption-sensitive, and open to dispute. The current approach will encourage future decision making by the utility which may not be economically efficient.

4. Annual Iimit-The Cap-UEO

The UEO agrees that a "cap" on OF capacity should be initiated. Approval of front-end loaded contracts should be restricted so the total system OF capacity grows no more than $30 \mathrm{WW}$ per year. This cap should apply to new $\mathrm{QF}$ capacity and the sunnyside profect, os well as to $Q F$ capacity currently under contract in utah Power's Idaho or Hyoming service territory, or is otherwise considered "comitted."

5. Diversity-0EO

To allow some diversity of opportunity and of resource development, JEO advocates that five MW of capacity should be "reserved" each year for Utah renewable energy (nor-cogeneration) projecte. Because $Q F$ capacity will be limited, an equitable and acministratively-feasible rationing procedure, basea or factors 
CASE NO. 80-999-06

$-17-$

e. Cost of Capital: UCIPP proposes an "idealized" capital structure and rate of return on its components. Their proposed structure is 45 percent each for debt and common and 10 percent for preferred, with rates of return of 10.1 percent on debt, 9.40 percent on preferred, and 15 percent on common. This produces a cost of capital value of 12.24 percent.

f. Horking Capital, UCIPP proposes 2.08 percent of plant cost as a working capital requirement figure. All other parties accept 2.02 percent. The difference is too small to affect the resulting capacity price calculation.

\section{QF Capacity Price--UCIPP}

The avoided cost based capacity price derived from the UCIPP assumptions and proposed by them for a 20-year QF contract is $\$ 258 / \mathrm{kW}-\mathrm{yr}$.

\section{Eurther Discussion}

UCIPP and Snowbird Development Company President A. Colin Jackson discussed UCIPP's purpose, positions, and historical participation in Case No. 80-999-06. Don R. Asher of Power Systems Engineering discussed the difficulty of developing QF's, stated that $Q F$ "oversupply" statements of utilities are unfounded, and suggested that a project development milestone procedure would be desirable.

William B. Marcus of JBS Energy, provided an alternative method for QF pricing and commented on avolded energy cost calculation methods and other contractual 18sues. Mr. Marcus proposed that the Commission allow Utah Power to defer some of the capacity costs of QF's instead of immediately collecting them 
existing projects and commitments into consideration. Sunnyside's proposal could be used with or without an annual cap on capacity.

b. Plant Life/Replacement/Refurbishment: Sunnyside argued that the assumption of an unlimited life for Utah Power plants is inappropriate in light of the realities of utility plant experience, and particularly in light of the significant expenses associated with power plant refurbishment. Sunnyside recommends that rehabilitation costs be included in the model at 40 percent of the replacement cost, and that the life extension. be Included as 20 years.

\section{QF Energy Price--Sunnyside}

Sunnyside agrees that VEO's proposal to use 125 percent of Utah Power's average energy cost is the most practical method to establish the $Q F$ energy price.

\section{The Floor and Balancing Account--Sunnuside}

Sunnyside recommends that the energy floor be retained, with a balancing account similar to that approved by the comission in the Sunnyside proceeding (Case No. 86-2018-01).

4. Annual Iimit--The Cap--Sunnyside

Sunnyside does not object in principal to the concept of an annual cap on QF capacity, but specific problems ano issues must be resolved in implementing a cap. These include the manner in which single projects with capacity in excess of the annual cap will be treated. The cap should be administered so that once a project's contract has been approved by the cormission, that 
CASE NO. 80-999-06

$-22-$

A. Capacity Cost Calculation Assumptions

1. Consensus Assumptions

As indicated in the summary of parties' positions, all parties have agreed to a number of input assumptions. These are set out in the following table. We find them appropriate for use in this case.

Consensus Capacity Payment Input Assumptions Item Value

Base Year 1987

Inflation Rate 4.08 per year

Composite Corporate Income

Tax Rate (Federal plus state)

37.28

Investment Tax Credit Rate

0.08

MW Per Year New Cogeneration

15 MT per year*

Cogeneration Load Factor

758

\section{Exchange Capacity Purchases}

Summer Months

Tranemission Iimitation on

Sumner Exchange Purchases

Price (In 1985 Dollars)

Winter Months Winter Exchange Purchase Price (In 1985 Dollars)
3 months per year

$210 \mathrm{MW}$

$\$ 2.31$ per $k w-m o$

6 months per year

$\$ 4.42$ per $k W-m o$

Deferrable Plant

Net Capacity

Book Iife

Capacity Factor

Other Fixed Costs (s of Capital Cost)

Working Capital

Ad Valoren Taxes

Insurance
$100 \mathrm{MH}$

35 years

758
$2.028 * *$
1.178
0.188

Non-Tariff Sales

Margin

$6.0 \mathrm{mil1s}$ per $\mathrm{kmh}$ Probability

378

* UEO also considers 30 Mi per year case

* UCIPP maintains 2.088 ; the difference is insignificant. 
of a major growth spurt in the second decade of the 20-year projection interval to be questionable at best.

The UEO forecast, being an average of the PSC and UPCL forecasts, is a reasonable resolution of the issues discussed above. Therefore the commission finds that the uEo forecast is appropriate and acceptable for use in this case.

b. Plant Refurbishment/Retirement/Replacement: We find it appropriate to consider replacement or refurbishment of existing plant in the SCA procedure's "capacity expansion plan" component. The UEO proposal to impose the assumption of retirement and replacement at a plant life of 45 years appears unrealisticaliy restrictive. The Division proposal to approximate the complex process of gredual and continuous upgrade and refurbishment with an assumed one-time capital expenditure equal to one-half the cost per kilowatt of buliding new plant, with the expenditure occurring at the 45 th year of plant. Iffe, is the best option avaliable on the record for dealing with this complex 1ssue. Thus, we adopt the Division's refurbishment proposal for this case.

c. Treatment of the Sunnyside Cogeneration Associates Facility: Fe find that the most reasonable and equitable treatment of the sunnyside facility is to assign thet facility's 45 ITh to the "Committed Cogeneration" category of the sCA procedure in mid-yeer 1990, and to impose no associated reduction in the assumed $15 \mathrm{~kW}$ per year stream of new of capactey upon which the avolded cepacity cost caiculation is based. This procedure 


\section{CASE NO. 80-999-06 $-25-$}

it is appropriate to rely on an approach utilizing the actual values. The Division and the Company both present actual marginal cost based energy credit proposals. The Division proposes 5.0 mills per $\mathrm{kWh}$, while the Company proposes $7.0 \mathrm{mills}$ per $\mathrm{kWh}$. The evidence is insufficient to affirm the propriety of either proposal. We, therefore, find that the average of the two, 1.e.. $6.0 \mathrm{mills}$ per $\mathrm{kWh}$, is appropriate for use in this case.

9. Assumptions Regarding Cost of Capital: since the Company's actual capital structure would impose the costs subject to deferral by QF capacity, no proposal to use any other capital structure, however derived, is acceptable in this case. We, therefore, find that the Company's actual capital structure, as listed below, 18 appropriate for use in this case.

Rates of return on debt and preferred stock should reflect current returns on these components since they are unlikely to change significantly in any predictable way in the future. The Division's proposal to use a lower value for return on common equity rather than the current allowed rate reflects the reasonable assumption that the cost of capital under current market conditions is at least 100 basis points 1 ess than the Company's current authorized rate. Thus the Division's recommended 14 percent per year for the rate of return on common is selected as the most appropriate figure on the record. The capital structure and rate of return figures found appropriate and accepted for use in this case are set out in the following table. The resulting cost of capital is 11.60 percent. 
CASE NO. 80-999-06

$-27-$

Contested Inputs/Assumptions and 20-Year Contract Capac1ty Price

Sumary of Parties' Posielons

and Comission Findings

\begin{tabular}{|c|c|c|c|c|c|c|}
\hline \multirow[b]{2}{*}{ Input/Assumption } & \multicolumn{5}{|c|}{ Proposing Party } & \multirow[b]{2}{*}{$\begin{array}{c}\text { Comonission } \\
\text { Finding }\end{array}$} \\
\hline & UPEL & DPO & UEO & DCIPP & $\begin{array}{l}\text { Sunny- } \\
\text { side* }\end{array}$ & \\
\hline Load Forecast (MN) & $\begin{array}{l}\text { TREL } \\
\text { Assump } \\
\end{array}$ & $\begin{array}{r}\text { PSC } \\
\text { ns Re1 } \\
\end{array}$ & $\begin{array}{r}\text { OEO } \\
\text { ro D } \\
\end{array}$ & $\begin{array}{l}\text { PSC } \\
\text { ble PI }\end{array}$ & & UEO \\
\hline $\begin{array}{l}\text { Cep1tal Cost (\$/kH) } \\
\text { osM Cost m11ls/kWh } \\
\text { Energy Cred1t } \\
\text { (mf11s/kHh) }\end{array}$ & $\begin{array}{r}\$ 1.489 \\
5.79 \\
7.00\end{array}$ & $\begin{array}{r}\$ 1,489 \\
5.79 \\
5.00\end{array}$ & $\begin{array}{r}\$ 1.549 \\
7.60 \\
3.50\end{array}$ & $\begin{array}{r}\$ 1.771 \\
9.86 \\
3.00\end{array}$ & - & $\begin{array}{r}\$ 1.489 \\
5.79 \\
6.00\end{array}$ \\
\hline
\end{tabular}

Assumptions Related to Cost of Capital

\begin{tabular}{|c|c|c|c|c|c|c|}
\hline \\
\hline & 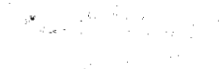 & \multicolumn{2}{|c|}{ Capieal structure } & \multirow[b]{2}{*}{$\begin{array}{l}45.008 \\
10.008 \\
45.002\end{array}$} & & \multirow[b]{2}{*}{$\begin{array}{r}48.70 x \\
5.60 \% \\
45.70 \%\end{array}$} \\
\hline $\begin{array}{l}\text { Percent Debt } \\
\text { Percent Preferred } \\
\text { Percent Common }\end{array}$ & $\begin{array}{r}48.70 z \\
5.602 \\
45.708\end{array}$ & $\begin{array}{r}48.70 \% \\
5.60 \% \\
45.70 \%\end{array}$ & $\begin{array}{r}48.70 z \\
5.60 \% \\
45.70 \%\end{array}$ & & $-\infty$ & \\
\hline \multicolumn{7}{|c|}{ Rate of Return (2 per year) } \\
\hline $\begin{array}{l}\text { Debt } \\
\text { Preferred } \\
\text { Common } \\
\text { Cost of Capital }\end{array}$ & $\begin{array}{r}9.75 \% \\
8.13 \% \\
15.00 \% \\
12.05 \%\end{array}$ & $\begin{array}{r}9.75 \% \\
8.13 \% \\
14.00 \% \\
11.60 \%\end{array}$ & $\begin{array}{r}9.807 \\
8.10 z \\
14.00 \% \\
11.628\end{array}$ & $\begin{array}{l}10.10 \% \\
9.40 \% \\
15.00 \% \\
12.24 \%\end{array}$ & $-\infty$ & $\begin{array}{r}9.75 \% \\
8.13 \% \\
14.00 \% \\
11.607\end{array}$ \\
\hline Plant Retirement & none & refurb** & $\begin{array}{l}\text { retire } \\
45 \text { years }\end{array}$ & refurb** & refurb** & refurb** \\
\hline $\begin{array}{l}\text { Treatment of } \\
\text { Raiser Sungyside }\end{array}$ & Cominiced & $=$ & $=$ & - & Committed & Comenitted \\
\hline $\begin{array}{l}\text { Indicated Capacity } \\
\text { Price ( } \$ \text { per lH-gr) } \\
\text { 20-lear Contract }\end{array}$ & $\$ 151$ & $\$ 177$ & $\$ 196$ & $\$ 258$ & $=$ & $\$ 160 * * *$ \\
\hline
\end{tabular}

- Sunpyelde expresses general agreement ulth OEO on most assumptions.

* Refurb1shment: 50 percent of Otah Power's AFBC plent new constructior cost wth associated OsM expense adjustment. UCIPP maintains that refurbishment should be costed at 40 percent of nev plant capltal cost. ThIs adjustnent adds one dollar per kH-gr to the capacity cost figure produced by the model.

*** The Comission computes the 30-year contract cspacity price to be $\$ 171$ per $k$ h'-gr for QF's which qualify for a 30 -gear contract. 
plus accumulated, as yet unused, portions of previous years' limits, at the existing approved capacity price. Any proposed QF contract which would exceed a given year's accumulated cap limit would trigger a recalculation of the avoided capacity cost using the SCA procedure and then-current input assumptions. In this recalculation, the capacity associated with all of contracts signed to that date, and of the particular project that triggers the recalculation, i.e.. of the project whose capacity would exceed the accumuleted cap, will be included in the "committed cogeneration" category. Upon recalculation, the project which triggered the recalculation would have the option of accepting the newly calculated $Q F$ capacity price offer. If the new price is accepted, it then becomes the new approved price and remains in force until a subsequent recalculation occurs. If it is not accepted, the previous approved price remains in effect for all QF's which do not exceed the accumulated cap. The QF project which triggered the recalculation would, of course, still be ineligible for the previous price, at least until a later year, since its capacity would still exceed the accumulated cap limit in the current year.

This procedure protects against a glut of overpriced $Q F$ capecity while permitting the Company and its ratepayers to take advantage of any level of $Q F$ capacity which may be forthcoming at capacity prices which meet the test of ratepayer neutrality. The Commission's concern is not to prevent the development of any specific quantity of OF capacity, rather it is to insure that any 
CASE NO. 80-999-06

$-31-$

of energy is approximately $13 \mathrm{mills}$ per $\mathrm{kWh}$. The Company proposes that this figure be adopted as the OF energy price. UEO proposes that marginal energy cost be estinated as 125 of system average energy cost. The Commission finds that the Company's ablilty to measure system marginal energy cost is sufficiently reliable and accurate that the expediency of a ogo-type estimate is not justified. Thus, we find that the company's proposed marginal energy cost figure of 13 wills per kWh is appropriate for use in this case. We further find that in future years, measured actual system marginal energy costs should be the basis for QF energy prices and for energy credit calculation.

2. The Energy Floor and the Balancing Account

The Commission finds that the public interest is served by assuring a rellable revenue stream for $O F$ projects. To achieve this objective, the energy price floor mechanism will be maintained. The floor value will be set at 13 mills per $\mathrm{kWh}$.

The Commission recognizes that if realized marginal energy cost drops below the $13 \mathrm{mills}$ per kwh figure, the floor by itself would impose a subsidy from the ratepayers to the QF's, thereby violating the principle of ratepayer neutrality. To remedy this eltuation, we find that an interest-bearing energy payment balancing account should be established for each QF with the interest rate being equal to, and changing with, the rete applied to the Company's Energy Balancing Account. This rate is currently nine (9) percent. (Note: This energy payments baiancing account is separate from and for a different purpose than the balancing account established in the 1985 order.) 
D. The Floor and the Energy Payments Balancing Account

The minimum energy price, or floor, will be 13 mills per $k w h$ and will remain at this level, unless changed by the Commission, in any year in which measured realized system marginal energy cost is less than the minimum. An interest-bearing energy payments balancing account will be established for each $O F$ and will operate as discussed in Section IV.E.2. Balances in the account will accrue interest at the rate established for the company's Energy Balencing Account, 1.e., at nine (9) percent currently.

E. Annual Limit--The Cap

These QF prices will be avallable to all new QF's up to a maximum accunulated contracted new $Q F$ capacity of 15 wW per year. The $Q F$ capacity price will be recalculated, as described in Discussion, Findings and Conclusions above, any time an applicant QF offers capacity which would cause accumulated $Q F$ capacity to exceed the accumulated capacity ifmitation for the year in which that facility would come on 2ine. The triggering facility will face the recalculated capacity price, which will become the standing offer price if it is accepted.

\section{F. Contract Term}

The standard QF contract will be for a 20-year term. Any oF developer applying for a longer term contract will be required to meet the renewable resource/fuel cost stability test established in the 1985 order. A positive chowing before the Commission that the project meets the test will be required for approval of any extended term contract. 


\section{G. Duration of Order}

These provisions will remain in effect until further notice from this Commission. The Commission may institute a proceeding to recalculate prices, and may suspend purchase of new OF capacity at the rates established in this order at any time, when in its judgment, changing market conditions and the public iriterest warrant.

H. Close Case No. 80-999-06

With this order the Commission will close Case No. 80-999-06. Henceforth, al1 actions concerning cogeneration and small power production will be assigned to separate dockets.

\section{Phase II--Redesign of Methodology}

The Commission will establish an investigative cocket for the purpose of reconsidering methods for calculating avoided cost based capacity and energy prices. A prehearing conference will be called by the commission for the purposes of ldentifying parties and scheduling proceedings. It is our intention at this time that the proceeding will begin with a technical conference, chaired by staff. staff is instructed to prepare and circulate to parties a memorandum introducing the subject.

DATED at Salt Lake City, Utah, this 3rd day of April. 1987.

L/ Brian T. Stewart, Chairman

(SEAI) /s/ Brent H. Cameron, Commissioner

Attest: /8/ James M. Eyrne, Commissioner

/s/ Stephen c. Hewlett 



\section{APPENDIX F \\ ROYALTIES PROGRAM COMPUTER CODE}





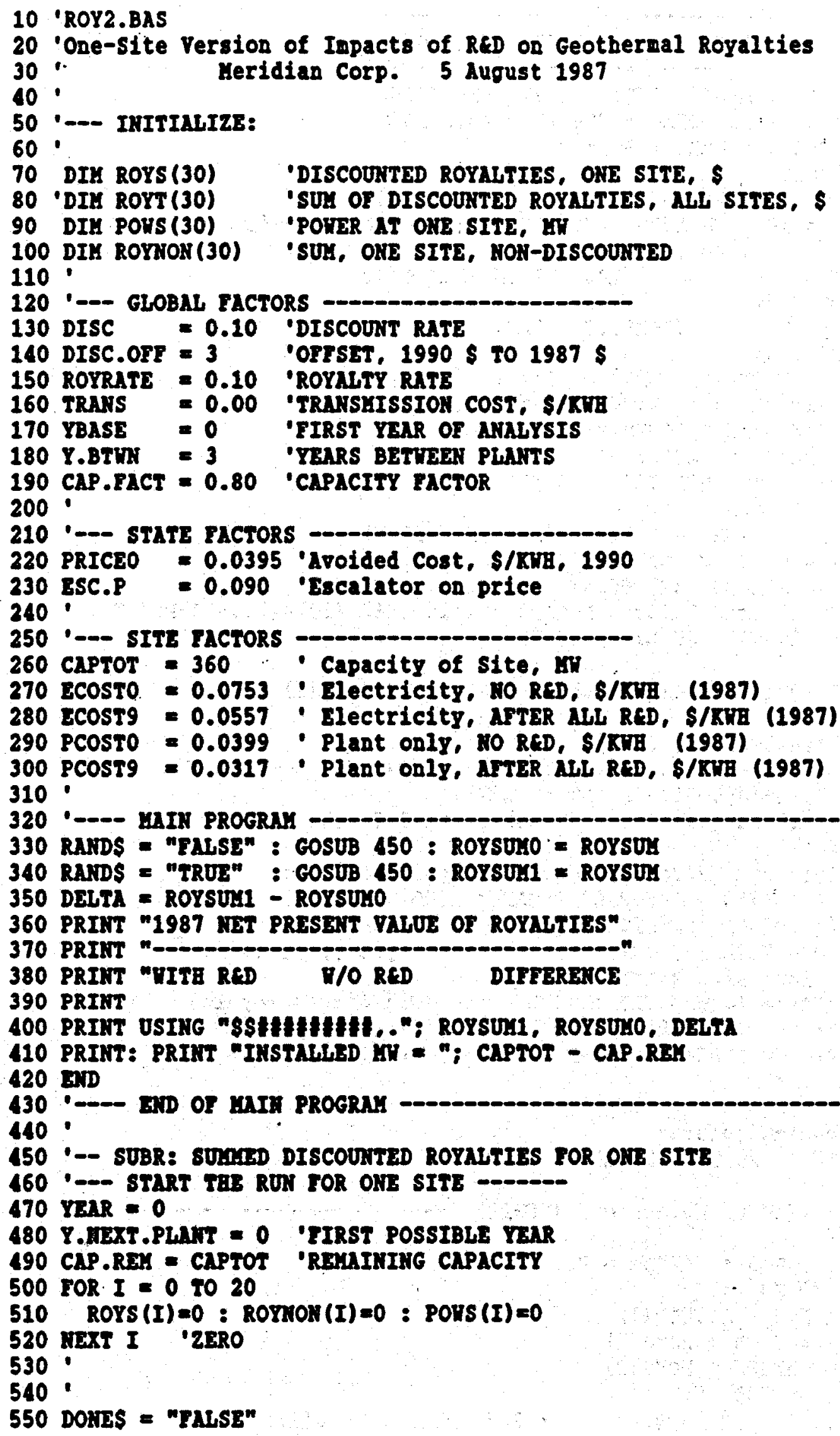




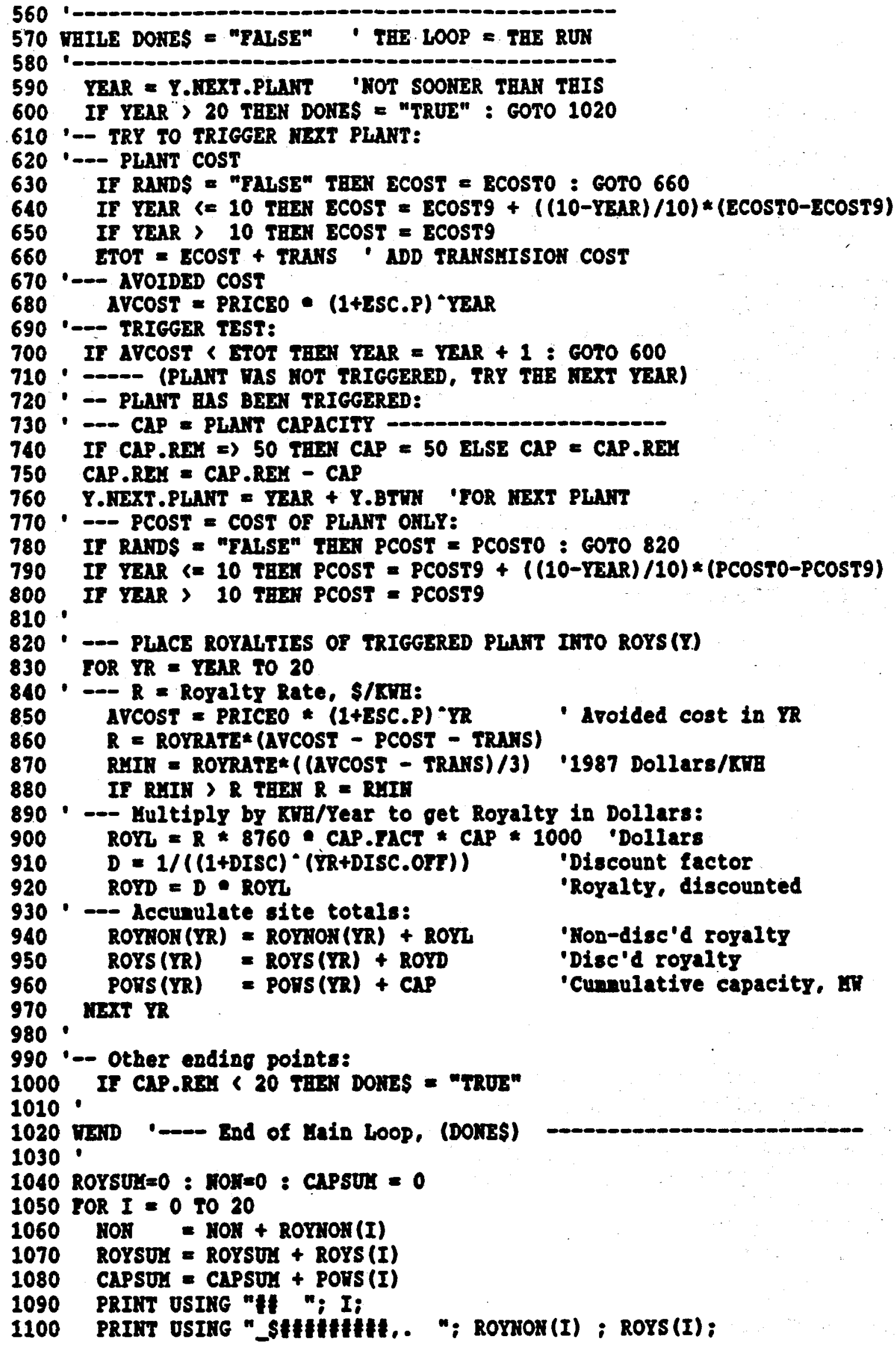


1110 PRINT USIRG "AfHE" ; PONS(I)

$1120 \mathrm{KEXT} I$

1130 PRIKT

$1140^{\circ}$

1150 RETURN

1160 -- END SUBR: Royalty at one site 
TABLED RESULTS OF ROYALTY INCOME

\begin{tabular}{|c|c|c|c|c|c|c|c|c|c|}
\hline TRANS. COSTS & EASTMYESA & BEOHAHE & LARECITY & GLASS RT. & BREI ' BUSH & MONO-LONG & STMBTSPRG & DESERTPK & RNDSBURG \\
\hline $\begin{array}{l}\text { UITH RED (DISC. 10\%) } \\
\text { W/O RED (DISC. 10\%) }\end{array}$ & $\begin{array}{l}\$ 30,706,480 \\
\$ 22,865,740\end{array}$ & $\begin{array}{l}\$ 23,863,250 \\
\$ 21,299,670\end{array}$ & $\begin{array}{r}\$ 15,310,890 \\
\$ 6,486,632\end{array}$ & $\begin{array}{l}\$ 19,149,840 \\
\$ 10,972,540\end{array}$ & $\begin{array}{l}\text { \$o } \\
\text { so }\end{array}$ & $\begin{array}{r}\$ 11,706,820 \\
\$ 5,978,024\end{array}$ & $\begin{array}{l}\$ 41,164,750 \\
\$ 36,934,740\end{array}$ & $\begin{array}{l}\$ 66,796,330 \\
\$ 66,526,560\end{array}$ & $\begin{array}{r}\$ 11,015,560 \\
\$ 7,296,091\end{array}$ \\
\hline 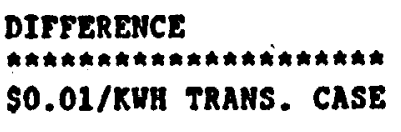 & $\$ 7,840,740$ & $\$ 2,563,580$ & $\$ 8,824,258$ & $\$ 8,177,300$ & \$o & $\$ 5,728,796$ & $\$ 4,230,010$ & $\$ 269,770$ & $\$ 3,719,469$ \\
\hline $\begin{array}{l}\text { WITH RED (DISC. 10\%) } \\
\text { W/O RED (DISC. 10\%) }\end{array}$ & $\begin{array}{l}\$ 25,102,710 \\
\$ 17,986,020\end{array}$ & $\begin{array}{l}\$ 19,675,090 \\
\$ 15,422,850\end{array}$ & $\begin{array}{r}\$ 11,934,920 \\
\$ 4,502,450\end{array}$ & $\begin{array}{r}\$ 15,059,160 \\
\$ 8,221,180\end{array}$ & $\begin{array}{l}\text { so } \\
\text { so }\end{array}$ & $\begin{array}{l}\$ 9,089,490 \\
\$ 4,370,129\end{array}$ & $\begin{array}{l}\$ 29,543,350 \\
\$ 25,931,540\end{array}$ & $\begin{array}{l}\$ 49,194,280 \\
\$ 43,851,370\end{array}$ & $\begin{array}{l}\$ 9,132,841 \\
\$ 5,807,249\end{array}$ \\
\hline DITTERENCE & $\$ 7,116,690$ & $\$ 4,252,240$ & $\$ 7,432,470$ & $\$ 6,837,980$ & so & $\$ 4,719,361$ & $\$ 3,611,810$ & $\$ 5,342,910$ & $\$ 3,325,592$ \\
\hline
\end{tabular}




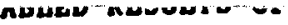

KLAMATE

UITH RED (DISC. 108)

W/O RED (DISC. 10\%)

\section{DIFPERENCE}

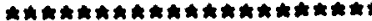

\$O.01/KUH TRANS. CASE

UITH RED (DISC. 108)

H/O RED(DISC. 10\%)

DIFERRENCE

$\begin{array}{lrrr}\text { \$o } & \$ 12,592,640 & \$ 1,924,963 & \$ 45,431,130 \\ \text { So } & \$ 4,983,395 & \$ 1,520,062 & \$ 40,650,550 \\ \text { so } & \$ 7,609,245 & \$ 404,901 & \$ 4,780,580 \\ & & & \\ & & & \\ \text { so } & \$ 9,796,593 & \$ 1,224,667 & \$ 32,704,520 \\ \$ 0 & \$ 4,662,313 & \$ 894,358 & \$ 28,639,790 \\ \text { so } & \$ 5,234,280 & \$ 330,309 & \$ 4,064,730\end{array}$

DARROUGH

GEYSERS

RYE PATCH

RYLE

$\$ 5,234,280$

$\$ 330,309$

$\$ 331,596$

$\$ 331,596$

$\$ 11,822,370$

$\$ 6,029,798$

$\$ 5,792,572$

$\$ 62,265,790$

$\$ 61,992,490$

$\$ 273,300$

$\$ 9,181,720$

$\$ 4,408,658$

$\$ 46,293,430$

$\$ 41,318,560$

$\$ 4,773,062$

$\$ 4,974,870$
$\$ 12,793,590$

$\$ 4,767,923$

$\$ 8,025,667$

$\$ 10,448,190$

$\$ 3,382,849$

$\$ 7,065,341$ 
TABLED RESULTS OF ROYALTY IMCOHE

NO TRAIIS. costs

\begin{tabular}{|c|c|c|c|c|}
\hline COVE FORT & STILLUATER & ROOSEVELT & VALE & TOTALS \\
\hline $\begin{array}{l}\$ 17,646,420 \\
\$ 13,193,800\end{array}$ & $\begin{array}{l}\$ 24,354,910 \\
\$ 11,850,070\end{array}$ & $\begin{array}{l}\$ 32,549,410 \\
\$ 29,023,450\end{array}$ & $\begin{array}{r}\$ 553,441 \\
\$ 0\end{array}$ & $\begin{array}{l}\$ 441,980,180 \\
\$ 352,371,535\end{array}$ \\
\hline$\$ 4,452,620$ & $\$ 12,504,840$ & $\$ 3,525,960$ & $\$ 553,441$ & $\$ 89,608,645$ \\
\hline $\begin{array}{l}\$ 9,421,134 \\
\$ 5,113,681\end{array}$ & $\begin{array}{r}\$ 19,174,460 \\
\$ 8,726,629\end{array}$ & $\begin{array}{l}\$ 16,697,100 \\
\$ 12,736,480\end{array}$ & $\begin{array}{r}\$ 304,872 \\
\$ 0\end{array}$ & $\begin{array}{l}\$ 323,978,527 \\
\$ 236,276,106\end{array}$ \\
\hline$\$ 4,007,453$ & $\$ 10,947,831$ & $\$ 3,960,620$ & $\$ 304,872$ & $\$ 87,702,421$ \\
\hline
\end{tabular}

\begin{tabular}{lrr} 
& \multicolumn{1}{c}{ TOTALS } & \multicolumn{1}{c}{ 50\% OF TOTAL } \\
BASE CASE & $\$ 89,608,645$ & $\$ 44,804,323$ \\
TRANS. CASE & $\$ 87,702,421$ & $\$ 43,851,211$
\end{tabular}

$\grave{n}$ 


\section{APPENDIX 6}

KGRA ROYALTY RESULTS

G-1/e -1 


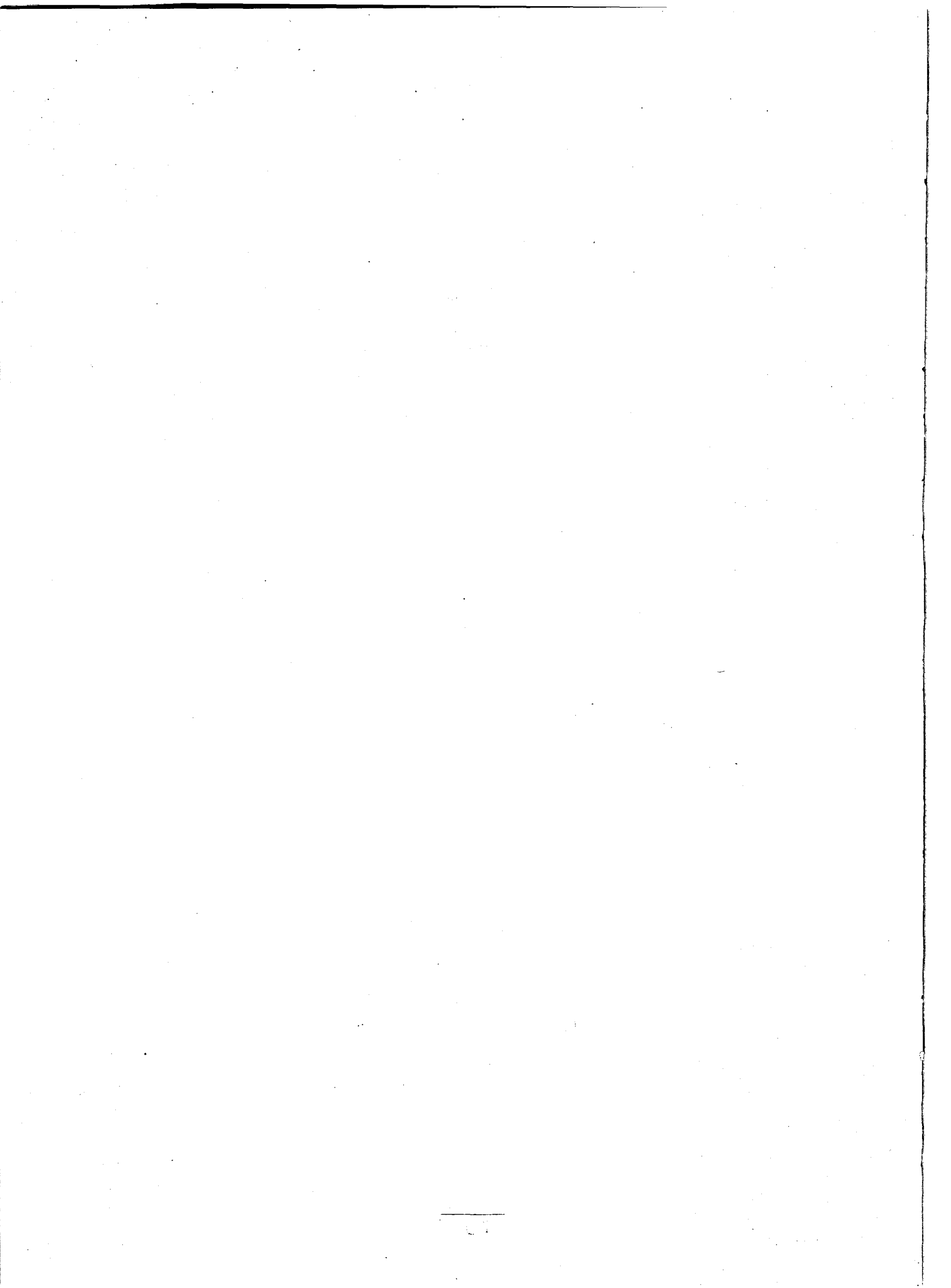




\section{KGRA ROYALTY RESULTS}

(Detailed Version) 

This Appendix contains the results of the royalties program runs. Each run is presented on a separate sheet. The first information is the projected nondiscounted (left column) and discounted (right column) royalty income without R\&D benefits for years $0-20$ (corresponding to 1990-2010). This is followed by the results incorporating R\&D benefits. 



\section{RESULTS ASSUMING NO TRANSMISSION COSTS}

$$
\text { G-7/G-8 }
$$




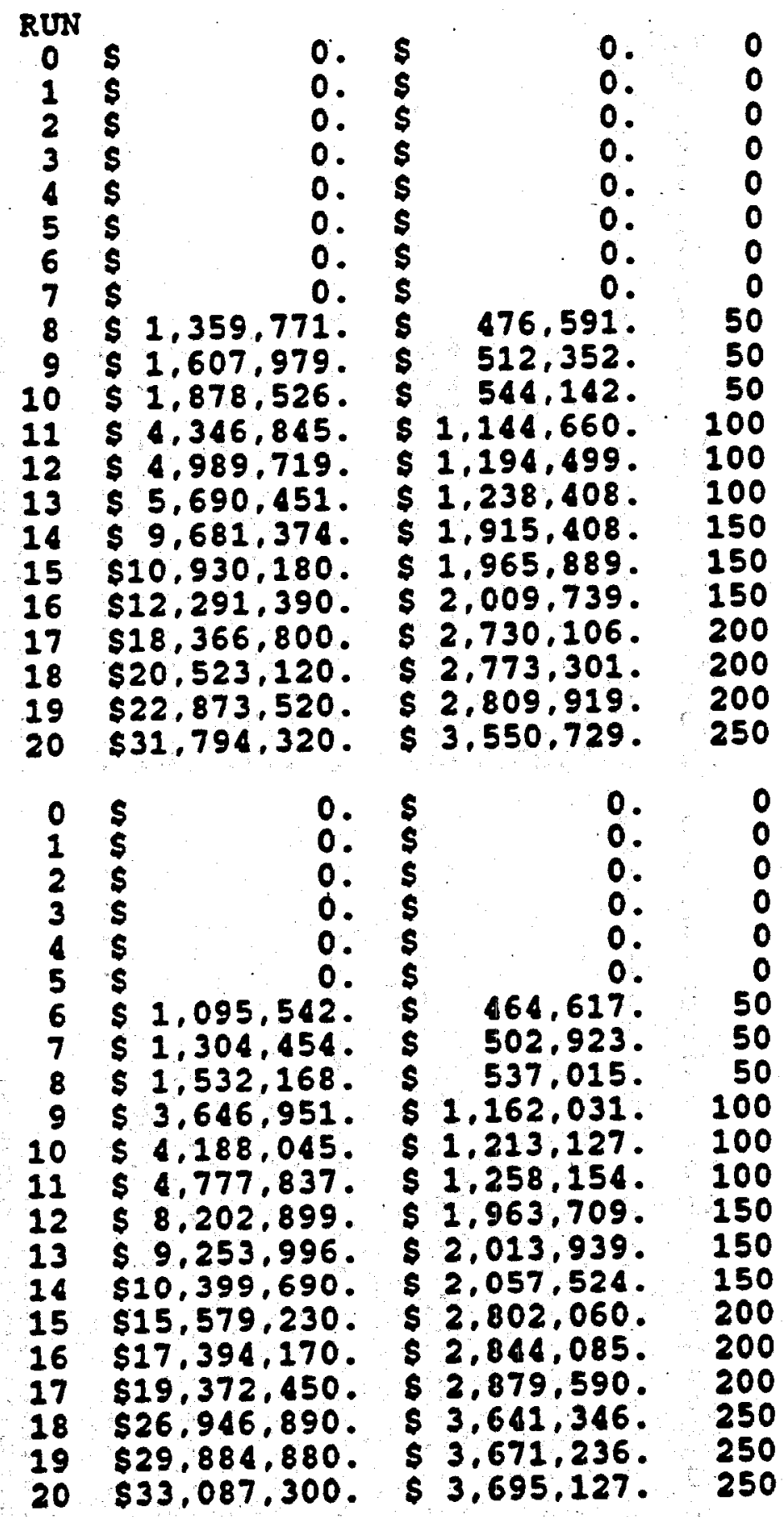

1987 NET PRESENT VALUE OF ROYALTIES

HITH RED H/O RED DIFFERENCE

$\$ 30,706,480, \$ 22,865,740 . \$ 7,840,740$.

INSTALLED MH $=250$

OK 


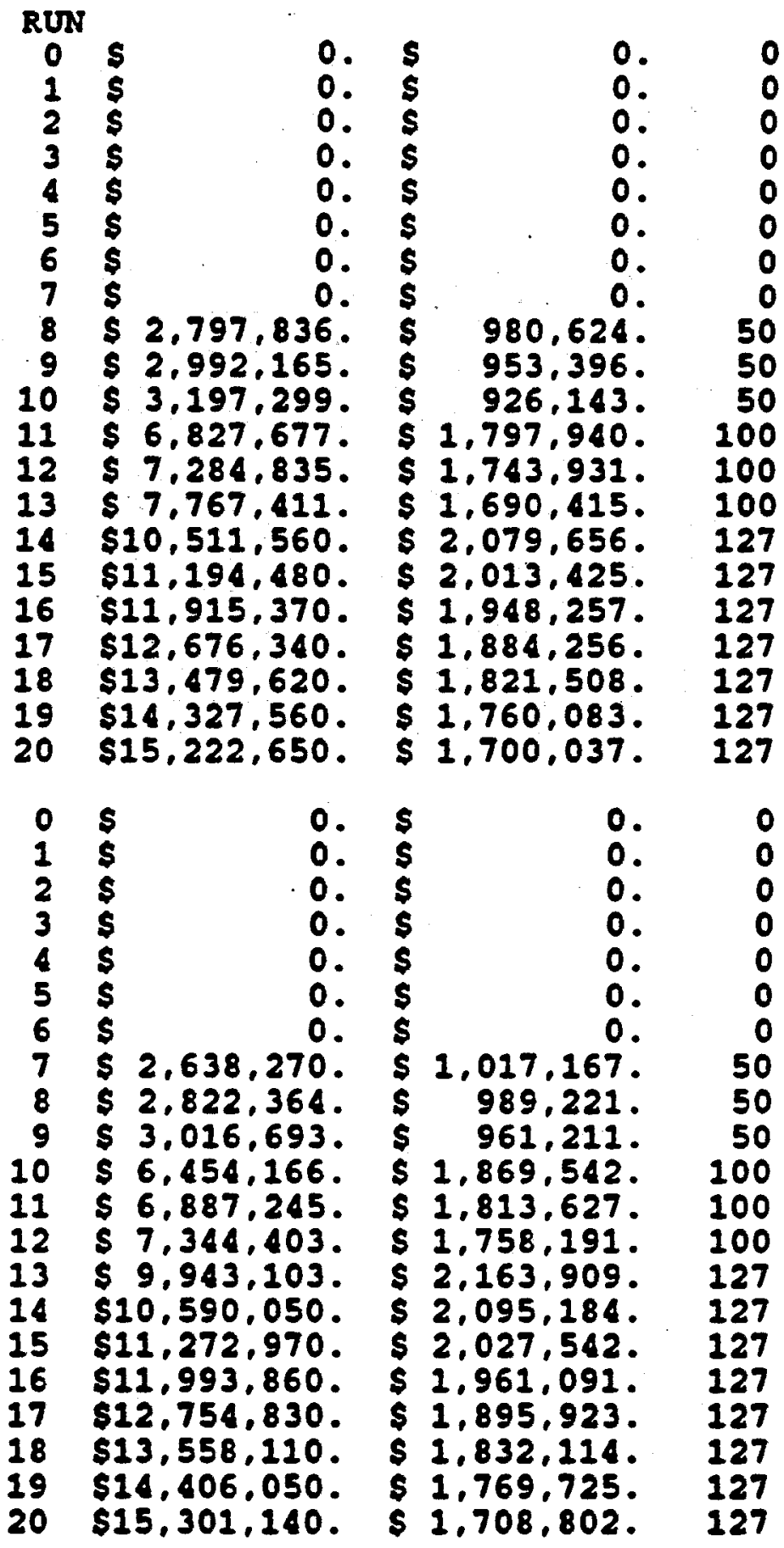

1987 NET PRESENT VALUE OE ROYALTIES WITH RED H/O RED DIFFERENCE $\$ 23,863,250 . \$ 21,299,670 . \$ 2,563,580$. INSTALLED MN $=127$ Ok 


\begin{tabular}{|c|c|c|c|c|}
\hline $\begin{array}{l}0 \\
1 \\
2 \\
3 \\
4 \\
5 \\
6 \\
7 \\
8 \\
9 \\
10 \\
11 \\
12 \\
13 \\
14 \\
15 \\
16 \\
17 \\
18 \\
19\end{array}$ & 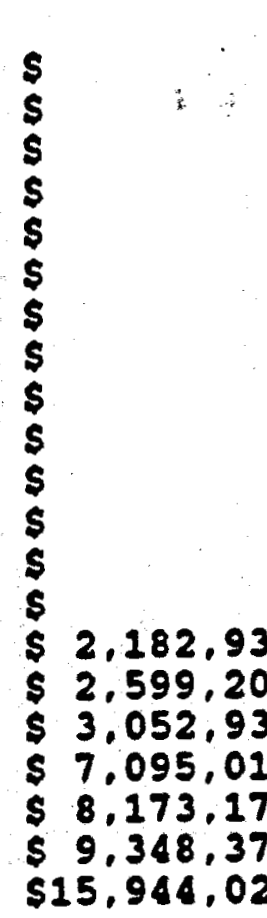 & $\begin{array}{l}0 . \\
0 . \\
0 . \\
0 . \\
0 . \\
0 . \\
0 . \\
0 . \\
0 . \\
0 . \\
0 . \\
0 . \\
0 . \\
0 . \\
32 . \\
03 . \\
37 . \\
15 .\end{array}$ & 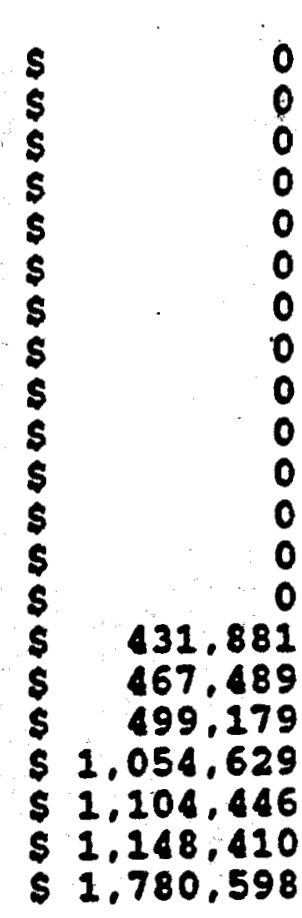 & $\begin{array}{l}0 . \\
0 . \\
0 . \\
0 .\end{array}$ \\
\hline $\begin{array}{l}0 \\
1 \\
2 \\
3 \\
4 \\
5 \\
6 \\
7 \\
8 \\
9 \\
10 \\
11 \\
12 \\
13 \\
14 \\
15 \\
16 \\
17 \\
18 \\
19 \\
20\end{array}$ & $\begin{array}{l}\$ \\
\$ \\
\$ \\
\$ \\
\$ \\
\$ \\
\$ \\
\$ \\
\$ \\
\$ \\
\$ 1,405,48 \\
\$ 1,700,38 \\
\$ 2,021,82 \\
\$ 4,744,37 \\
\$ 5,508,17 \\
\$ 6,340,71 \\
\$ 10,872,27 \\
\$ 12,355,98 \\
\$ 13,973,22 \\
\$ 20,981,37 \\
\$ 23,543,30\end{array}$ & $\begin{array}{l}0 . \\
0 . \\
0 . \\
0 . \\
0 . \\
0 . \\
0 . \\
0 . \\
0 . \\
0 . \\
87 . \\
83 . \\
20 . \\
71 . \\
70 . \\
10 .\end{array}$ & 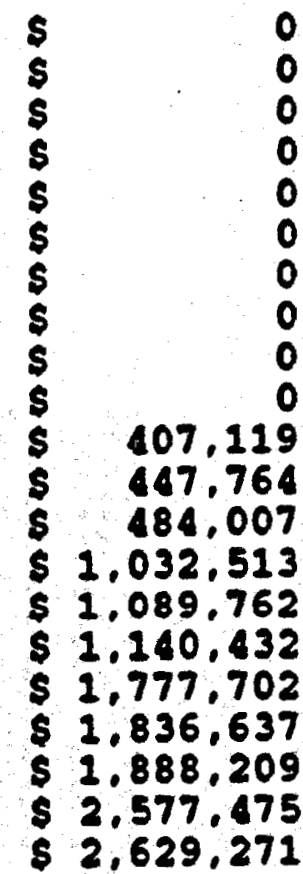 & \\
\hline
\end{tabular}

1987 NET PRESENT VALUE OF ROYALTIES

WITH RED W/O RED DIFEERENCE

$\$ 25,310,890, \$ 6,486,632$. \$8,824,260.

INSTALLED MW $=200$

Ok 


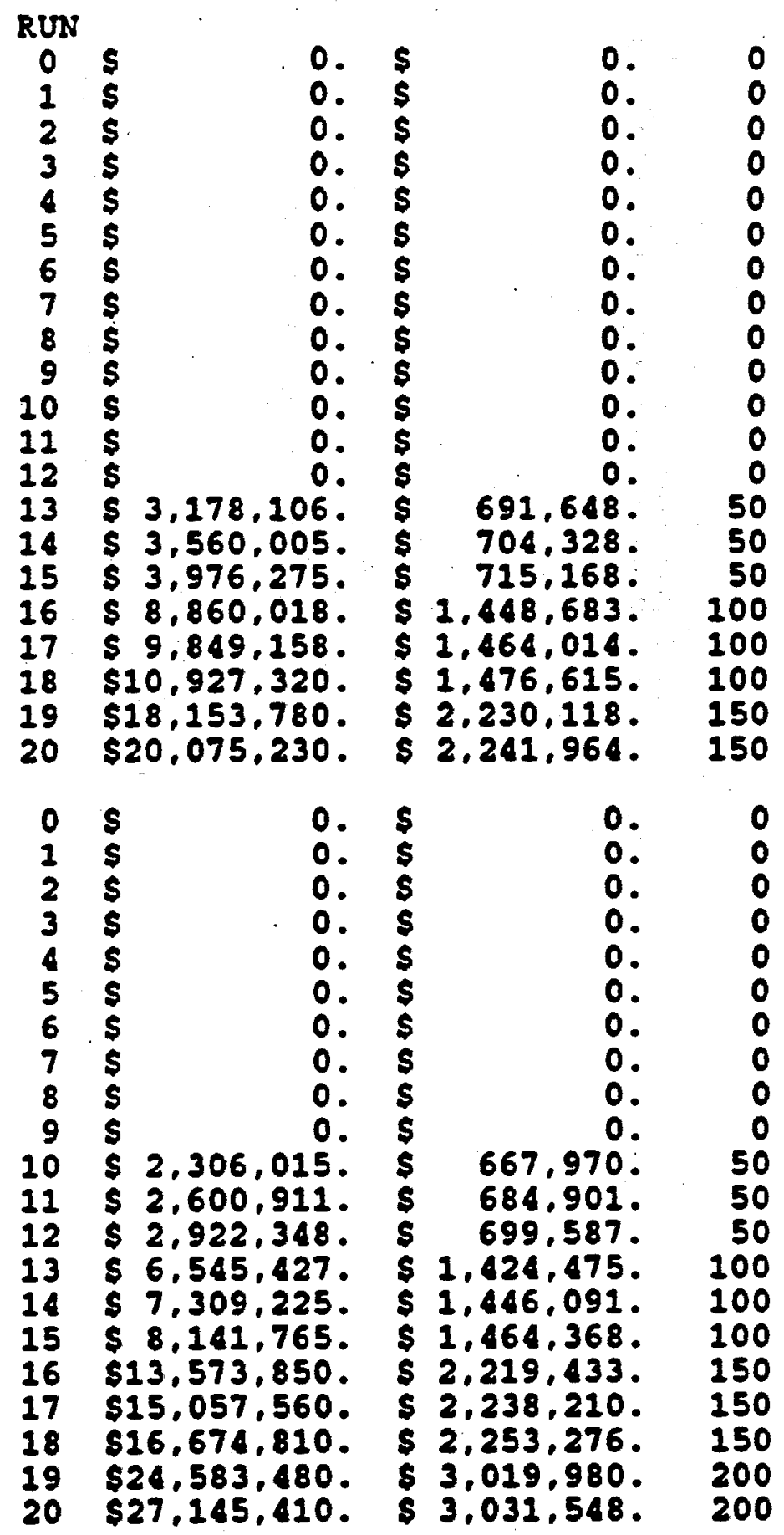

1987 NET PRESENT VALUE OF ROYALTIES NITH RED W/O RED DIFEERENCE $\$ 19,149,840 . \$ 10,972,540 . \$ 8,177,300$. INSTALLED MN $=200$ Ok 


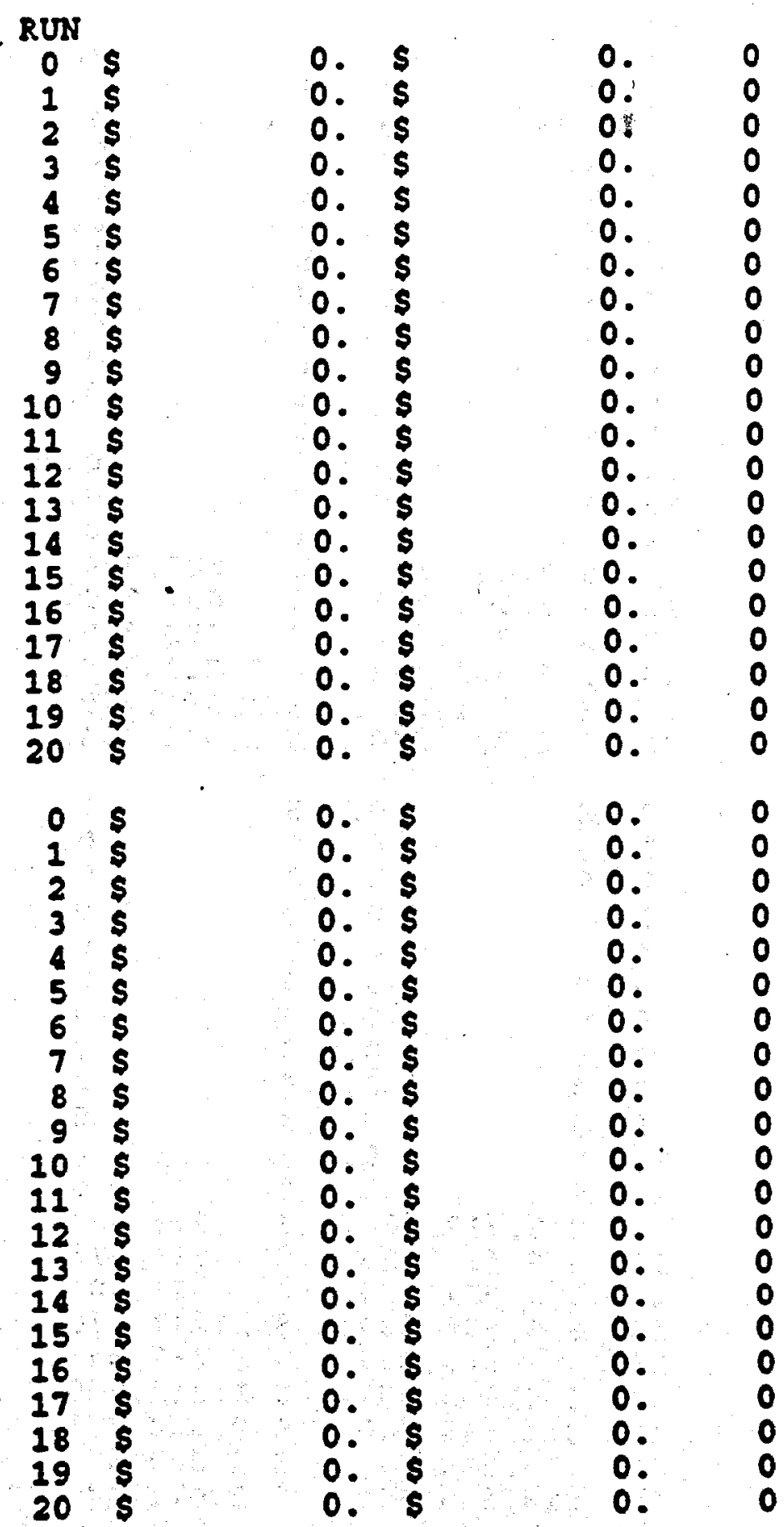

1987 NET PRESENT VALUE OF ROYALTIES WITH RED W/O RED DIFFERENCE so. so. so.

INSTALLED MW = 0 Ok 


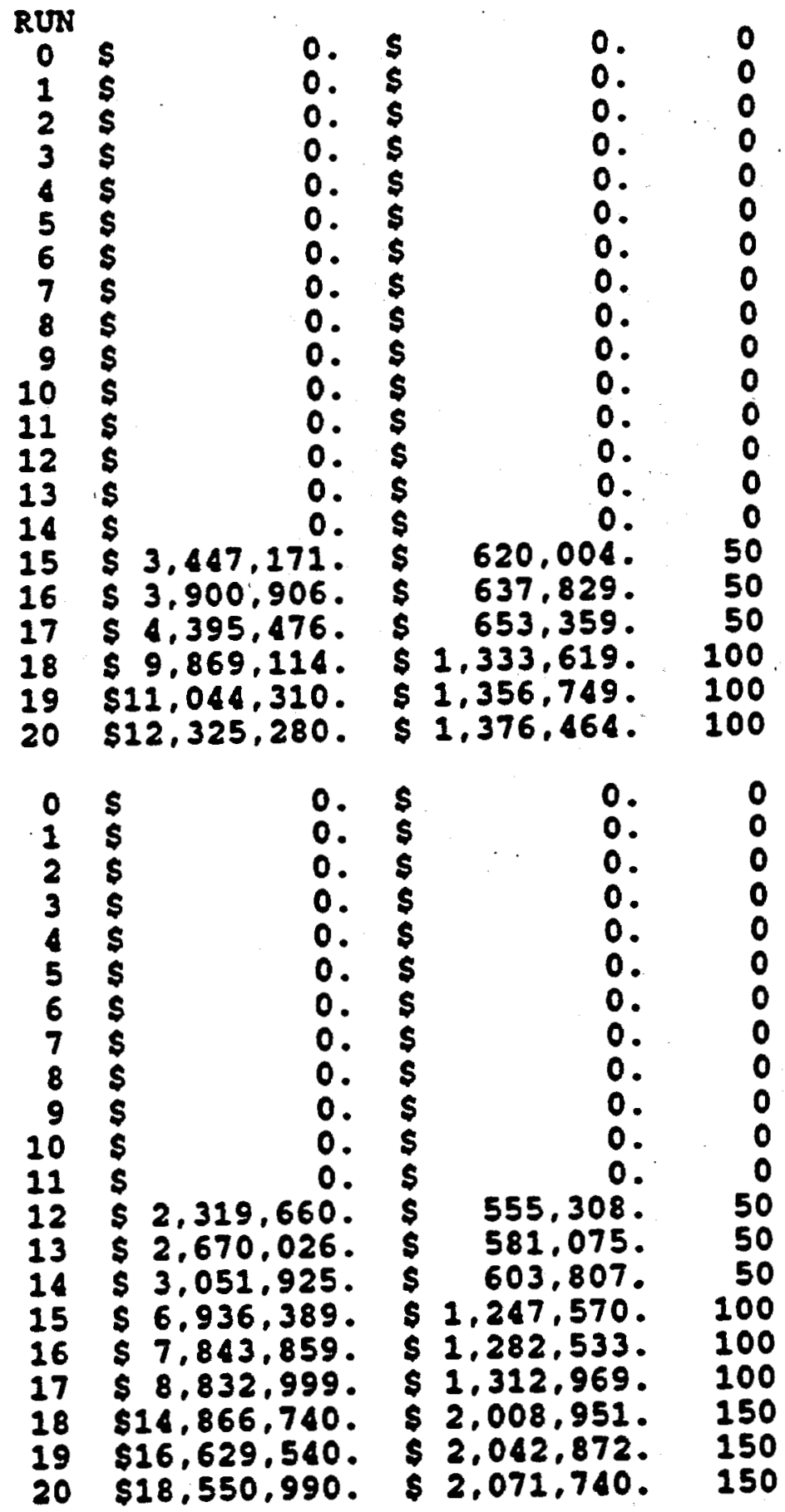

1987 NET PRESENT VALUE OF ROYALTIES

WITH RED W/O RED DIFEERENCE
$\$ 11,706,820 . \$ 5,978,024 . \$ 5,728,801$.
INSTALLED MW $=150$
OK




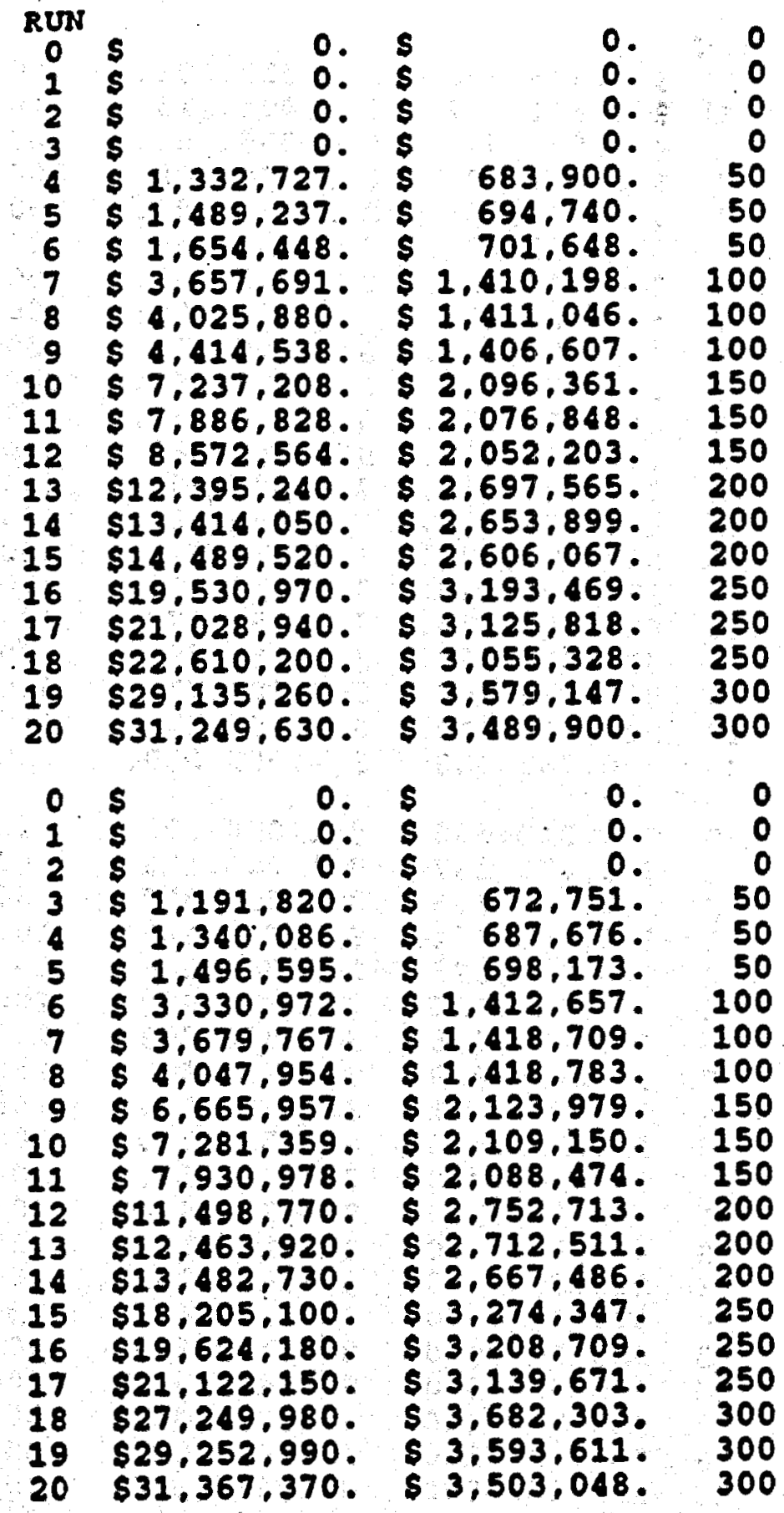

1987 NET PRESENT VALUE OF ROYALTIES

WITH RED W/O RED DIFFERENCE

$\$ 41,164,750, \$ 36,934,740, \$ 4,230,012$.

INSTALLED MW $=300$ OK 


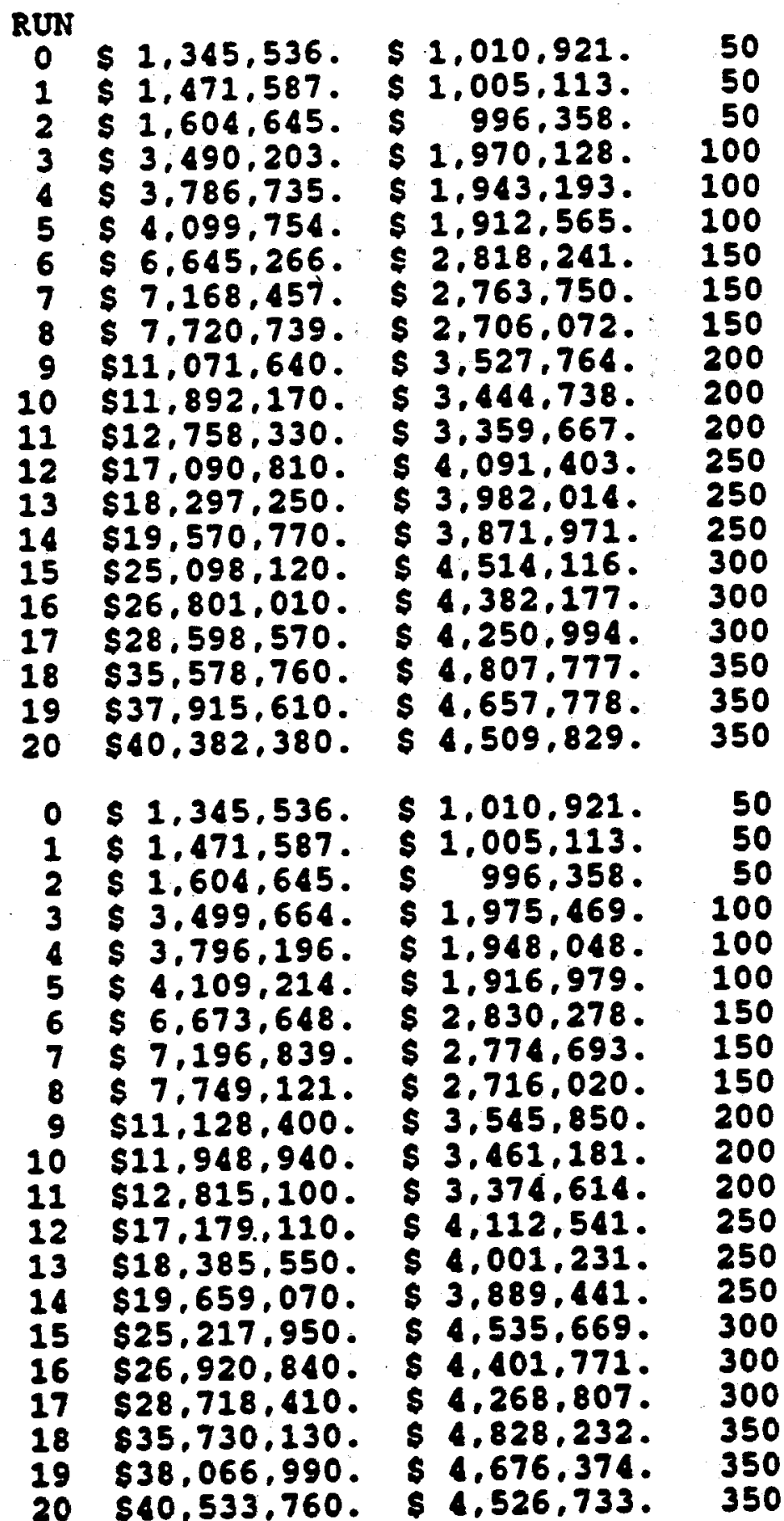

1987 NET PRESENT VALUE OE ROYALTIES

WITH RED W/O RED DIFEERENCE

\footnotetext{
$\$ 66,796,330 . \$ 66,526,560 . \$ \$ 269,764$

INSTALLED MH $=350$ Ok
} 


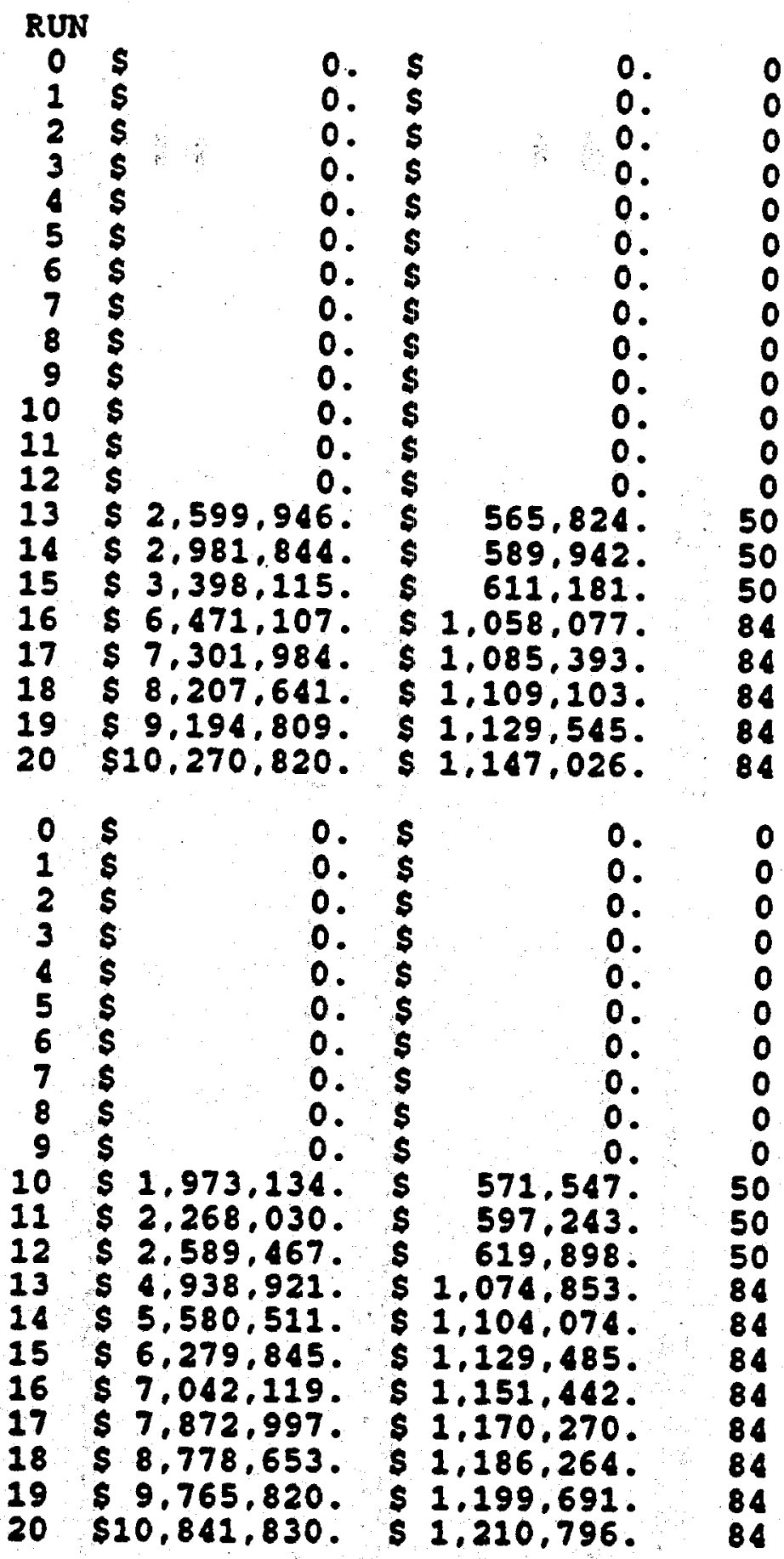

1987 NET PRESENT VALUE OF ROYALTIES

WITH RED W/O RED DIFFERENCE

$\$ 11,015,560 . \$ 7,296,091 . \$ 3,719,472$.

INSTALLED MN $=84$ Ok 


$\begin{array}{cc}\text { RUN } & \\ 0 & \$ \\ 1 & \$ \\ 2 & \$ \\ 3 & \$ \\ 4 & \$ \\ 5 & \$ \\ 6 & \$ \\ 7 & \$ \\ 8 & \$ \\ 9 & \$ \\ 10 & \$ \\ 11 & \$ \\ 12 & \$ \\ 13 & \$ \\ 14 & \$ \\ 15 & \$ \\ 16 & \$ \\ 17 & \$ \\ 18 & \$ \\ 19 & \$ \\ 20 & \$\end{array}$

o. $s$

$0 . \quad 0$

0. $\$$

0. $\$$

0. s

o. $\$$

o. $\$$

0. 5

0. $\$$

0. \$

0. \$

0. \$

0.5

o. 5

0. 5

0. S

o. s

o. 5

o. S

0.5

0. $\$$

o. $\$$

0. 0

o. 5

0.5

$0 . \$$

$0 . \quad \$$

0. $\$$

0. $\$$

o. $\$$

0. 5

o. 5

o. 5

0. 5

0. $\$$

0. $\$$

o. 5

o. 5

$0 . \quad 0$

$0 . \quad 0$

$0 . \quad 0$

$0 . \quad 0$

$0 . \quad 0$

0. 0

0

$0 . \quad 0$

$0 . \quad 0$

$0 . \quad 0$

0 . 0

$0 . \quad 0$

0.0

o. 0

$0 . \quad 0$

$\begin{array}{ll}0 . & 0 \\ 0 . & 0\end{array}$

o. 5

o. 0

o. 0

$0 . \quad 0$

$0 . \quad 0$

$0 . \quad 0$

$0 . \quad 0$

$0 . \quad 0$

$0 . \quad 0$

$0 . \quad 0$

$0 . \quad 0$

$0 . \quad 0$

$0 . \quad 0$

$0 . \quad 0$

$0 . \quad 0$

$0 . \quad 0$

$0 . \quad 0$

$0.5 \quad 0.00$

0. $\$$ o. 0

0. $\$$ o. 0

$\begin{array}{llll}0 . & 5 & 0 . & 0 \\ 0 . & \$ & 0 . & 0\end{array}$

$\begin{array}{ll}19 & 5 \\ 20 & 5\end{array}$

1987 NET PRESENT VALUE OF ROYALTIES WITH RED H/O RED DIFFERENCE \$o. so. \$0.

INSTALLED MN $=0$ Ok 
COSO, CA

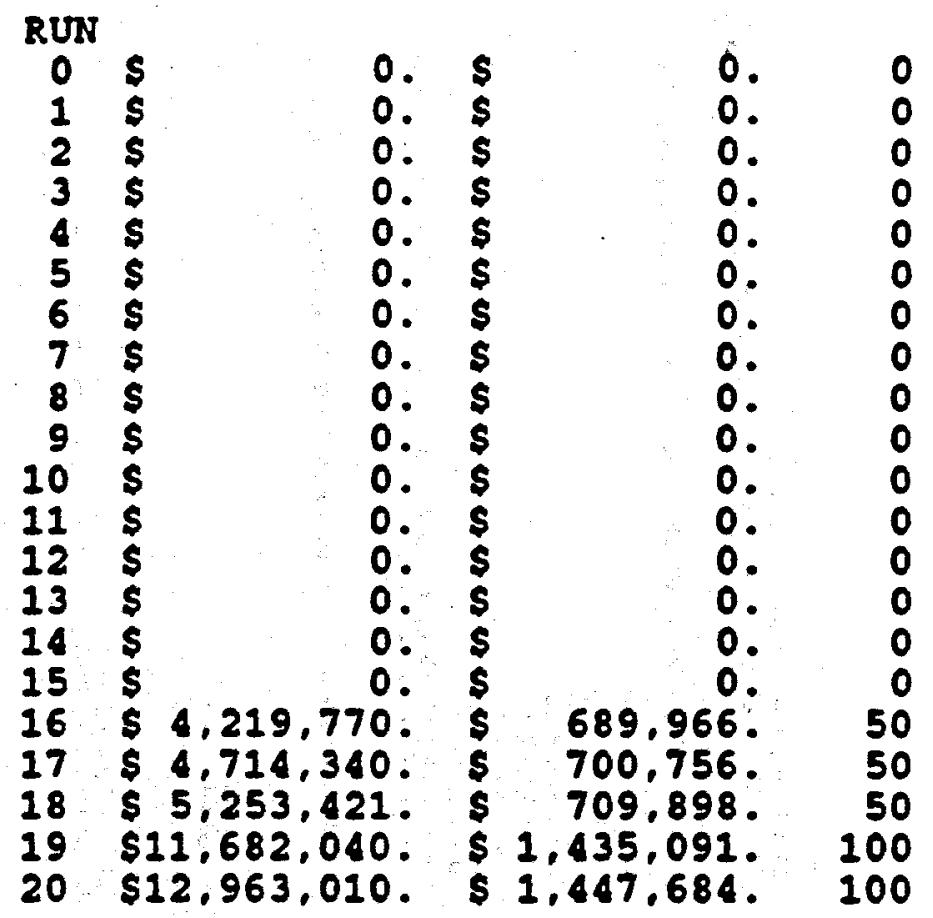

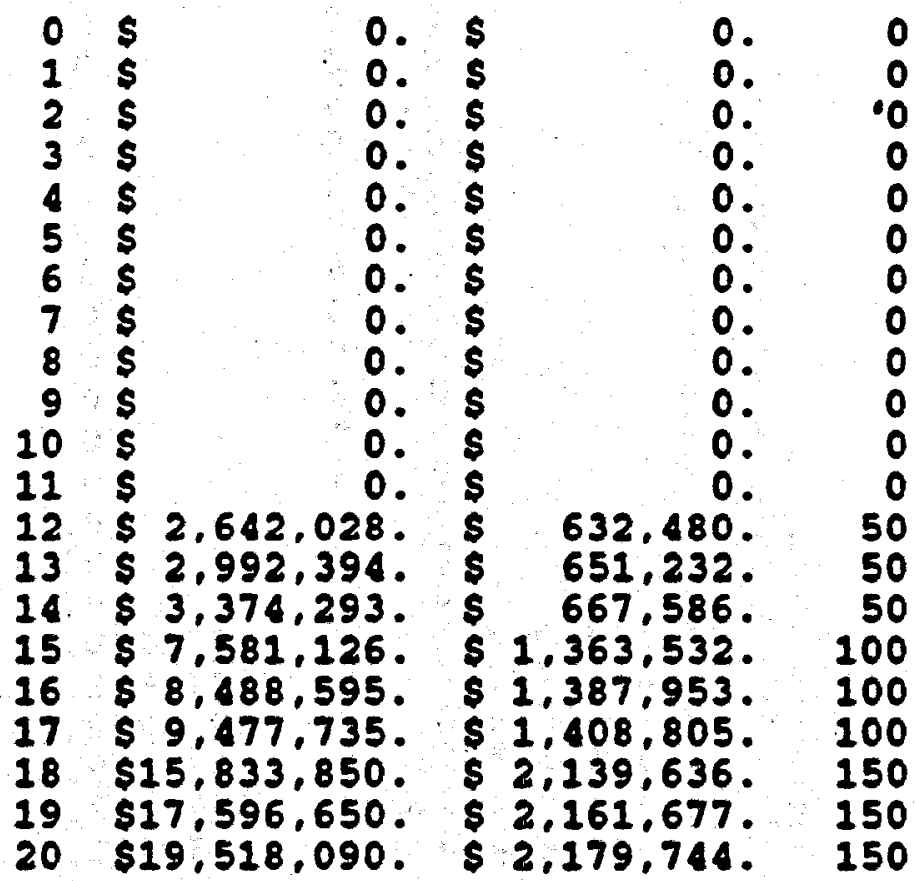

1987 NET PRESENT VALUE OF ROYALTIES WITH RED W/O RED DIFFERENCE $\$ 12,592,640, \$ 4,983,395$ \& $\$ 7,609,247$. INSTALLED MH $=150$ Ok 
NEWBERRY CALDERA, OR

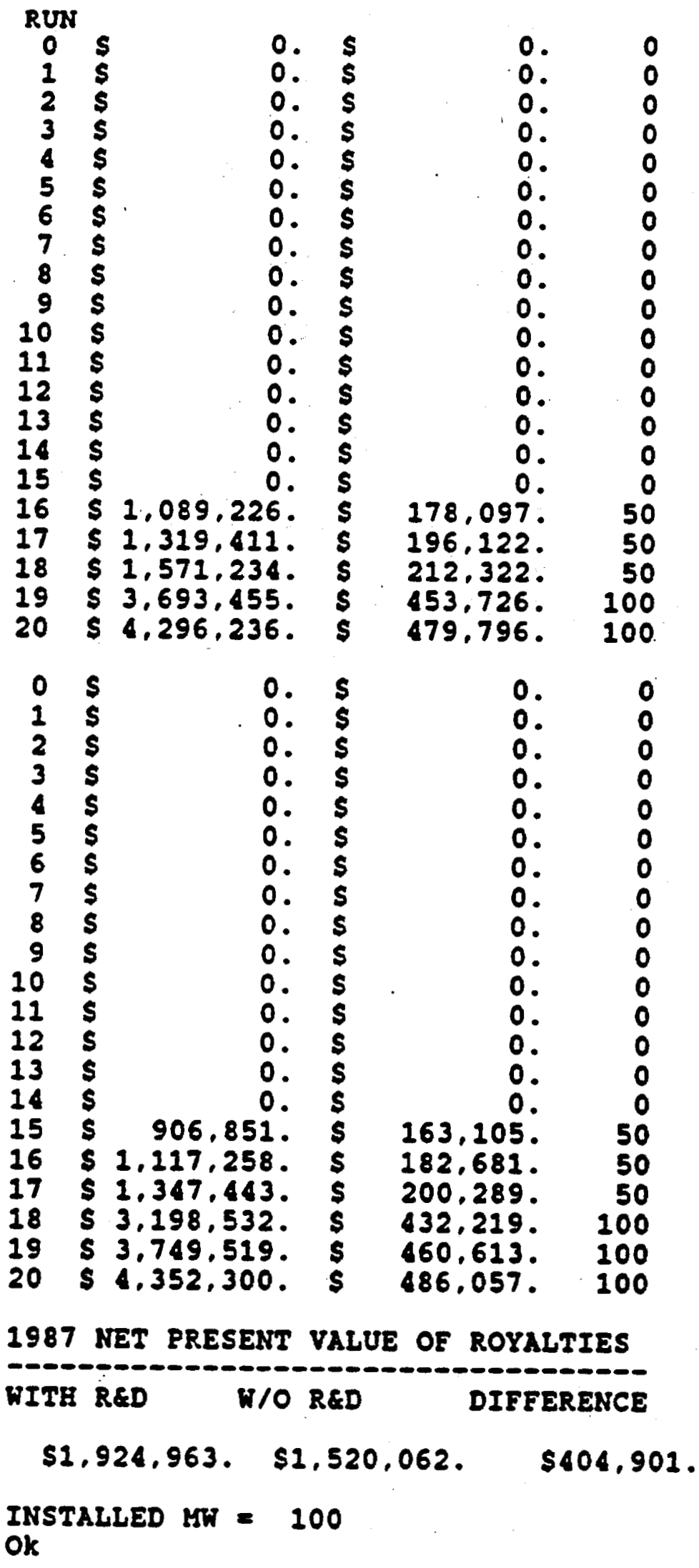


RUN

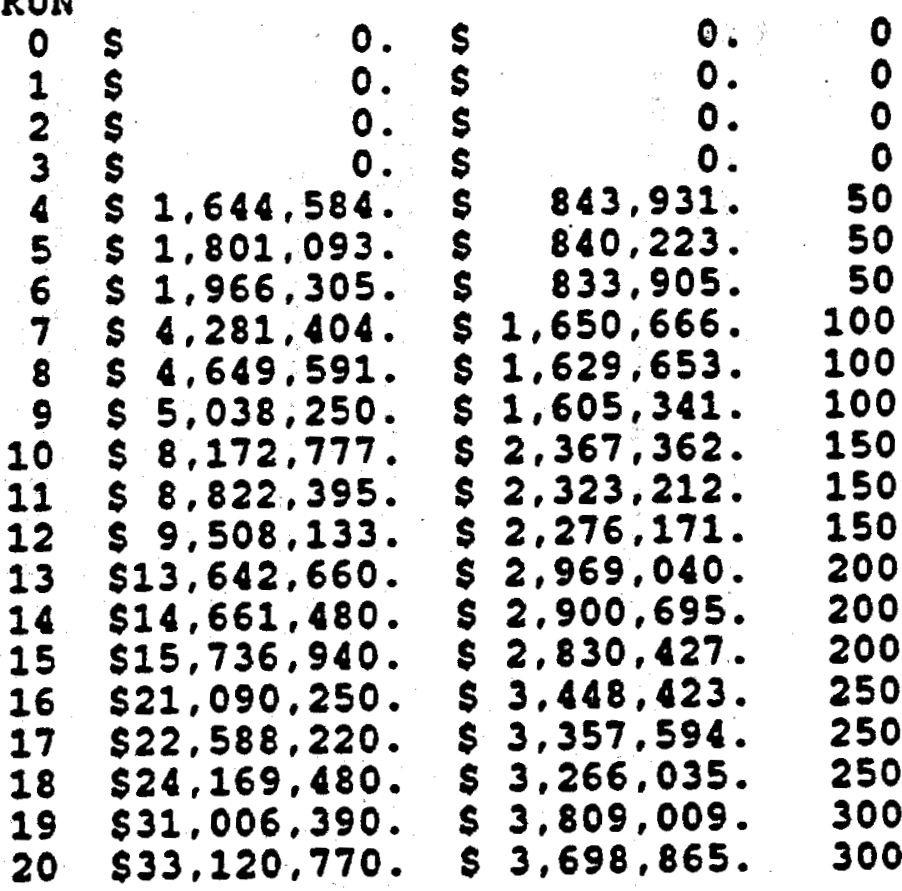

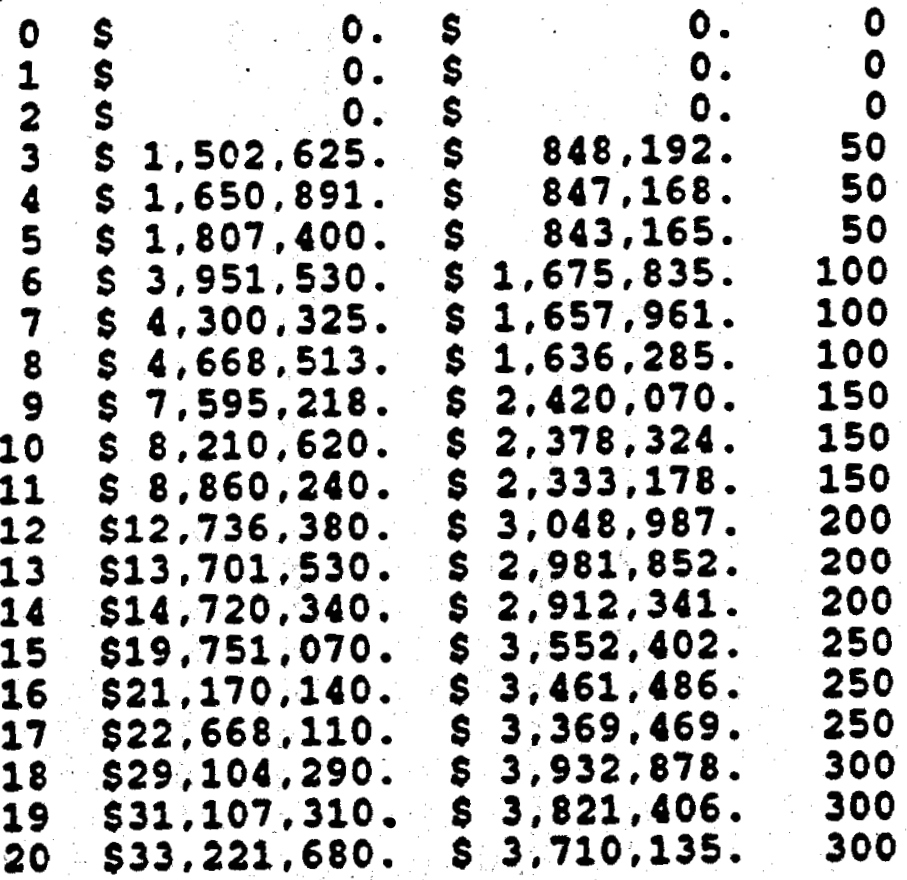

1987 NET PRESENT VALUE OF ROYALTIES

HITH RED W/O RED DIFEERENCE

$\$ 45,431,130, \$ 40,650,550, \$ 4,780,584$.

INSTALLED MN $=300$ ok 
DARROUGH HOT SPRINGS: WARM SPRINGS, NV

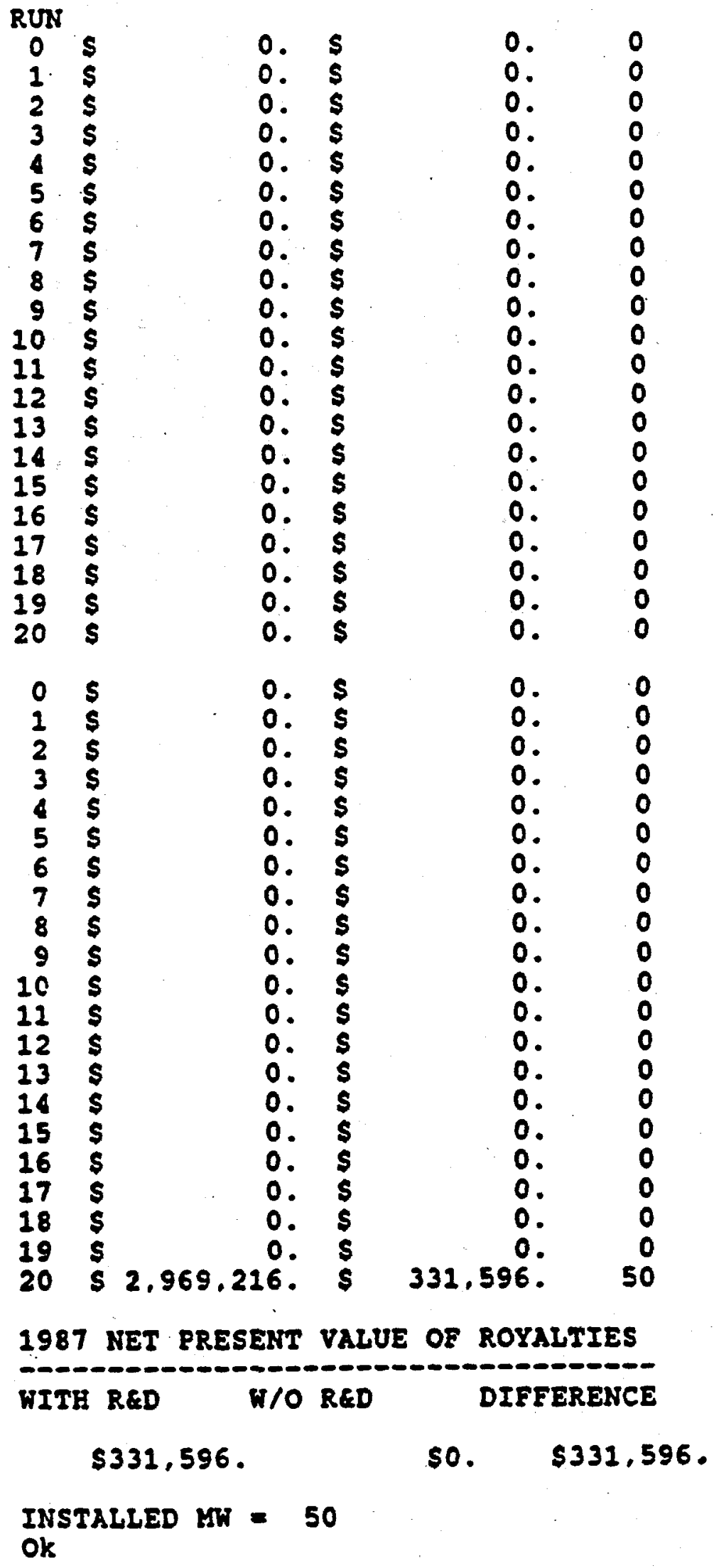


RUN

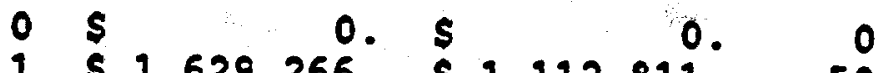

$1 \$ 1,629,266 . \$ 1.112,811 . \quad 50$

$2 \$ 1,762,325 . \quad \$ 1.094,265 . \quad 50$

$3 \$ 1,902,781$. \$ $1,074,070 . \quad 50$

$4 \$ 4,102,094 . \$ 2,105,023, \quad 100$

$5 \$ 4.415,114 . \$ 2,059,683 . \quad 100$

$6 \$ 4.745,536$. \$ 2.012,570. 100

$7 \$ 7,641,497 . \quad 52,946,127.150$

8 \$ $8,193,779$. S $2,871,869 . \quad 150$

9 s $8,776,766$. S $2,796,548,150$

$10 \quad \$ 12,522,890$. \$ $3,627,435 . \quad 200$

$11 \$ 13,389.050$. \$ $3.525,755 . \quad 200$

$12 \$ 14.303 .370 . \$ 3.424 .111 . \quad 200$

$13 \$ 19,085,650 . \$ 4.153 .593 . \quad 250$

$14 \$ 20.359 .170$. \$ 4.027 .952 . 250

$15 \$ 21,703,500$. \$ $3,903,564 . \quad 250$

$16 \$ 27,747,090$. \$ $4.536,869.300$

$17 \$ 29,544,650 . \$ 4,391,623 . \quad 300$

$18 \$ 31.442 .160$. \$ $4.248,796 . \quad 300$

$19 \$ 33,445,180 . \$ 4,108,604 . \quad 300$

$20 \$ 35,559,550, \$ 3,971,224.300$

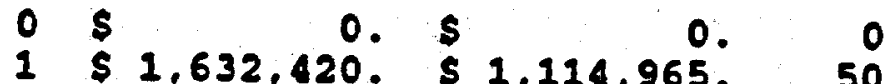

$2 \$ 1,765,478$. \$ $1,096,223 . \quad 50$

$3 \$ 1,905,935, \$ 1.075,851.50$

4 \$ $4.117,863$. \$ $2,113,114$. 100

$5 \$ 4.430,882, \$ 2,067,039 . \quad 100$

$6 \$ 4.761,305, \$ 2,019,258, \quad 100$

$7 \$ 7,679,340 \ldots \$ 2,960,718 \ldots 150$

$8 \$ 8,231,622, \$ 2,885,133, \quad 150$

$9 \$ 8,814,610, \$ 2,808,606, \quad 150$

$10 \quad \$ 12,592,270 . \quad \$ 3,647,532 . \quad 200$

$11 \$ 13,458,430 . \quad \$ 3,544,024.200$

$12 \$ 14,372,750 . \quad \$ 3,440,721.200$

$13 \$ 19,186,560, \quad \$ 4.175,554 . \quad 250$

$14 \$ 20,460,080$. \$ $4.047,917.250$

$15 \$ 21.804,410, \$ 3,921,714.250$

$16 \$ 27,879,540, \$ 4.558,525, \quad 300$

$17 \$ 29.677 .100$. $\$ .411 .311 . \quad 300$

$18 \$ 31.574 .610 . \quad \$ 4.266,694 . \quad 300$

$19 \$ 33.577 .630 . \quad \$ 4.124,874 . \quad 300$

$20 \$ 35.692,010 \ldots \$ 3,986,016 \ldots 300$

1987 NET PRESENT VALUE OF ROYALTIES

WITH RED W/O RED DIFEERENCE

$\$ 62,265,790, \$ 61,992,490, \$ \$ 273,300$.

INSTALLED MH $=300$ Ok 


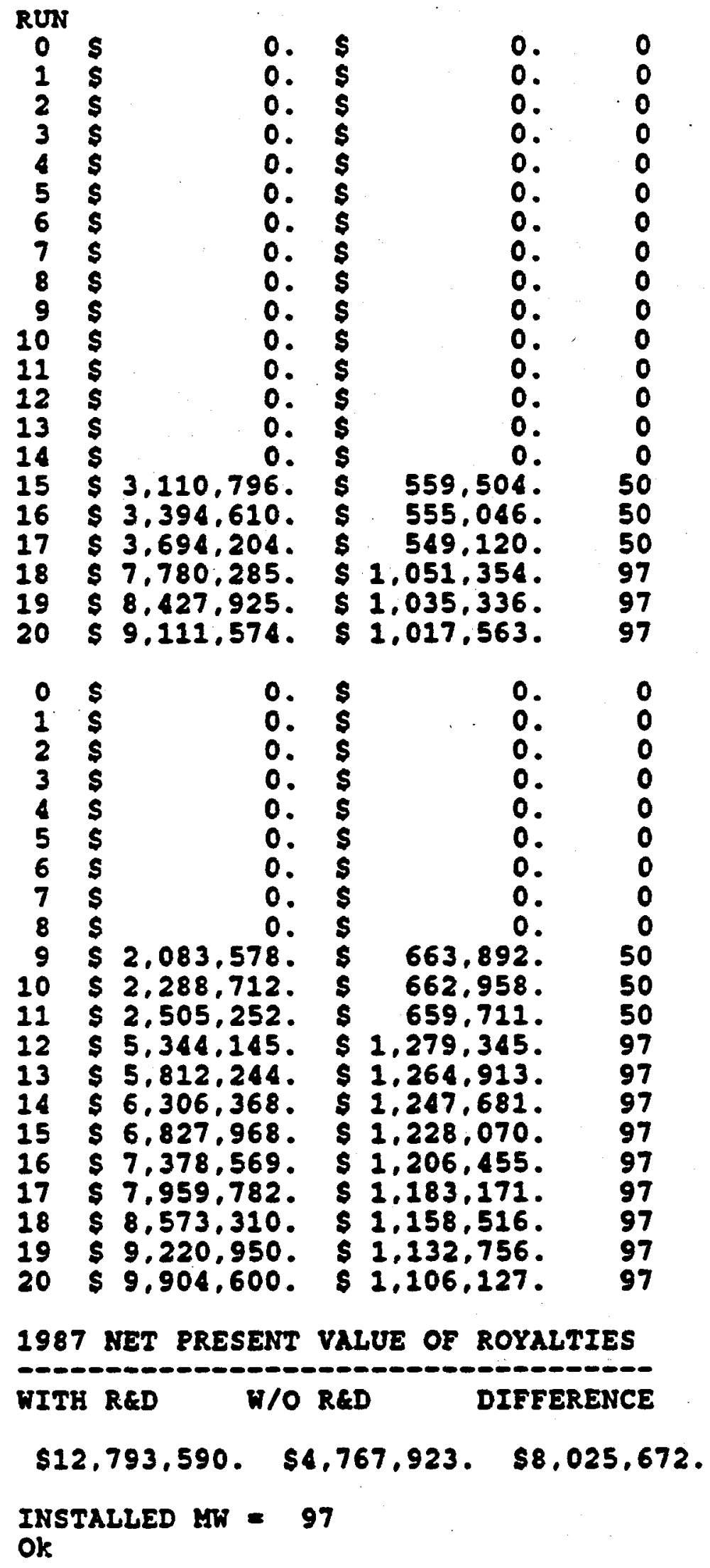




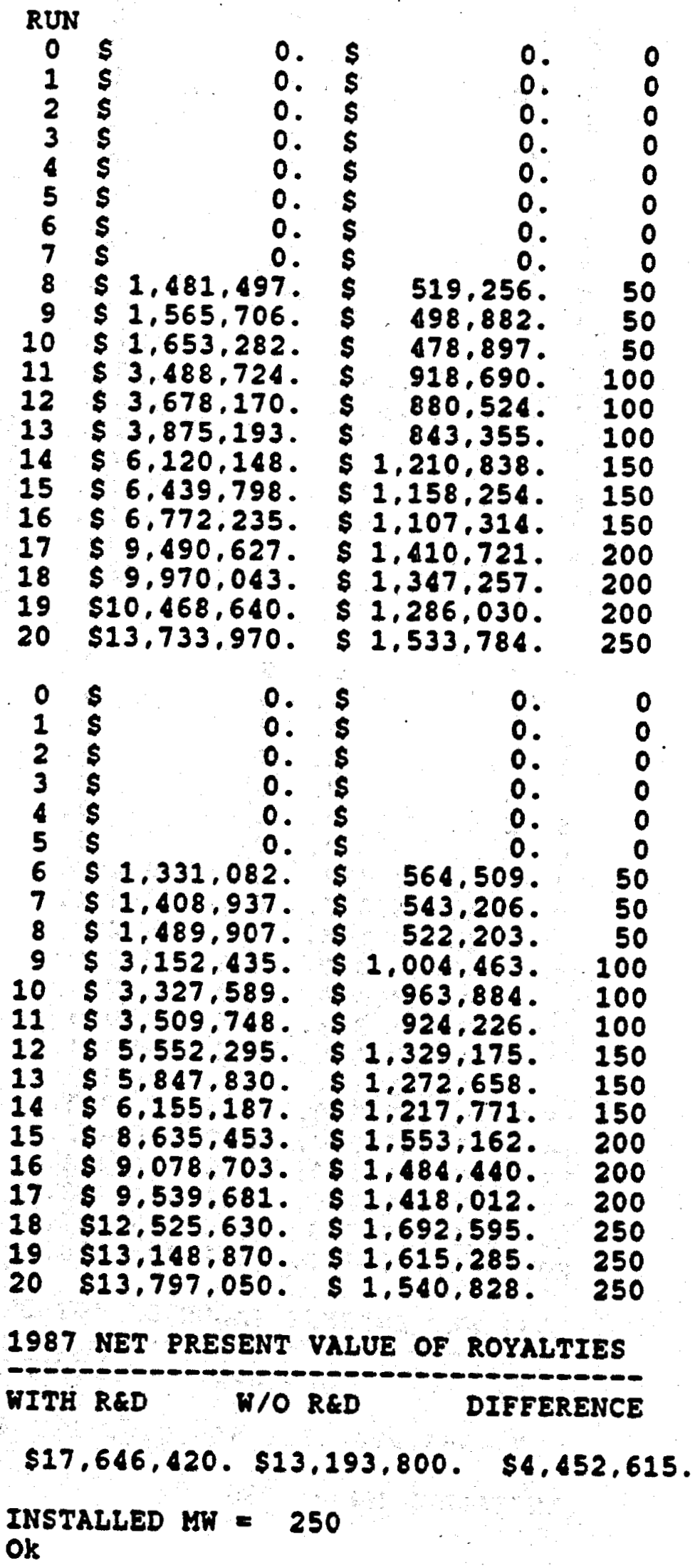




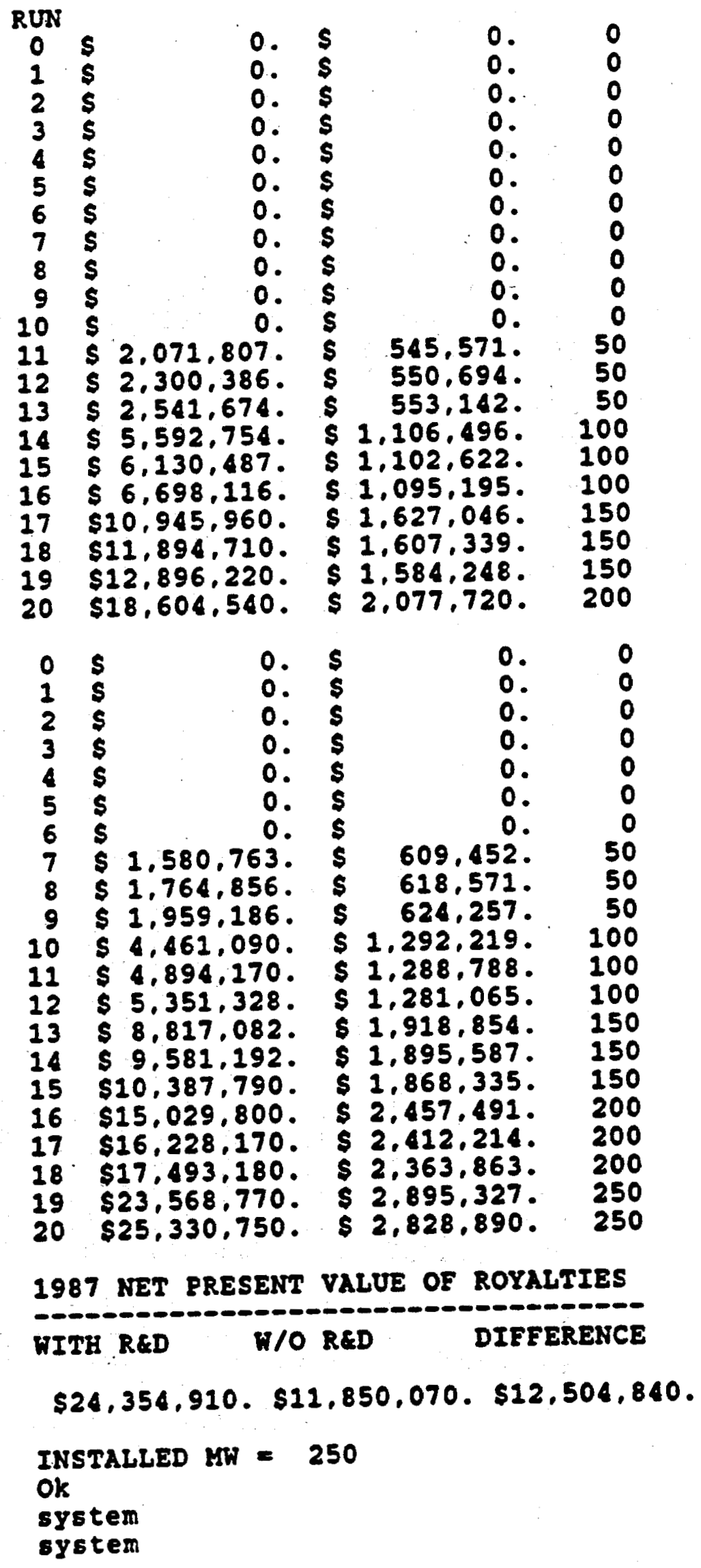




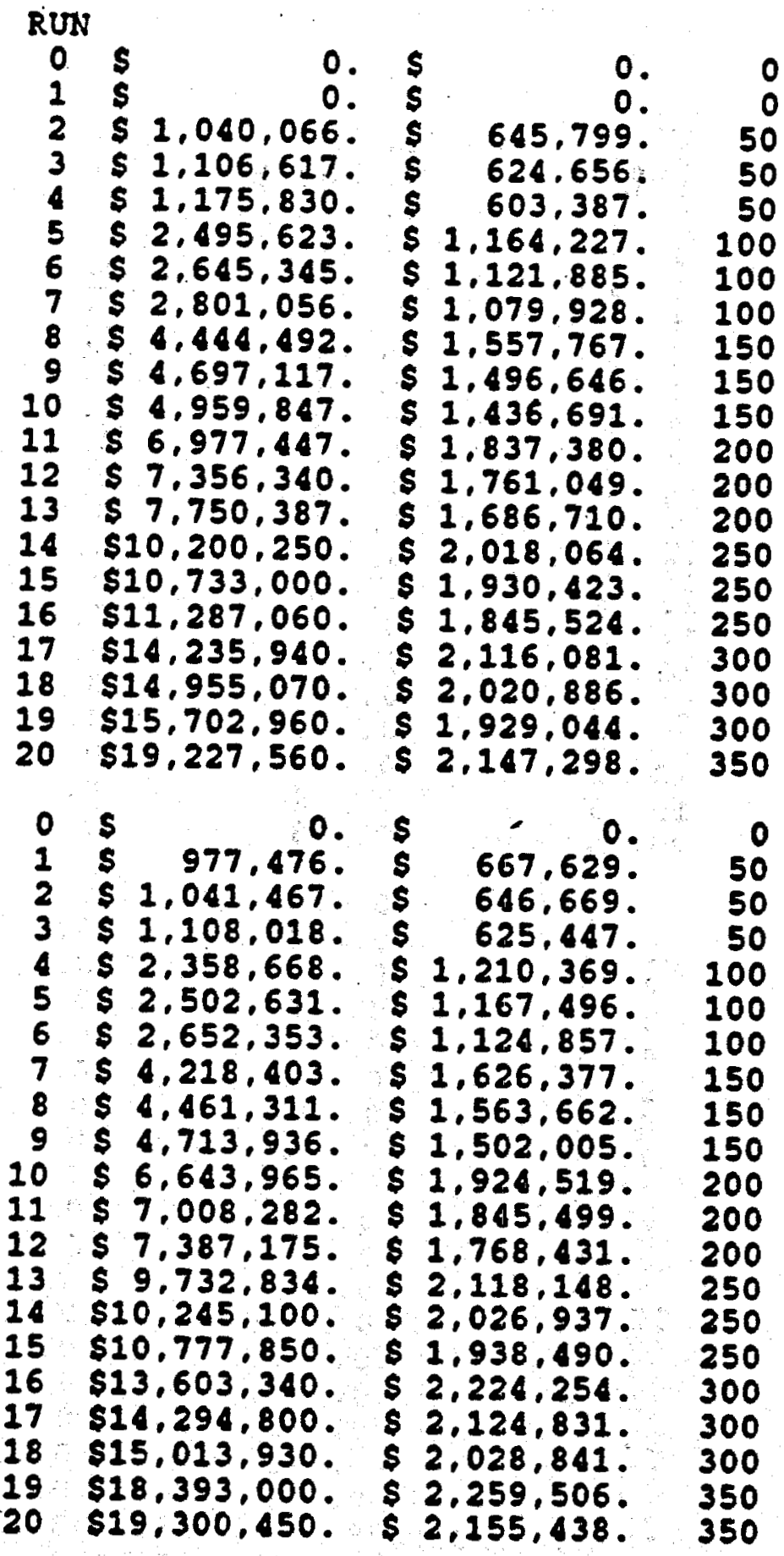

1987 NET PRESENT VALUE OF ROYALTIES

WITH RED W/O RED DIFEERENCE

$\$ 32,549,410, \$ 29,023,450, \$ 3,525,960$.

INSTALLED $\mathrm{MW}=350$

Ok 
VALE, OR

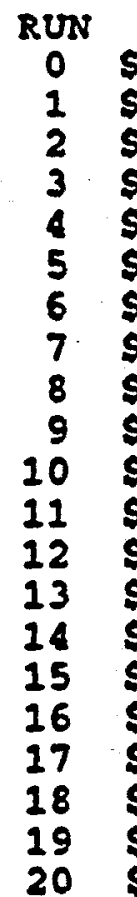

0.

0.

0

o. $\$$

0 . 5

o. $s$

o. s

o. 5

0.5

o. 5

o. S

o. $\$$

o. S

o. $\$$

o. S

o. $\$$

o. 5

o. $\$$

o. S

o. S

o. S

o. \$

o. $\$$

0. 0

o. $\quad 0$

o. 0

$0 . \quad 0$

$0 . \quad 0$

o. $\quad 0$

o. 0

$0 . \cdots$

$0 . \quad 0$

$0 . \quad 0$

o. $\quad 0$

$0 . \cdots \quad 0$

0.0

0. 0

o. 0

o. 0

0. $\quad 0$

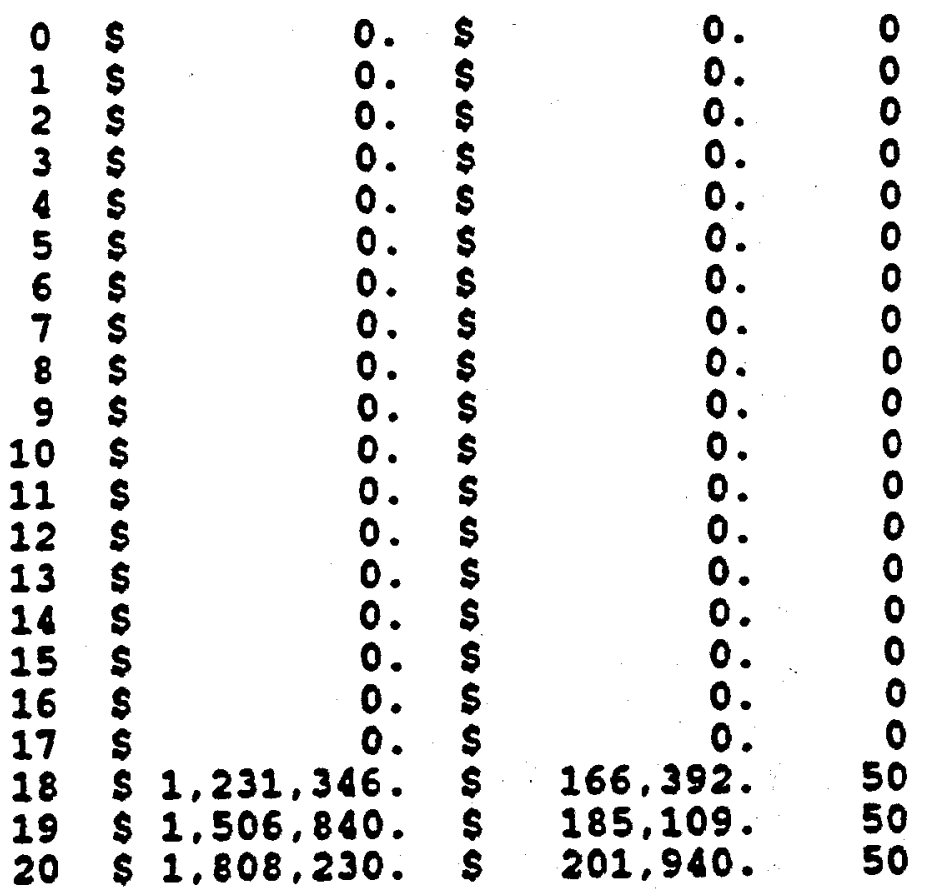

1987 NET PRESENT VALUE OE ROYALTIES

WITH RED W/O RED DIFFERENCE

$\$ 553.441 . \quad \$ 0 . \quad \$ 553,441$.

INSTALLED MH $=50$

Ok 
RESULTS ASSUAING \$O.01/KH-HR TRANSHISSTION COSTS

$G-29 / G-30$ 


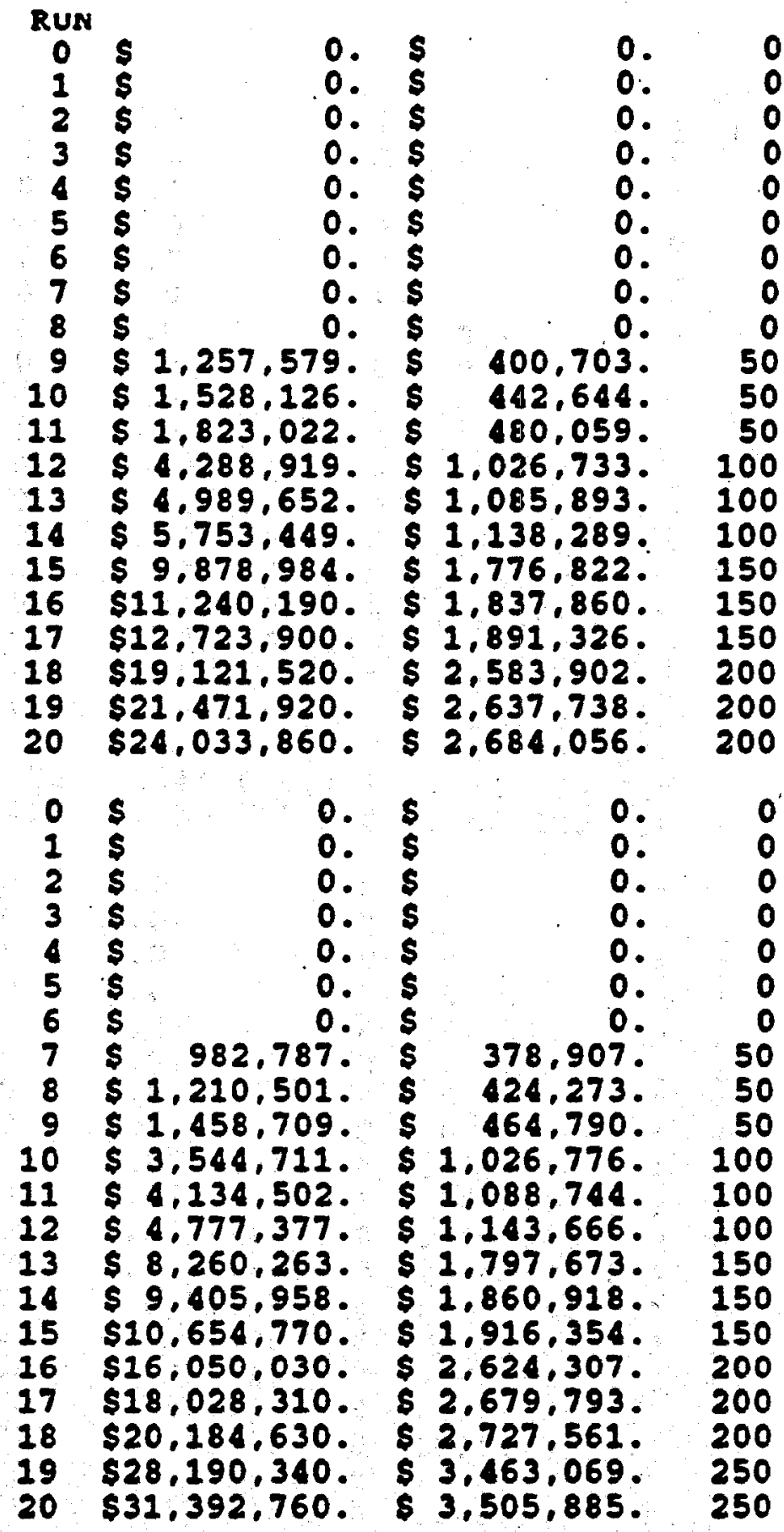

1987 NET PRESENT VALUE OF ROYALTIES

WITH RED W/O RED DIFFERENCE

$\$ 25,102,710 . \$ 17,986,020, \$ 7,116,688$.

INSTALLED MW $=250$

Ok 


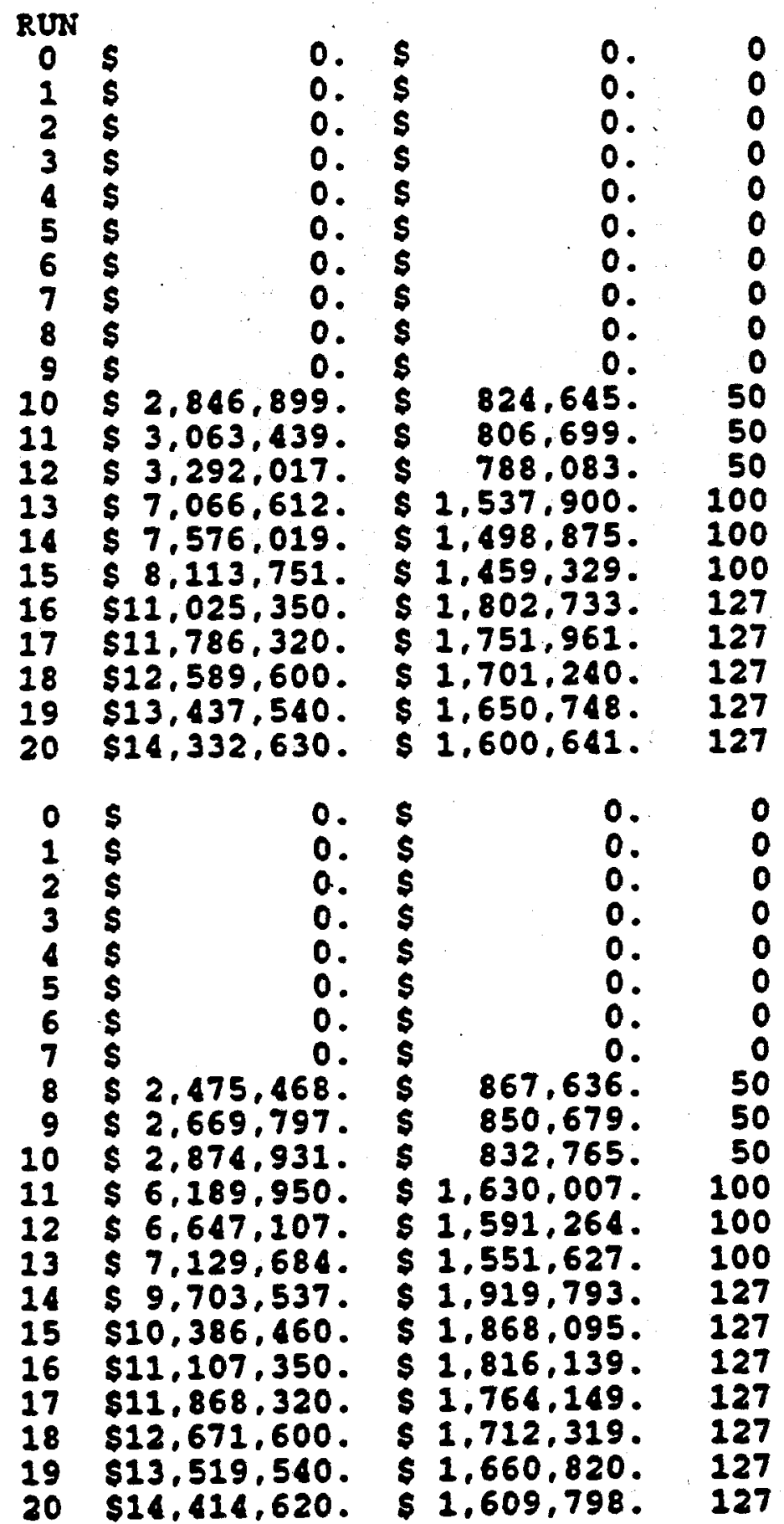

1987 NET PRESENT VALUE OF ROYALTIES

WITH RED W/O RED DIFEERENCE

$\$ 19,675,090$. $\$ 15,422,850$. \$4,252,237.

INSTALLED MW $=127$

Ok 
LAKE CITY - SURPRISE VALLEY, CA

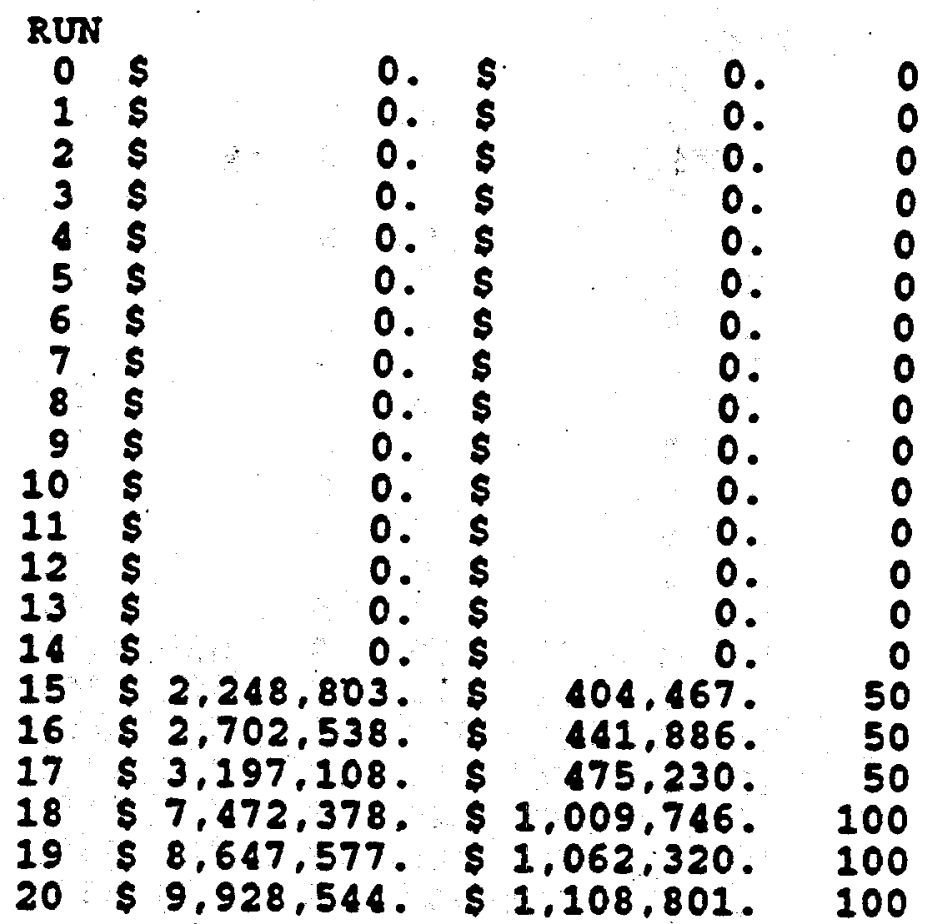

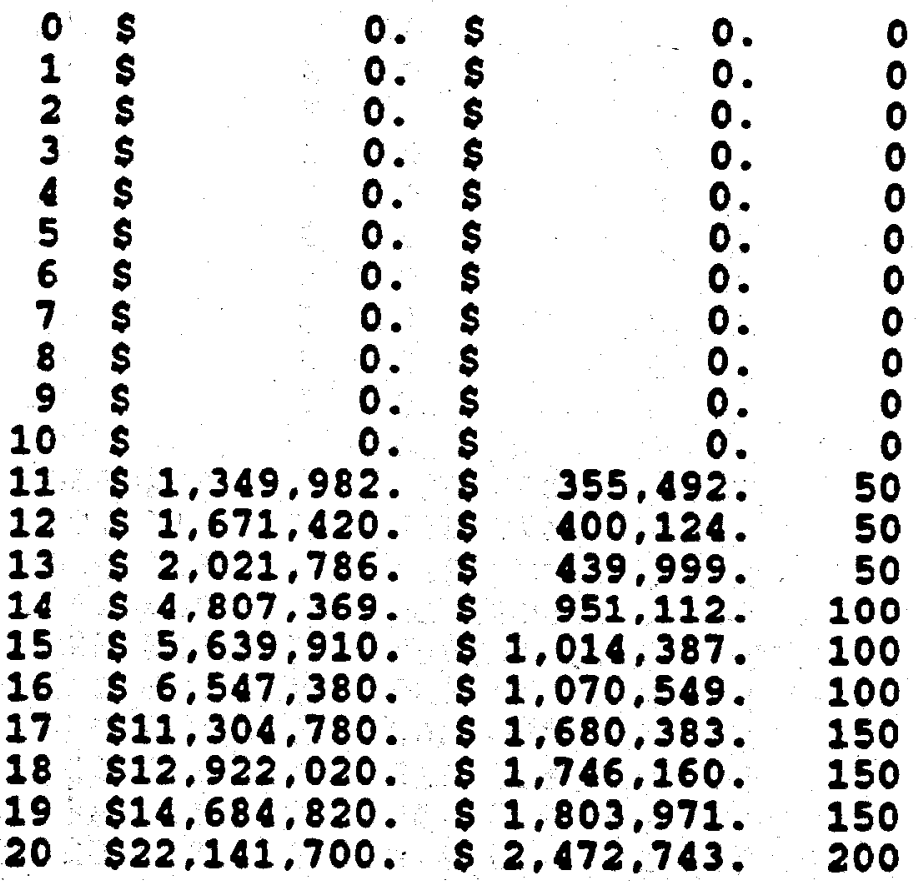

1987 NET PRESENT VALUE OF ROYALTIES

WITH RED W/O RED DIFFERENCE

$\$ 11,934,920 . \$ 4,502,450 \quad \$ 7,432,472$.

INSTALLED MW $=200$

Ok 
GLASS MT., CA

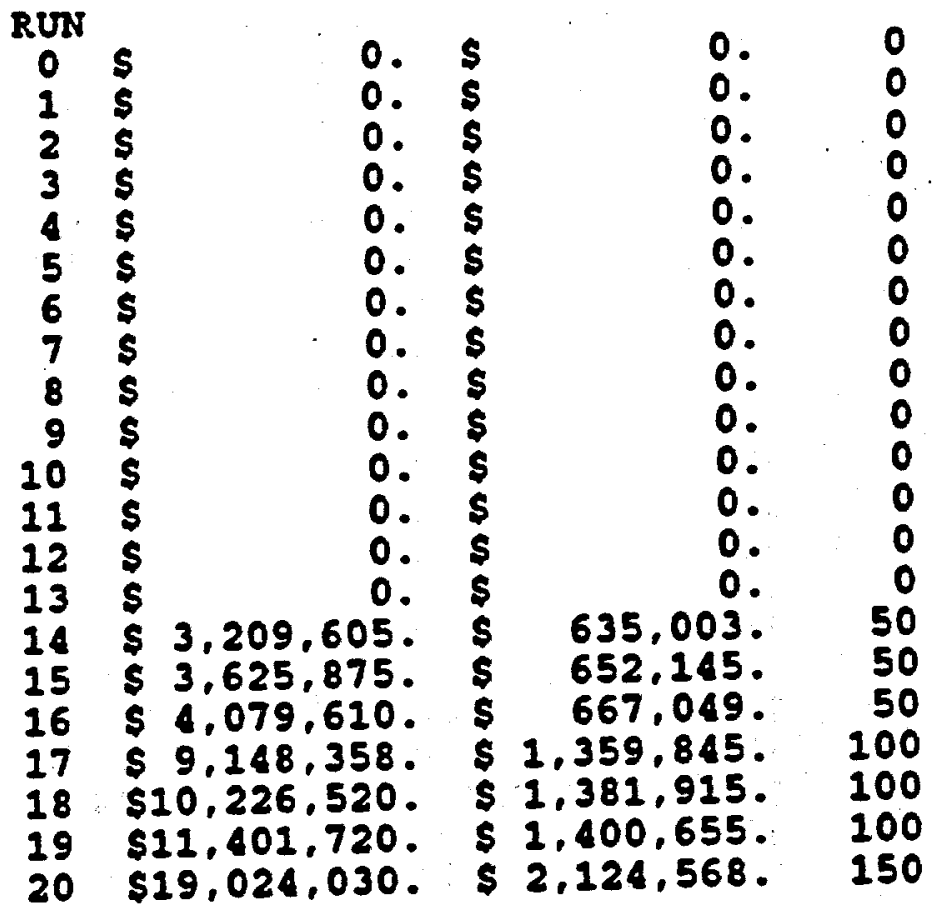

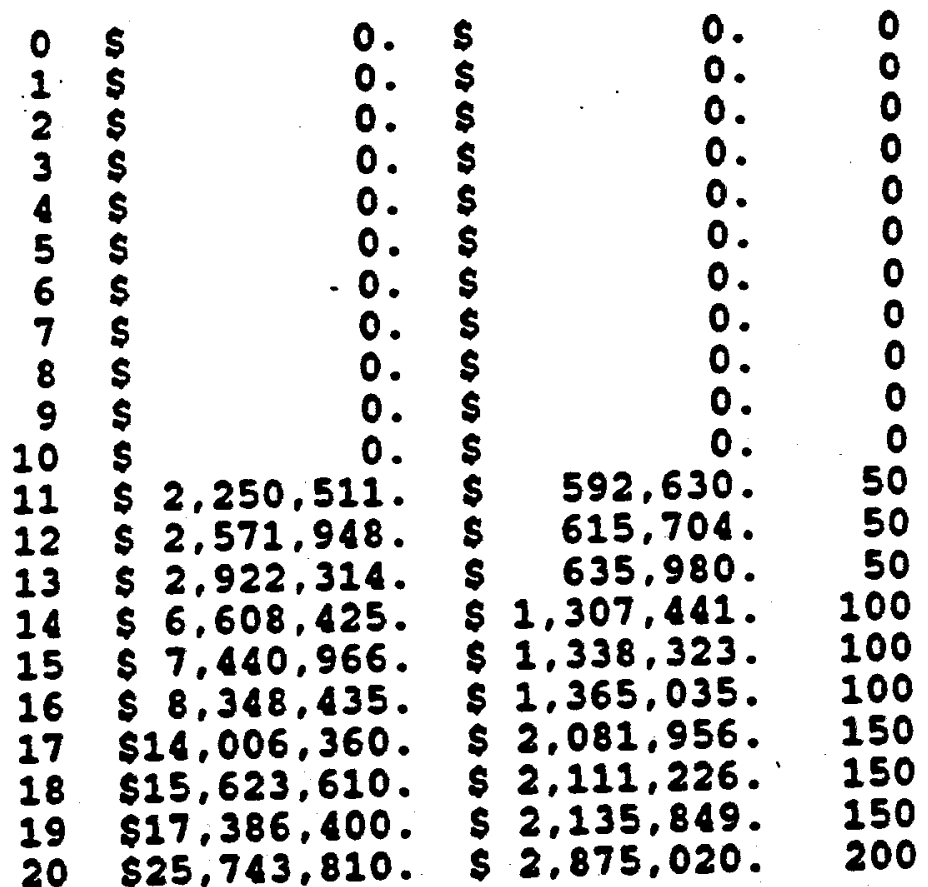

1987 NET PRESENT VALUE OF ROYALTIES

HITH RED W/O RED
$\$ 15,059,160 . \$ 8,221.180, \$ 6.837 .985$.
INSTALLED MH $=200$
OK


MONO-LONG VALLEY, CA

\begin{tabular}{|c|c|c|c|c|c|}
\hline \multicolumn{6}{|c|}{$\begin{array}{r} \\
580,5 \\
601,2 \\
619,40\end{array}$} \\
\hline $\begin{array}{l}0 \\
1 \\
2 \\
3 \\
4 \\
5 \\
6 \\
7 \\
8 \\
9 \\
10 \\
11 \\
12 \\
13 \\
14 \\
15 \\
16 \\
17 \\
18 \\
19\end{array}$ & 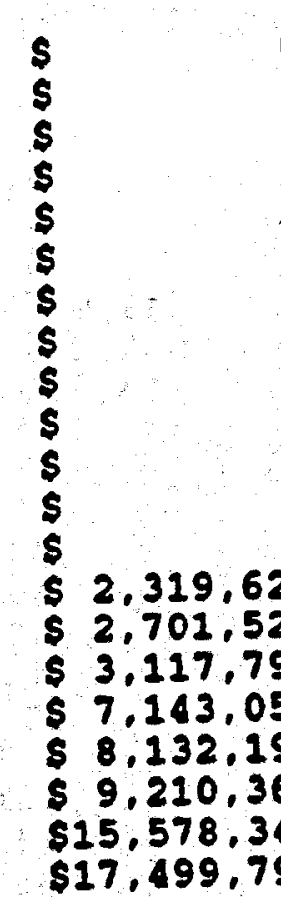 & $\begin{array}{l}0 . \\
0 . \\
0 . \\
0 . \\
0 . \\
0 . \\
0 . \\
0 . \\
0 . \\
0 . \\
0 . \\
0 . \\
0 . \\
26 . \\
95 . \\
59 . \\
00\end{array}$ & 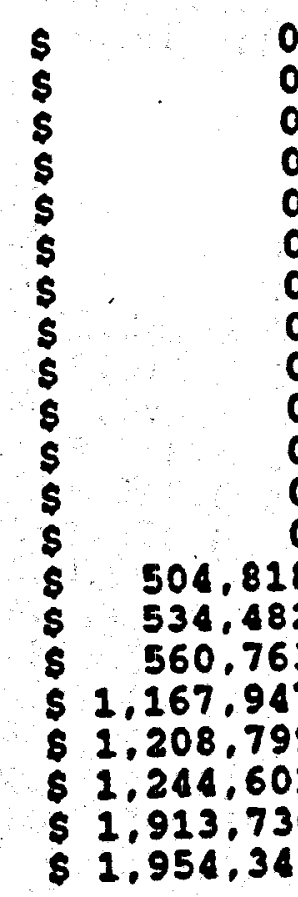 & $\begin{array}{l}0 . \\
0 . \\
0 . \\
0 . \\
0 . \\
0 . \\
0 . \\
0 . \\
0 . \\
0 . \\
0 . \\
0 . \\
0 . \\
18 . \\
32 . \\
53 . \\
17 . \\
99 . \\
02 . \\
36 . \\
44 .\end{array}$ & $\begin{array}{r}50 \\
50 \\
50 \\
100 \\
100 \\
100 \\
150 \\
150\end{array}$ \\
\hline
\end{tabular}

1987 NET PRESENT VALUE OF ROYALTIES

WITH RED W/O RED DIFFERENCE

$\$ 9,089,490$. \$4,370,129, \$4,719,362.

INSTALLED WW $=150$

Ok 


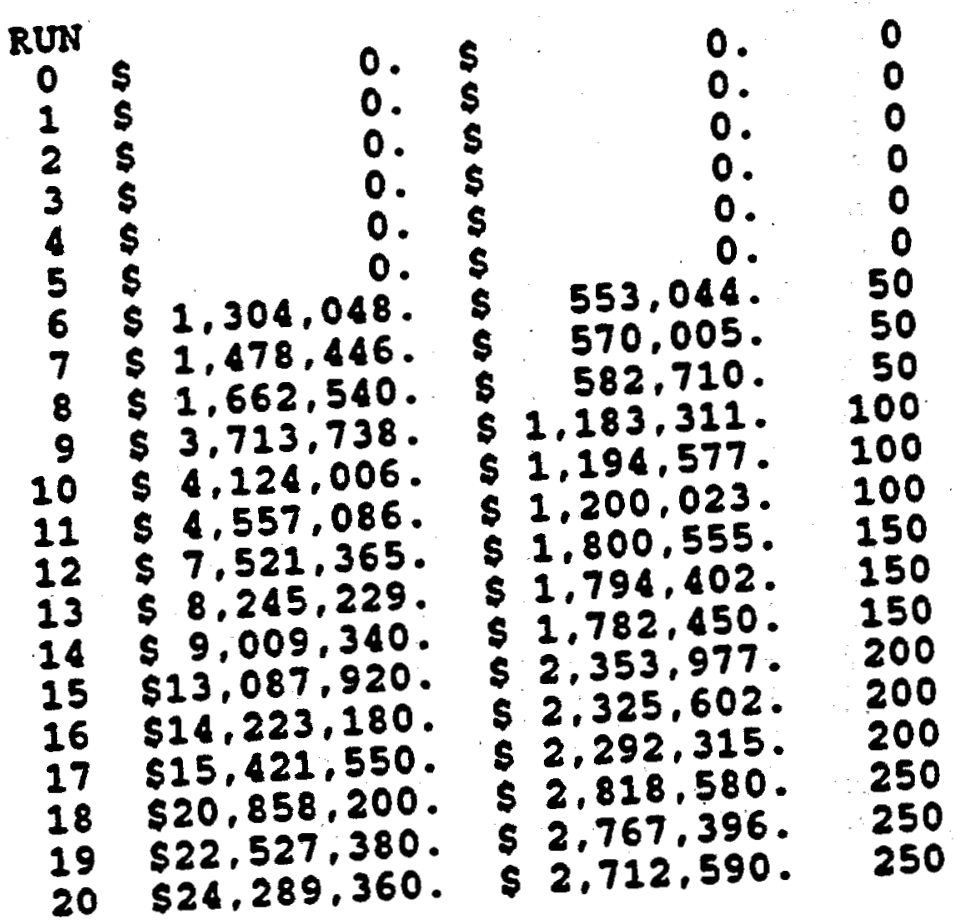

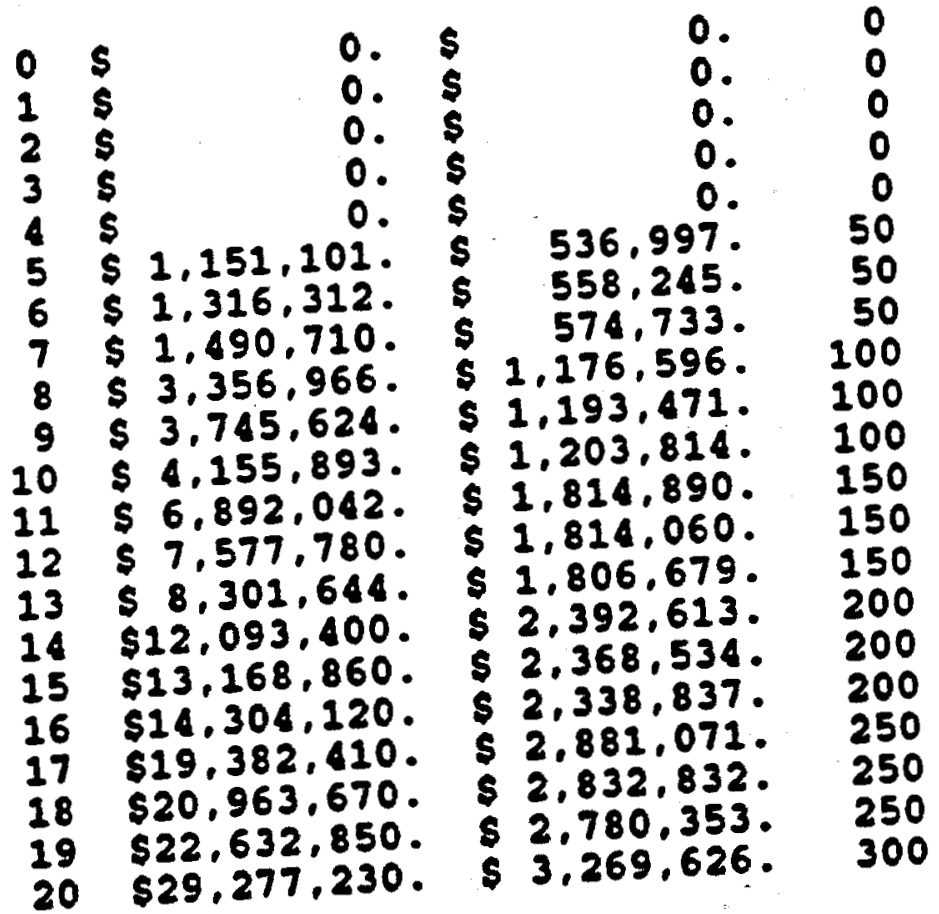

1987 NET RRESENT VALUE OF ROYALTIES

WITH RED H/O RED DIFFERENCE

$\$ 29,543,350 . \$ 25,931,540$ — $\$ 3,611,818$.

INSTALLED MH $=300$

Ok 


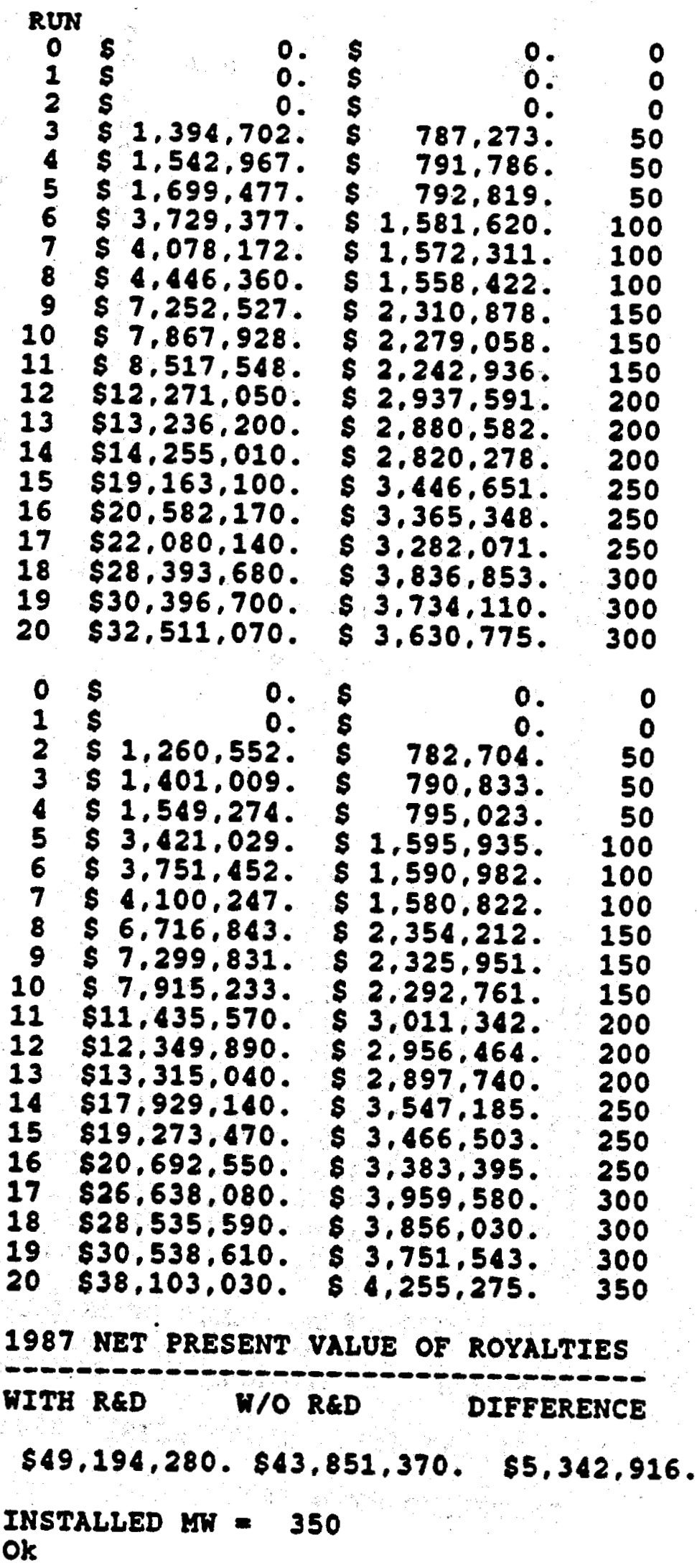




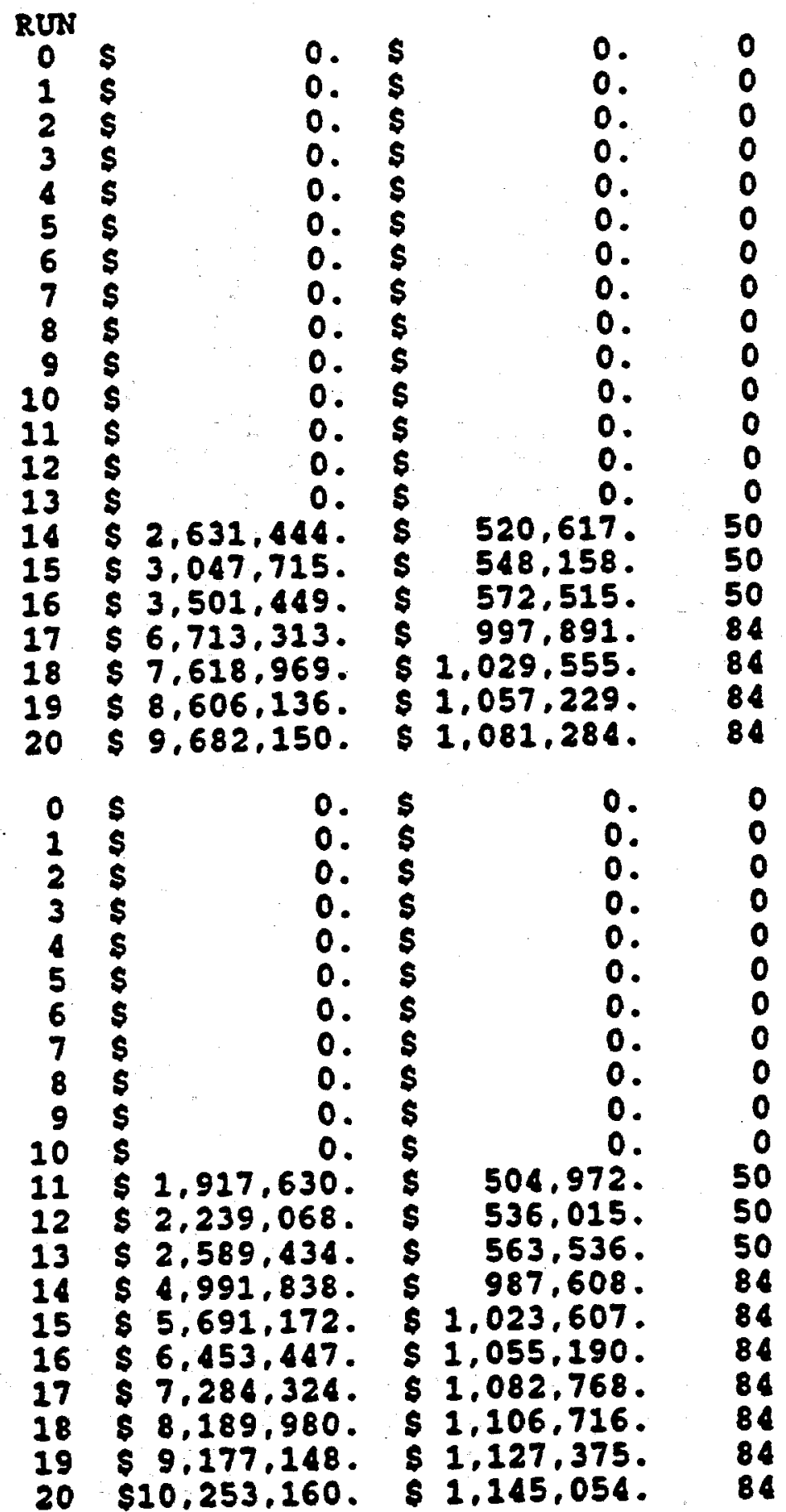

1987 NET PRESENT VALUE OF ROYALTIES

WITH RED W/O RED DIFERENCE
$\$ 9,132,841 . \$ 5,807,249 . \$ 3,325,592$.
INSTALLED MH $=84$


COSO, CA

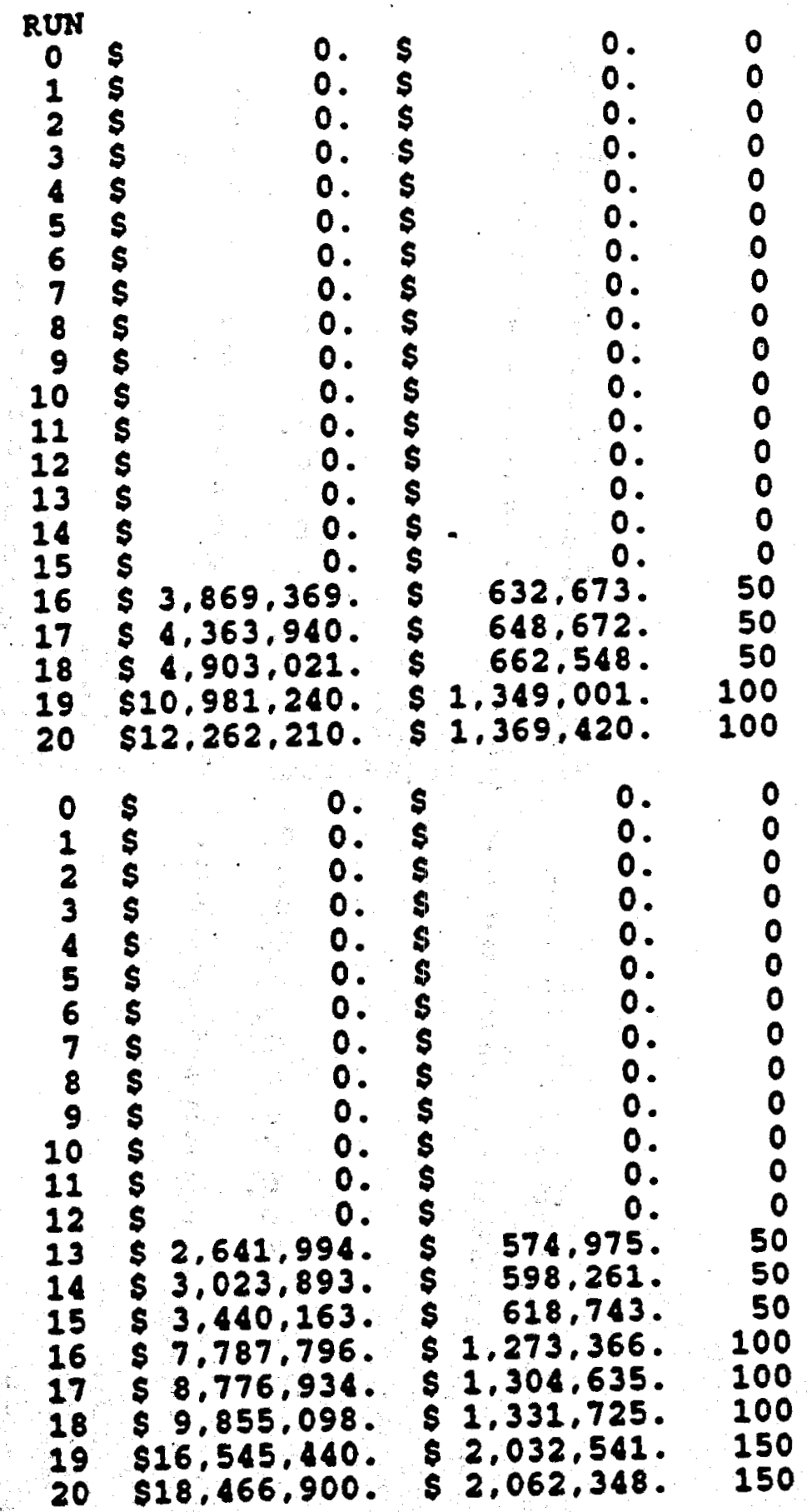

1987 NET PRESENT VALUE OE ROYALTIES

WITH RED W/O RED DIFEERENCE

$\$ 9,796,593$. \$4,662,313. \$5,134,280.

INSTALLED MN $=150$

Ok 


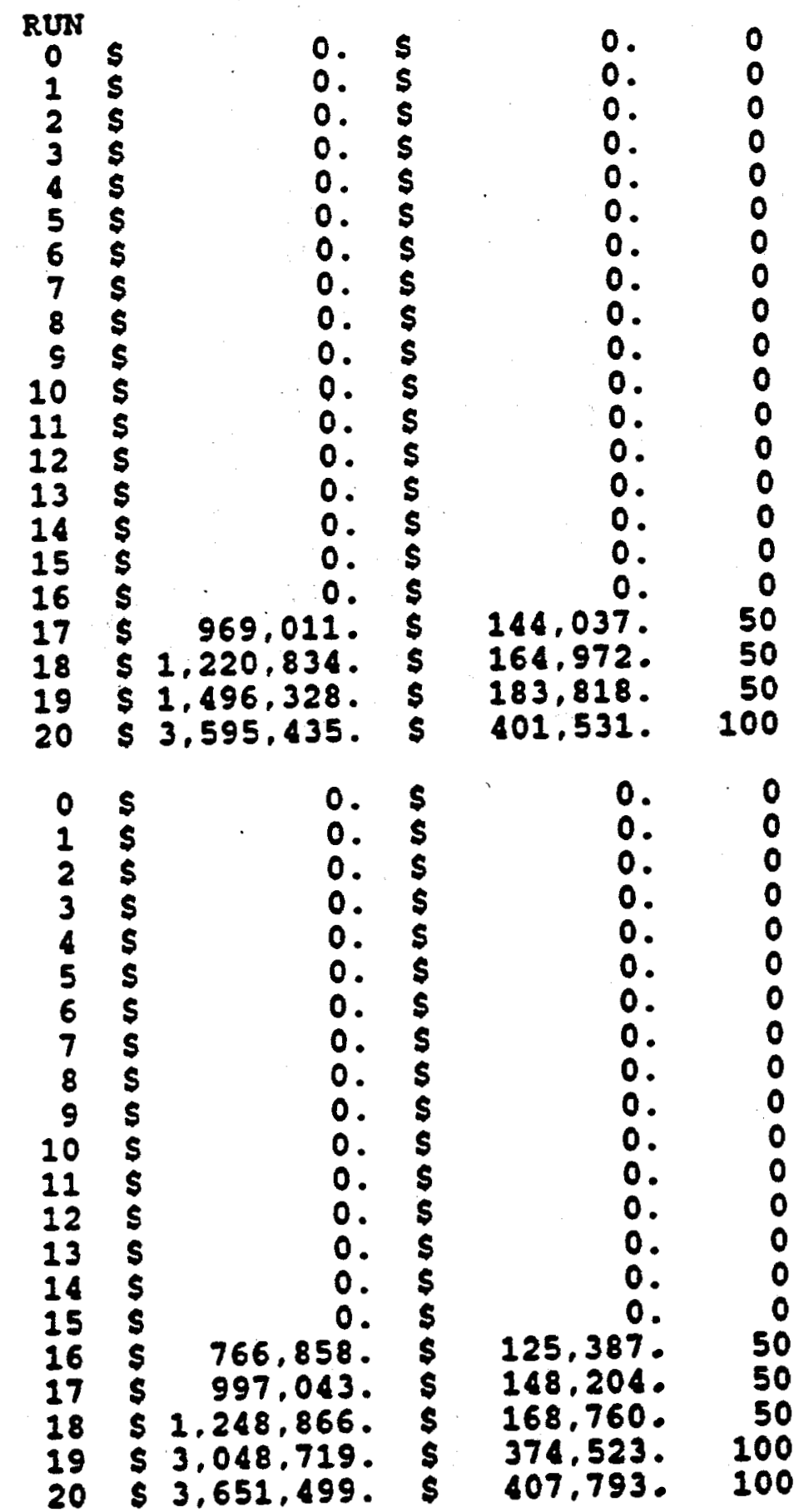

1987 NET PRESENT VALUE OE ROYALTIES

WITH RED W/O RED DIFEERENCE
$\$ 1,224,667$.
INSTALLED MH $=$
OK




\section{DIXIE VALLEY, NV}

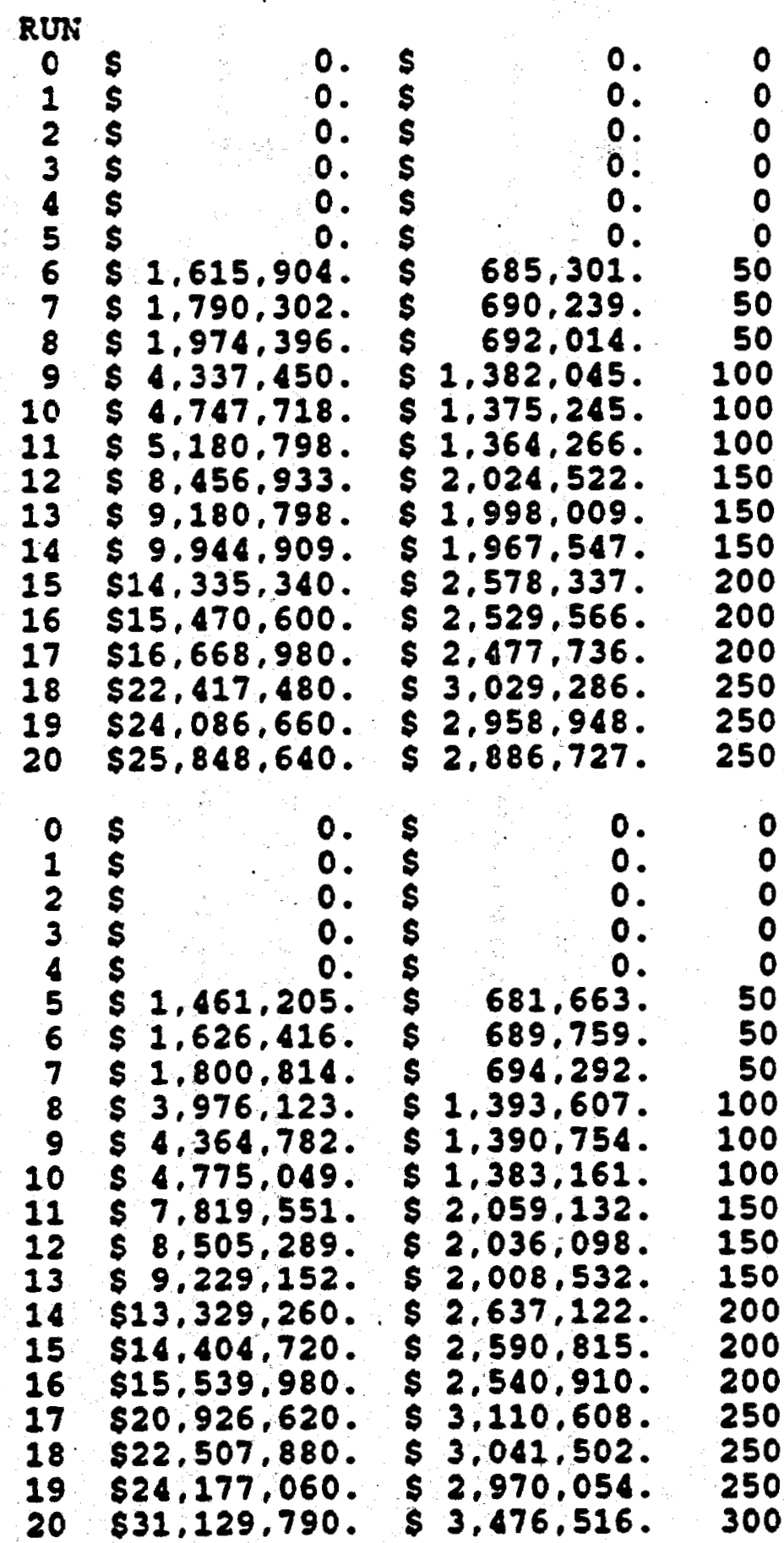

1987 NET PRESENT VALUE OF ROYALTIES

WITH RED W/O RED DIFFERENCE

$\$ 32,704,520, \$ 28,639,790 . \$ 4,064,736$.

INSTALLED MW $=300$

Ok 


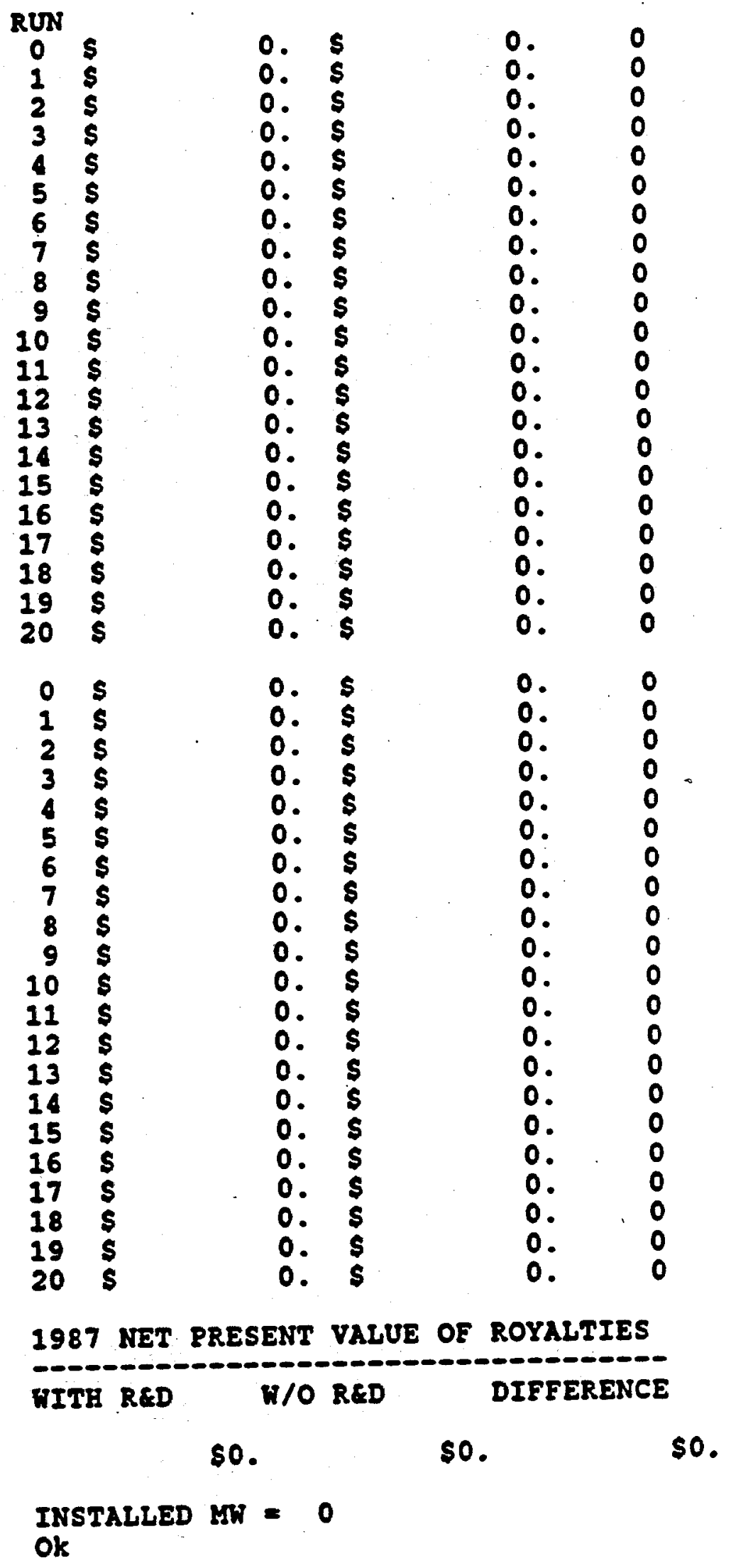




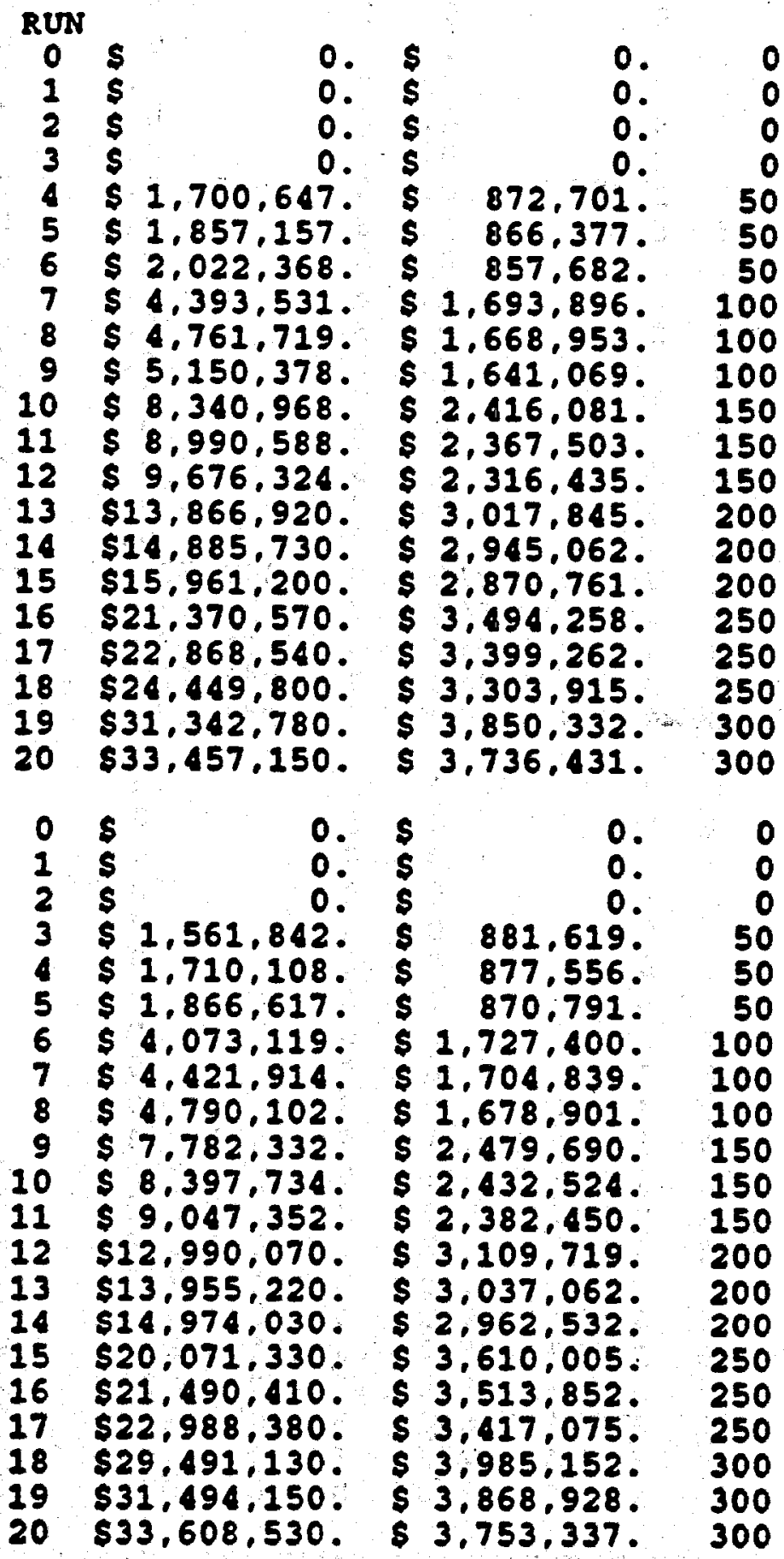

1987 NET PRESENT VALUE OF ROYALTIES

WITH RED W/O RED DIFFERENCE

$\$ 46,293,430, \$ 41,318,560, \$ 4,974,868$.

INSTALLED MH $=300$ Ok 


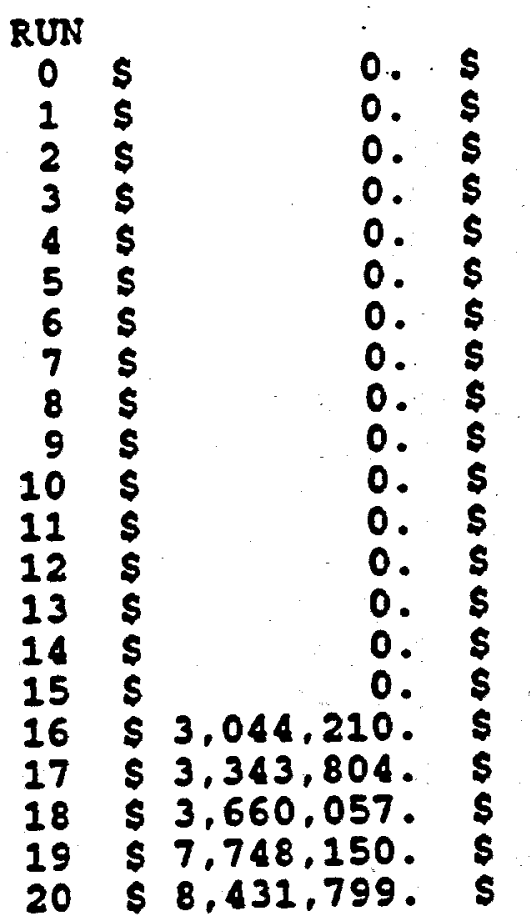

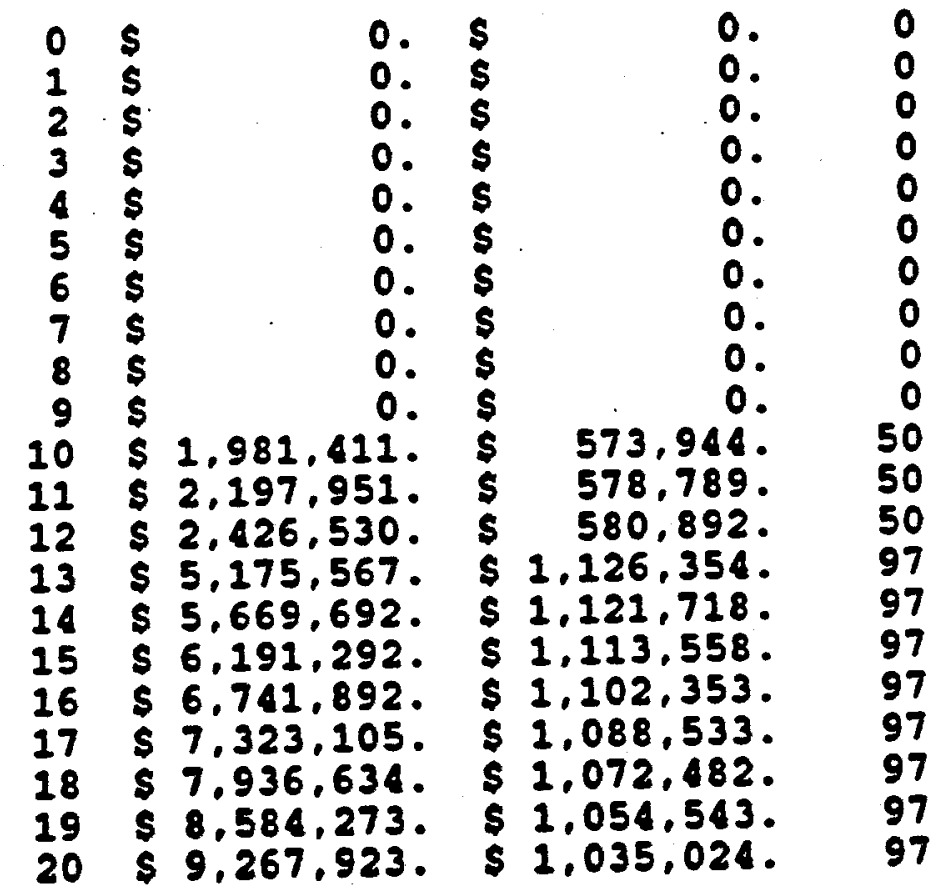

1987 NET PRESENT VALUE OF ROYALTIES

NITH RED H/O RED DIFFERENCE

$\$ 10,448,190 . \quad \$ 3,382,849 . \quad \$ 7,065,340$.

INSTALLED MH $=97$

Ok 


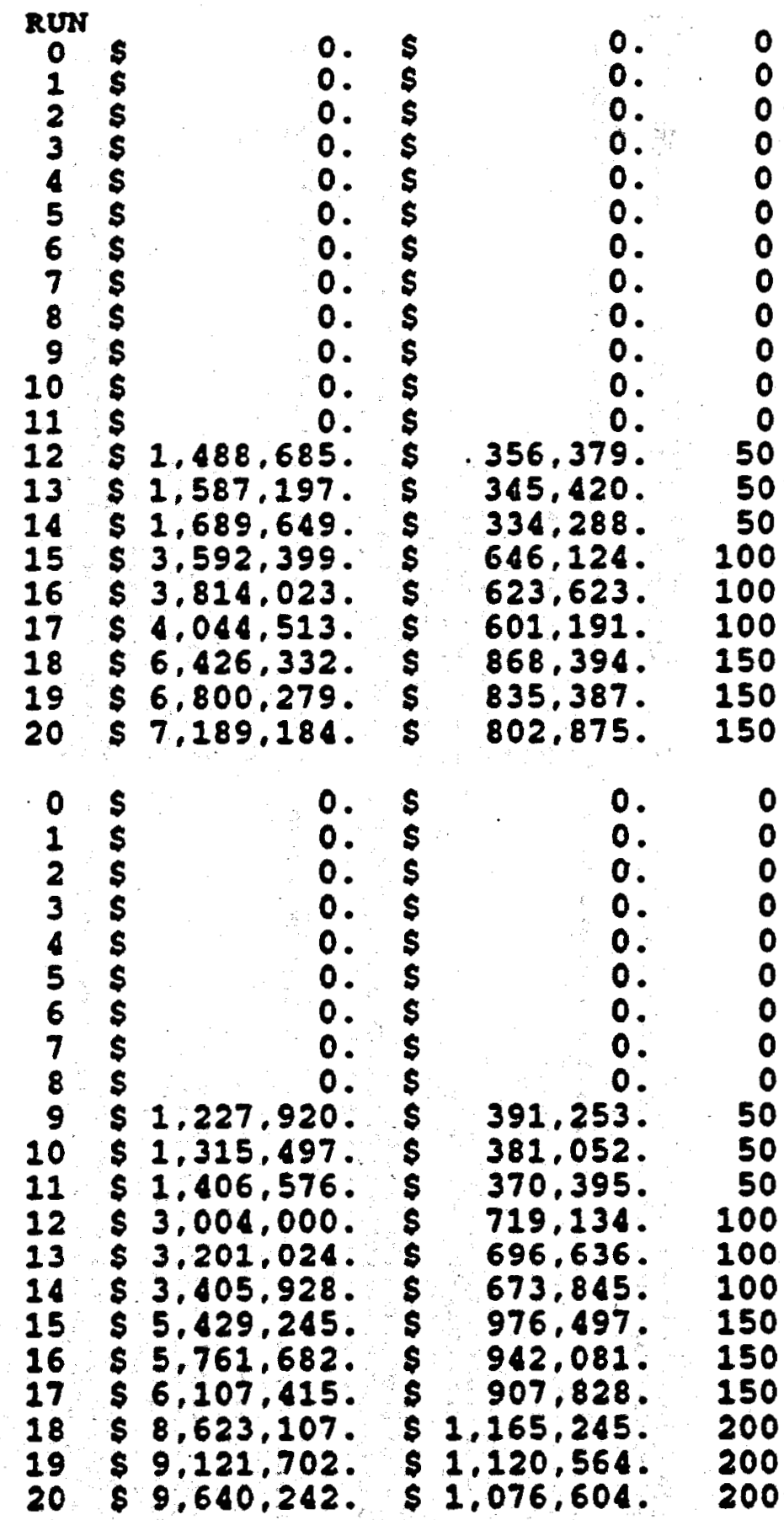

1987 NET PRESENT VALUE OF ROYALTIES

WITH RED W/O RED DIFFERENCE

$\$ 9,421,134 . \$ 5,413,681$. \$4,007,454.

INSTALLED $\mathrm{NW}=200$

OK 
RUN

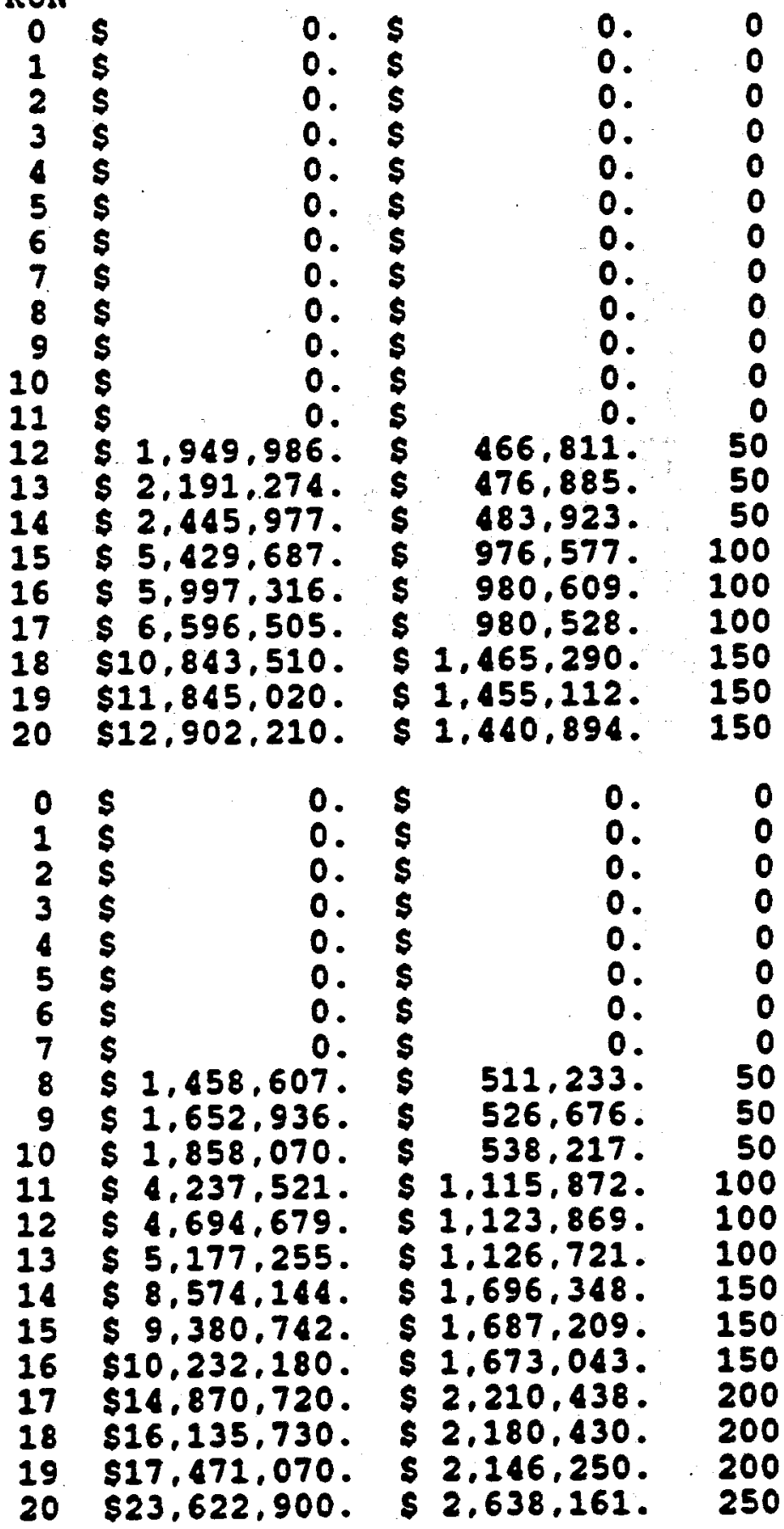

1987 NET PRESENT VALUE OF ROYALTIES

WITH RED W/O RED DIFEERENCE

$\$ 19,174,460 . \quad \$ 8,726,629 . \$ 10,447,840$.

INSTALLED MH $=250$

Ok 


\section{RUN}

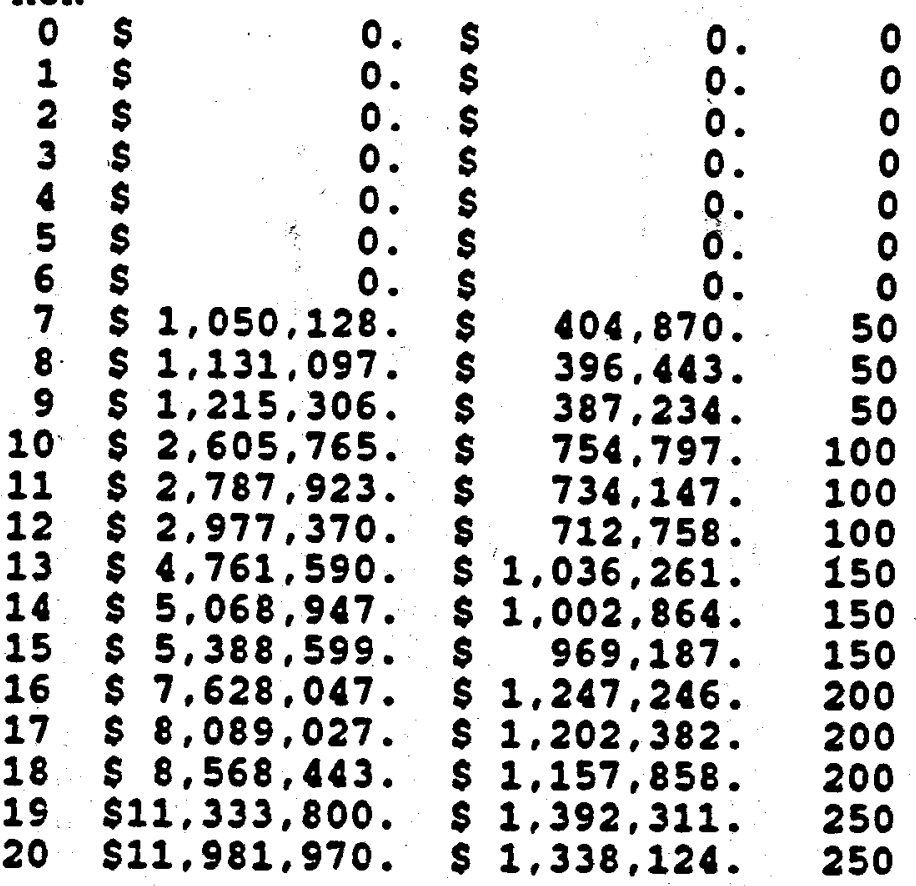

0 s

1.5

0. $\$$

0. $\$$

$0 . \quad 0$

2 S

$0 . \$$

$3.5 \quad 0.5$

$4 \$ 20 . \$$

5 \$ $904.420 . \$$

$6 \$ 979.280$. $\$$

$7 \$ 1,057,136 . \$$

8. $\$ 2,280,415$. $\$$

$9 \$ 2,448,832 . \$$

$10 \$ 2,623,986$. S

421.918 .50

$415,310 . \quad 50$

$407,571 . \quad 50$

799.272. $\quad 100$

$780.273 . \quad 100$

$760.075 . \quad 100$

11 \$ $4.214,122 . \$ 1,109,710 . \quad 150$

$12 \$ 4,498,291 . \$ 1.076,855 . \$ 150$

$13 \$ 4.793 .827, \$ 1,043,276 \ldots 150$

14.\$ $6,804,849, \$ 1,346,303.200$

$15 \$ 7.231 .051, \$ 1,300,568, \quad 200$

$16 \$ 7,674,300, \$ 1,254,809$ \& 200

$17 \$ 10,171,550, \$ 1,511,936,250$

$18 \quad \$ 10,770.820 \ldots \$ 1.455 .467 . \quad 250$

$19811,394,070$. \$ $1,399,715.250$

$20 \$ 14,452,650$ \& $1,614,045.300$

1987 NET PRESENT VALUE OF ROYALTIES

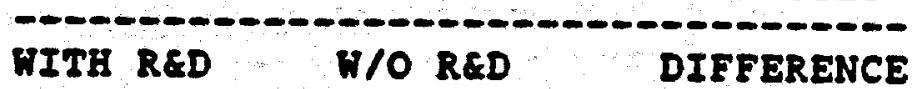

$\$ 16,697,100, \$ 12,736,480, \$ 3,960,624$.

INSTALLED MH $=300$

Ok 
VALE, OR

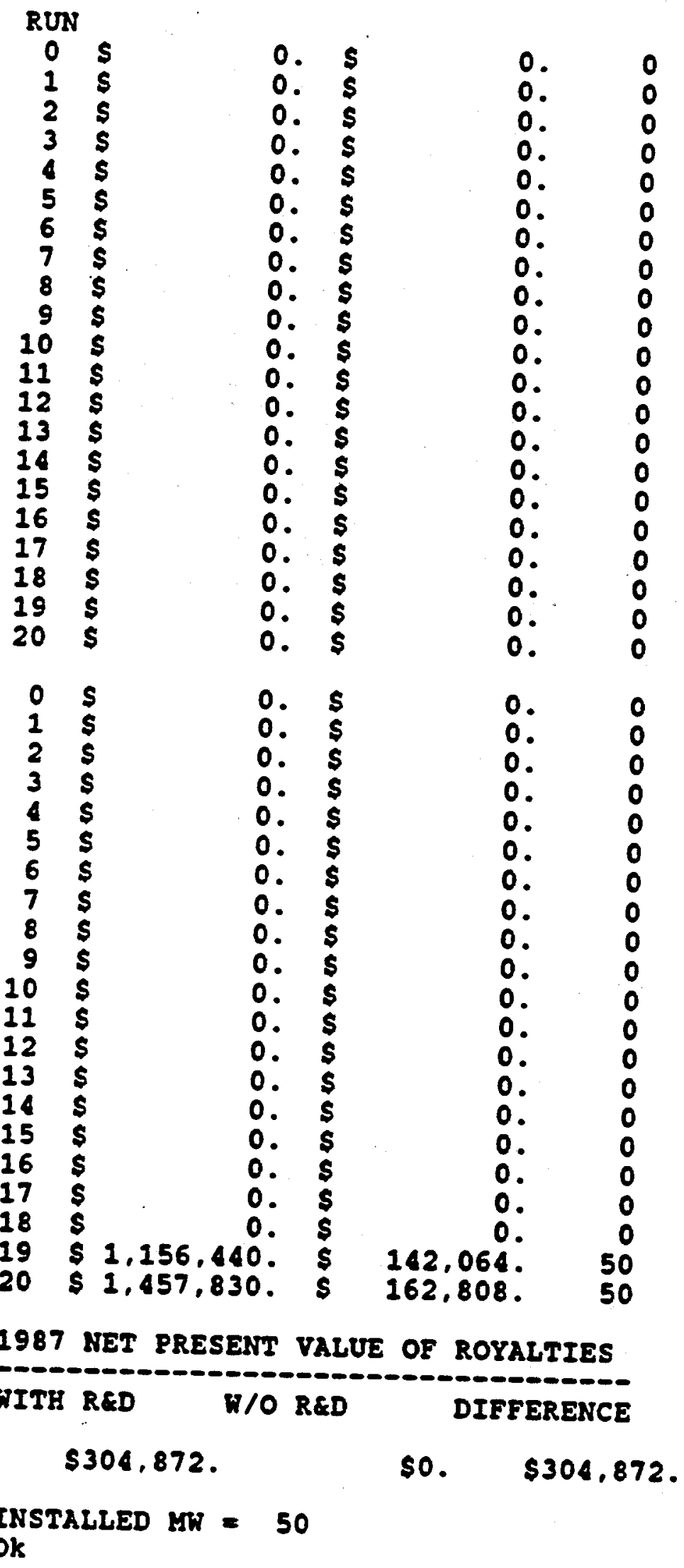

